\title{
FABRICATION AND INSPECTION
}

\section{OF A 30 MEGAWATT PROTOTYPE}

STEAM GENERATOR FOR SODIUM

\section{COOLED REACTOR SYSTEMS}

Submitted to

The United States

Atomic Energy Commission

Chicago Operations Office

Under Contract AT(11-1)-1213
PATENT CLEARANCE OBTAINEQ. REEEASE TO

THE PUBLIC IS APPROVED. PROBEDURES

ARE ON FLLE IN THE RECEIVIN SESCWOR,
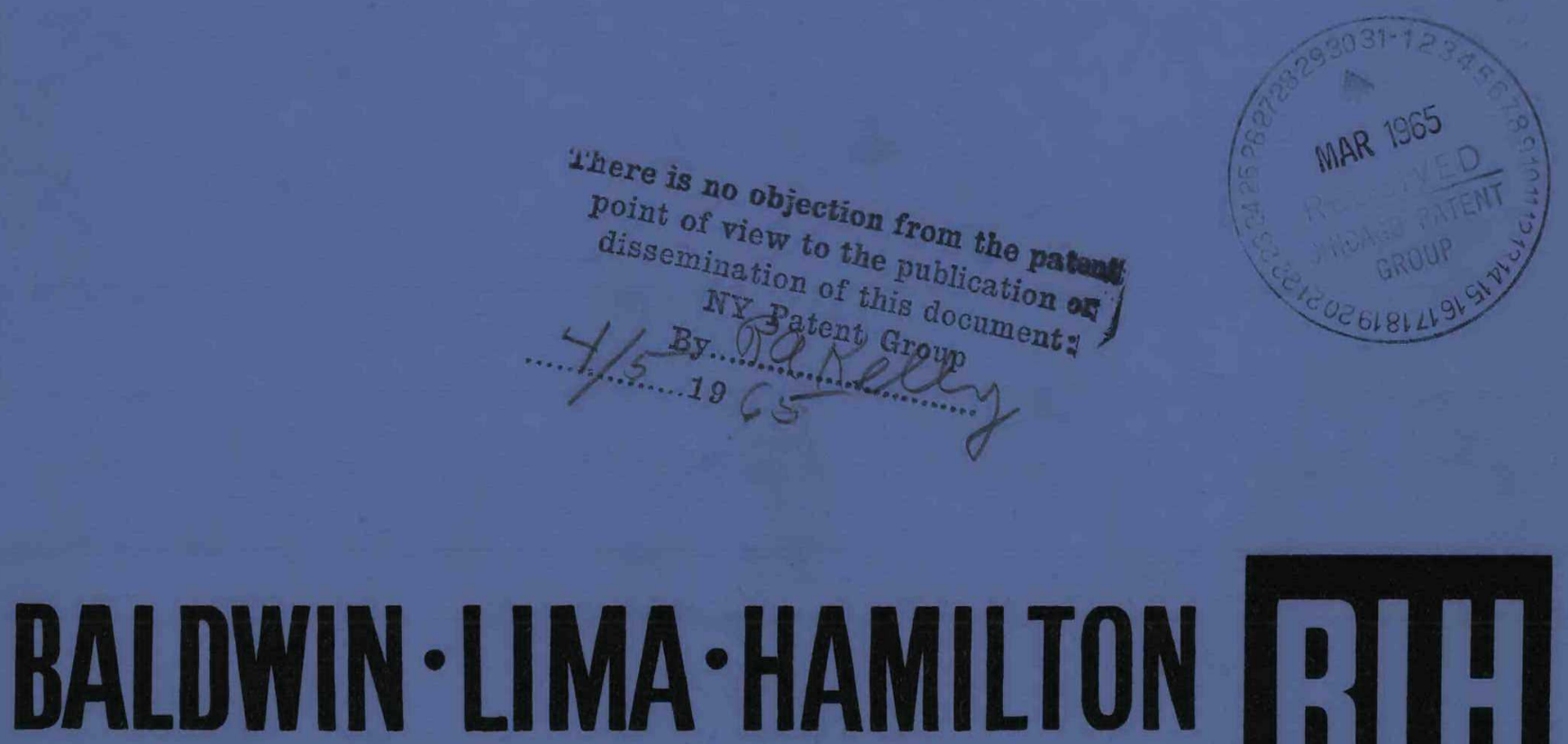

$\cdot$ HAM Industrial Equipment Division

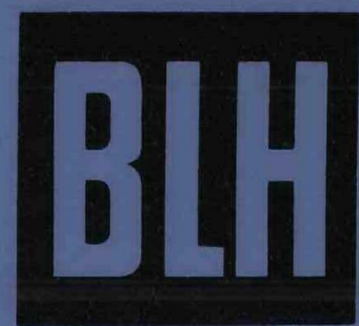




\section{DISCLAIMER}

This report was prepared as an account of work sponsored by an agency of the United States Government. Neither the United States Government nor any agency Thereof, nor any of their employees, makes any warranty, express or implied, or assumes any legal liability or responsibility for the accuracy, completeness, or usefulness of any information, apparatus, product, or process disclosed, or represents that its use would not infringe privately owned rights. Reference herein to any specific commercial product, process, or service by trade name, trademark, manufacturer, or otherwise does not necessarily constitute or imply its endorsement, recommendation, or favoring by the United States Government or any agency thereof. The views and opinions of authors expressed herein do not necessarily state or reflect those of the United States Government or any agency thereof. 


\section{DISCLAIMER}

Portions of this document may be illegible in electronic image products. Images are produced from the best available original document. 


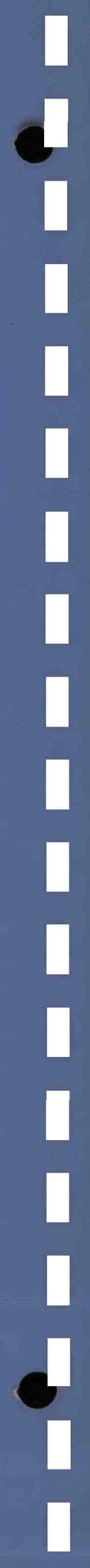


Fabrication and Inspection of A 30 Megawatt Steam Generator Prototype For Sodium Cooled Reactor Systems

\author{
Submitted To \\ United States Atomic Energy Commission \\ ChIcago Operations office \\ 9800 South Cass Avenue \\ Argonne, Illinols \\ Under \\ Contract AT(11-1)-1213 \\ November 1, 1964
}

Baldwin-Iima-Hamilton Corporation

Industrial Equipment Division

Eddystone, Pennsylvania 
AEC LEGAL NOTICE

Th1s report was prepared as an account of Government sponsored work. NeIther the United States, nor the Commission, nor any person acting on behalf of the Commission:

A. Makes any warranty or representation, expressed or implied, with respect to the accuracy, completeness, or usefulness of the information contained in this report, or that the use of any information, apparatus, method, or process disclosed in this report may not infringe privately owned rights.

B. Assumes any liabilities with respect to the use of, or for damages resulting from the use of any information, apparatus, method, or process disclosed in this report.

As used in the above, "person acting on behalf of the Commission" includes any employee or contractor of the Commission, or employee of such contractor, to the extent that such employee or contractor of the Commission, or employee of such contractor prepares, disseminates, or provides access to, any information pursuant to his employment or contract with the Commission, or his employment with such contractor.

\section{BALDWIN-IIMA-HAMILTON IEGAL NOTICE}

This report was prepared by Baldwin-Lima-Hamilton Corporation in the course of work under, or in connection with, Contract No. AT(11-1) 1213, issued by U. S. Atomic Energy Commission, COO and subject only to the rights of the United states, under the provisions of this contract, Baldwin-Lima-Hamilton makes no warranty or representation, express or lmplied, and shall have no liablilty with respect to this report or any of 1 ts contents or with respect to the use thereof or w1th respect to whether any such use will infringe the rights of others. 


\section{DISTRIBUTION LIST}

FOR REPORT CO0-1213-26

PREPARED UNDER CONTRACT NO. AT (11-1)-1213

BALDWIN-LIMA-HAMILTON CORPORATION

Number of Copies

Required

10

2

3

1

1

1

1

1

1

1

3

1

Fred C. Mattmueller, Director, Contracts Division

U.S. Atomic Energy Commission, Argonne, III. 60439

C. A. Pursel, Director, Reactor Engineering Division

U.S. Atomic Energy Commission, Argonne, III. 60439

G. W. Wensch, Chlef, LIquid Metal Cooled Reactors Branch, Div. of Reactor Development \& Technology U.S. Atomic Energy Commission, Washington, D.C. 20545

C. W. R1chards, Canoga Park Area Office

U.S. Atomic Energy Commission, Canoga Park, Cal1f.

J.P. Holliday, San Franc1sco Openations Off1ce

2111 Bancroft Way, Berkeley, Callfornia 94704

O. E. Dwyer, Brookhaven National Laboratory Upton, L.I., New York

H. W. Savage, Oak Ridge National Laboratory

P. O. Box X, Oak RIdge, Tennessee

W. R. Simmons, Argonne National Laboratory

9700 South Cass Avenue, Argonne, IIIInols

W. R. Wykofit, Los Alamos Sclentific Iaboratory

P. 0. Box 1663, Los Alamos, New Mexico

Jules Wise, New York Operations office

New York, New York

D. T. Eggen, Atomics International, A D1v. of North American Aviation, Inc., P.O. Box 309, Canoga Park, California

P. B. Probert, The Babcock and Wilcox Company Barberton, Ohio 
Number of Copies Required

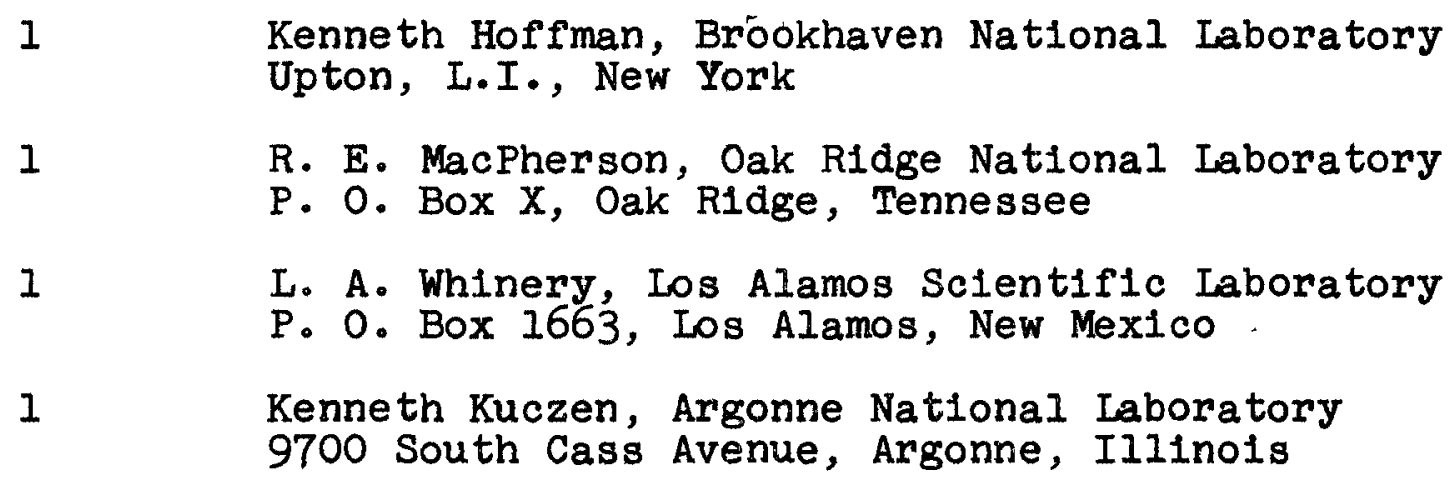

111 
REPORT CO0-1213-26

TABLE OF CONTENTS

Page

SECTION 1 - SUMMARY

1

Introduction 1-1-1

Conclusion

$1-2-1$

SECTION 2 - FABRICATION OF PARTS AND SUBASSEMBLIES

2

Shell and Shell Nozzles

2-1-1

Impact Shroud and Thermal Shields

$2-2-1$

Baffles

Thermal Shield Plates

2-3-1

Guide Rings

Tube Sheets

2-4-1

2-5-1

Heads and Head Nozzles

Thubes

Lower Shroud Assembly

2-6-1

2-7-1

2-8-1

2-9-1

SECTION 3 - ASSEMBLY

Tube Bundle

Tube Bundle into Shell

Upper Tube Sheet Assembly

Tube Sheet to Shell Attachment

Tube to Tube Sheet Attachment

Head to Tube Sheet Attachment

Thermocouples

Strain Gages

Preparation for Shipment

3-1-1

$3-2-1$

$3-3-1$

3-4-1

3-5-1

$3-6-1$

3-7-1

3-8-1

3-9-1

SECTION 4 - QUALITY CONTROL

4

Inconel Clad Test Procedure

Tube Sheet to Shell Weld Radiography

Head to Tube Sheet Radiography

Examination of Tubes at Guide Rings

Tube to Tube Sheet Weld Ieak Tests

Cleaning

Hydrostatic Tests

Drying

4-1-1

$4-2-1$

4-3-1

4-4-1

4-5-1

$4-6-1$

4-7-1

4-8-1

SECTION 5 - REPAIR PROCEDURES

5

Guide Ring Hole Relocation

Tube Hole in Tube Sheet Repair

Inconel Overlay in Head Repair

Thermocouple Wire Repair

Vacuum Oil Removal 
Page

SECTION 6 - WEIDING PROCEDURES

6

$6-1-1$

$6-1-2$

$6-1-3$

$6-1-4$

$6-1-5$

6-1-6

6-1-7

$6-1-8$

$6-1-9$

6-1-10

$6-1-11$

$6-1-12$

$6-1-13$

$6-1-14$

$6-1-15$

$6-1-16$

$6-1-17$

6-1-18

$6-1-19$

$6-1-20$

$6-1-21$

$6-1-22$

* Alternate submerged Arc Procedures

SECTION 7 - FABRICATION ASSEMBLY DRAWINGS

F-42207-1-1-E Outline and General Assembly 7-1-1

F-42207-1-2-F She II and Tube Sheet Detalls 7-1-2

F-42207-1-3-D Upper Channel Head Detalls

F-42207-1-4-F Baffle Assembly Detalis

F-42207-1-5-E Tubes - Layout, Welding and Bending

Details

F-42207-1-6-D Shielding Detalls

F-42207-1-9-B Iower Channel Head Deta11s

D-42207-1-21 Thermocouple Upper End W1ring Deta11

H-42207-1-22-C Instrument orientation, Complete

$7-1-3$

$7-1-4$

Material Data Sheet - 42207 Page 1

Material Data Sheet - 42207 Page 2

Material Data Sheet - 42207 Page 3

Material Data Sheet - 42207 Page 4

Material Data Sheet - 42207 Page 5

Material Data Sheet - 42207 Page 6

Material Data Sheet - 42207 Page 7

$7-1-5$

$7-1-6$

$7-1-7$

$7-1-8$

$7-1-9$

$7-2-1$

$7-2-2$

$7-2-3$

7-2-4

$7-2-5$

$7-2-6$

$7-2-7$

Materlal Data Sheet - 42207 Page 8

$7-2-8$ 
$\underline{\text { Page }}$

SECTION 8 - FABRICATION PHOTOGRAPHS

8

Upper End of Shell Inside

Upper End of Shell Showing Guide Iugs

8-1-1

Sine Wave Tube Bends Before Bend

$8-1-2$

Sine Wave Tube Bends After Bend

Sine Wave Tube Bend Checking Form

Thermocouple Wire Arrangement in Baffles

$8-1-3$

$8-1-4$

Lower Tube Sheet Thermal Shield Plate Assembly

$8-1-5$

Thermocouple Wire Arrangement Upper End

$8-1-6$

Start of Tubing Operation on Tube Bundle

$8-1-7$

$8-1-8$

Assembled Tube Bundle W1 thout Thermal Shleld

$8-1-9$

Inside V1ew Upper End of Tube Bundle

8-1-10

Lower Tube Before Tube Ends Are Cut to Iength

8-1-11

$8-1-12$

Tack Welds Between Tubes and Guide Rings

Sine Wave Tube Bend Assembly

Completed Tube Bundle with Thermal Shield

Iffting Tube Bundle for Entry Into Shell

$8-1-13$

$8-1-14$

8-1-15

Tube Bundle Entering Shell

Roller Expanding Tubes in Upper Tube Sheet

$8-1-16$

Unit in Plt for Tube to Tube Sheet Welding

View of Top of Scaffold for Thabe to Tube Sheet Welding

Close Up of Automat1c Tube to Tube Sheet Welding

Close Up of Tube to Tube Sheet Welds

Tube Attachment Welds on Lower Tube Sheet

8-1-17

8-1-18

8-1-19

$8-1-20$

$8-1-21$

$8-1-22$

$8-1-23$

Inside Upper Head

Strain Gages Inside Upper Head

Strain Gages Inside Upper Head After Waterproofing

$8-1-24$

$8-1-25$

$8-1-26$

Straln Gages at Steam Outlet on Jpper Head

Some Strain Cages at Sodium Inlet Before Mo1stureproofing

Some Strain Gages at Sodium Inlet After Moistureproofing

Venting Shel1 While F1lling for Pressure Test

Pressurizing Shell

Connecting Strain Gages to Recorder

Machining Water Inlet Nozzle After Tests

Protection of Thermocouples at Upper Head for Shipment

Protection of Thermocouples at Lower Tube Sheet

Wooden Shlpping Structure Over Untt on Truck

Protection of Thermocouples at Upper End

Tarpaulin Cover Protection

$8-1-27$

$8-1-28$

8-1-29

$8-1-30$

$8-1-31$

8-1-32

8-1-33

8-1-34

8-1-35

8-1-36

8-1-37

8-1-38 


\section{SECTION I}

\section{SUMMARY}

Page

INTRODUCTION

1-1-1

CONCLUSION

$1-2-1$

Page 1 


\section{INTRODUCTION}

Th1s report outlines the fabrication and inspection techniques used by Baldwin-Lima-Hamilton Corporation (BLH) to build the 30 megawatt prototype steam generator designed by Alco Products Inc. for the United States Atomic Energy Commission on Contract $\operatorname{AT}(11-1)-666$.

The purpose of this report is to enable a manufacturer of this design to make a fabrication and inspection procedure for the economic production of this steam generator and to call attention to areas of potential trouble.

Since each fabricator who may fabricate a unit similar to this will have routing slips, machine tools, welding machinery and radiographic techniques which w1II require different processing than used at BLH, emphasis will be placed on the unusual requirements of this design rather than minute detail of fabrication steps common to all nuclear vessels. Fabrication problems and solutions are detalled.

In some cases the problems relevant to the steam generator fabricated are discussed with methods used to correct the deficiency. In other cases, recommendations are made for modification of the design detall or fabrication requirement causing the problem.

Varlations from the speciflcations and procedures or drawings presented in the engineering reports APAE-112, Volume 1 , 2 and 3 and APAE-122 are given.

\section{HISTORY}

In early 1962 Alco Products, Inc decided to withdraw from the manufacture of heat trarsfer exuipment and sell the fabricating plant at Dunkirk, New York. The steam generator fabrication could not be completed before the scheduled closing date of the plant. The contract with Alco Products, Inc. was modifled and a contract arranged with Baldwin-Lima-Hamilton Corporation (BIH) to complete the fabrication of the steam generator.

Alco Products furnished BLH the sine wave tube bending machine and the special T.I.G. cold wire feed automatic welding gum. The special fixture for holding and positioning the gun over the tube hole was rented. Alco Products, Inc. had started fabrication on some parts which were shipped to BLH partially fabricated as noted in Section 1 . 


\section{CONCLUSION}

The steam generator fabricated under this contract can be fabricated by any manufacturer of nuclear heat transfer equipment. Special fixtures, tools and quality control instruments are required. Modification of some design detalis should be investigated to improve quality and economy. Further development of both the design and welding procedure for the tube to tube sheet attachment appears desirable.

This unit is inherently very costly to produce because of the b1-metallic tubing and Inconel overlay on the parts exposed to water. Alternate materials of construction should be invest1gated to avold a protective metallic layer agalnst the water or steam. 


\section{SECTION 2}

FABRICATION OF PARTS AND SUBASSEMBLIES

Page

Shell and Shell Nozzles

$2-1-1$

Impact Shroud and Thermal Shlelds

$2-2-1$

Baffles

Thermal Shield Plates

2-3-1

2-4-1

Guide Rings

2-5-1

Tube Sheets

2-6-1

Heads and Head Nozzles

2-7-1

Tubes

Lower Shroud Assembly

2-8-1

2-9-1 
Shell and Shell Nozzles

Pieces 2-1, 2-2, 2-3, 2-6, 2-7, 2-11, 2-14, 2-15, 2-17

The shell was recelved rolled and welded with certification of penetrant and radiographic examination completed.

Shell nozzle locations were marked on shell and holes were burned out by heliarc burning using 35\% hydrogen, 65\% argon cover gas. The weld kerfs were prepared by chipping and grinding. Nozzles were welded to shell in accordance with specifications and examined by penetrant and radiographic inspection.

Guide lugs were welled on and penetrant inspected.

Rounding and stiffening rings were added to each end of the shell as shown on photograph 8-1-2. Weld kerfs in each end of the shell were machined per drawing dimensions.

Comments: The 12 inch nozzles were recelved finish machined on inside and outside diameter to final dimensions. If accurate locations of nozzles are required, stock on both surfaces should be left until all shell welding is complete because of weld shrinkage and distortion of shell and nozzle. Finish machining of inside and outside surface can be done when shell and girth weld kerfs are machlned. Nozzle weld kerf machining should be left until hydrostatic test covers are removed.

The one inch and one and one-half inch I.P.S. nozzles were welded on with a full penetration butt weld, dye penetrant inspected and radiographed. For secondary sodium system service for small nozzles not subjected to major pipe loads BLH would recommend socket welds without radiographic examination because of difficulty in economically obtaining acceptable interpretable radiographs.

Guide lugs should be welded on with ample stock so that location can be machined to required accuracy. Final machining of the se lugs can be done when shell nozzles are machired or later, after complete assembly, when test covers are removed. BLH machined lugs when test covers were removed. 
Pieces 6-1, 6-2, $6-3,6-4,6-6-5,6-6,6-7,6-8$,

Plece 6-20, the nozzle liners, were recelved formed into cones. They were fitted to the shell nozzles (Plece 2-6), trimmed for the longitudinal welds and welded. All other pleces were received as flat sheet or unmachined plate.

Plece 6-9 was machined. Pleces 6-3 and 6-4 were rolled, welded and rerolled for final sizing and rounding. Pleces $6-3$ and 6-4 were hand ground to a taper as shown on drawings. Plece 6-3 was assembled to 6-9 and welded and then 6-4 was assembled to 6-9 and welded. This subassembly was positioned and welded to the shell. Plece 6-10 was assembled and welded to Piece 6-9.

Pleces 6-6 and 6-7 were rolled, welded and rerolled for final rounding. Plece 6-7 was hand ground to a taper at one end and assembled and welded to $6-9$ and $6-6$ in one operation. It was found that welding in this manner led to separation between the assembly of Pieces 6-6, 6-7 and the ring 6-9 due to shrinkage. A fillet weld was added between Pieces $6-6$ and $6-9$ on the top side. (See comments at end of this section.)

Plece 6-5 was rolled, welded and rerolled for rounding to size. Plece 6-20 was fitted to Piece 6-5 and cut to contour. Piece 6-20 was placed in nozzle Piece 2-6 and held in place while Piece 6-5 was inserted in Piece 2-2 to position. Piece 6-5 was marked for cut out at junction with 6-20. Piece 6-5 was removed from Plece $2-2$ and the nozzle hole cut. Piece $6-5$ was then reinserted in Piece 2-2 to position and Piece 6-20 fitted and welded to Plece 6-5. Clips 6-21 were then welded to Piece $2-2$.

Plece 6-2 was rolled as two halves to diameter. The leadIng edge which inserts between Pleces $6-3$ and $6-4$ was ground on $a$ taper to a rounded point by hand. The pieces were assembled on a dummy tube bundle. The six wedges (Plece 6-11) were welded in position and the complete shield smoothed on outside surface with hand grinders. Plece 6-20 was contoured to the outside of the shleld and inserted in nozzle $2-6$. The dummy bundle was inserted into Piece $2-3$ and slid in as far as possible. Difficulty was encountered as the end engaged Pieces 6-3 and 6-4.

The dummy bundle was removed and the opening between Pleces 6-3 and 6-4 enlarged by bending 6-4 toward the she 11 and 6-3 Inwardly, making short longitudinal TIG beads without filier metal. The bottom wedges were ground to $3 / 16$ inch thickness and three $3 / 16$ inch thick pads $1-1 / 4$ inch wide by 4 inches long were welded directly behind the three bottom wedges to give more bearing surface. 
The dummy bundle was again inserted and became very difficult to move about 7 inches short of its intended position with a 14 inch overlap with Piece 6-3. An analysis indicated that a 7 inch overlap would be acceptable so the shield was marked for Plece 6-20 hole and for the cut-off and withdraw. The shield cat-off was made and the pieces removed from the dummy bundle.

Piece 6-1 was rolled and welded and rerolled to size. Piece 6-8 was machined and drilled. Plece 6-1 was welded to Piece 6-8.

Position and alignment of impact shroud assembly 6-6, 6-7 were checked with a small dummy baffle nest. Minor grinding was required to permit passage of the bundle.

Comments: The major concern with the fit up of the thermal shield Piece 6-2 and the baffles into assembly 6-6, 6-7, derives from the galling properties of stainless steel when forced together without Iubrication. The fit up must be made with thin parts which are easily distorted and is made blind into an opening with very small clearance. Prior experience by another manufacturer with a similar assembly had required several trials with a completed bundle.

BLH did not wish to risk the possibility of damage to the tabe bundle which is flexible and hard to handle. Therefore a dummy bundle was made from scrap baffle material extending the length of Plece 6-2, as mentioned in paragraph 5 page 2-2-1. A separate small dummy tube bundle using baffle diameters of Plece 4-4 was made to check the impact shroud assembly. As a result of these prefit tests, required modifications were made without risk to the tube bundle. The insertion of the bundle into the shell proceeded very smoothly with no trouble.

The flilet weld used between Plece 6-6 and Plece 6-9 can be avolded if Plece 6-7 is welded to Plece 6-9 first. Then leaving a $1 / 4$ inch gap weld Plece 6-7 to Plece 6-9 and then fill between Pieces 6-6 and 6-7. 


\section{BAFFLES}

P1eces $4-1,4-2,4-3,4-4,4-5,4-6,4-7,4-8$
$4-9,4-24$

The long length of the baffled section combined with the moderately close baffle pitch and the outside diameter alignment required for the thermal shield tight fit makes it desirable to maintain close location tolerances on the tube holes.

The baffles were stacked and all fifty-four pleces drilled on a Iahr gun drill with tape control using the same tapes that were used for the tube sheets and thermal shield (Pleces 6-12 and 6-14). The baffles were arranged in the stack so that the stack could be broken apart in groups for additional drililing of tie rod holes which did not have the same location in all baffles.

Two base plates 31-5/8" diameter by one inch thick were prepared by Blanchard grinding both surfaces. A three inch diameter hole was burned out in the center of each plate and a one inch thick disc $7^{\prime \prime}$ in diameter was fillet welded over the hole. A one-half inch hole was drilled and reamed through the disc centered by the outside edge of the plate. As baffles were stacked two sheets of four mil polyethylene plastic were used as separators between each baffle.

First all the doughnut baffles (Plece 4-6) were stacked on the base plate, disc side up, and topped by baffle Plece 4-24. The stack was flattened on a press and six stainless steel bars 5-1/4 inch long by $1 / 4$ inch square were welded on equally spaced around the periphery with fillet welds the full length.

Similarly the second stack was assembled using baffle 4-7 as a base. Then 4-1 and all 4-8 baffles were topped with baffle 4-9. Again six bars 6-1/4 inch long were fillet welded to the press flattened stack. Both of these stacks were made of baffles $31-5 / 8$ inch outside diameter with the solid baffles having a $1 / 2$ inch hole in the center.

A third stack of 24-1/4 diameter baffles was made up with baffle $4-3$ on the bottom followed by $4-2$ and $4-4$ baffles. Six bars $2-1 / 2$ inch long were welded to this stack.

All stacks were assembled together and baffles $4-5$ and 4-10 added to the top of the third stack. The second base plate was then added with the disc fitting down into baffles 4-5 and 4-10. A $1 / 2$ inch diameter rod threaded at each end was pushed through the $1 / 2$ inch holes in base plates and baffles. Nuts were applied at each end and tightened. The countersunk construction of the discs on the base plate kept the top of the nuts below the surface of the plates. 
Six stainless steel bars 17 inches long by $3 / 8$ inch square were fillet welded to both base plates and to all the large diameter baffles.

The long bars and center rod held the stack securely during driliing. Cutting the long bars separated the baffles into stacks for reaming and tie rod drilling. Baffles 4-1, 4-4-, 4-7, 4-8, 4-9, 4-24 all have special tie rod drilling. Some driling can be done on the stack but these baffles must be split off to complete all the drilling.

Some baffles serving a support function (Pleces 4-5, 4-10) required different size holes. Therefore, the driling of the large stack was done with the same size drilis used on the tube sheet and then the separated stacks were reamed to final size.

Baffles were then machined to final OD for discs and OD and ID for doughnuts using the tube holes for locating the true center of the baffles. Baffles were stamped on edge with plece number, sequence number and an orientation mark to insure proper alignment in assembly.

Each baffle was separated and deburred. Then each tube hole was given a slight chamfer with a high speed portable air tool on both sides of each baffle. After chamfering, each hole was inspected carefully and abrasives were used to clean up any remaining burrs.

Comments: Where a tape controlled Iahr gun drill is not available, it would be practicable to use a carefully made drill $\mathrm{jIg}$ and use this $\mathrm{JIg}$ to spot the shell side of the tube sheets and guide radial drilis into short baffle stacks. In this case tube sheet and baffle stacks should be marked to preserve orientation.

It is imperative to be careful in chamfering and deburring the tube holes to prevent scoring or gouging of the tube surface during assembly or wear during operation. 


\section{THERMAL SHIEID PLATES}

$$
\text { Pieces 6-12, 6-14 }
$$

The thermal shields were drilled on the tape controlled Iahr gun drill and reamed to size. Tube holes were chamfered on both sides of each plate and all the holes carefully deburred.

Comments: The thermal shield plates are mounted on a very close $\frac{\text { spacing }}{1 / 8 "}$ gap) and start very near the tube sheet $\left(1-1 / 8^{\prime \prime}\right)$. Consequently, any mislocation in driling either baffles or tube sheet cannot be absorbed in the flexibility of the tubing. Therefore, although the tube holes are 1/8" larger than the tube diameter, it is important to maintain proper hole location.

The thermal shields could be drilled on a radial drill using the same drill $\mathrm{jlg}$ that was used to spot the holes on the tube sheets and gulde the radial drilis in driling the baffle stacks. 


\section{GUIDE RINGS}

$$
\text { Pieces 4-13 (A, B, C, D, E) }
$$

The guide rings are used to hold the sine wave tube ends in position while the upper tube sheet (Plece 2-4) slides over all the tubes into position. Since the assembly must be made without lubricants to avold welding difficulties and contamination problems, the tubes must rub the tube holes with minimum pressure to avoid galling of the stainless tube in the stainless tube sheet. Therefore, the tube holes in the guide ring must be accurate both in location and angle.

The guide rings were completely machined on OD and ID and for the interlocking fit between rings. Then tube holes on each ring were laid out, drilled and reamed to dimension. Tube hole location and angularity were inspected by means of 4 inch pins with vernier measurements between holes and across chords of groups of holes. By this measurement an appreciable number of holes were out of location.

It was decided to try drilling by tape controlled gun drill and new materlal was purchased, machined and drilled. By this time the upper tube sheet had been drilled and it was decided to check the rings directly against the tube sheet with short pieces of tubing.

It was found that the number of acceptable holes varied in each ring, depending on the ring orlentation to the tube sheet. Since the tube layout is on a circumferential pitch, the rings were tried in all positions and the position with the greatest number of acceptable holes noted. The original rings drilled on the radial drills matched better of the two sets. Ten holes had to be relocated.

The correction for each hole was determined by filing the end of a piece of tubing on one side until it fitted through the guide ring in full diameter and the filed portion fitted into the tube sheet. The offset was measured and the direction marked on the hole in the guide ring. See repair procedure, page 5-1-1.

Tube holes were chamfered and deburred on both sides in the same manner as the baffles.

Comments: The guide rings are required both to hold the position and orientation of the sine-wave tube bends and support the tube ends as the upper tube sheet is pulled into position. Therefore, hole location should be accurate. 
It might be possible to avoid errors in hole location by mounting the machined and assembled rings on the shell side face of the upper tube sheet before drilling. Then, either the gun drill or a drill $\mathrm{jig}$ would be used to drill the guide rings and spot the holes of the tube sheet. The guide rings would be removed before continuing with the tube sheet drilling.

The fact that the tape controlled gun drill did not give more accurate location of holes on the guide rings may be due to the method of mounting and clamping the work in position. A radial drill usually clamps the work down on the bed with minimum side pressure. The gun drill being horizontal requires vertical mounting of the work which may place more force on the sides of the rings and cause some distortion.

Although tack welding is recommended to fasten tubes to guide rings (see Comments on Page 3-1-5), some developmental work might show feasibility of roller expanding with smaller diameter tube holes and moving the guide rings further from the sine wave bend.

BLH does not believe that the interlocking of the rings is necessary and recommends that the rings be machined flat on all $O D^{\prime} s$ and ID's. The rings are tack welded together during assembly which will prevent movement between rings. The interlock shown does not prevent movement during assembly of tubes into tube sheet since the inner row becomes loaded first as the longer inner tubes enter the tube sheet. 
TUBE SHEETS

Pleces 2-4, 2-5

The tube sheets were recelved with the Inconel overlay applied, rough machined and ultrasorically tested. The tube sheets of 316 stainless steel, 6-5/8 inches thick with $7 / 16$ inches of Inconel overlay, are very difficult to drill maintaining hole diameter and drill run off within tolerance.

It was decided to use tape controlled Lahr dri11s with two drilling speeds. Because of baffle line up and driling conditions, the tube sheet driling was started from the shell side and the stainless was drilled to within 1 inch of the other face. Then, because of the hardness in the fusion zone between Inconel and stainless, the drill speed was cut back and the hole finished at the lower speed.

When working with stainless steel, the drills must be kept sharp or a chip may grab and enlarge the hole. Sometimes this may make a barrel shaped hole and sometimes a trumpet shaped hole.

Examination of the lower tube sheet revealed that many holes were out of tolerance. However, only two of the holes were larger in local areas than those specified for the upper tube sheet. It was decided to use the tube sheet without repair.

The upper tube sheet had two holes that could not be accepted. The repair procedure is glven on page 5-2-1. Measurements through the lengths of both holes are given with the repair procedure.

The tie rod holes, vent, drain and thermocouple holes were drilled on a horizontal mill. On the upper tube sheet, holes $\mathrm{M}-1, \mathrm{M}-2, \mathrm{M}-3$ and $\mathrm{M}-4$ are in bullt up weld metal pads. These were machined to the proper vertical location on a vertical boring mill before the holes were laid out and drilled.

The shell side of the tube holes was chamfered on a drill press. The tube holes on the tube side with the Inconel overlay were trepanned to form welding lips in accordance with the drawings.

The weld kerfs on the shell side were machined to match the measured dimensions of the mating end of the shell. The weld kerf was centered on the tube layout rather than on the existing lip dimensions. 
The weld kerfs on the tube side were machined to drawing dimensions with partioular care to make sure that the Inconel overlay was completely machined off in the stainless weld area.

Comments: Special precautions must be taken to protect the trepanned tube hole lips and the tube sheet weld kerfs from damage. Damaged lips may lead to costly repaizs of welds.

If the fabricator has not had experlence in drilling an Inconel overlaid stainless steel forging, it is recommended that a mock-up be made and drilling problems studied.

Inconel overlay must be removed completely in stalnless steel welding area because stainless welded over Inconel cracks, and a satisfactory weld cannot be obtalned. BLH recommends both visual and acid tests to prove complete removal of overlay (see Page 4-1-1). 


\section{CHANNEL HEAD AND HEAD NOZZLES}

Piece 3-1 and 9-1

The heads were recelved with the nozzle welded in, all dye penetrant and radiographic inspection completed, interior surfaces of nozzle and head overlaid with Inconel, machined and ultrasonic tested. Contrary to specifications, the heat number, working pressure, working temperature drawing number, name of part, National Board number, serlal number, year, ASME Code symbol, subvendor's mill number, type of materlal and ultimate strength were all stamped in large letters on the forgings. This is common commercial practice and may happen despite all reasonable precautions. Since special parts of this nature usually have a long delivery and cannot be readily replaced, the fabricator is faced with either accepting the part and repairing 1 t or having a delayed schedule.

The stampings were carefully examined and were found to

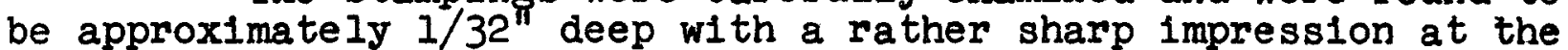
bottom. A review of possible repair procedures, all of which included the addition of weld metal, led to the conclusion that more damage might be done to the base metal than had been done by the stamping. Therefore, the stamping was left on the pleces.

There were other areas in which the head conflguration did not conform to the drawings. One of these was the lack of a radius at the inside juction of the steam nozzles and the head. The drawings called for a $1-1 / 2$ inch radius. Since $1 t$ was not possible to determine if the stainless had been properly rounded prior to the application of the Inconel overlay, it was decided to grind approximately a $1 / 8$ inch radius and then penetrant inspect this area. After penetrant inspection the Inconel was tested with the Inconel clad test procedures (see Page 4-1-1).

The penetrant inspection of the grinding on the upper head revealed a crack in the overlay. This was ground out almost $1 / 2$ inch deep before the penetrant showed sound metal. The Inconel clad test procedure was applied and the stainless steel reaction showed that the crack started with the root pass.

The manway cover stud holes were drilled and tapped. The thermocouple holes in the upper head steam outlet nozzle were drilled.

The weld kerfs to attach the heads to the tube sheets were machined to match the tube sheets with special attention to the removal of the Inconel overlay. The weld preparation was tested with the Inconel clad test procedure to make slire all Incorel had been removed. 
Comments: The spherical head with manway and nozzle is awkward to overlay with Inconel and machine to contour. Special tools capable of following a contour pattern are required for automatic overlay and machining. In addition, hand grinding of many areas is required. 
TUBES

Rows $1,2,3,4,5$

The bimetallic tubes were recelved ultrasonically inspected. The outside of the tube was .072 inch thick minimum, type 316 stainless steel with an internal iner of .032 inch thick minimum Inconel metallurgically bonded to the stainless. The tube $0 . D$. measured .523 inches and the $I . D$. measured . 308 inches. The tubes were purchased in five lengths - one length for each row so that a pyramid of tube ends would be formed on assembly with the longest ends on the inner row. See P1cture 8-1-10.

The tubes were formed Into the sine wave bend by means of a special machine furnished by Alco Products, Inc. A different rotating die was required for each row of tubes. Each tube was Inspected against wooden forms to prove the three dimensional accuracy of the bend. See Pictures $8-1-3,8-1-4$ and $8-1-5$.

Each tube was pressure tested with dry nitrogen gas at $620 \mathrm{psig}$ after bending. The tubes were then carefully cleaned with acetore on the outside. The inside was cleaned with acetone swabs blown through by bottled dry nitrogen. Tubes were capped unt1l assembly.

Comments: The metallurgicaliy bonded tubing is expensive and only superior Tube Company has had experience in fabricating. It was difficult to get meaningful ultrasonic readings on the tubing.

In locating the tube bends, all measurements should be made from the long end of the tubing. Since both ends of the tubes move into the die, settings must be determined experimentally for each row. An allowance of at least one inch extra length should be left at the lower tube sheet.

The pressure test with dry nitrogen was recommended because of the lack of experience in forming this bimetali1c tubing. Many years before some early bimetalilc tubing split longltudinally on bending. The tests performed here and examination of the tubing indicates a low probability of damage from the bending. Therefore, these pressure tests might be considered redundant. 


\section{IOWER SHROUD ASSEMBLY}

Pleces 4-1, 4-2, 4-4, 4-7, 4-12, 4-17, 4-18, 4-21

Shroud Plece 4-12 was rolled, welded, penetrant inspected and rerolled to roundness required. Pieces 4-1, 4-2, 4-4 and 4-7 were prepared as outlined under Baffles, page 2-3-1. Plece 4-I was la1d out for tabs and cut to shape by a band saw. Plece 4-12 was lald out and notched by hand grinding with an abrasive wheel. Plece 4-7 was assembled and fillet welded to Plece 4-12, taking care to center 4-12 with respect to 4-7 and to match orientation marks.

Pleces 4-2, 4-4, 4-1, 4-17, 4-18 and 4-21 were assembled and aligned. Tie rod nuts were tightened to hold structure in place, but final tightening and welding of nuts was not done unt1l assembly was added to tube bundle and all baffle alignments checked.

Comments: It is probably not necessary to notch the shroud Plece 4-12 as shown on the drawings. Shroud could be cut 3/16 inch shorter and Plece 4-1 positioned and tack or fillet welded to 1t. In view of the six internal tie rods it is probably not necessary to have the tabs on P1ece 4-1 elther. The operations to fabricate as drawn are not a significant part of the total cost but are costly in relation to possible advantages. 


\section{SECTION 3}

\section{ASSEMBLY}

\section{Page}

Tube Bundle

Tube Bundle into Shell

Upper Tube Sheet Assembly

Tube Sheet to Shell Attachment

Tube to Tube Sheet Attachment

Head to Tube Sheet Attachment

Thermocouples

Strain Gages

Preparation for Shipment

3-1-1

$3-2-1$

3-3-1

3-4-1

3-5-1

3-6-1

3-7-1

3-8-1

3-9-1

Page 3 


\section{TUSBE BUNDLE}

Every part used in the assembly was thoroughly cleaned with acetone before assembly. The assembly was kept covered with plastic when operations permitted. Only bottled dry nitrogen was used to blow out parts--never any shop air. White gloves were used for final assembly of tubes into tube bundle to avold fingerprint marks.

The lower tube sheet was placed on edge and the three thermocouple nozzles, Pieces 2-16, were welded on, penetrant and radiographically inspected. With the tube sheet in a horizontal position the thermocouples were assembled through the nozzles and the thermocouple buttons welded to the shell side of the tube sheet. The wires were restrained to configuration by means of handmade staples fashioned from 1/16" diameter bare weld wire. The staples were welded to the tube sheet. (See Picture 8-1-24 for a similar installation on the upper tube sheet.) The thermocouple plugs were welded to Pieces 2-16 with the tube sheet standing on edge and the welds were penetrant inspected.

W1th the tube sheet again in a horizontal position assembly 6-1, 6-8 was bolted to the tube sheet and the bolt heads tack welded to Piece 6-8. Then studs Pleces 6-16 were driven in and the thermal shield plates assembled (Pieces 6-18, 6-14, 6-22, 6-12, 6-17). The nuts were not tightened until the alignment of every tube hole was checked w1th short lengths of tubing. When final alignment was achieved, the nuts were tightened and welded to the studs and washers and the washers welded to the outermost thermal shield.

W1th the tube sheet on edge the baffle nest was assembled horizontally to the tube sheet, paying careful attention to the sequence numbers and orientation marks. The subassembly of the lower shroud (Page 2-9-1, Pleces 4-1, 4-12, 4-7 1nclusive) was held in place and tie rods 4-14, 4-15 and spacers 4-19 were placed in position and the tie rods were screwed into the tube sheet.

Baffles 4-6 and 4-8 were then assembled on tie rods with spacers 4-21. After baffles 4-24 and 4-9 were placed in position the tie rods 4-15 had nuts and washers assembled on.

Baffles 4-4, 4-2, 4-5 and tie rods 4-16 and spacers 4-21 and 4-20 were assembled onto the bundle w1th the nuts and washers. Nuts and washers were added to tie rods 4-14. Then the tie rods 4-25 and spacers 4-26 were added and baffle 4-10 placed in position and held with nuts and washers. 
Some tubes were inserted full length to assist in aligning the baffle holes with the tube sheets. (See Plcture 8-1-9) Before final tightening and welding nuts on tie rods all tube holes were checked for alignment with the tube sheet.

Thermocouples were then strung through the bundle and three of them welded to the face of the outer thermal shield plate as shown in Pictures 8-1-6 and 8-1-7. As each thermocouple ended in a space between disc type baffles, it was wrapped helically around the bundle of wires leaving only 2 or 3 inches free. This might reduce fallures from fatlgue caused by flutter induced by the sodium flow.

Half rings were prepared and fitted around the thermocouple wire bundles. To hold the wires tightly at center of disc baffle, the half rings were welded to the disc baffles. Refer to Picture 8-1-6.

The thermocouple wines were separated at baffle 4-3 into their individual bundles. They had been furnished as 6 bundles. The small bundles were stapled to baffles 4-5 and 4-10 wth staples of bare 316 welding wire. Refer to P1oture 8-1-8.

In the trial fitting of the dummy baffle nest inside the impact shroud (Piece 6-6 and 6-7) as described in Section 2-2, it was realized that some means of lifting the baffle assembly up into 6-7 would be required. No provision had been made in the design for such a device.

Six pieces of 5/8 inch square bar 78 inches long were obtained (Piece 4-27 on Drawing F-42207-1-4) and welded to the inside of Pieces $4-5$ and 4-10. Refer to P1cture 8-1-8 showing bars welded to Piece 4-5. Later they would be welded to guide ring Piece 4-13A. The six bars form a structure which can be raised by a beam to bring guide rings and baffles into line with Plece 6-7. See Picture 8-1-16.

The inner row of tubes was inserted into the baffle nest and brought through the lower tube sheet. Guide ring Plece 4-13A was placed over the tube ends and tubes sprung into it as tubing assembly progressed. P1cture 8-1-9 shows the first row of tubes being assembled with gulde ring A holding tube ends in position. After all tubes were in position the guide ring was moved to its permanent position near the sine wave bends.

Each tube must be oriented longitudinally so that all bends start in the same transverse plane. Then each tube must be rotated so that the sine wave bend follows the cylindrical plane along which the bend must 11e. When each tube was positioned, 1t was roller expanded into the lower tube sheet to hold the position. 
To position the tubes and hold them for the expanding operation various schemes of combs and wedges were tried with moderate success. The most successful scheme was the use of a wooden ring with the proper I.D. matching the O.D. of the tubing ring being positioned. Placing this ring around the middle of the sine waves as shown in Pictures $8-1-10$ and $8-1-11$ enabled the men to bring the bends into the proper position and hold them there during expanding with ease and rapidity.

After the first row was fastened in position, the second row was similarly added and guide ring $B$ moved into position over guide ring $A$. The rings were then tack welded together.

The fabrication procedure furnished with the drawings called for the tubes to be expanced into the guide ring as well as the lower tube sheet when they were positioned. It was felt that there was a possibility that the edges of the guide rings might deform when the tubes were expanded. Therefore, the first row of tubes was not expanded into the guide ring until the second guide ring was in place.

Preliminary tests were made of the expanding tools with an electronically controlled maximum current demand controlling the maximum torque of the expander motor. These tests and the expanding of the tubes into the lower tube sheet proceeded satisfactorily. Some of the first row of tubes were expanded into guide ring $A$ with no evidence of serious trouble. Then an expander cage and mandrel broke off and became lodged in the tube. It was necessary to dissolve these carbon steel parts with nitric acid which did not attack the Inconel liner. In all, three sets of expanders broke in the course of trying to roller expand the first row of tubes into guide ring A. All roller expander tool parts were removed by acid.

A boroscoplc examination revealed roughening of the Inconel surface in all tubes. Because it appeared impractical to continue expanding, a tack weld between the outside of the tube and the guide ring was tried on a test sample. This seemed satisfactory and welders were qualified on additional samples. All tubes in the first row and all subsequent tubes were tack welded to the guide rings as shown in Picture 8-1-13.

During all operations tubes were kept plugged with plastic caps whenever possible. P1cture 8-1-12 shows the lower tube sheet with the trepan lip for each tube attachment weld and plastic caps in expanded tubes. P1cture 8-1-11 shows the caps in the other end.

After all tubes were tack welded in position the inside surface of all tubes at the guide ring location were examined by boroscope. Three areas showed a fuse through at the tack weld. 
Pictures of these surfaces and the results of the examination are given on Page 4-4-1. Later these three tubes were plugged with plugs machined from inconel bar.

To prepare the tube bundle for assembly into the shell a surplus guide ring with a large chamfer on the outside leading edge (see Section 2-5-1) was placed over the outer row of tubes.

Tubes, baffles and thermal shield were given a final cleaning and then the thermal shield pleces 6-2 were assembled over the bundle and the edges welded in accordance with the drawing.

The six square bars (Plece 4-27) were welded to guide ring A. Short pleces of the same bar (Plece 4-28) were welded near the bars on guide ring A to protect the thermocouple leads which were stapled between them. See P1cture 8-1-11.

Pleces of 1 inch by 4 inch wood were taped to guide ring $A$ and the thermocouple leads were taped to the bars to support the leads Inside the shell. Refer to PIcture 8-1-15.

A 6 inch by 8 inch wooden beam was covered with tape to maintain cleanliness and Inserted into the baffle nest (see Plcture $8-1-16$ ).

Comments: It is Important to carefully deburr and clean al1 parts as assembly progresses since many areas become inaccessible later. As each tube is assembled 1 to bundle, each tube hole in lower tube sheet and each tube end is given a final wipe with acetone as tube is inserted into tube sheet.

Extreme care must be taken in handing the thermocouple wires as they are quite fragile and repair is difflcult even when fully accessible.

Baffle assembly should not be finally tightened and nuts welded until allgnment of all holes has been checked through the lower tube sheet with a trial tube.

The original fabrication procedure required that the tubes be expanded into both tube sheets and the guide rings which would be a normal procedure for most tubing. Other heat transfer equipment of similar design with elther different size tubing or lighter tube walls has been successfuliy and easily fabricated by roller expanding of the tubes.

In this particular design, with the bimetalilc tubes of inconel lined stainless and the thick tube wall with a small diameter tube, unusual difficulty was encountered unexpectedly in the expanding operations. 
The following factors contributed to the erratic results obtained in the various expanding operation:

A. A work hardening material on the outside (316 stainless steel) and a softer liner (Inconel) with a possibly harder fusion zone between the two metals.

B. Tube straightening operations after the final anneal may have slightly work hardened the material in local regions.

C. Material at the edge of the sine wave bends was slightly bent and then straightened to conform to contour adding some work hardening adjacent to the start of the bend in the guide ring region. An electronicaliy controlled expander was used to limit the torque applied. The variations in settings required to expand indicated the varied work hardening of the material.

D. The Inside diameter of the tubing is so small that the expander parts are very delicate and are highly stressed in moving the heavy walls of the tubing.

E. The movement of the wall is larger in relation to diameter than normal. The gulde ring and upper tube sheet holes were .537 to .540 I.D. Tube $0 . D$. was .523 making a movement of .014 to .017 Inches on a one-half inch tube. Common practice would normally limit this to .005 to .007 inches on this size of tubing.

F. The required $O . D$. to achleve a fit to the tube sheet is at the limit of the expanding tools. If tube does not fit on first expansion, additional attempts to tighten tend to break the expander.

If the fabricator feels that the risk of a fuse-through at the guide ring tack welds is too great, experimental work should be undertaken to improve probablitty of success with roller expanding. Suggested changes in design for such improvement are:

1. Move guide ring location 2 or 3 lnches further away from sine wave bend. This may require lengthening the shell.

2. Reduce the diameter of the holes in the guide ring to give only .006 inch clearance over the outside diameter of the tube. (In the case of this unit the hole would be .529 to .531 inches.)

3. The risk of damage to the inside surface from roller expanding (see Pages 4-4-1 through 5) must be reduced befcre committing the unit to these risks. Therefore, 100 samples using bent tubing similar to that for production should be tried and examined to qualify the procedure.

4. In spite of this qualification care must be taken to reduce danger of damage from the breaking of the delicate and fragile expanding tool. 
BLH recommends tack welding the tubes to the guide ring in accordance with the following procedure.

Qualification samples should be made and examined for the tack welding procedure. Each welder should be able to produce ten tack welds with a minimum penetration one quarter and a maximum penetration three quarters through the stainless portion of the tube. If possible, boroscopic inspection should be made in guide ring area on the inside of the tubes to ascertain that fuse through has not occurred and cracks have not been generated by welding.

A. Make temporary rings split in half with the inside diameters equal to the outside diameters of each row. BLH used wooden rings as shown in P1ctures 8-1-10 and 8-1-11.

B. Assemble tubes into baffle nest one row at a time springing tube ends into guide ring held at end of tubes until row is all assembled. Slide gulde ring into final position.

C. Put temporary ring from step $A$ at mid point of sine wave bend and hold each tube against inside of ring with tape or plastic wrapped wire unt1l all tubes are in proper position.

D. Tack weld each tube to guide ring. Pin each tube into lower tube sheet by rollen expanding the tube end only. Expanding should be done so that tube is enlarged approximately $1 / 4$ inch above tube sheet and is snug to trepan 11p. Tube should be expanded about $1 / 2$ to $3 / 4$ of an inch below surface of tube sheet. tack welded.

E. Tack weld gulde ring to adjacent ring as tubing is

F. Fabricate a dummy guide ring for outside row of tubes with a large chamfer on outside leading edge to ease entry of bundle into thermal shroud Plece $6-7$ and place over tube ends on outside row.

Expanding done in Step $D$ helps to hold the long straight tube in position and therefore one end of the sine wave bend is held by this and the other end by the tack weld to the guide ring. This pinning-expanding is also required to align the tube at the tube to tube sheet weld and reduce the bending in that weld by reducing clearance. 


\section{ASSEMBLY OF TUBE BUNDIE INTO SHELL}

The tube bundle prepared with wooden pleces holding the thermocouples and the taped wooden beam in place was lifted as shown in P1cture 8-1-16. Protective wooden pieces were placed to span the several baffles extending beyond the thermal shleld. The tube sheet was fastened separately to the holsting beam and four additional rope slings were used around the bundle to keep this very flexible bundle stralght.

The holsting beam above the bundle was held by two independently operated hooks. The main welght was carrled on the crane nearest the tube sheet. The second hock was needed to steady the bundle as it entered the shell.

In front of the shell end a bed of rollers was placed and pleces of wood were used as shims to help support and center the shleld as it entered the shell. See P1cture 8-1-17.

The thermal shield for the sodium outlet nozzle, Plece 6-20, was inserted and held in position by two support bars tacked to the inside of the shroud and to the nozzle.

As the bundle entered the shell the slings were removed progressively until the lower tube sheet rested on supporting structure and the crane and hoisting rig could be completely disconnected. A come-along was attached on each side of the lower tube sheet and to the guide-lifting lugs on the shell to pull the bundle into position.

When the tube bundle had entered the shell far enough that the inner most ring of tubes were entering the thernal shroud (Piece 6-7) a small hydraulic jack was placed on a roller traveler and under the $6 \times 8$ wooden beam to lift the assembly into the shroud. The tube bundle overhanging the thermal shield is sufficiently flexible that the end of the tubes were approximate'ly 6 inches lower than their proper position before being lifted into the shroud.

As the roller traveler, jack and bundle moved into the shroud the area vacated by the traveler was wiped clean with acetone. The fack and traveler were removed af ter both the leading extra guide ring and the regular guide ring set were in the thermal shroud.

When the set of guide rings came out of the top of the thermal shroud, they were plcked up by the hydraulic jack and roller traveler and raised slightly to reduce the rubbing of the sine wave tubes on the thermal shroud. The shroud is shorter than the distance between the guide rings (P1eces 4-13) and the last baffle (Plece 4-10) permitting the tubes to ride on the shroud. By placing taped 
wooden blocks on the wooden beam at baffle 4-10 and using the guide rings as a fulcrum 1t was possible to raise baffle 4-10 by depressing the exposed end of the beam. The tubes were held away from the thermal shroud and baffle 4-10 brought on to the end of thermal shroud Piece 6-7 very smoothly with no damage to the tubes. The area vacated by the traveler was cleaned as the bundle moved into position.

When the bundle was several inches short of the final position, the lower tube sheet weld kerf and the matching shell weld kerf were given a final cleaning. Then a cleaned EB insert was fitted and tacked to the shell. The thermocouple wire bundles were removed from the wooden supports and threaded across the tube rows. The thermocouple plugs were inserted into the holes in the shell and tack welded in place.

Then the bundle was moved to position very carefully whlle fitting the lower tube sheet weld kerf to the EB insert by adjusting the helght of the tube sheet with a traveler and jack combination. The tube sheet weld kerf was then tacked to the EB insert. Four support bars were welded to tube sheet and shell to support the tube sheet.

Comments: It is important to make sure of the following items before starting assembly.

1. Make sure thermal shield, guide rings and baffles 4-5 and 4-10 will fit into mating thermal shield and thermal shroud.

2. Make sure machined weld kerf on shell dimensionally matches weld kerf on lower tube sheet.

3. That shell and bundle are clean.

4. That adequate support is proviled for tube bundle to prevent damage to bundle whlle lifting bundle into position.

5. That a means is provided to lift gulde rings and first baffle into thermal shroud.

The thermocouple plugs should be inserted in the shell holes before the guide rings pass the hole in order to minimize the amount of bending the thermocouple sheaths recelve during installation. 


\section{UPPER TUBE SHEET ASSEMBLY}

The taped wooden beam and the blocks were removed from the tube bundle assembly. The dummy outer gulde ring was removed and the wooden supports for the thermocouple bundles. The thermocouple bundles were moved out of the way and the tack welds between the guide rings and the six square bars (Plece 4-27) were ground out with an abrasive wheel. This freed the baffle structure from possible restraint through the guide rings, tubes, tube sheet to she 11.

The thermocouple wire bundles were positioned and tapled to the guide rings with $1 / 16$ inch diameter stainless steel bare weld wire. The thermocouple bar plugs were welded into the shell with a fliet weld which was penetrant inspected.

The three Inch wide strip of stainless steel was formed Into a cylinder (Plece 4-29) and was welded to the six bars (4-27) so that they could not get below and catch on the edge of the guide rings during a thermal transient.

The ends of tubes were tapered with a small hand grinder and cleaned. Bull nosed plastic pliots were inserted in tube ends. The special ring fixture with holes for guide pins was fastened to the shel1 (see Plcture 8-1-18) and the guide pins inserted.

The upper tube sheet was thoroughly cleaned and the special ring fixture fastened in place. Thermocouples were then installed and welded on the shell side with the wires stapled over to the access holes prepared. The thermocouple bar plugs were welded in and the welds were penetrant inspected. After a final cleaning the tube sheet was mounted on the guide pins through its special ring fixture. The welght of the tube sheet was supported by a hydraulic jack mounted on a roller traveler to reduce the load on the guide pins, tubes and plastic plugs.

The special ring fixture had provisions for both the guide pins and long threaded studs. The nuts on the studs were turned down in rotation to keep the tube sheet perpendicular to the tubes at all times and reduce the chance of a tube binding and galling. The inner ring of tubes were fed into the tube holes first and each row successively until all were entered. The tube sheet was pulled on until it was three to four inches away from the shell.

The weld kerf's were cleaned with acetone and an EB ring inserted and tacked to the she11. Then the tube sheet was pulled into position and tacked to the EB insert. Four support bars were welded to tube sheet and shell to support tube sheet. 
Comments: Theoretically it should not have been necessary to grind the ends of the tubes to a taper when pilots are used. Plastic pilots with spring centering devices had been recommended and might have been satisfactcry for thinner wall tubing. BLH would strongly recommend solid metal pilots with a slight amount of taper on the tube outside so that the leading edge of the tube was at least .010 inches inside the tralling edge of the pilot. With a thick walled tube like these it might well be practical to taper the tube end enough to eliminate the need for a pliot entirely.

Ring fixtures on shell and tube sheet with rigid guide pins and long threaded studs are necessary to maintain alignment and prevent rotation and cocking. On the fixture used, the fit between the guide pins and the sliding ring on the tube sheet was tight so that any appreciable cocking would cause the tube sheet to hang up on the pins before such cocking could cause a tube to gall in its hole. It is probable that this provision may be overly cautious and reasonable care in tightening the nuts in proper sequence is adequate.

As noted in Section 2-8 the tubes were purchased in five lengths to form a pyramid in assembly as shown in Picture 8-1-15. It would make the assembly of the upper tube sheet even easier if the difference between tube lengths were 1ncreased to 4 inches. Then after assembly of each row into its guide ring the tube lengths could be cut to a slight taper from top to bottom. This would allow the tubes at the top to enter the upper tube sheet first and tube entry occurring progressively down both sides until the bottom tube enters. When all tubes in a ring approach entry at once or at random locations it is more difficult to align them into the tube holes. 
After the upper tube sheet had been pulled into position and support bars welded to the shell, the guide pins, pulling studs and tube sheet guide ring were removed.

The gap between weld kerfs on the lower tube sheet was covered over with gummed paper masking tape and a hose was inserted under the tape. Argon gas was allowed to flow in under the tape while a vacuum was pulled on the shell to approximately 25 inches of mercury. The vacuum was broken with Argon. The unit was pumped down and purged w1th Argon three times. This elaborate procedure was felt to be necessary because of the difficulty in assuring the complete purging of the space between the thermal shield and the shell.

After the purge was completed a flow of Argon was continued into the shell through a sodium nozzle. A cardboard flap over a hole in another sodium nozzle kept a slight positive pressure inside the shell until the root pass and two additional layers on each tube sheet were completed.

Since the shell had been purged for the lower tube sheet weld, the vacuum was pumped down only twice for the upper tube sheet while the weld area was enclosed with tape and purged with Argon.

Following the welding procedure given in Section 6-2-1, the root pass was penetrant inspected and followed w1 th two additional layers of weld using Tungsten inert gas with $1 / 16$ inch dlameter wire filler rod. During these two weld layers the Argon back up was maintained.

Af ter the TIG weld layers two additional layers were welded using manual stick welding. Upon completion of the manual welding the weld was radlographed (see Section 4-2-1). There were no weld repairs required.

After these welds had shown clear, layers of weld were added by the submerged arc process. The weids were ground and radiographed after they were halfway up and at completion. There were minor repalrs required both halfway up and at completion. All repairs were quite shallow.

Both tube sheets were welded up by this method with the welding being performed alternately at each end. After the lower tube sheet to shell weld was completed (Plece 6-20) the sodium outlet nozzle thermal shield was welded to the nozzle and to the thermal shield (Plece 6-2). The support bars had been ground free before welding, taking care to protect the bundle from particulate matter by masking off the opening below the supports.

$$
3-4-1
$$


Comments: BLH belleves that the vacuum purge of the shell and maintaining the purge gas until the weld was thick enough to be assured that there was ilttle chance of a fuse through was worthwhile. Another manufacturer had not taken these precautions and had difficulty in meeting the quality control requirements. The vacuum purge seems to be the only way to replace a1n with Argon behind the thermal shield at the lower tube sheet.

Radlography taken in steps as the weld bullt up gave assurance that defects would not be deeply burled and could be readily found and repaired.

The original specifications for this weld called for a manual weld to completion in accordance with Style 3 on Page 6-1-6. BLH welding engineers felt that a better and less expensive weld could be made using submerged arc welding as shown on style 3A Page 6-1-16. The decision to change and approval came too close to the weld date to have wire specially made to meet the low ( I to $3 \%$ ) delta ferrite content specified. A lot of wire was avallable having an analysis which would give a 3 to $5 \%$ delta ferrite content as read from the Schaeffler diagram. This was purchased and used. Subsequent analysis of the deposited weld metal showed a probable $7 \%$ delta ferrite content.

Discussions with reputable metallurgists seemed to give little agreement as to the consequences of a higher ferrite content. A low ferrite content may lead to cracking of the weld during or after fabrication. High ferrite reduces cracking but may lead to formation of sigma phase in the weld which will be more brittle when cold.

The steam generator will seldom be cold and when cold will have little stress on the welds. Therefore the higher ferrite was thought acceptable.

Some metallurgists recommended that 316 should be annealed at $1800^{\circ} \mathrm{F}$ to avoid failure. Too many installations have been made in sodium service without annealing and with 0 to $10 \%$ ferrite without failure to make their recommendation mandatory. 
TUBE TO TUBE SHEET ATTACHMENT

The configuration for the tube to tube sheet attachment of a small Iip $1 / 16^{\prime \prime}$ high with a $1 / 8^{\prime \prime}$ radius curve blended into the face of the tube sheet had been machined on the Inconel face of the tube sheet.

After the tubes had been inserted into the lower tube sheet, they were pinned in place when the sine wave position had been established. The pinning was done by roller expanding the tube approximately $1 / 4^{\prime \prime}$ above the flat face and $3 / 4^{\prime \prime}$ below the face of the tube sheet.

After the upper tube sheet was in place and welded on, the tubes were cut back with an abrasive wheel to an approximate helght of one inch from face of tube sheet. The tubes were then pinned in position as they were in the lower tube sheet. With a $5 / 8$ inch high sleeve all tubes on both tube sheets were then cut with an abrasive wheel. P1cture 8-1-18 shows tubes being expanded into upper tube sheet after preliminary cutting.

All expanded tube inside diameters were taken and compared with precalculated minimum required diameters. Any tubes insufficiently expanded were rerolled. The minimum diameters were constant for most tube holes but larger holes had been noted in the inspection of the drilled tube sheet and the proper min.dia, calculated for each hole. All tubes were within .001" of the same diameters. Therefore, tube OD - tube ID - .004 was calculated as a constant and subtracted from the measured tube sheet hole. If the tube ID after expanding was equal to or greater than this by not more than .006" the expanding was considered satisfactory.

The tube ends were then machined back to the final helght .410 to $.415^{\prime \prime}$ above the tube sheet with a special end mill with a ilmiting stop. The tube ends were then carefully deburred inside and out and then cleaned, first with distilled water and then with acetone. The roller expander had been lubricated with water soluable Lube-A-Tube KS tube rolling compound so it was easy to remove with distilled water. Tubes were cleaned by blowing cotton plugs saturated with acetone through the tubes using nitrogen as the propeliant. Each trepan Iip was visually examined to make sure 1t was snug to the tube. When necessary the tube was rerolled. In some cases the lip curled away from the tube and was made tight by tapping a cylindrical tool, which had a radius ground on the inside, down over the trepan to tighten it externally.

During all operations plastlc caps were kept over cleaned tubes. After all operations had been completed, tubes were cleaned and capped. A support plate was blocked into position against the tube ends on the lower tube sheet to support the tubes when the unit was raised to a vertical position:

A steel cap was made and fitted over the lower tube sheet Including thermocouple plugs and fastened to the steel shell holding ring (shown in picture 8-1-17). This cap protected the lower tube 
sheet, tubes, etc. from damage while putting it in the pit and during welding the upper tube sheet tube attachments.

The unit was then raised vertically in a pit and a scaffold erected around 1t. The fixture for holding the automatic welding gun was put in place and a plastic tent to keep off drafts erected around the unit. This arrangement is shown in pictures 8-1-19, 8-1-20, 8-1-21.

The tube sheet was given a final cleaning and welding started on the root pass. After the root pass was completed, it was dye penetrant inspected, repaired and reinspected. Then the tube holes were plugged with rubber corks and a Mass spectrometer Leak test was run.

The M.S. Leak test Indicated appreciable leakage that could not be located by probe. The tube sheet was then sectioned with plastic and each section tested. The leaks could not be pinpointed adequately by this method.

The shell was then pressurized with nitrogen to $15 \mathrm{ps} 1$ and the tube sheet flooded with acetone and bubble tested. By this means the leaks were located, repaired and the root pass welding was accepted after a confirming $M$. S. Leak test.

The repairs required indicated that it would be preferable to make the first few passes heavier and test after the second pass because there were occasions when the weld metal did not cover the top of the trepan IIp adequately.

As a result of this, the 4 th bead setting was unnecessary. The second and third beads were heavy enough to bring the level of the weld ready for position 5. Refer to page 6-1-18.

After all 14 passes were completed the welds were again penetrant inspected and minor indications were ground out as shown in pleture 8-1-22. As can be seen, the amount of weld metal applied is large as would be expected from 14 passes.

The unit was then lowered, the cap removed from the lower tube sheet and the lower tube sheet raised up for welding. Although two beads were applied before M.S. test there was stili some leaks to be repaired. The same procedures were used as on the upper tube sheet.

After the M.S. test was completed and the roughing pump shut down the vacuum was broken with nitrogen. It was discovered in disconnecting the piping that some vacuum pump oll had gotten into the unit. Less than a cup was drained from the unit and the remainder was removed with a light naptha solvent. See section 5-5-1.

Upon completion of all tube attachment welding and the final dye penetrant test, the unit was lowered for addition of channel heads. 
Comments: The tube joint design used is a highly restrained weld joint. The small curved trepan primarliy elininates the corner between tube and tube sheet which would be difficult to fill completely. When sections of the qualification samples were examined, the top of the trepan was fused over to the tube and in many cases the separation between tube and tube sheet seemed to start level with the face of the tube sheet.

Inconel is a difficult material to weld and frequently has some porosity in the welds. Inconel to stainless transition welds encounter an additional difficulty in the difference in coefficient of expansion. It is probable that a thicker overlay with a deeper and thicker trepan would make the joint more flexible.

Some other manufacturers' experience has shown that great depth of weld in shear is not necessary for a long lasting tube joint. Most fallures seem to start from bending stresses at root of the weld.

The fourteen passes required for this tube attachment are very costly. Even with the automatic gun, time is required to position, clean and run the gun. Exclusive of test and repair time it took 68 shifts to place the 8400 beads.

Research should be done to simplify and improve this attachment. As a starting point, an inconel overlay $5 / 8^{\prime \prime}$ thick should be tried with a $3 / 8^{\prime \prime}$ deep trepan leaving a tapered $11 p$ with with a $.2^{\prime \prime}$ thick base, .15" thick top. The base should blend to the tube sheet with a 1/8" radius. The top of the trepan should have a small Iip approximately $1 / 32^{\prime \prime}$ high and $1 / 32^{\prime \prime}$ thlck. The tube top should be placed approximately $1 / 8$ " above the trepan 11 .

The first pass would be a light TIG weld fusing the $1 / 32^{\prime \prime}$ tip to the tube. All subsequent passes would be TIG with inconel wire filler metal. If an automatic welding gun is used which is similar to that used to weld this steam generator, the first setting should be approximately .075" above the trepan IIp and each setting thereafter approximately .025" higher. Manual welding may give a more varled set of heights but multiple beads would still be required.

It would be desirable to have the bead pattem follow the sketches below, if possible.

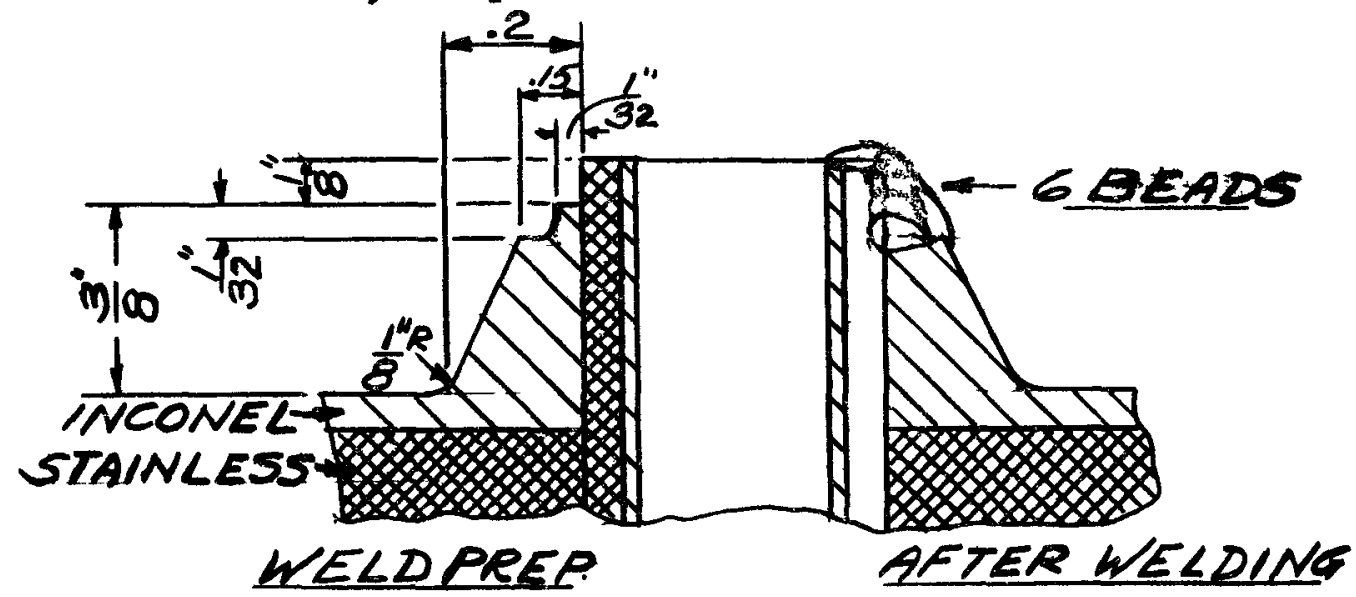


The upper and lower channel heads were cleaned at the weld kerf area and positioned to the respectlve tube sheet weld kerfs which had been cleaned. Support bars were tarked $s n$ fron tube sheet to head.

Stainless portion of the inside weld was dane in accordance with the weld procedure and the outside of the root pass ground back to clean metal and dye penetrant irspested. A radlagraph was taken at this point to confirm the weld quality and reluce the chance of having to make a deep repalr. The support tars were removed before grinding the root pass clean for betteir access.

The outside weld was carried sbout $2 / 3$ of the way up and radiographed. The weld was radiogracked agaj at ihe $2 / 3$ ras point and when the stainless welding had yeen copietej. This progressive radiography kapt the few repalrs very shallow and easy to repair.

The Inconel overlay was then applied to the inslde and final dye penetrant and radiographic inspecticn was completed.

The thermocouples in the upper read were then installed as shown in picture 8-1-24. The steaz cutlat test cover was installed and strain gage instaliation started on both tre srside and outside of the head.

Comments: The use of radiograph as the weld was being built up saved many hours of grindirg asd we ling for repalrs. The radiography was performed on the third sisft when production workers were not in the area since radioactive Iridium 192 was used (see section 4-3-1). Results were ready for tise first stift the next day. 


\section{TIISRMOCOUPLES}

The thermocouple installation was outlined in each section as it occurred because of the necessary sequence of installation. This section is a general description of the thermocouple installation. The thermocouples are delicate and easily broken if bent too sharply or mishandled, therefore, it was necessary to check continuity of the couples at each closure stage when some portion would become inaccessible.

Two methods of checking the thermocouples were used. The first one was used on all thermocouples assembled in the tube bundle (see section 3-1-1). In this case a hot soldering iron was held against the thermocouple end and a mllilvolt meter attached. If the needle started a steady movement the thermocouple was considered good.

The second method was measuring the resistance between each wire and the sheath and the resistance from wire to wire. The latter was tabulated as a record for future continuity checks.

All bends were made with the largest possible radius and the wires held in place with welded on staples formed from stainless steel type 316 bare weld wire (see P1cture 8-1-24).

Thermocouple wires were broken off at the plugs at the lower tube sheet and the steam outlet nozzle. They ware repaired by the procedure given on page 5-4-1, and the continuity was checked to prove thermocouples were in good working order.

Special care was taken in fastering the thermocouple leads to some type of support for protection whlle handling the generator during manufacturing and shipment. Th1s is shown in Pictures 8-1-34 through 8-1-37. This support held the thermocouples securely so they would not be broken from vibration causes by a blast of air or another exciting force. 
Strain gages were applied at locations shown on drawing H-42207-1-22. The metal surface was cleaned with an abrasive wheel and washed with acetone. The gages were purchased with leads attached. aages and type TL-56 terminals were glued to metal with Eastman 910 cement. Gage leads were soldered to terminals. Gages were then checked for resistance to ground with a megohmeter. Gages reading a minimum of 50,000 megohms were considered satisfactory. In some cases 1t was necessary to dry out the gage with a ha1r dryer and heat lamp.

Lead cables from gage terminals to a terminal table were supported on the unit by a clamp bolted to a steel block which was glued to the metal with an epoxy cement. Armored lead cables were used to go to gages inside the upper channel head as shown in pictures $8-1-25,26$ and 27 . The armored cables were brought out through the test cap and sealed by use of a standard compression fitting. The armored cables were "Mineral Insulated Cable Part No. 309/7 SM-1," manufactured by Ceneral Cable Corporation.

All gages and terminals were molstureproofed with wax as show in plcture 8-1-29. Gages and terminals inside the channel head were waterproofed on top of the wax with a thin coating of Armstrong A-2 epoxy cement, followed by three coats of PR-385-M manufactured by Product Research Company of Gloucester City, New Jersey. Each of the se coats required six to elght hours curing time.

Two coats of quick drying Heresol Primer $\mathrm{kC}-9$ obtained from Heresite and Chemical Company of Manitowoc, Wisconsin, were applied over all the other coats. Finally all surfaces were coated with vaseline. Picture 8-1-26 shows internal gages after waterproofing.

In spite of this, some gages falled during the tests.

Gage cables were connected to a terminal table and the recording instruments were connected to the table as shown in picture 8-1-32.

Comments: Strain gages should be applied in dry a1r. High humidity causes grounding.

It is better to add more waterproofing than too little when tests are made at high pressure. Cables must be leak tested before using. The above waterproofing procedure has been used on other vessels with good results.

CoO-1213-27.

Detalls of procedure and results are given in report 
After the hydrostatic tests and all strain gage data had been recorded, the unit was drained on both the shell and tube sides. One end of the unit was raised to assist drainage in a manner similar to that shown on P1cture 8-1-30. Lack of room prevented the unit from being ralsed to the full vertical position which was desired for best drainage. Samples of the distilled water were taken during drainage and the conductivity tested to make sure the unit was oloan.

The unit was then placed in a stress relloving furnace and gas purge lines hooked up to put dry nitrogen through the tubes and shell. The furnace was set to hold a temperature on the unit of $400^{\circ}$ and the temperature at several points along the shell was recorded continuously. The temperature was limited to $400 \mathrm{~F}$ because of the phenol1c type plastic parts of the thermocouple connectors. (P1ctures $8-1-34,8-1-35)$.

It took several days to dry the unit out by this means. A vacuum pump was hooked on to the unit and the unit was alternately pressurized and evacuated in an attempt to speed up the drying. It is not certain that any of these steps helped to a major degree.

It was estimated that approximately ten cubic feet of water was trapped in the baffle and thermal shield structure of the unit. The furnace drying proved that the thermal shield was very effective. At the start the water trapped between the shield and the shell steamed out vigorously. Later the gas space insulated the water trapped inside the shield by the baffles.

When the steam stopped pluming out, the nitrogen purge was checked on a homemade dew point Indicator. Both the bottle gas and the effluent were checked. When the effluent showed a $-40^{\circ} \mathrm{F}$ dew point the furnace was shut off. The purge was continued unt1l the unit had cooled enough to be moved.

The test caps on the large sodium nozzles, the rupture disc nozzle and the steam side nozzles were machined off on a horizontal mill as shown in Picture 8-1-33. The machining was done with great care to avoid letting chips fall into the shell of the unit. After the test covers were machined off, the inside was sealed with plywood and tape as shown, and the nozzle weld kerfs machined.

The unit was given a final cleaning at each nozzle and expanding type seals were placed in each nozzle. See P1cture 8-1-34. The shell side was pressurized with nitrogen and a bottle of nitrogen connected to the unit to maintain pressure in case the vibration of the truck should loosen a seal enough to cause some leakage.

Special care was taken to protect the thermocouple wires as shown in P1ctures $8-1-34,8-1-35,8-1-36,8-1-37,8-1-38$. 
Comments: The drying of the unit can be simplified and made less costiy by moving the unit to a fuliy vertical position for better drainage.

The drying can be further speeded up by taking off all the thermocouple connectors. This would permit funnage temperatures to run much higher, in the neighborhood of 700 to $800 \mathrm{~F}$.

Fxpandable plugs in nozzles are not always rellable. A better shipplng cover for the nozzles would be a cap formed from $1 / 8$ " plate covering the weld kerf and welded to the side of the nozzle with a small fillet weld all the way around.

As noted on page 4-7-1 describing the hydrostatic tests, the change in conductivity of the water was negligible. The minor change from 28 to 31 micromhos can be accounted for by gases dissolved in the water while the unit was under test pressure. This proved that the unit was clean and free of lonizing material. 
SECTION 4

QUALITY CONTROL

$\underline{\text { Page }}$

Inconel Clad Test Procedure

4-1-1

Tube Sheet to Shell Weld Radiography

4-2-1

Head to Tube Sheet Radiography

Examination of Tubes at Guide Rings

Tube to Tube Sheet Weld Leak Tests

Cleaning

Hydrostatic Tests

Drying

4-3-1

4-4-1

4-5-1

4-6-1

4-7-1

4-8-1

Page 4 


\section{INCONEL CLAD TEST PROCEDURE}

1. Apply a few drops of concentrated hydrochloric acid with a dropper to area to be tested, being careful to confine acid to area under test. Allow acid to react with the metal for 1 minute.

2. Apply with a dropper a few drops of a $10 \%$ aqueous solution of potassium ferricyanide.

3. Apply with a dropper a few drops of a $20 \%$ sulphurlc acid solution. ( $10 \mathrm{ml}$ concentrated sulphurlc acld in $80 \mathrm{ml}$ water.)

4. If dark blue color appears Immediately, material is stainless steel. If solution remains essentially colorless changing slowly to light blue, materiai is Inconel.

5. Wash area thoroughly with water.

Notes: To be sure acid has been completely removed area can be swabbed with a solution of sodium carborate or other mild alkali. It is recommended that such a solution be avallable during test in case any acid is spilled on skin or clothirg.

CAUTION: Potassium ferricyanide is very polsoncus and the concentrated acids can cause severe burcs. Test should be conducted by carefully trained personnel of uncer strict supervision. 


\section{TUBE SHEET TO SHELL WELD RADIOGRAPHY}

The weld between the tube sheet and shell on this steam generator can not be radiographed by placing the film on the inside of the weld. At the lower tube sheet, the sodium outlet nozzle is too far away from the weld and the flim would be held away from the weld by the thermal shield. There is the added danger of the f1lm getting stuck in an unretrievable position.

At the upper tube sheet, there are bundles of thermocouple wires which are looped from the guide rings at the tube sheet side of the weld to the thermocouple plugs in the holes on the shell side of the welds. The fragility of the wires made 1t seem undesirable to attempt to place the film on the inside of the weld through the rupture disc nozzle although in all other respects there seemed to be adequate access.

The technique described below using a radioactive source, Iridium 192, Inside the tubes in the outer row, 5-1/2" from the outside of the sheli, gave satisfactory sensitivity. A shot was made from every other tube, 1.e., 36 shots. The technique worked so easily shots were taken after the manual welding was completed and half way up the submerged arc welding as well as the finished weld. The intermediate shots reduced the depth of repalrs and made them easier to locate.

A mock-up was made to prove the sensitivity of the technique and acceptability of placing the penetrometer on the outside of the weld.

A $1-1 / 4^{n}$ thick stainlegs steel plate with 1.2 ASME penetrometer on source side and a .62 ASME penetrometer on the $11 \mathrm{~lm}$ side was shot using a $1 / 4^{n}$ backing lead over Eastman Kodak type $\mathrm{M}$ fIlm with lead screens.

A piece of scrap tubing from the steam generator was centered $5-1 / 2^{\prime \prime}$ from the film side of the plate. 45 curies of Iridium 192 with $1 / 8^{\prime \prime}$ diameter by $1 / 8^{\prime \prime}$ long dimensions were used at an exposure time of 50 seconds. Film development was 8 minutes at $68^{\circ} \mathrm{F}$ for a density of 2.5 to 2.6 .

This procedure was used on the unit with only the film side penetrometer in accordance with ASMB section VIII, paragraph UW-5I, subparagraphs $e 1, e 5$, and 1 . This technique gave a sensitivity of $2 \%$. 
The head to tube sheet weld was radiographed using a 45 Curie Iridium 192 source with the source placed on the longltudinal axis of the unit and a single exposure for the entire girth weld.

Radlography was performed as the weld was being built up to reduce repair time and make defects easier to locate. This sequence of welding and radiographic inspection is described on Page 3-6-1. 


\section{EXAMINATION OF TUBES AT GUIDE RINGS}

During fabrication of the tube bundle the roller expander tools showed serious wear. Several times the tool broke and in some cases the parts had to be removed with nitric acid. This problem is discussed on Pages 3-1-3, 4, 5 and 6 in detail. It was decided to complete the innermost row of tubes and all the four outer rows by tack welding the tubes to the guide rings.

Because of the possibility of damage to the Inconel liner in the tubing either by the expanding operation or tack welding, all tubes were inspected on the inside surface in the guide ring area using a Boroscope. The Boroscope produced a magnified 1mage approximately 4 to 1. A Polaroid camera was used in confunction with the Boroscope to obtain a pictorial record of the most serious conditions found in the visual examination.

The pictures included here are approximately 10 to 1 magnifications of the surface conditions. Faults or texture of the surface is further enhanced by the incidence angle of the lighting supplied by the Boroscope bulb ahead of the lens. The shadowed effect on a portion of some of the pictures occurred when the Boroscope was close to the surface. This was hard to control and not consistent from picture to picture. The variation in distance to the surface changed the magnification of the picture and the lighting effect on the texture of the surface.

The first 12 figures are made from sample surfaces or tubes to give a comparison between Boroscopic pictures and direct observation or measured marks. 


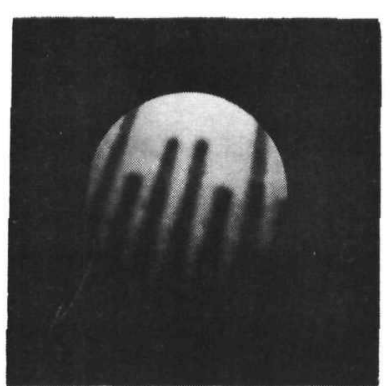

Figure 1

.010 INCH SCALE

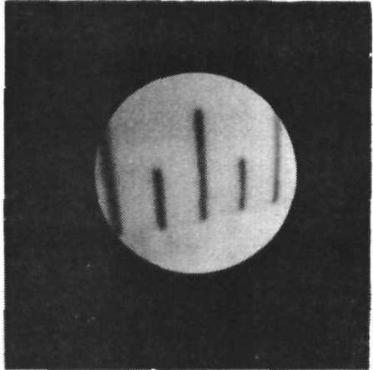

F1gure 2

.020 INCH SCALE

\section{BOROSCOPIC PICTURES OF A PLASTIC SCALE}

On Figure 1 the .010 inch scale reads about . 15 inches center to center of the two center marks and .65 inches for the five spaces or center to center of the long divisions on each side. Approximate magnification 13 to 1.

On Figure 2 the .020 inch scale was measured at .0206 inches between divisions but in Figure 2 the left side divisions measure .2 inches while the right side divisions measure . I5 inches. This would indicate that the scope lens was not perpendicular to the scale. Approximate magnification between 9 and 10 to 1.

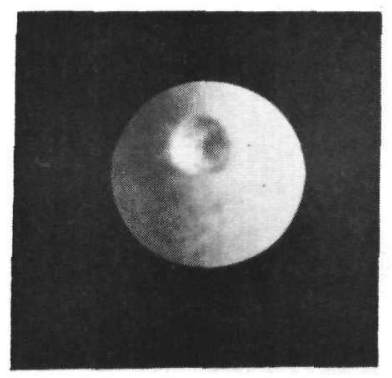

Figure 3 $.015^{\prime \prime}$ DIA . $\mathrm{x}$ $.0055^{\prime \prime}$ DEEP

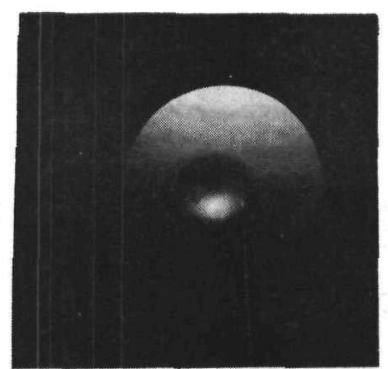

Figure 4 .029 " DIA . $\mathrm{x}$ $.010^{\prime \prime}$ DEEP

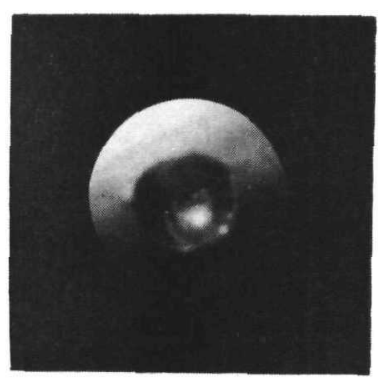

Figure 5

.043 " DIA. $\mathrm{x}$ $.015 "$ DEEP

BOROSCOPIC PICTURES OF PUNCH MARKS ON SURFACE

These punch marks were measured on the surface as noted under each figure. The measured diameters on the pictures are Figure 3-.2", approximate magnification 13 to 1 ; Figure 4-.29", approximate magnification 10 to 1 ; Figure 5-.43", approximate magnification 10 to 1.

On the basis of these pictures it would seem reasonable to assume an average of 10 to 1 magnification for the subsequent figures. 


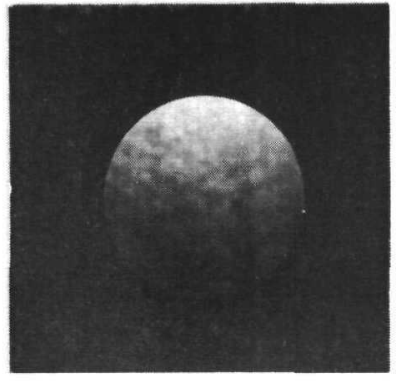

Figure 6

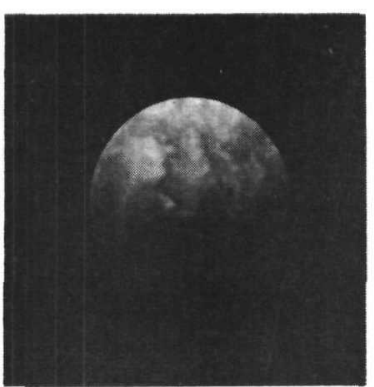

Figure 7

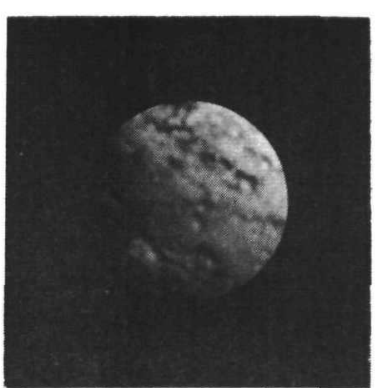

Figure 8

Figure 6 The tube surface shown here appears relatively smooth to the eye but the angled lighting and magnifying effect of the Boroscope shows some texture.

Figure 7 The surface here has very shallow working in which a very thin layer of metal has been pressed with the roller leaving an edge or wave crest.

Figure 8 Pleces of the surface have been gouged or pressed out leaving shallow pits $.005^{\prime \prime}$ to .01" in diameter probably $.002^{\prime \prime}$ deep.

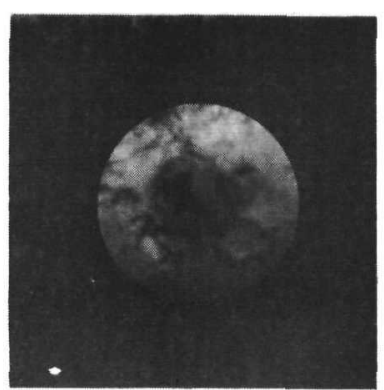

Figure 9

CRATERING

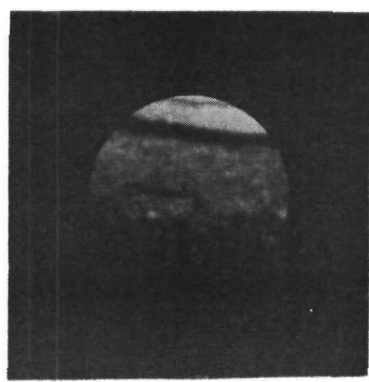

F1gure 10

CRACKING

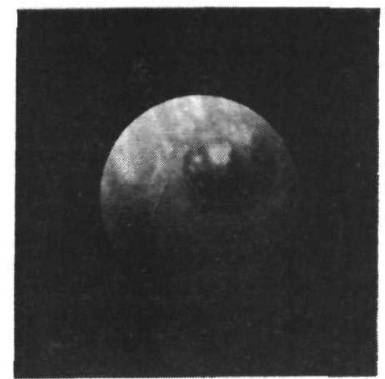

F1gure 11

FUSE-THROUGH

Figure 9 Larger flakes of material have been gouged out leaving craters .010" to .020" in diameter by .005" deep.

Figure 10 The cracking shown here appeared primarlly at the edge of roller expanded sections where the inside of the tube is enlarged by the rounded shoulder of the rollers. The metal does not always flow smoothly and blend in.

Figure 11 This shows the typical round spot stain of oxidation from heat with an inward buige. When polished with a rotating emery cloth the bulge top takes on a highlight shown here and in the other flgures showing tubes with fuse-through. 


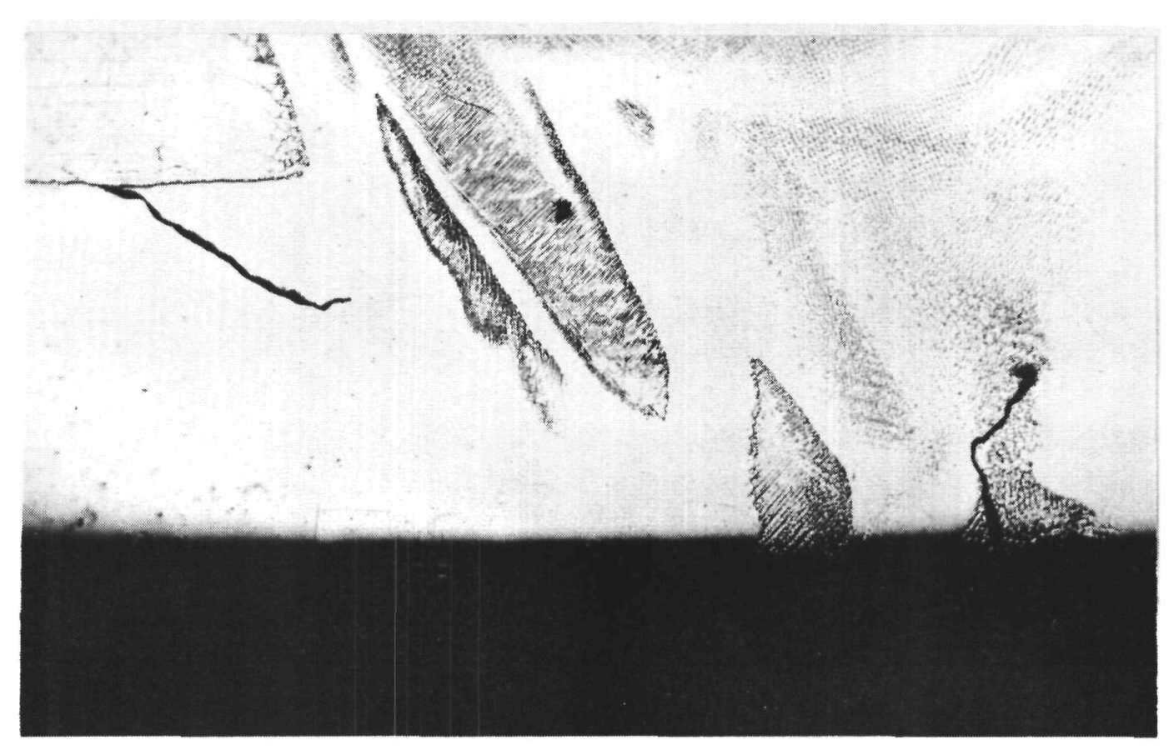

Figure 12

PHOTOMICROGRAPH OF SECTION OF FUSE-THROUGH IN FIGURE 11

This photomicrograph taken at 100 times shows the solution of Inconel and stainless steel to some intermediate alloy. This evidence of possible solution was cause for refection of any tube having the signs of a probable fuse-through.

The horizontal line approximately l" long on the upper left hand corner of the photomicrograph represents the interface between Inconel below the line and stainless above the line. To the right of this horizontal line the Inconel and stainless are alloyed together. The black at the bottom is the inside of the tube. The stainless part of the tube extends on above the top of the picture. The actual thickness of the Inconel in this portion of this tube was .025 inches. 


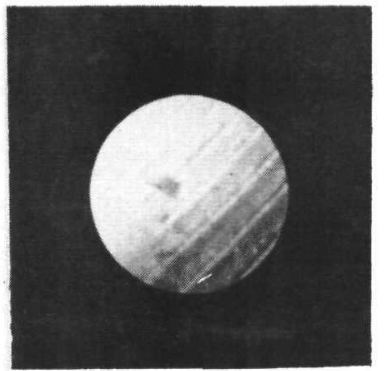

Figure 13

ROW 1, TUBE 120

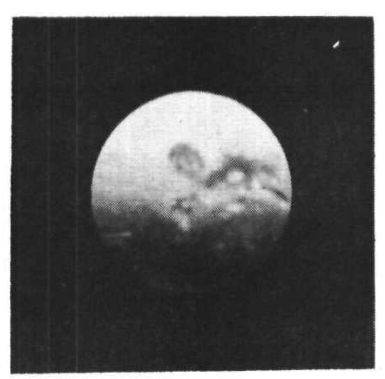

Figure 14

ROW 1, TUBE 102

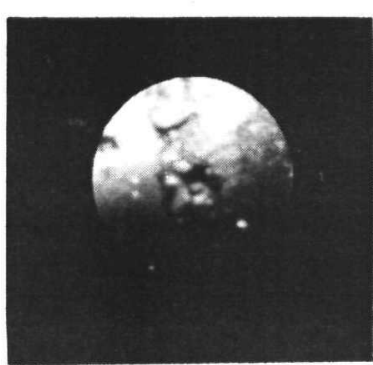

Figure 15

ROW 1, TUBE 218

Figure 13 Shows a crested wave effect produced by an imperfection starting to develop in the roll. The Inconel is pressed out leaving very shallow crest. The rolls did not appear to be damaged but may have had an imperceptible flat.

Figure 14 This shows a tube with pits .01" in diameter and an area of pit-crater .01" x .03". These are probably .003 to $.005^{\prime \prime}$ deep.

Figure 15 A crater .015" in diameter $x .005^{\prime \prime}$ deep and a crackingfeathering condition similar to Figure 10 and 2. 


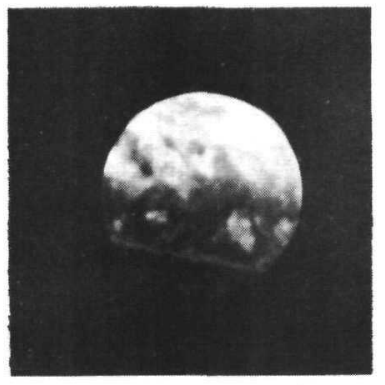

Figure 16

ROW 1, TUBE 145

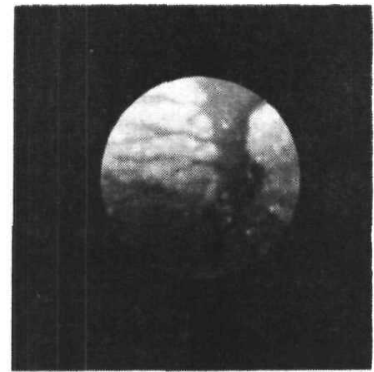

Figure 17

ROW 1, TUBE 145

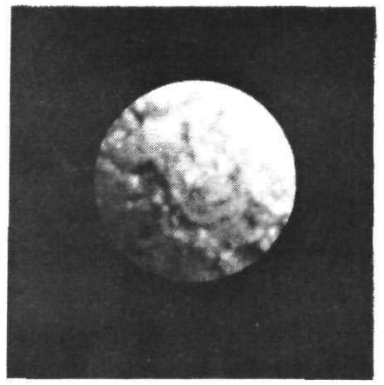

Figure 18

ROW 1, TUBE 226

Figure 16 Pitting and feathering are shown in this are to be approximately .01" diameter x .003" deep.

Figure 17 In the same tube cracking .02" wide is found with flaky feathering adjacent to the crack. Cracking is very shallow.

Figure 18 Pits .01" wide adjoining each other give the appearance of cracking. Pits are about .003" deep.

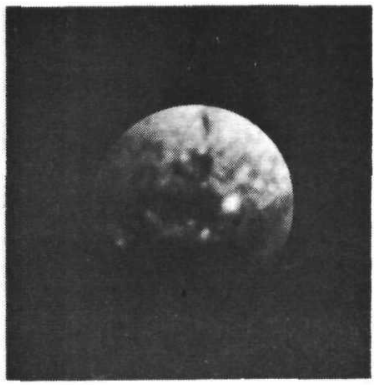

Figure 19

ROW I, TUBE 228

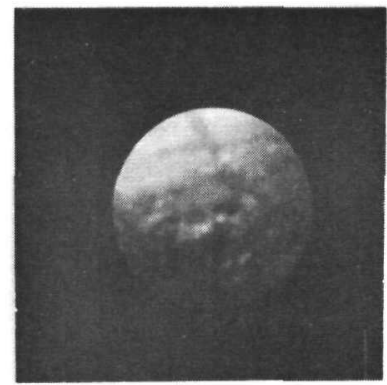

Figure 20

ROW 1, TUBE 228

Figure 19 Cratering appears quite large in the center of the picture approximately .03" in diameter. A shadow pattern is not evident so the crater may have dirt in it.

Figure 20 Appears to be the same location after a light polish showing pits about .01" in diameter $x .005^{\prime \prime}$ deep.

The figures shown above were all damaged in the roller expanding operation. All damage appeared to be .005" deep or less and it was recommended that the tubes be used. 


\section{FUSE-THROUGHS}

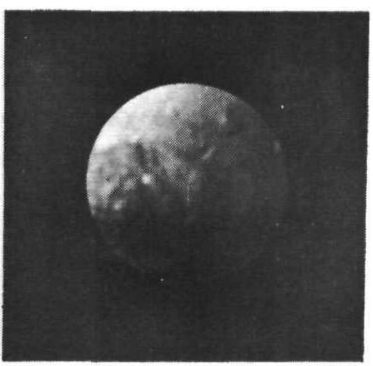

Figure 22

ROW 1, TUBE 213

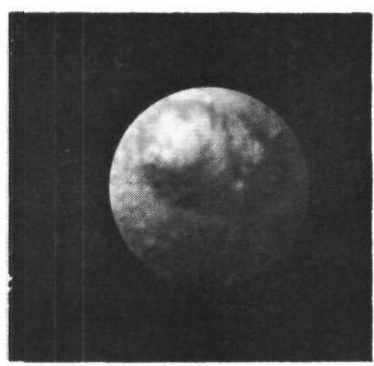

Figure 22A

AFTER IST POLISH

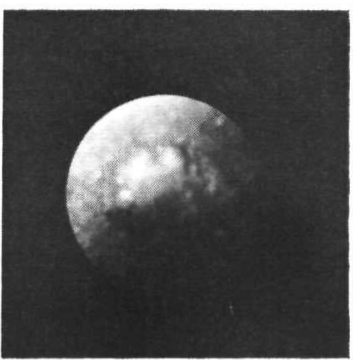

Figure $22 \mathrm{~B}$

AFTER 2ND POLISH

The first figure shows the typical dark oxide stain and highlights toward the lighted side of a bulge from a fuse-through. The highlights from the two polishes occur on the center or high point of the bulge confirming this diagnosis. The discolored spot appears to be .04" wide $\mathrm{x} .07^{\prime \prime}$ long.

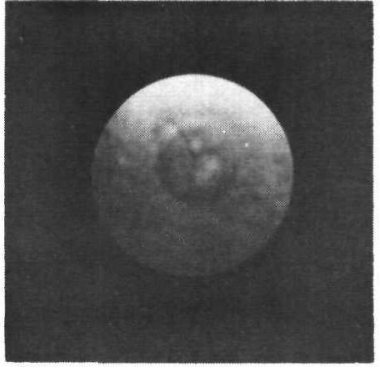

Figure 23

ROW 4, TUBE 299

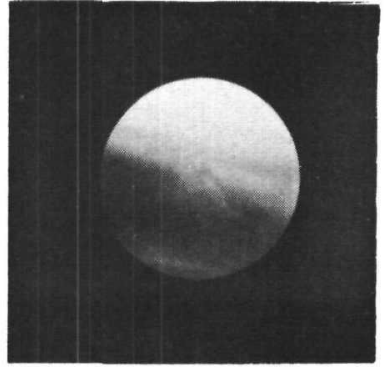

Figure 23A

AFTER IST POLISH

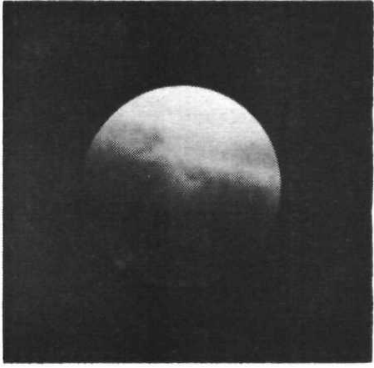

Figure 23B

AFTER 2ND POLISH

The first figure shows the dark oxide stain, the highlight on the lighted side and a probable crack. The diameter of the stain is .035" and crack length .02". The two polishes showed that the bulge was negligible but the crack was actually .03" and a probable cause for future failure. 


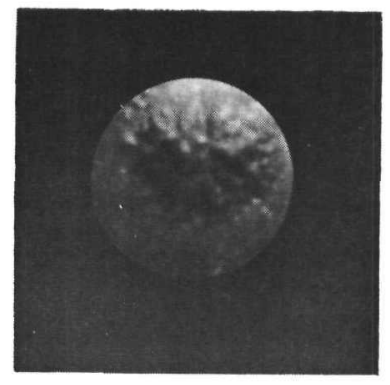

Figure 24

ROW 1, TUBE 208

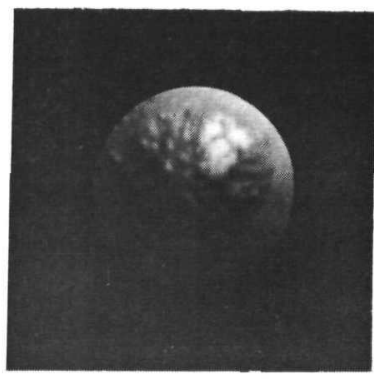

Figure 24A

AFTER POLISH

The first picture shows the dark stain and highlight on the lighted side of a bulge. There appeared to be a three directional crack associated with a small pit in the roughened surface. The polish fortunately hit on the top of the bulge and the crack. It was felt that this crack would be potential failure. In the preliminary hydrostatic tests of the unit, this tube had a small leak. It is presumed that the leak was through this crack.

In view of the two apparent cracks in the fuse-through area and the photomicrograph showing the probability of the deterioration of the Inconel cladding it was decided to plug these tubes at the tube sheets. 
After the root pass of the tube to tube sheet attachment wells were made a dye penetrant inspection and Mass Spectrometer Leak test was required. This pattern was followed on the upper tube sheet but later on the lower tube sheet the tests were made after the second bead had been applied. See section 3-5-1.

A Stokes vacuum pump was connected to the shell side of unit through a $3^{\prime \prime}$ Iine to one of the large nozzles in the pit. (For upper tube sheet test - the sodium outlet and for lower tube sheet the rupture disc nozzle.) The Mass Spectrometer was connected to a small connection at the tube sheet. (A vent nozzle for the upper tube sheet and the drain nozzle for the lower tube sheet.) The calibrated leak was connected to another opening in the upper tube sheet and to the sodium outlet nozzle on the lower tube sheet.

The tubes had to be plugged with rubber corks on the upper tube sheet because the hellum could leak down through the tubes to the lower tube sheet and back through the small space between the tube and tube sheet into the shell.

The roughing pump pulled the vacuum on the shell quite readily for a shell of this size. During tests the roughing pump was shut off. Whenever the vacuum was broken, 1 t was broken with dry n1trogen.

The first test was made with a plastic sheet covering the tube sheet and taped to the tube sheet weld kenf. Helium was introduced under the plastic by a hose. When leakage rate was found to exceed the specirlcations an attempt was made to probe for the leaks but they could not be pinpointed. Then the tube sheet was divided into sections by taping plastic to the tube sheet. The most that was accomplished by this was to determine that there were leaks in many of the sections.

The shell was pressurlzed with nitrogen and the tube sheet flooded with acetone. Careful observation plcked up enough leaks which were repaired to enable a subsequent test to be passed.

Response time was fairly rapid with this arrangement.

The acceptance level for the leak tests was a maximum leak rate of $5 \times 10^{-7} \mathrm{stid} . \mathrm{cc} / \mathrm{sec}$. The first tests on the upper tube sheet were accepted at $3.3 \times 10^{-6}$. Then after the lower tube sheet tube attachments were welded the lower tube sheet tests were accepted with a $7 \times 10^{-8}$ leak rate. The upper tube sheet was rerun after all tube attachment welding was completed and accepted with a leak rate of 4.56 $x$ 10-7. The specified leak rate is practical but only after both ends are sealed with satisfactory welds with two or more beads. 


\section{CIEANING}

As a general pattern all cleaning was done at each stage of assembly when it was convenient to remove heavy dirt or o11 and again a final cleaning fust before the part or area would be made inaccessible.

The prime clearing agent was acetone and all parts were wiped with acetone in the course of assembly. The tube outside surface was wiped with acetone and then handled with white gloves during final assembly of the bundle. The inside surface was cleaned after roller expanding with cotton balls saturated with acetone propelled through the tubes with dry nitrogen.

As much as possible the tubes and nozzle openings were sealed with plastic caps or taped on covers. The photographs in Section 8 show the nozzle and tube protection at various stages.

The only other cleaning fluid was the light naptha used to remove the vacuum pump ofl (Section 5-5-1). This naptha could be used instead of acetone throughout and is less expensive.

During and after removing the test caps from the nozzle great care was taken to avoid contamination of the inside of the unit with chips and abrasives. Before placing the expanding seals the inside of the nozzles were wiped with acetone.

Removal of o1l, water and other volatile contaminants is necessary to obtain the high vacuum required for the Mass Spectrometer Leak test. 


\section{HYDROSTATIC TESTS}

1500 gallons of distilled water was purchased. A portable conductivity meter was taken to the vendor's plant and the conductivity checked as the cleaned stainless steel tank truck was filled. The truck had been cleaned by the truck company, and in addition, it was rinsed out with distilled water. The rinse water conductivity was checked before and after rinsing and found constant.

As the unit was rilled it was tipped as shown in P1cture 8-1-30 to aid in venting. Samples of water were taken during filing and checked for conductivity. Throughout the whole process the conductivity remained constant and identical to that measured at the vendor's plant.

During the application of the test pressures it was noted that the unit still had an appreciable amount of air which could not be vented. This appeared to be in the order of 8 to 12 cublc feet.

After applying the test pressures and completing all the strain gage tests the water was drained and again several samples tested by conductivity meter. The water conductivity change was very small and could well be caused by dissolved gases forced in under the high pressures.

The conductivity readings were 28 micromhos at $86^{\circ} \mathrm{F}$ at loading and 31 micromhos at $68^{\circ} \mathrm{F}$ at draining. The vendor supplied an analysis of the distilled water showing that a corrected reading for gases would be 8 micromhos and the total solids less that 2 PPM.

The detalls of the hydrostatic test pressures and strain gage tests are given in the Strain Gage Test Report C00-1213-27. 


\section{DRYING}

The method of drying the unit is given in Section 3-9-1, Preparation for Shipment. The specification requires that the unit be dried to a $-40^{\circ} \mathrm{F}$ dew point. This dew point mist be reconfirmed after the unit has been allowed to stand for 8 hours outside the furnace.

To check the dew point a homemade dew point indicator was used. A large funnel with a mirror finish was sealed at the spout. The funnel was supported in a large beaker by a plece of plywood which also held a rubber hose and glass elbow.

The effluent purge gas from the unit was directed against the side of the funnel by the glass elbow. The funnel was partially filled with absolute alcohol and small pieces of dry ice were added. The mixture of dry 1 ce and alcohol was stirred with a metal dial indicating thermometer.

When the spot opposite the elbow remained clear of condensation so that the image of the glass nozzle could be seen on the funnel surface, the gas was considered dry.

The tests showed that the nitrogen had a dew point below $-60^{\circ} \mathrm{F}$ and the effluent gas was show to have a dew point below $-54^{\circ} \mathrm{F}$. 


\section{SECTION 5}

\section{REPAIR PROCEDURES}

Page

Guide Ring Hole Relocation

$5-1-1$

Tube Hole in Tube Sheet Repair

$5-2-1$

Inconel Overlay in Head Repair

Thermocouple Wire Repair

Vacuum 011 Removal

5-3-1

5-4-1

5-5-1 


\section{QUIDE RING HOLE RELOCATION}

1. Prepare an end mill to cut a hole .616" plus or minus $.001^{\prime \prime}$ in diameter.

2. With guide ring on a boring mill, center end mill on existing hole centerline then move head in direction marked on ring the measured offset as tabulated in inspection procedure outlined on page 2-5-1. Then bore the hole.

3. Using 5/8" OD 16 BWG stainless steel type 304 or type 316 tube prepare special tubes $1 "$ long, .537" ID plus or minus .001". These tubes were then turned to give a .001 to .0015" interference fit with the holes milled in the ring.

4. Chill tubing in dry ice and arbor press into ring hole.

5. Recheck hole alignment with tube sheet as on page 2-5-1.

6. Two very small TIG tack welds were made, one on each side of tube, to prevent future loosening.

NOTE: Tube bushings might have been roller expanded into ring, but it was felt that roller expanding would probabiy distort rings by bulging the sides. Step 6 may not be necessary but is added insurance. 


\section{TUBE HOLE IN TUBE SHEET REPAIR}

On the upper tube sheet measurements of tube holes shored that hole No. I in row 4 and hole No. 27 in row 2 were sufficlently out of tolerance in diameter as to require repair. Both holes had enlarged between $I$ and 3 inches below the Inconel overlay to $.564^{n}$ for hole 27 row 2 and . $581^{\prime \prime}$ for hole 1 row 4 . Therefore 1 was necessary to repair the hole down near the middle of the tube sheet.

\section{Repair Procedure}

1. Enlarge hole to $.626^{\prime \prime}$ plus or minus $.001^{n}$ by either boring or reaming. Hole finish should be 63 RMS or better.

2. Counterbore tube hole on Inconel overlay side to a depth of $1 / 2^{\prime \prime}$ (approximately 1/8" below inconel overlay). The counterbore should be at an angle of $37-1 / 2$ degrees with the axis of the tube hole.

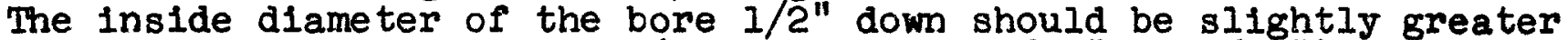
than the tube hole diameter (approximately .630" to .632"). The bottom of the counterbore should be essentialiy perpendicular to the tube hole axis and blend to the angle surface with $21 / 32$ to $1 / 16^{\prime \prime}$ radius.

3. Take a tube, nominal 5/8" OD 16 BWG type 316 stainless steel (OD should be .625" minus .002" plus nothing), and cut tube length $1 / 2^{n}$ less than the thlckness of the tube sheet. ace tone.

4. Clean tube hole in tube sheet and tube thoroughly with

5. Push tube into hole until it is flush with the bottom of the counterbore.

6. Use a roller expanding tool with electronically controlied torque to expand the tube 1ato tube sheet. Make certain that roller expander has been completely cleaned with acetone and is free of wear and pitting. Set the expander control for a "hard roll." (Hard roll setting should produce 3 to $5 \%$ reduction in wall thickness of tube.)

7. Rebulld Inconel overlay over tube and counterbore using sequence \#2 style 10 weld from welding procedure (page 6-1-8).

8. Dye penetrant inspect root, intermediate and final pass.

9. Enlarge tube hole to drawing dimension $.537^{n}$ plus or minus $.002^{9}$ by boring or reaming.

On hole 27 row 2 a counterbore for step 2 was made on the stainless side of the tube sheet in error and was repaired by this procedure. The .626 ID hole had been drilled in step 1 . 
A. A plug was made from a piece of 5/8" OD 16 BWG type 316 tubing by closing it with weld metal at one end. The plug was $1 / 2^{\prime \prime}$ long.

B. Plug and tube hole were cleaned with acetone and the plug inserted into tube hole with closed end of plug facing out.

C. With tube sheet at a minimum temperature of $70^{\circ} \mathrm{F}$ the root pass was welded with TIG using 1/16" diameter type ER-316 filler metal, 9-11 volts, 75-150 amps and 30 CFH argon flow. Root, intermediate and final passes were dye penetrant inspected.

D. Weld buildup was completed as in step $C$ above.

E. Plug was drilled out and hole reamed to $.626^{\prime \prime}$ ID ready for step 3 of procedure for repair. 


\section{INCONEL OVERLAY IN CHANNEL HEAD REPAIR}

As noted on page 2-7-1, chamfer grinding of the intersection between the steam outlet nozzle and the upper spherical head uncovered a crack which was followed down about $1 / 2^{h}$.

The test for Inconel, see page 4-1-1, showed 1 t to stop at the stainless steel.

The ground out area was refilled with TIa welding using $1 / 16$ " Inconel wire with dye penetrant inspection after root, intermediate and final layers. Weld was ground smooth to blend with rest of overlay. 


\section{THERMOCOUPLE WIRE REPAIR}

At several times during the course of fabrication thermocouple wires were broken off near plugs and were repalred. The repair of these wires and the $1 / 16^{\prime \prime}$ oD sheath is a delicate job requiring extreme care.

Photograph 8-1-35 shows original thermocouple boss at top of picture and repaired boss at lower right hand comer.

1. The sheath was flled open for a half lnch by fling flat across the cylinder and laying open the powdered insulation. The two wires were drawn up out of the way.

2. Then a circumferential cut was filed with a fine file at the end of the opening so that the remaining sheath could be snapped off. All three thermocouples in a plug set were done to this point.

3. A speclal sleeve had been prepared with a disc at one end with three holes slightly larger than the sheaths which was slid over all three sheaths disc first with the open end toward the plug.

4. One ceramic bead was placed over one wire on each sheath to separate the wires and the bead and wires cemented into position with Sauereusen Electrotemp No. 8 cement, which was allowed to dry.

5. The wires were checked for an electrical short to each other or to the sheath.

6. The OD of the plug was turned down with a special cutter tool for a half inch. The od of the turned portion was about $1 / 16^{\prime \prime}$ over the outside of the sheaths and sheath welds.

7. Opposite each sheath a flat was ground part way with a grinding wheel. The flat was then continued carefuliy with a fine file until the insulating powder was exposed. The wires were pulled part way out. The center of the plug was cut off with a hacksaw. Then a ceramic bead slipped over one wire. The wires were then cemented in part way with the Sauereisen cement.

8. The wires were checked for shorts and grounds.

9. Since one wire was magnetic and one non-magnet1c, it was easy to determine which wires were to be welded together. The welding was done with a Baldwin Model 34 strain gage resistance welder with a Hughes VTA 54 tweezer welding handplece.

10. The wires were carefully kept separated and were insulated and positioned with the Sauereisen cement. Again an electrical check was made for shorts and grounds. 
11. Sauerelsen cement was used to build up a falrly solid cement block between plug and sheaths. Then the sleeve was moved down the sheaths and on to the plug where it had not been machined.

12. The sleeve was TIG welded to the plug and the sheaths were silver brazed in the holes in the disc at the end of the sleeve making a fairly rigid and strong cover for the repaired joints.. Again all thermocouples were checked for shorts and grounds. 
VACUUM PUMP OIL REMOVAL

After completing the mass spectrometer leak tests on the lower tube sheet, a small amount of vacuum pump oll was found in the piping and in the unit. Less than a cupful of o11 was drained from the three openings to the shell slde on the upper tube sheet. The oll was cleaned out of the shell side of the unit in the following manner.

1. Special Light Naptha AMSCO-SOLV B-85 was used as a solvent. A cover gas of nitrogen was maintained in the vessel at all times. One-half a drum, approximately 27 gallons was pumped into the vessel while it was still vertical through one of the drain nozzles. The fluid was circulated for 20 minutes and drained.

2. The rest of the drum was pumped in and clrculated for 30 minutes and drained.

3. A full drum of fresh solvent was pumped in and recirculated for 30 minutes and drained.

4. The fourth rinse was again a full drum of fresh solvent, pumped and recirculated for 45 minutes.

5. Samples taken from steps 3 and 4 were examined. Samples evaporated at room temperature from a watch glass left no film. Drops placed on clean Wattman filter paper left no discoloration after drying. readily. Examination of the vessel interior showed no evidence of contamination.

CAUTION: Nitrogen cover gas is necessary because of high volatility and explosiveness of the solvent.

AMSCO-SOLV B-85 is a product of American Mineral Spirits Co. Residue remaining upon evaporation would be approximately $.0006 \%$. The chlorine content is guaranteed at 10 parts per million maximum as a chloride. There is no free chlorine in the product. Typical analysis is $84 \%$ aromatics, $4 \%$ naphthenes, $12 \%$ parafines. Initial boling point is $286^{\circ} \mathrm{F}$ and ASTM End Point $340^{\circ} \mathrm{F}$. A check analysis for chlorides by W. B. Coleman and Co. Indicated the total chlorides were less than 10 PPM.

W. B. Coleman and Co. analyzed the vacuum pump oil for chlorides and found .034\% (340 PPM). 


\section{SECTION 6}

WELDING PROCEDURES

Page

Sheet 1

6-1-1

Sheet 2

$6-1-2$

Sheet 3

Sheet 4

$6-1-3$

Sheet 5

Drawing

Drawing

Drawing

B-42207-1 Styles 1-4 *

$6-1-4$

$6-1-5$

B-42207-1 Styles 5-8

$6-1-6$

$6-1-7$

$6-1-8$

Drawing B-42207-1 Styles 12-16

$6-1-9$

Drawing B-42207-1 Styles 17-21

6-1-10

Drawing B-42207-1 Styles 22-26

$6-1-11$

Drawing B-42207-1 Styles 27-28

$6-1-12$

Drawing B-42207-1 Style 29

Drawing B-42207-1 Styles 30-32

$6-1-13$

$6-1-14$

Draw1ng B-42207-1 Styles 34-37

$6-1-15$

Drawing B-42207-1 Style 3A *

Drawing B-42207-1 Style 9A *

$6-1-16$

Drawing B-42207-1 Style 33 Sketch

$6-1-17$

$6-1-18$

Style 33 Machine Operating Instructions

$6-1-19$

Style 33 Machine Operating Instructions

$6-1-20$

Style 33 Machine Operating Instructions

$6-1-21$

Style 33 Table Welding Conditions

$6-1-22$

* Alternate Submerged Arc Procedures 


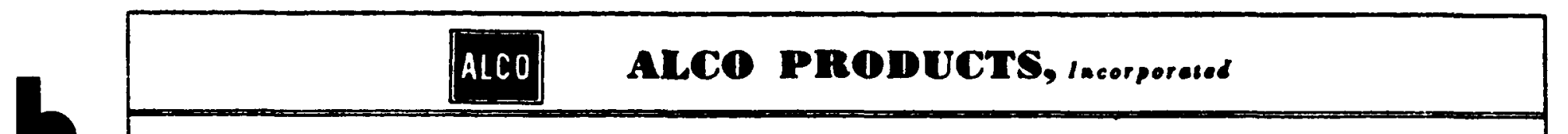

\author{
WELDING AND METALLURGICAL DEPARTMENT \\ PLANT NO. 3 \\ DUNKIRK, NBW YORK
}

\begin{abstract}
WELD PROCBDURE SPECIFICATION
FOR

SODIUI TO WATER STEAM GBNERATOR
\end{abstract}

PREPARED BY

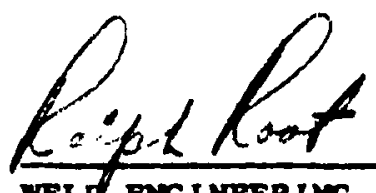

WELd EAGI KEERINO DBPT.
DATE

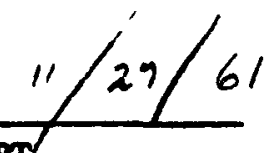

APPRONED BY

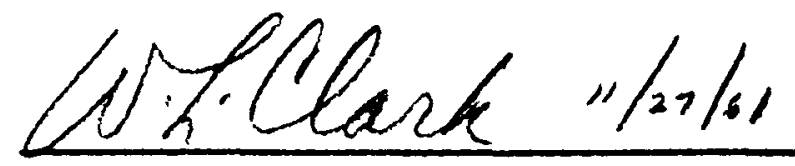

CHIE WELD \& MET. ENO.

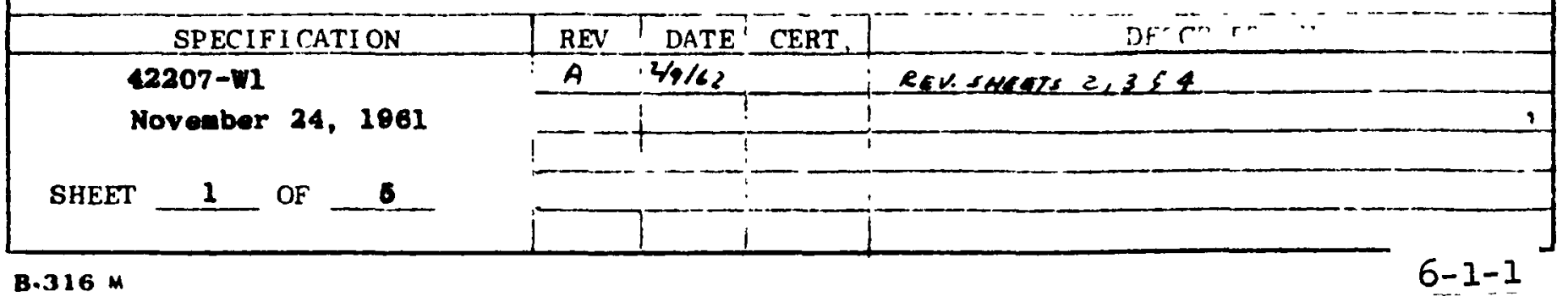


I. SCOPE

Thls speciflcation covars all welding to be perfomed in the construction of sodiun-to-wator type stean generator components.

II . RETERBPCES

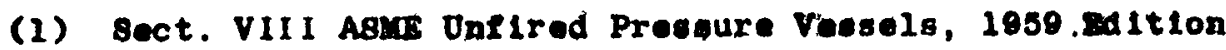

(2) Sect. IX ABUB Welder's Qualleloations, 1950 Bdition

(3) ASur Boller and Preseure Vassel Code Case Interprotations

(a) Case 1270 - Generel Requirenente for Nuelear Veseele

(b) Case 1275 - Muclear Reactor Vessels and Primary Vasaela

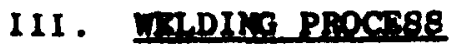

The welding shall be performed by one or more of the following procesese:

(a) Manuel wetal arc reforrod to in weld tables as (M.A.)

(b) Inort cas shlelded tungsten arc with a consumable backing ring or added p1ller, referred to as (TIG)

(c) Inert gas ablelded metal aro with a consumable electrode referred to as ( $Y I O$ )

IV. BASE METAL

The base notal aholl be atalnless steel, Type 316, Type 304, end Inconel, conforning to one or nore of the applicable Sodium laterial specifleationa.

\section{v. EILLER MITAL}

(1) Ceated alectrodes for manual motal arc welding shall conform to ASTX Spacification A-298-55T for Typas E308-15 and B316-15 and/or aodifled Type 316 electrodes referred to as $16 \mathrm{Cr} .-8 \mathrm{N1.-2}$ Mo.

(2) Pare vire flller watal and consumable insert wetal shall conform to ASTM-A-371-53T for Types ER308, ER316, and/or modil1ed Type 316 wire reforred to as $16 \mathrm{Cr},-8 \mathrm{NL} .-2$ Mo. and to MIL-E-21562 modilled for Inconel 82 (BPe7) wire.

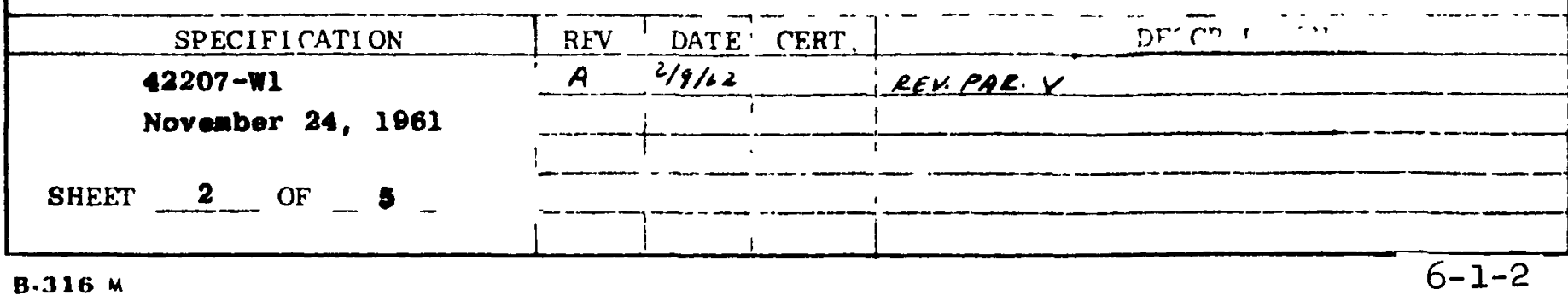




\section{ALCO ALCO PRODUCTS, Iacorporated}

v. FILIER METAL (Cont.)

(3) Covered electrodes shall be dry when used. Covered electrodes shall be used within eight (B) hours of resoval frem the ealed recelving contaliner or shall be plaoed in a veated electric holding oven malntelned at $150^{\circ}$ Y to $250^{\circ}$ Y for elebt (s) hours. The electrodes removed from the holdine oven sbili be used within 1ght (8) beura. Électrodes whlch have com in conteot with water or have the contins danaged shall not be used.

(4) All welding on Type 316 stalniess unterlal sball be carrled out using lilier wire which w11l aseure a wold depeelt of 1 to $3 \%$ delta ferrite content based on the cbenical equivalente epplied to the schnefsler diagran.

\section{v1. BAgE YMTAT PMPARATION}

The edgee or surfaces of parte to be velded shall be propered by maohining, chlpping, or crinding. All jelnte and adjecent base astal (at least $1 / 2$ inch from the groove edge on botb sides) shall be free of soule, paint, 011, erease and weld oontaniante.

\section{vII. PUROLE GAS}

The Inert gas used for shielding and back-up (pursing) shall bo of widlne grade Argon ( $99.00 \%$ purity), and shall be employed at él1 tiace while whlding 18 beins performed by TIO nethed and mot reain on until the wetal has coeled to 350 \%.

\section{TACX VITDS}

Tack wolds shall be as small as practical, and shall wre uniformly with the base notale. All tack welds in jelnts shall be thorouphly cleaned of lag or colde prlar to welding. Cracked tacke shall be completely removed. Temporary tacks used to allgn the jelnte and arc otrikes outside of the grooves shall be removed.

Ix. BOsition or Ixpino

In all instances practicable, the assemblies shall be anipulated for deposition of welds in the flat position. A alnidui of welding shell be done in the hor 1zontal, vertical and overbead positions.

\begin{tabular}{|c|c|}
\hline SPECIFICATION & REV DATE CERT I \\
\hline $\begin{array}{l}\text { N2207-WI } \\
\text { Novenber 24, } 1961\end{array}$ \\
SHEET 3 OF 3
\end{tabular}




\section{ALCO ALCO PRODUCTS, Incorporased}

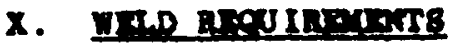

(1) All elac, llux and weld spattor aball be remored fron each weld bead and surface of the groove edges prior to depoeition of the naxt weld bead. Manual or power wire bruablng shall be done wlth a brush having austenitic otalnieas ateel bristles.

(2) Interaediate weld boads ohall erge amoothly and uniformly with the adjaoent bead and/or base astal.

(3) The finlebed welda shall be surflolently snooth and uniform or cround to provide a autiable condition for radiographic inepeotion.

(4) Any cracka, blowholes, or other defecte shali be renoved prlor to depositing the noxt weld bead.

\section{X1. MTDING MUIPIPYT}

Fleotrlo aro welding equipment oball be used and oball be D.C. (DIrect Current) coneletent with the procens and flller motal used. That 10, (a) straight polarity (electrode negative) for the tungeten inert gas ahlelded (TIa) process, (b) reverse polarity (eleotrode poeltive) for the manul motal arc procese, and (c) reverse polarlty (eleotrode poeltive) for the notal lnort gae eblelded (uIa) prooess.

\section{HPAT TREATENT}

Preheat for weld shall be $70^{\circ}$. Maximun weld Interpaes temperature shall be $350 \%$. No post weld thermal treatment is required.

\section{XIII: QWATILICATION}

All weldine performed under this epeciflcation requiree both prooeduree and parformance qualifloation to be in accordance with the ABur Boller and Pressure Code (1950), 8ection IX, and to the requiremente of section B-14 and B-16 of "Intermediate Heat Bxchanger and stoan Generator 30m 8pootifiontiona".

\section{IMBP XCTION}

(1) The welded folnt ahall be $1006 x$-rayed where required by the Asar Boller and Pressure vessel Code. The procedures to be lollowed and the quality of welds shall weet the requirements of section VII 1 of the Agur Boller and Pressure Vessel Code and the add1tlomal provision that porasity shall not exceed that perintted

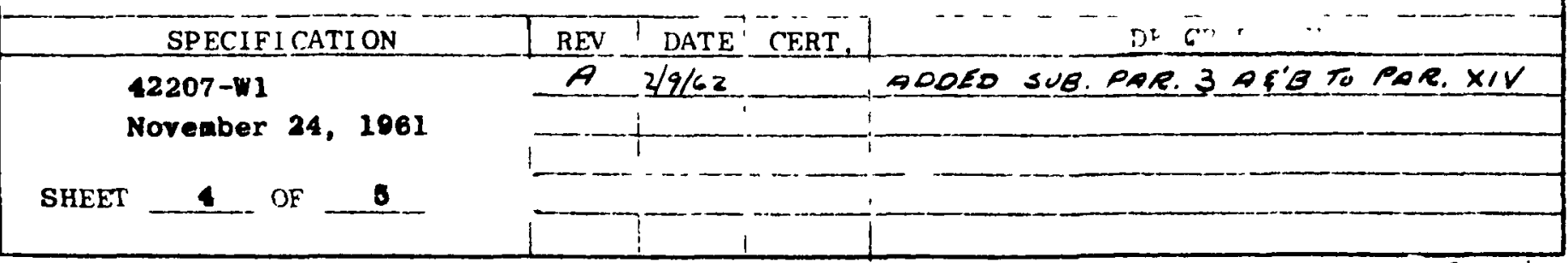




\section{ALCO ALCO PRODUCTS, incorporeted}

XIV. LNSPECTION (Cont.)

for $1 / 4^{n}$ plate or leas.

(2) All x-rays shall be subject to review by the contracting organisation.

(3) Interpretation of inapection sybola as used on trie attached weld sketchas atall be a followa:

(A) Process

"PT" - Penetrant test with 11qutd dye procen"

"Mr" - Radlograph test

"UT" - UItragonic tegt

"visual" - Vieund test

(B) Area of Inspeotion

"R" - Root layer

"g" - Back oblp or back cround aren

"F" - Final or completed weld. 

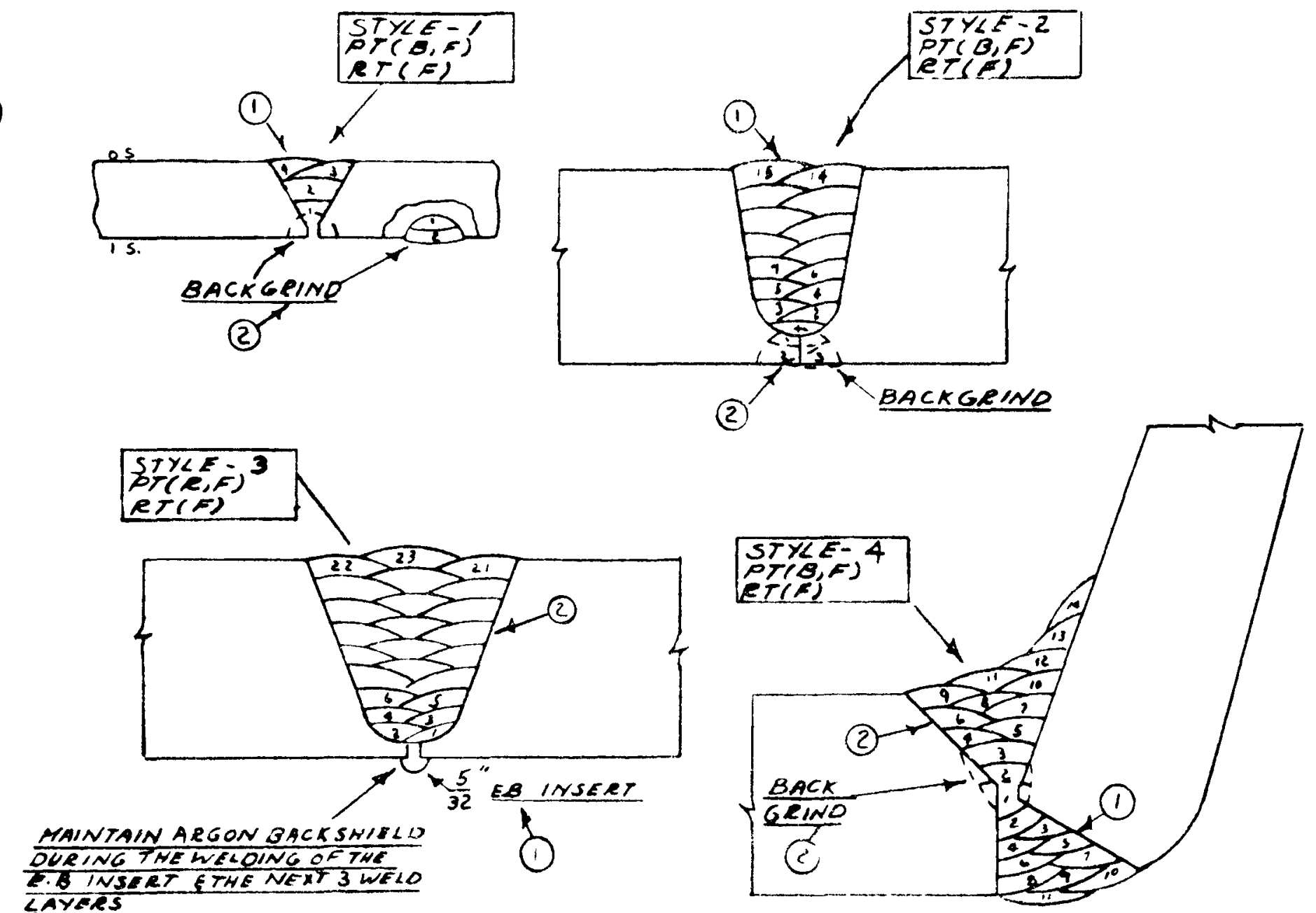
LAYERS

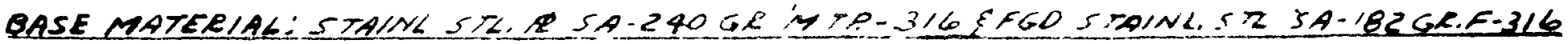

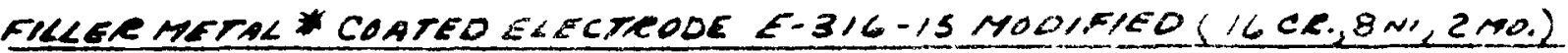

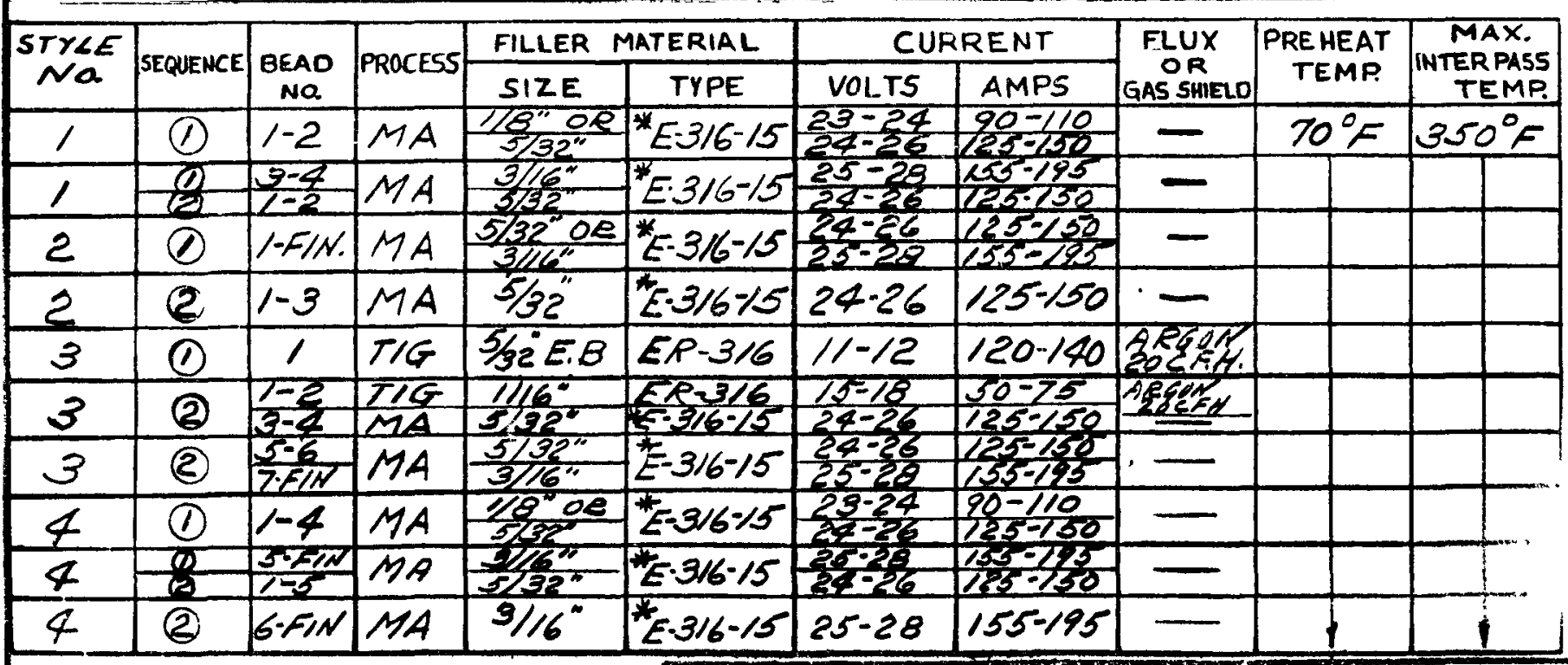

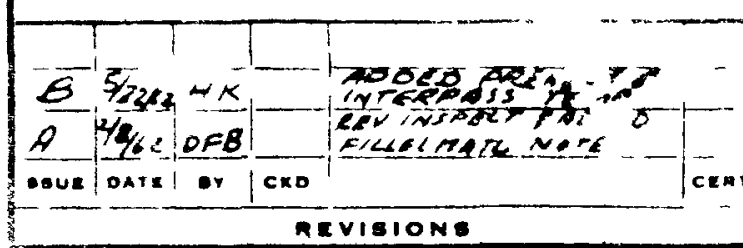

AEVISION
OUNK,F*, ALCG WRODLICTS, INC. pLANT No WR OING SPFCIEIG $9710 N$ FOE SHELLLONGE GIETH SAAMS ETL NOLZLESTOSHELL

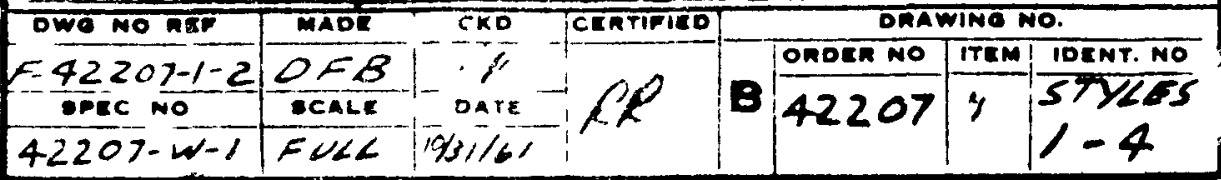



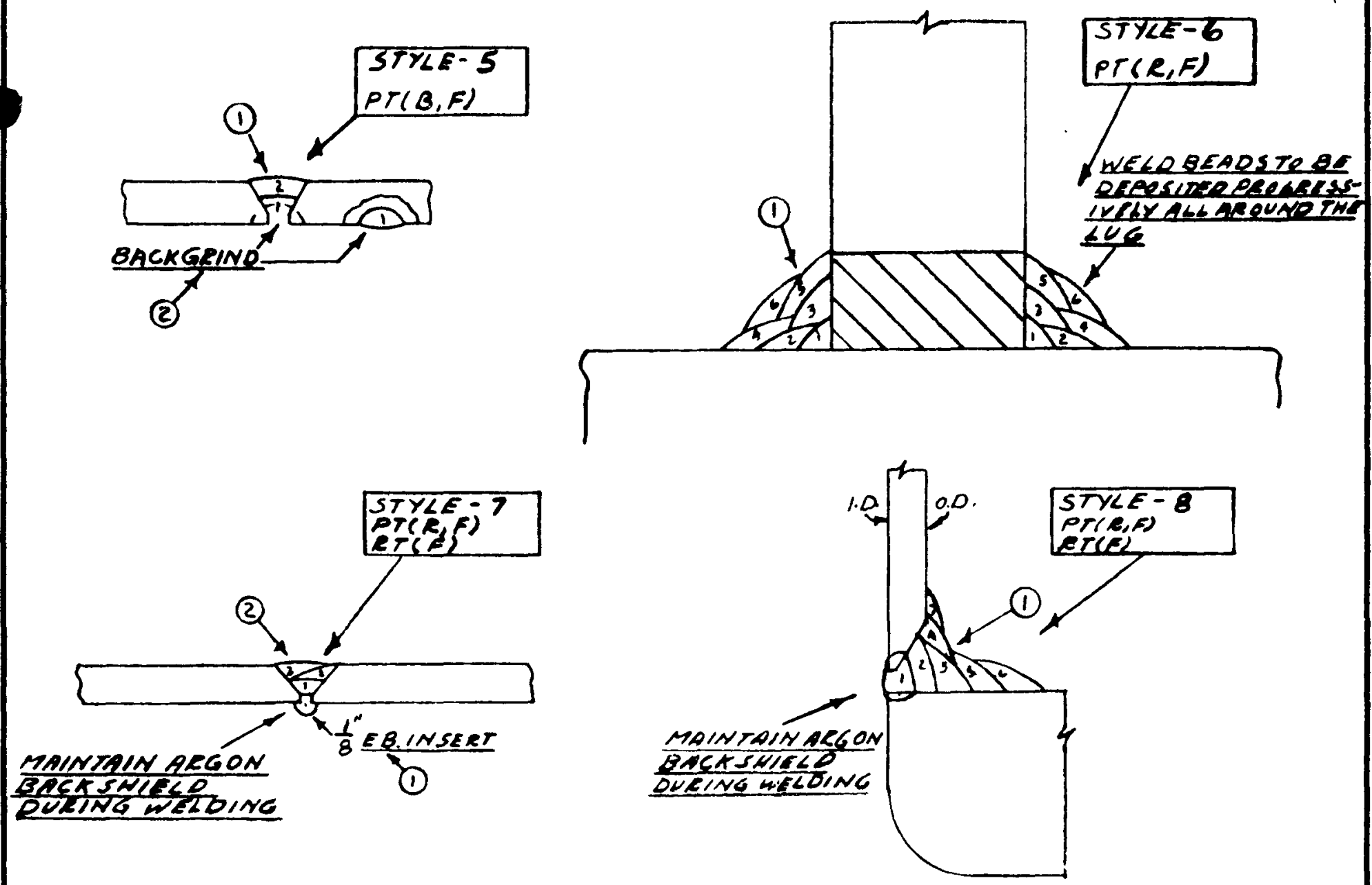
BASE MATERIAL: STAINL. 5TL. TR TP-304 FG0. 5TAINL STL SA-182 GE"F"TA 316

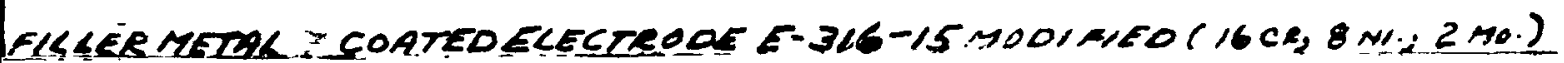

\begin{tabular}{|c|c|c|c|c|c|c|c|c|c|c|}
\hline \multirow{2}{*}{$\begin{array}{c}\text { STY<E } \\
N a\end{array}$} & \multirow{2}{*}{ SEQUENCE } & \multirow{2}{*}{$\begin{array}{c}\text { BEAD } \\
\text { NO. }\end{array}$} & \multirow{2}{*}{ PROCESS } & \multicolumn{2}{|c|}{ FILLER MATERIAL } & \multicolumn{2}{|c|}{ CURRENT } & \multirow{2}{*}{$\begin{array}{l}\text { FLUX } \\
\text { OR } \\
\text { GAS SHELLO }\end{array}$} & \multirow{2}{*}{$\begin{array}{c}\text { PRE HEAT } \\
\text { TEMP. }\end{array}$} & \multirow{2}{*}{$\begin{array}{l}\text { MAX. } \\
\text { INTERPASS } \\
\text { TEMP. }\end{array}$} \\
\hline & & & & \multirow{2}{*}{$\frac{\text { SIZE }}{17 e^{\prime O A}}$} & \multirow{2}{*}{$\frac{\text { TYPE }}{E-308-15}$} & \multirow{2}{*}{$\begin{array}{c}\text { VOLTS } \\
23=24 \\
24-26\end{array}$} & \multirow{2}{*}{$\begin{array}{l}\text { AMPS } \\
90-110 \\
\frac{90}{2} / 150\end{array}$} & & & \\
\hline 5 & (D) & $1-F / N$ & $M A$ & & & & & - & $70^{\circ} \mathrm{F}$ & $350^{\circ} \mathrm{F}$ \\
\hline 5 & (2) & HFIN & $M A$ & $2 / 32$ & $E \cdot 308-15$ & $24-26$ & 125-150 & $\longrightarrow$ & & \\
\hline 6 & (1) & $\frac{1}{2-F / N}$ & $M A$ & & $E-308 \cdot 15$ & $34-36$ & $\frac{725: 135}{155 \cdot 195}$ & $=$ & & \\
\hline 7 & $\frac{8}{5}$ & -EIN & $T / G$ & $\frac{186}{1126}$ & $E x-316$ & $\begin{array}{l}9-11 \\
2-11\end{array}$ & $\frac{65.75}{60.70}$ & $\begin{array}{l}\text { ARGON } \\
15 \text { CIFH }\end{array}$ & & \\
\hline 8 & (1) & $1-2$ & TIG & $116^{\prime \prime}$ & $E P-316$ & $9-11$ & $50-70$ & $\begin{array}{l}\text { ARGON } \\
\text { OEGEGM }\end{array}$ & & \\
\hline 8 & (1) & $3: F / N$ & $M A$ & $362^{\prime \prime}$ & $2 \cdot 316 \times 5$ & 24.26 & $125-150$ & - & & \\
\hline & & & & & & & & , & & \\
\hline
\end{tabular}

ALCO PRODUCTS, INC. Jant No 3

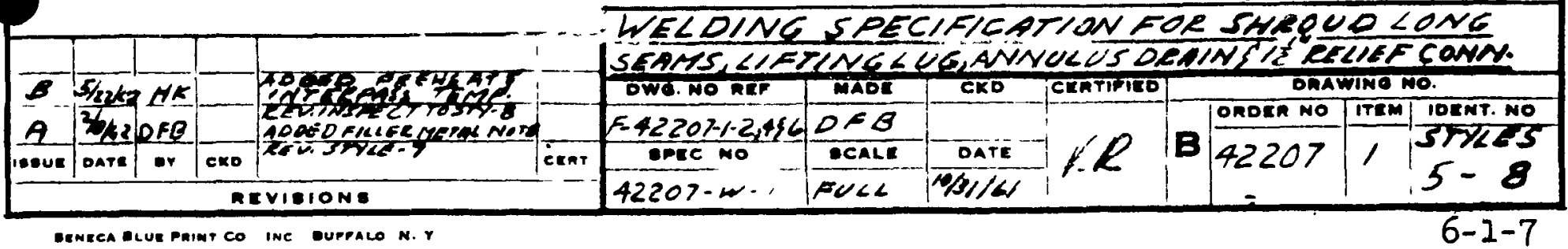




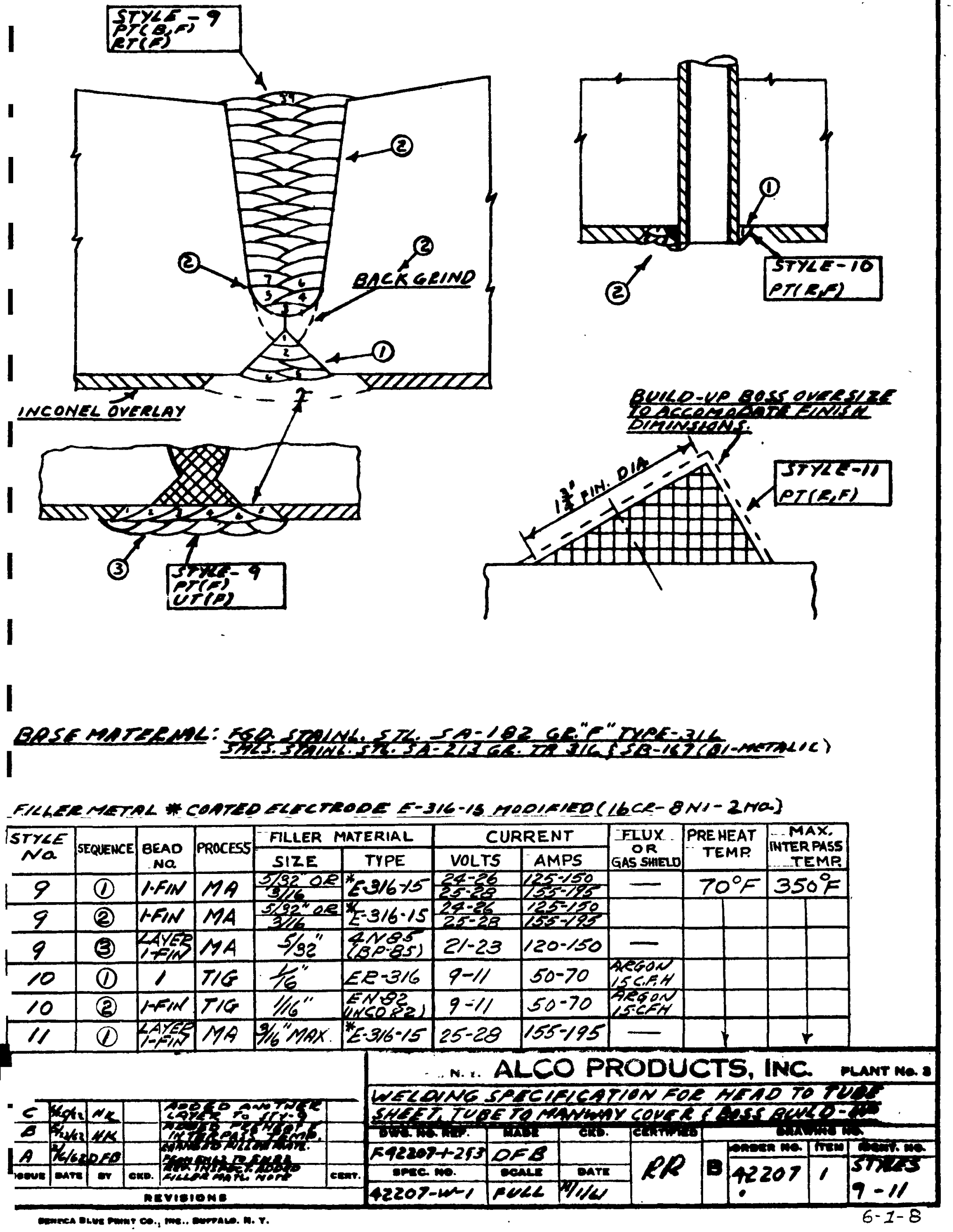



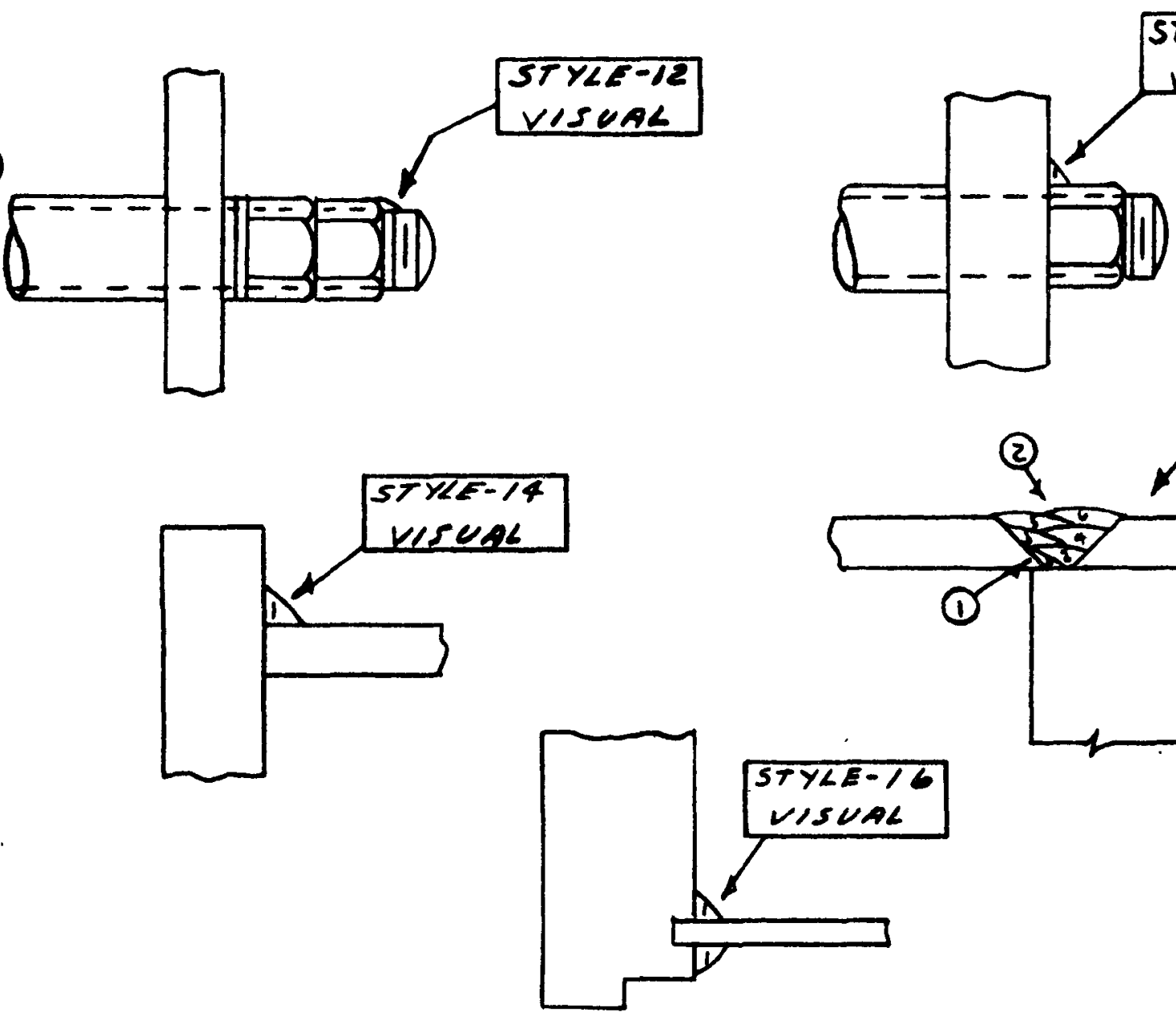

(2)

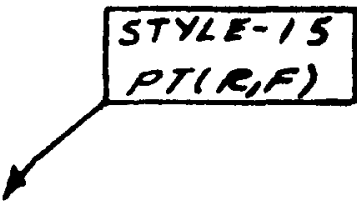

(1)

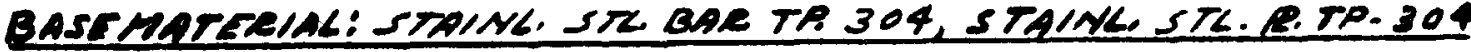

\begin{tabular}{|c|c|c|c|c|c|c|c|c|c|c|}
\hline \multirow{2}{*}{$\begin{array}{c}S T Y<E \\
N a\end{array}$} & \multirow{2}{*}{ SEQUENCE } & \multirow{2}{*}{$\begin{array}{c}\text { BEAD } \\
\text { Na }\end{array}$} & \multirow{2}{*}{ PROCESS } & \multicolumn{2}{|c|}{ FILLER MATERIAL } & \multicolumn{2}{|c|}{ CURRENT } & \multirow{2}{*}{$\begin{array}{l}\text { EELUX } \\
-O R \\
\text { GAS SHIELO }\end{array}$} & \multirow{2}{*}{$\begin{array}{l}\text { PRE HEAT } \\
\text { TEMP. }\end{array}$} & \multirow{2}{*}{$\begin{array}{l}\text { MAX. } \\
\text { INTERPASS } \\
\text { TEMPP. }\end{array}$} \\
\hline & & & & SIZE & TYPE & VOLTS & AMPS & & & \\
\hline $12-13$ & (D) & 1 & TIG & $1 / 16^{10}$ & $E R-308$ & $9-11$ & $60-70$ & 3EEED & $70^{\circ}$ & $350^{\circ} \%$ \\
\hline 14 & (1) & 1 & $M A$ & $1 / 80$ & $E: 308-15$ & $23-24$ & $90 \cdot 110$ & 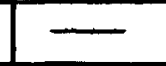 & & \\
\hline 15 & $(1)$ & 1 & $T / G$ & $146^{\circ 0}$ & $E R \cdot 308$ & $1 /-13$ & $90-120$ & AEGOA & & \\
\hline 15 & (2) & 24 & $M A$ & & $F-308.15$ & $\frac{23-24}{24-26}$ & $\frac{90-110}{25=150}$ & תוב & & \\
\hline 15 & (2) & 5 5IN & $M A$ & & $E .308 \%$ & $\frac{24-26}{25-28}$ & $\frac{25-15}{155-192}$ & $=$ & & \\
\hline 16 & (1) & 1 & TIG & $\frac{11004}{3 x 32}$ & $E R-308$ & $11 \cdot 13$ & $90 \cdot 120$ & $\begin{array}{l}\text { BEGON } \\
\text { BSERHA }\end{array}$ & & \\
\hline & & & & & & & & & & \\
\hline & & & & & & & & & & \\
\hline
\end{tabular}

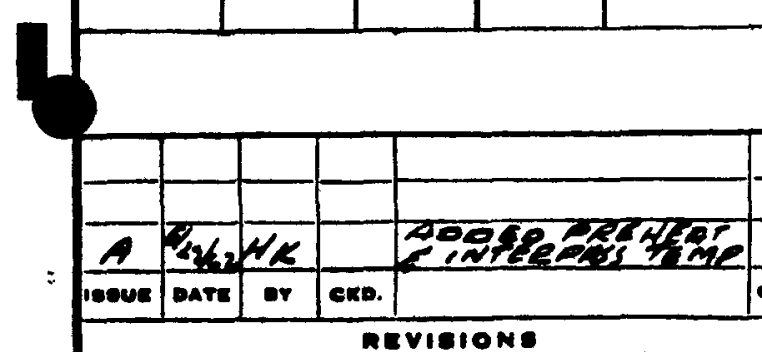

DUY:K:RK, N.Y ALCU PRODUCTS, INC. PLANT Mo. a WELDING SPECIFICATION EOR BAFFLE ASSEMRLY SHEOUO F SHIELDING WELOS

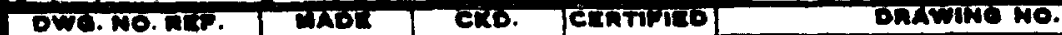

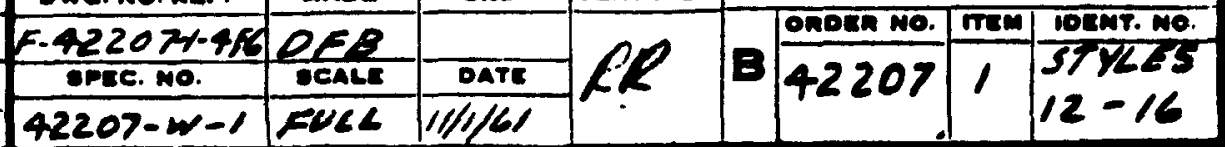


I
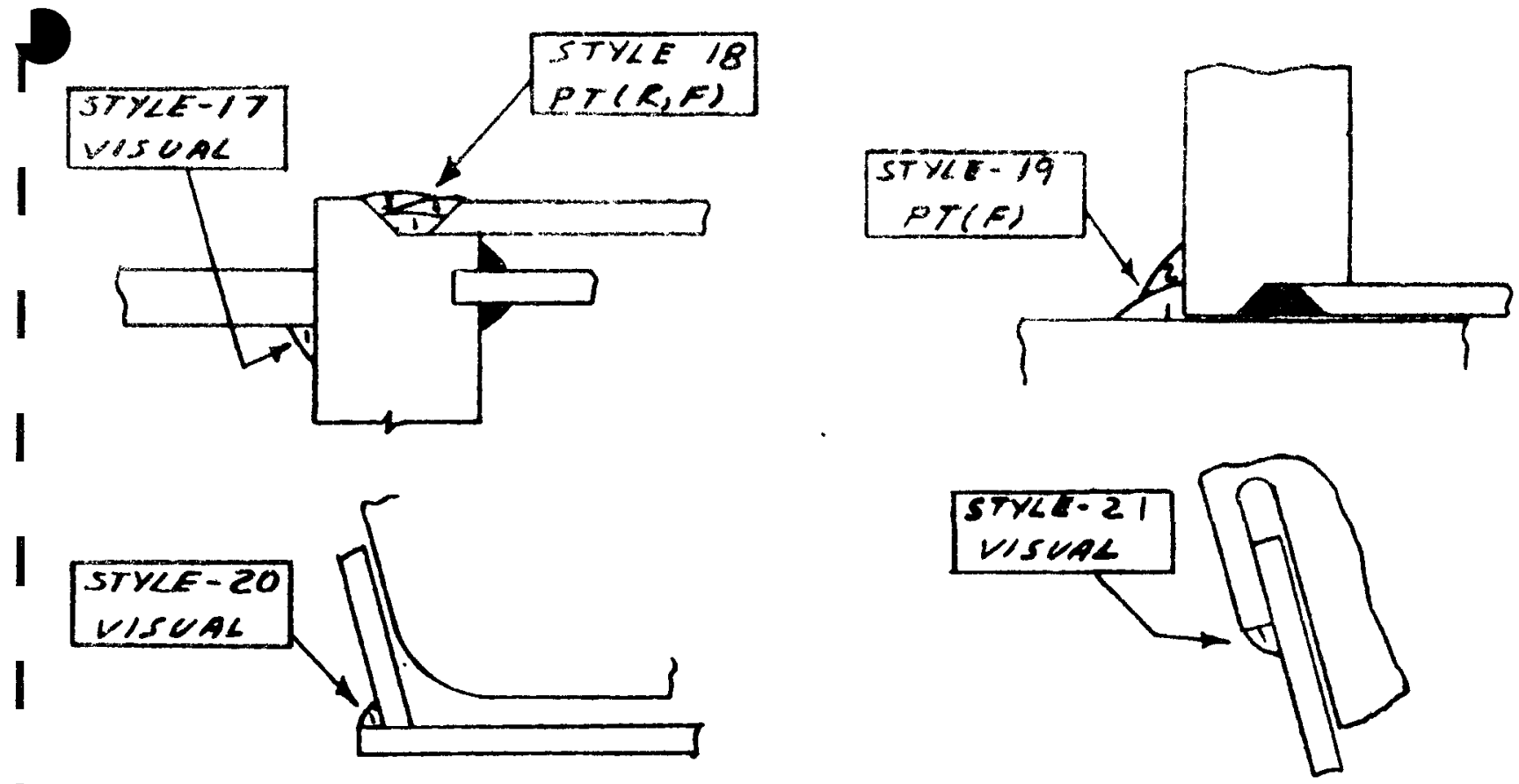

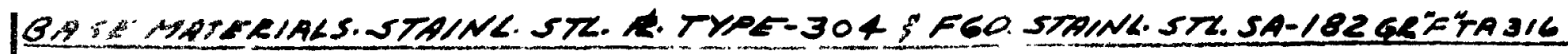

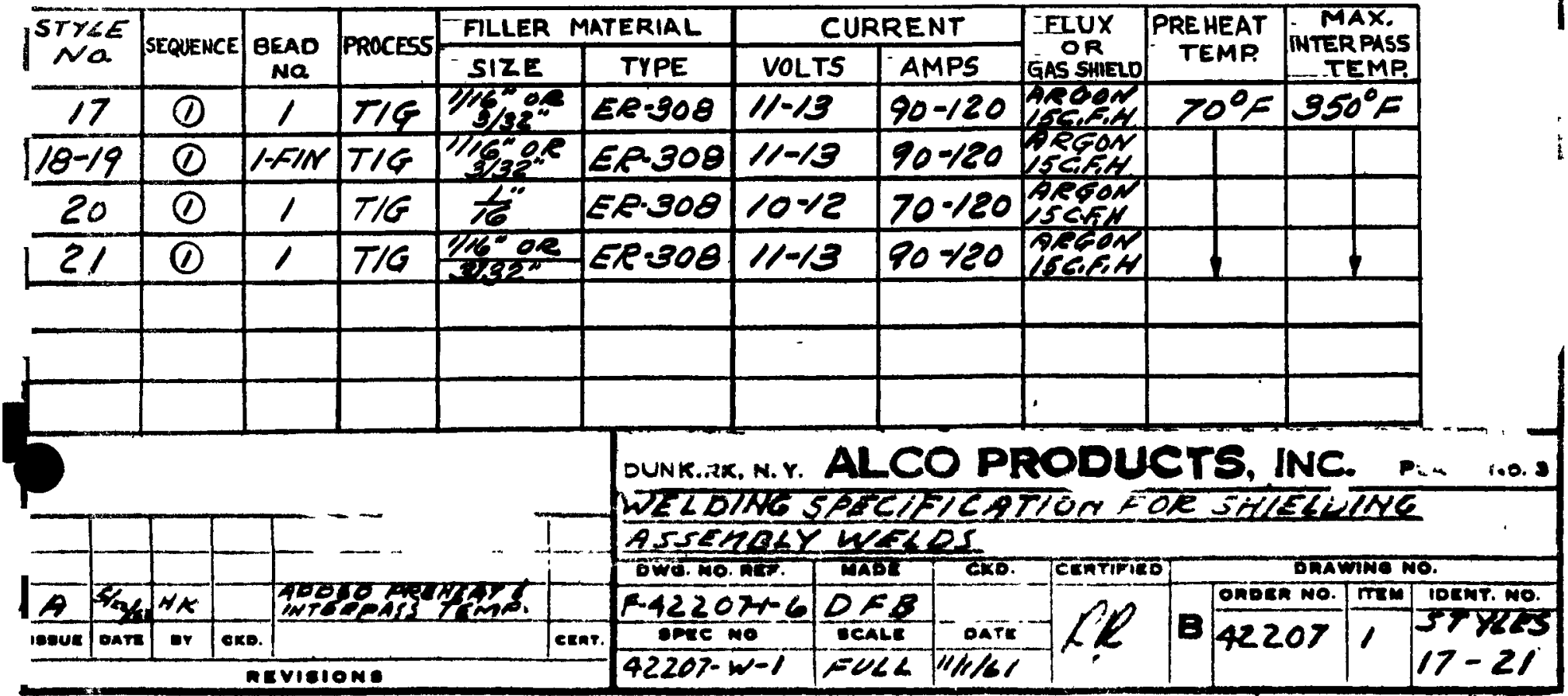



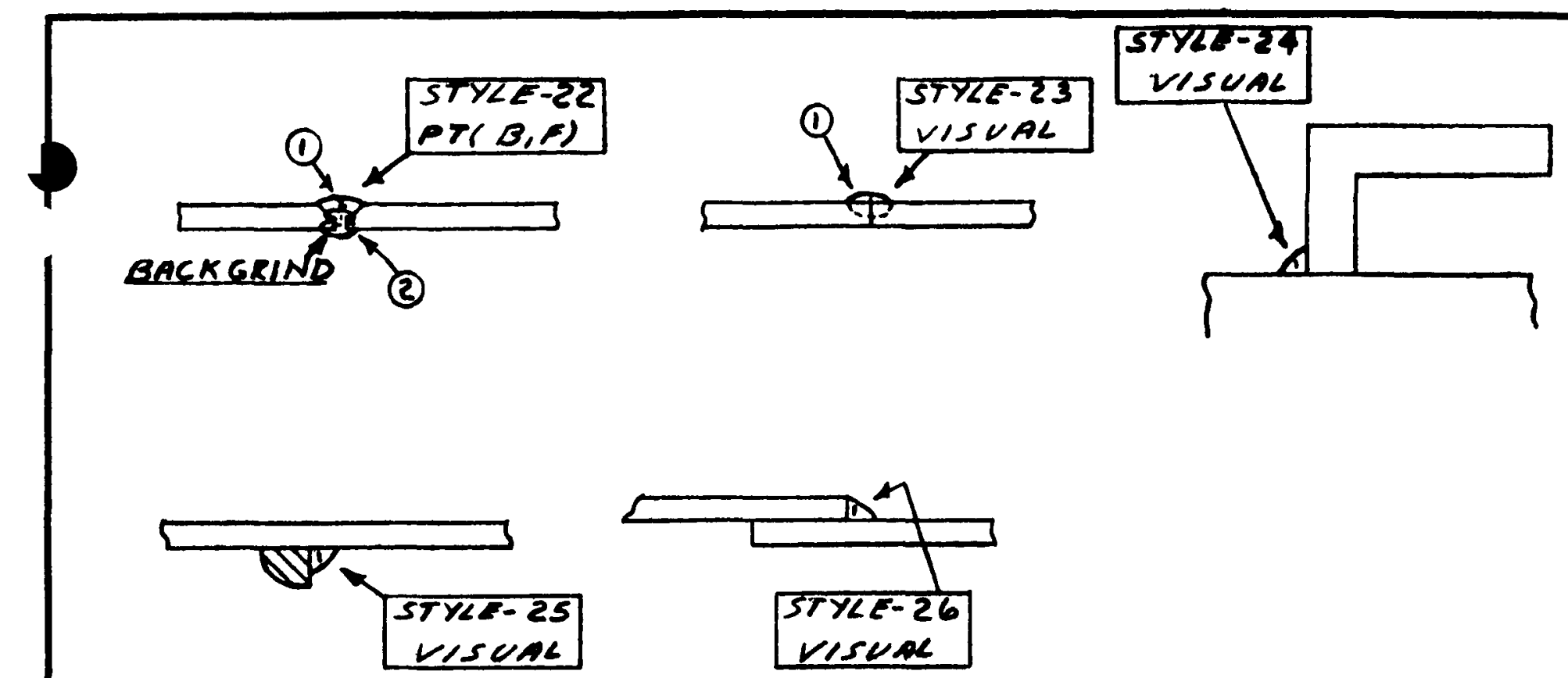

SQSEMOTL. STANNL. STL. TP- 304

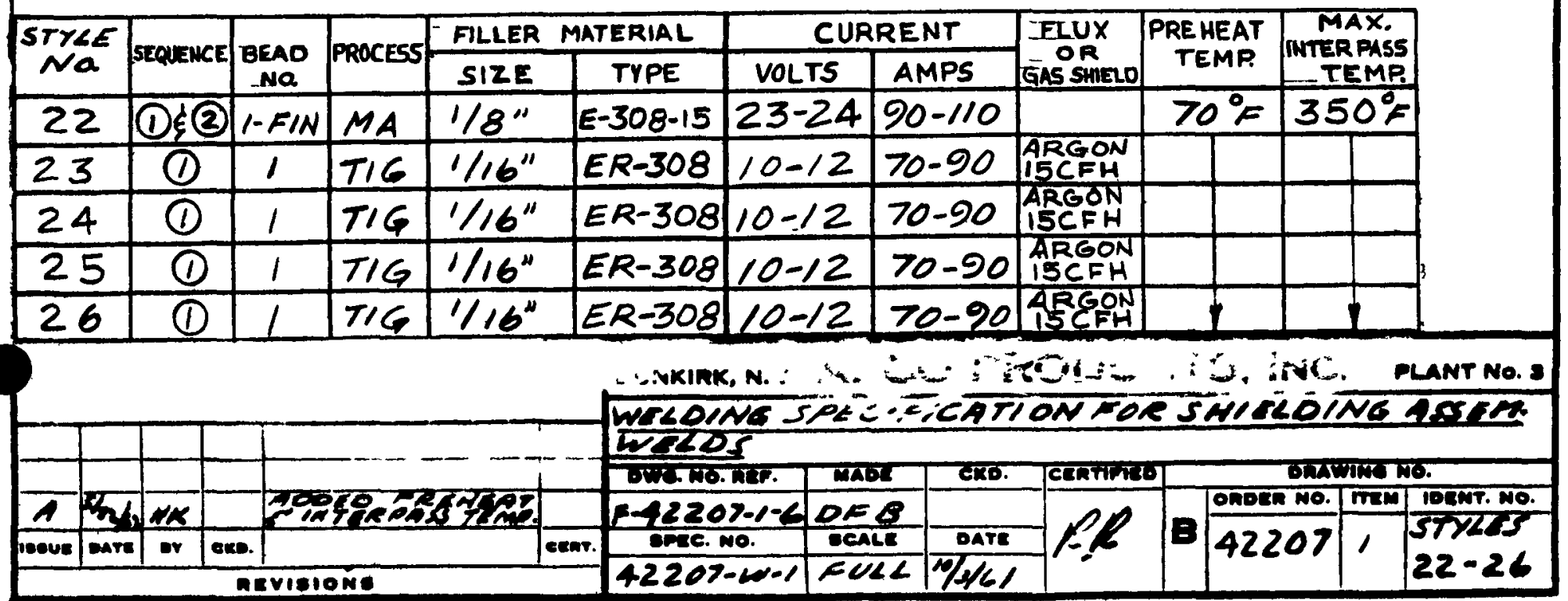




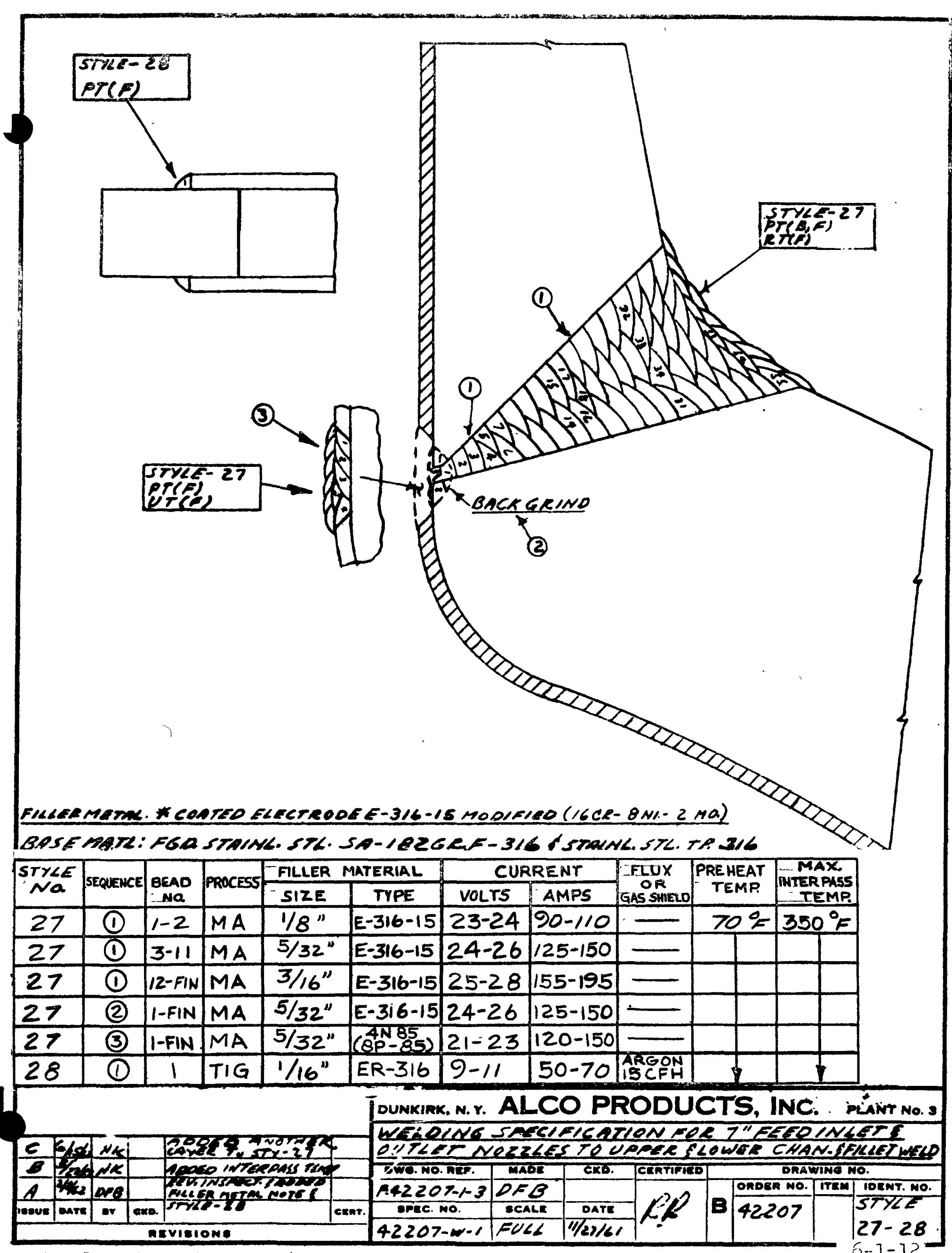




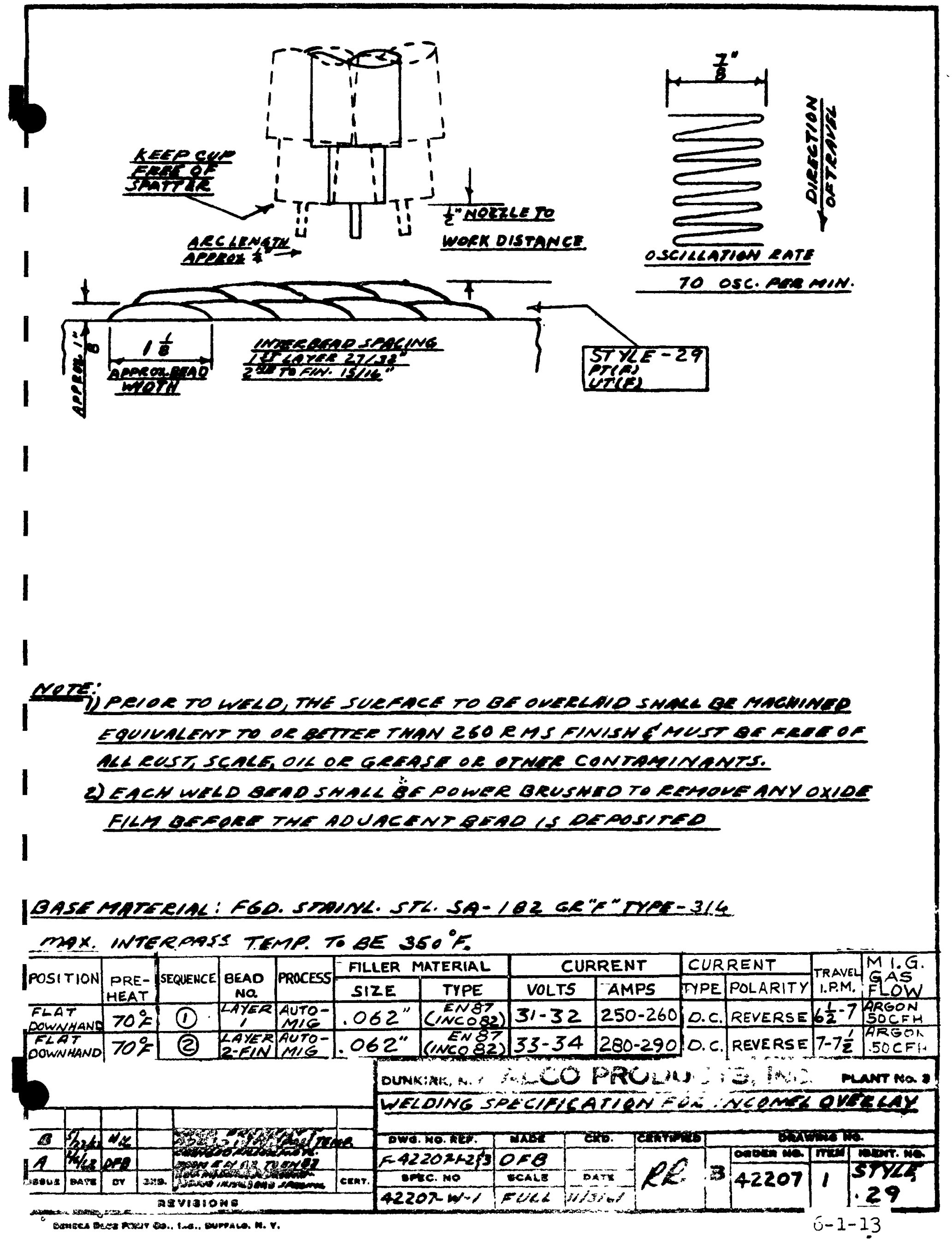




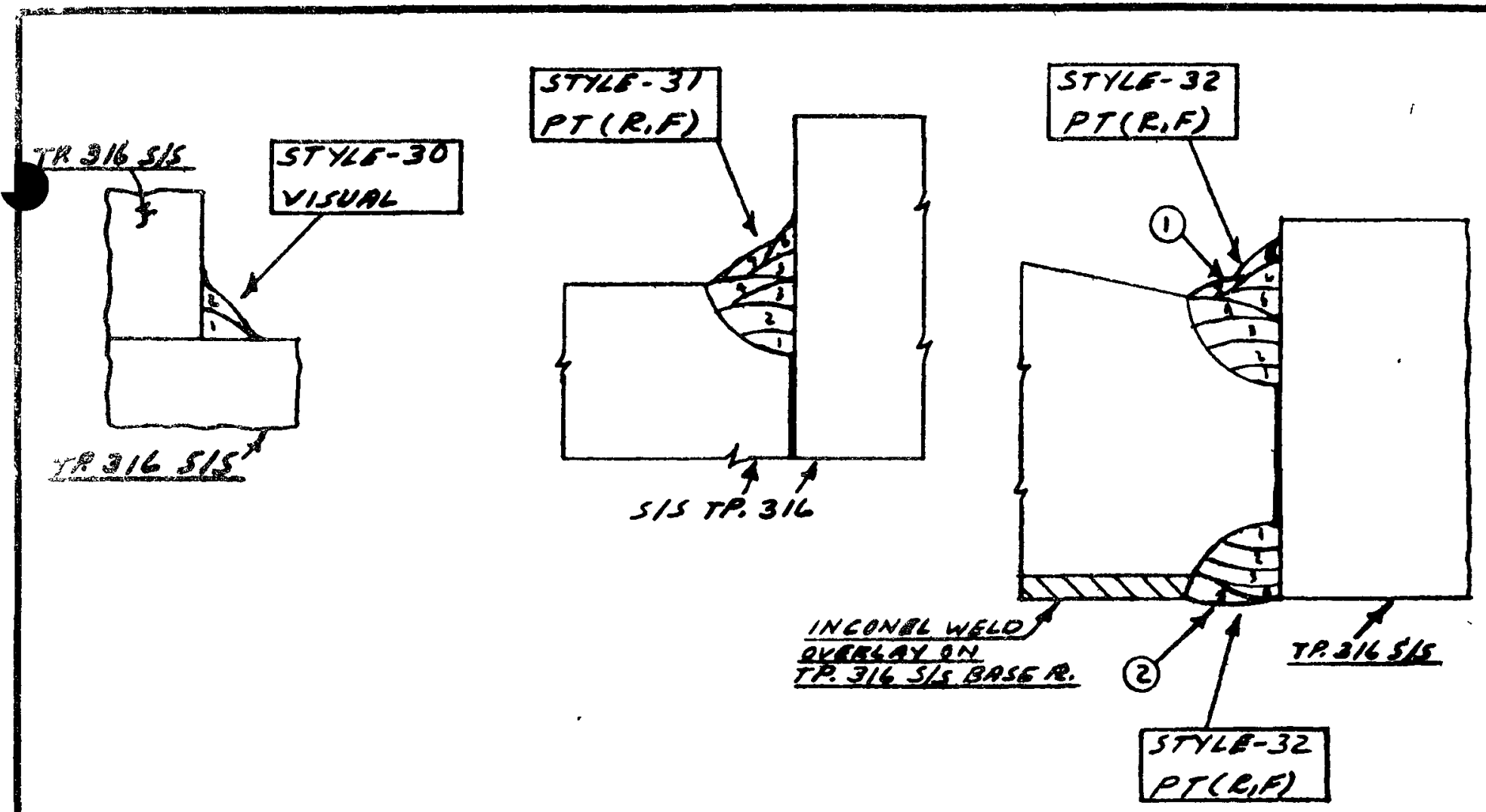

6.

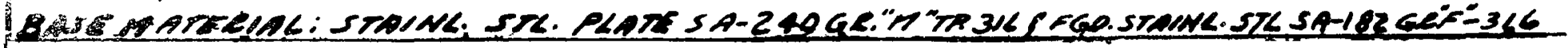

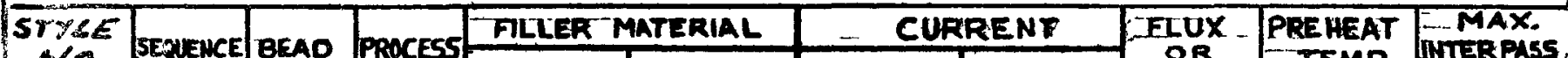

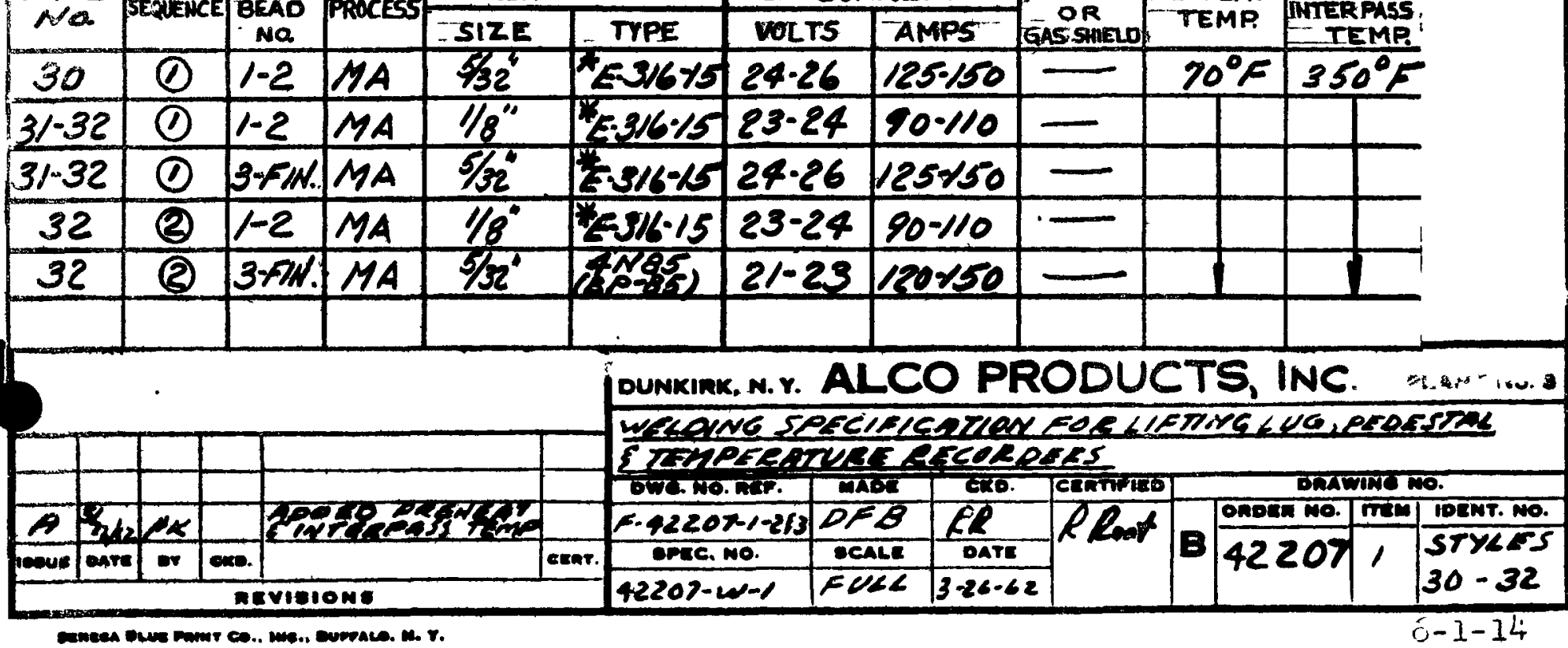



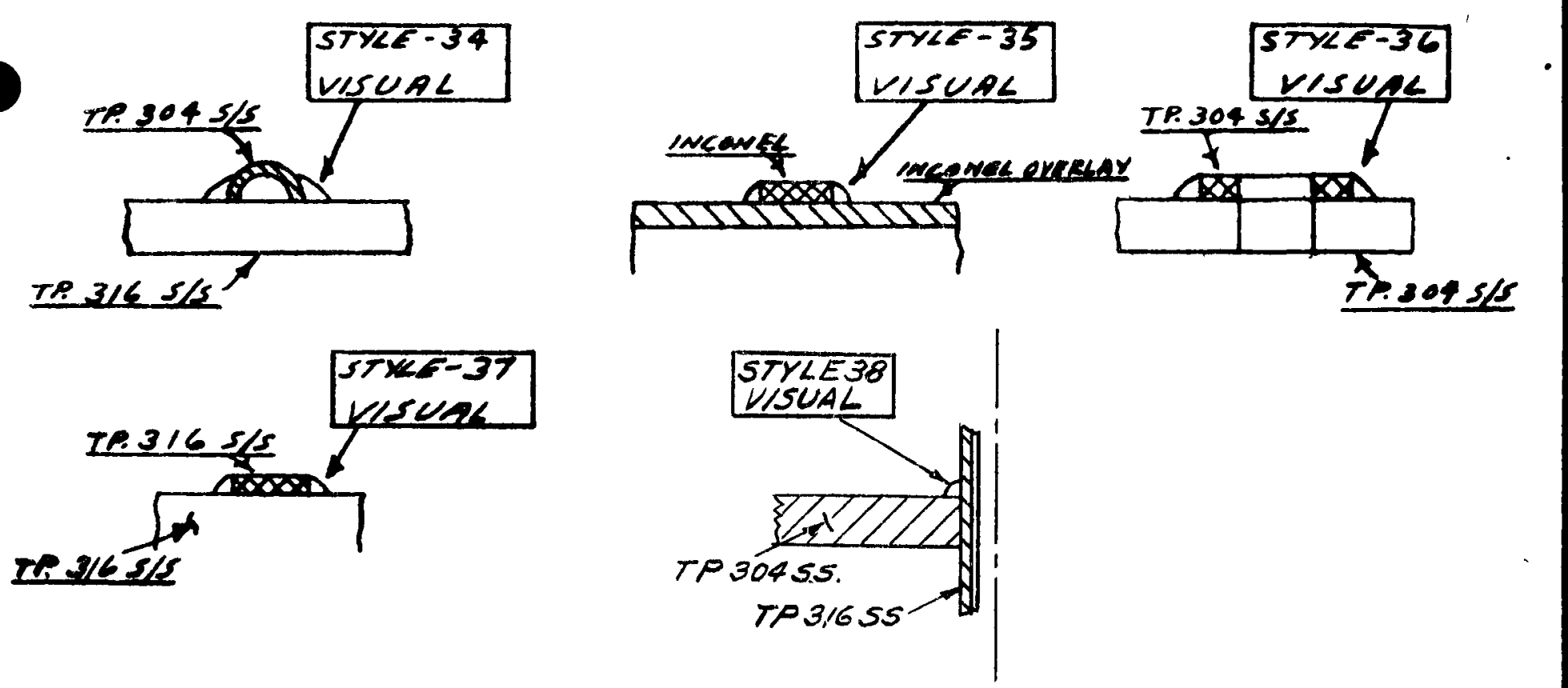

BASE MATL. STAINL. STL, T.P 304, B\% 168 (INCONEL), STAINL. STL. T.P. 316

\begin{tabular}{|c|c|c|c|c|c|c|c|c|c|c|}
\hline \multirow{2}{*}{$\begin{array}{c}\text { STYLE } \\
\text { NO. }\end{array}$} & \multirow[b]{2}{*}{ SEQ. } & \multirow{2}{*}{$\begin{array}{l}\text { BEAD } \\
\text { NO. }\end{array}$} & \multirow{2}{*}{ PPocess } & \multicolumn{2}{|c|}{ FILLER MATERIAL } & \multicolumn{2}{|c|}{ CURRENT } & \multirow{2}{*}{ FLuX } & \multirow{2}{*}{$\begin{array}{l}\text { PREHEAT } \\
\text { TEMP. }\end{array}$} & \multirow{2}{*}{ 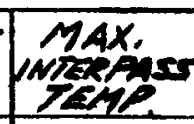 } \\
\hline & & & & $S / Z E$ & TYPE & VOLTS & \begin{tabular}{|l} 
AMPS \\
\end{tabular} & & & \\
\hline 34 & (1) & 1 & $T / G$ & $11 "$ & $E R \cdot 308$ & 9.11 & 50.70 & RESON & $70^{\circ} \mathrm{F}$ & $350^{\circ} \mathrm{F}$ \\
\hline 35 & (1) & 1 & $T / G$ & $1 / 16$ & 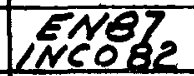 & $9-11$ & $50-70$ & 85904 & & \\
\hline $36-37$ & (1) & 1 & $T / G$ & $1 / 16$ & ER.308 & $9 \cdot 11$ & $50-70$ & & & \\
\hline 38 & (1) & 1 & $T / G$ & $1 / 16^{\circ}$ & ER:308 & $9-11$ & $50-70$ & ARGON & & \\
\hline
\end{tabular}

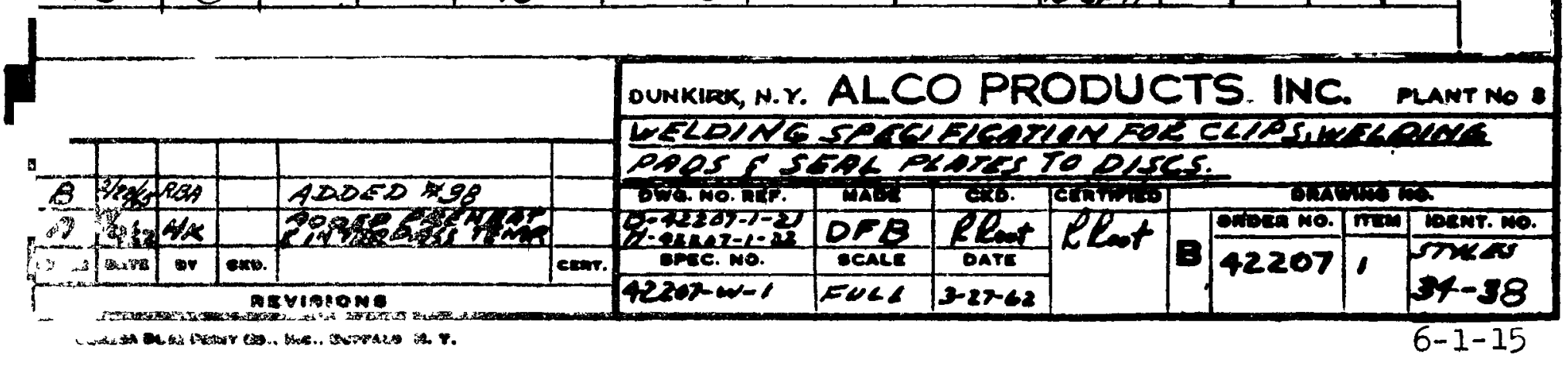




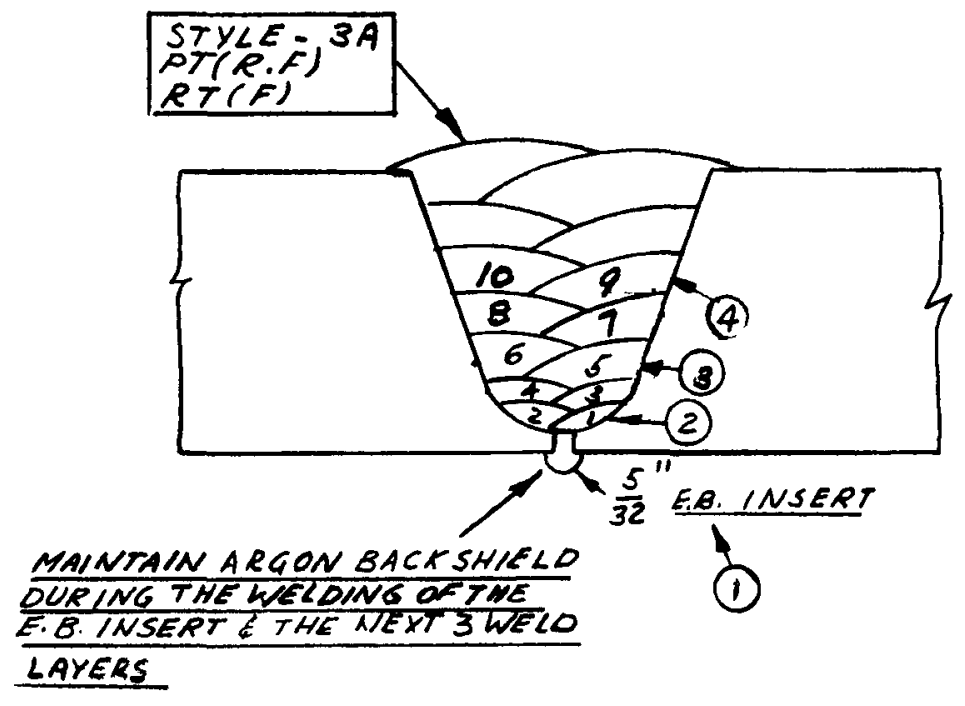

BASE MATL: STAINL. STL SA-240 GR. M" TD. 316 FGO, STAINL. STL. SA-182 GR. F-316

FILLER METAL

SEQUENCE 3 - COATEO ELECTRODE E-316-15 MODIFIEO (16 CR., 8N1, 2 MO.) SEQUENCE 4-SUB-ARC WIRE-CONFORMANCE TO ASTM-A-371-53T FLUX TYPE ARCOSITE S-4 WITH 3TO5\% DELTA FERRITE IN WELO NUGGET BASEO ON CHEMICAL EQUIVALENTS APRLIED TO THE SCHAEFFLER DIAGRAM.

\begin{tabular}{|c|c|c|c|c|c|c|c|c|c|c|c|}
\hline \multirow{2}{*}{$\begin{array}{c}S T Y L E \\
\text { NO }\end{array}$} & \multirow{2}{*}{ SEQUEACE } & \multirow{2}{*}{$\begin{array}{c}\text { BEPD } \\
\text { NO. }\end{array}$} & \multirow{2}{*}{ Process } & \multicolumn{2}{|c|}{ FILLEP MATERIAL } & \multicolumn{2}{|c|}{ CUPAENT } & \multirow{2}{*}{ 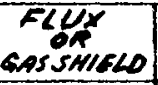 } & \multirow{2}{*}{$\begin{array}{l}\text { PRENEAT } \\
\text { TEMP. }\end{array}$} & \multirow{2}{*}{$\begin{array}{l}\text { Max. INTER- } \\
\text { PASS TEMP }\end{array}$} & \multirow{2}{*}{$\begin{array}{l}\text { TRAV' } \\
\text { SAECD }\end{array}$} \\
\hline & & & & $S / 2 E$ & TYPE & VOLTS & AMPS & & & & \\
\hline $3 A$ & (1) & 1 & 716 & $5 / 32 E B$ & ER $3 / 6$ & $11-12$ & $120-140$ & $\begin{array}{l}\text { APGON } \\
20 C F H\end{array}$ & $70^{\circ} \mathrm{F}$ & $3500 \mathrm{~F}$ & - \\
\hline $3 A$ & (2) & $1-4$ & $7 / G$ & $1 / 6$ & $E R 3 / 6$ & $15-18$ & 50.75 & $\begin{array}{l}\text { ARGON } \\
\text { EOCFN }\end{array}$ & $70^{\circ} \mathrm{F}$ & $350^{\circ} \mathrm{F}$ & 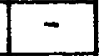 \\
\hline $3 A$ & (3) & $5-8$ & $M A$ & $5 / 32$ & $E 3 / 6-15$ & $24-26$ & $125-150$ & - & $70 \% \mathrm{~F}$ & $350 \%$ & - \\
\hline $3 A$ & (4) & P-FIN & $\begin{array}{l}\text { SUE. } \\
\text { ARC }\end{array}$ & $5 / 32$ & $E R-316$ & $30-32$ & $350-450$ & $\begin{array}{c}\text { AAtes } \\
s-4\end{array}$ & $70^{\circ} \mathrm{F}$ & $350^{\circ} \mathrm{F}$ & 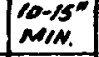 \\
\hline
\end{tabular}

$\phi$ NOTE: Excess flux shall be removed from adjacent weld areas and reused once during the weld process.

Any flux that has been contaminated by coming in contact with foreign surfaces shall not be picked up into the vacuum.

\begin{tabular}{|c|c|c|c|}
\hline \multicolumn{4}{|c|}{ DRAWING NO. } \\
\hline & ORDER NO & ITEM & IDENT.NO. \\
\hline B & 42207 & I & $\begin{array}{l}\text { STYLE } 3 A \\
\text { (ALTERNATE } \\
\text { STYLE } 3 \text { ) }\end{array}$ \\
\hline
\end{tabular}




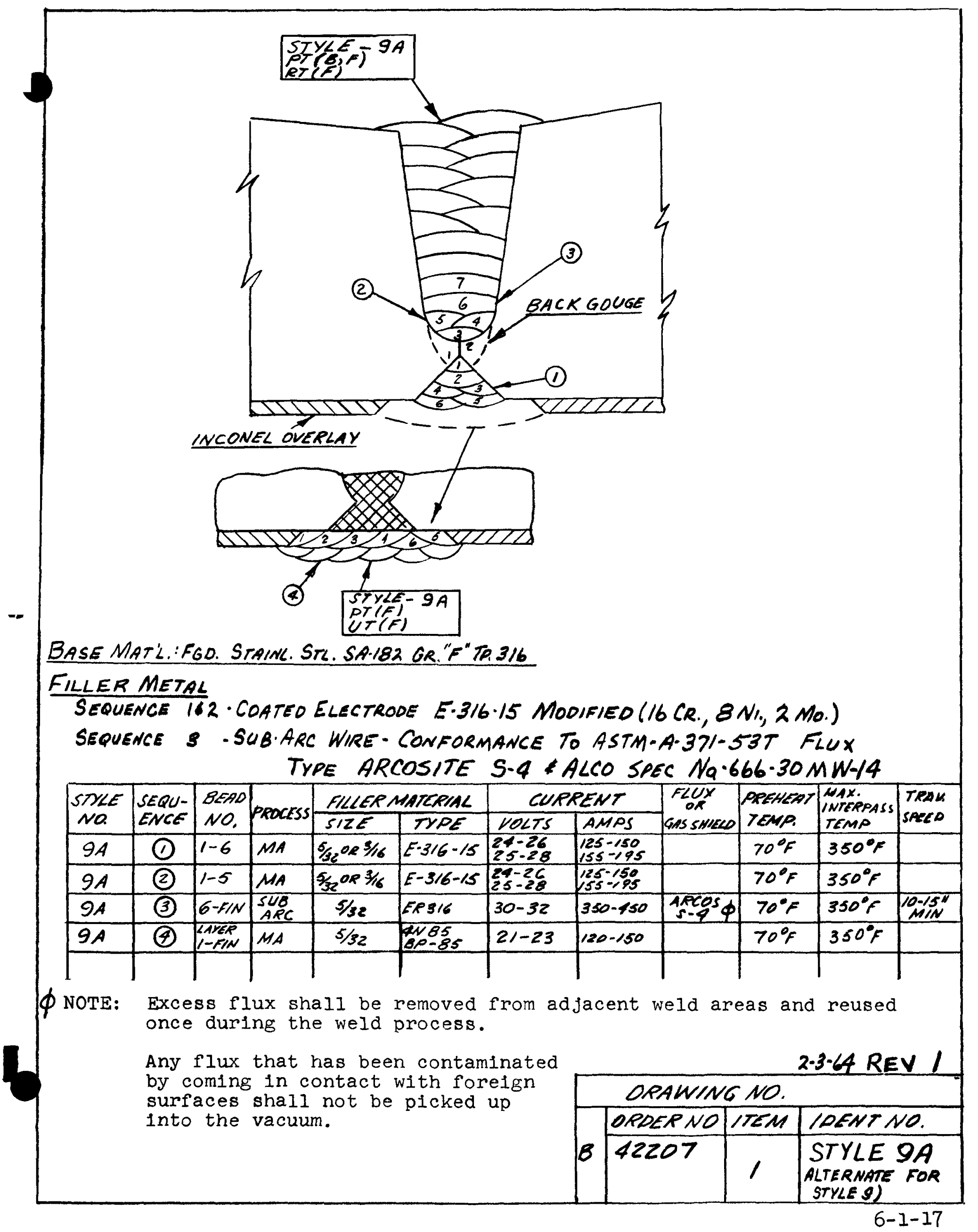




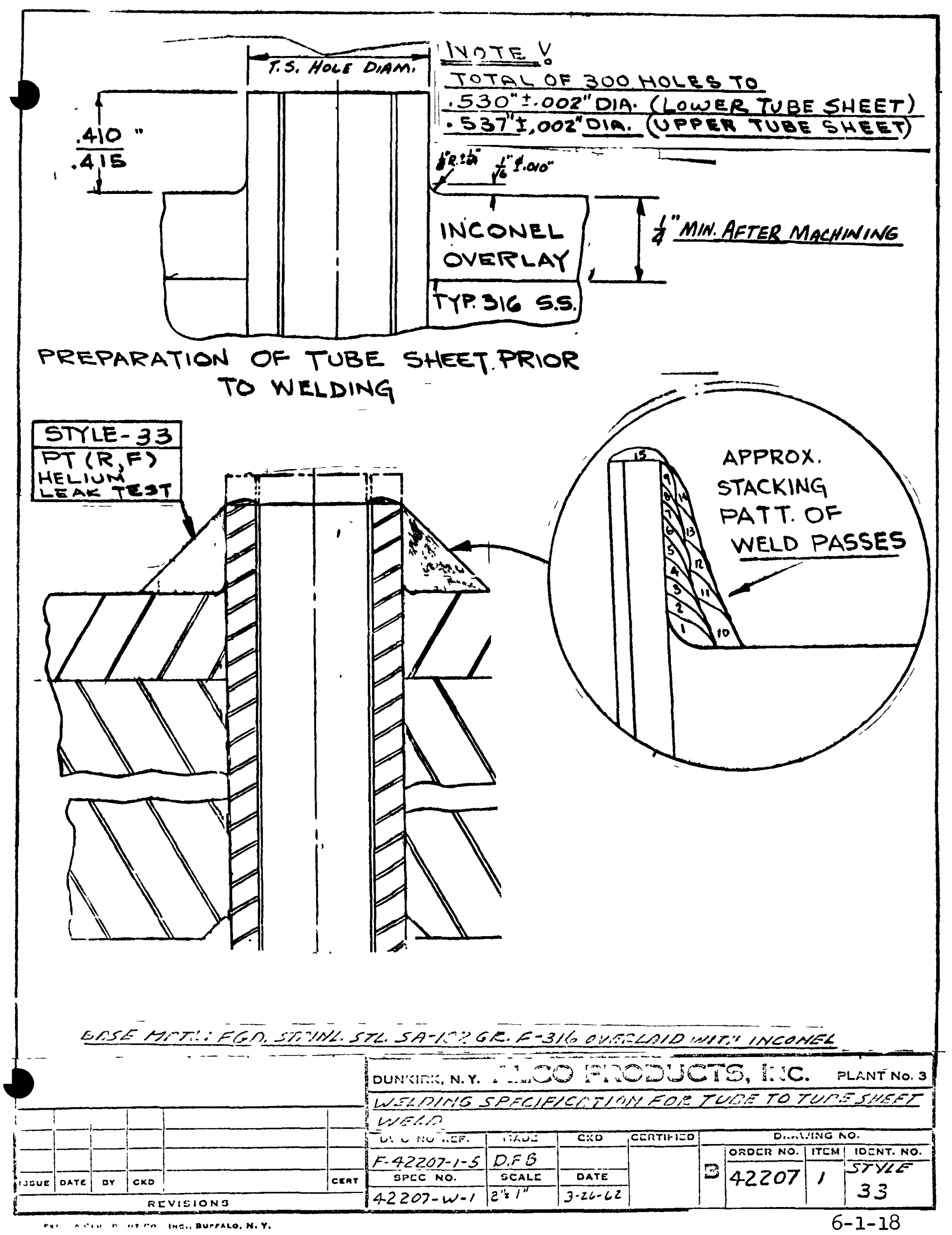




\section{WELDTNG MACHINE CONTKOL PANET}

$\begin{array}{ll}\text { Main Rheostat } & \text { - Maximum } \\ \text { Remote Output Control } & \text { - Remote Position } \\ \text { Soft Start } & \text { - Inoperatire } \\ \text { Process } & - \text { Inert Gas Arc Welding } \\ \text { High Frequency } & - \text { Automatic } \\ \text { High Frequency Control } & \text { - Phase Shift - Maximm } \\ \text { Range Switch } & \text { Intensity - Maximum } \\ \text { Selector Switch } & - \text { Medium Range } \\ \end{array}$

ELECTRODE FILTER WIRE SHTELDING GAS

Tungsten Electrode - 1/8" dia., 2\% Thoriated Tungsten with tip ground to a point on an angle of 45 degrees, and with a $.030^{\prime \prime}$ flat along its side opposite the tip.

Filler Wire

- .030" dia., Inconel 82T on $21 \mathrm{~b}$. capacity spools.

Shielding Gas - Welding Grade Argon, 40 cfh flow 


\section{TNSTRUCTIONS FOI ALIGNMENT AND SET-UP OF}

TUEE WEIDING GUN PRIOR TO WEIDING

1. Alignment of Tube Welding Gun with Mounting Post

The welding gun must be aligned parallel with the mounting post so that as the mounting post is adjusted perpendicular to the tubesheet to be welded, the welding gun will remain in a proper relative position. Parallelism of the welding gun and mounting post must be maintatned during welding. C1rcular levels are attached to the welding gun and mounting post to obtain correct alignment.

a. Adjust the mounting post to a vertical position with the mounting screws on the base using the circular level on the mounting post as a guide.

b. Adjust the welding gun to a vertical position with the fourway mounting bracket, using the circular level on the top of the gun as a guide.

2. Alignment of the Welding Gun with the Tubesheet

Align the welding gun with the tubesheet to be welded by means of the adjusting screws on the base of the mounting post. Position the locator down until it bottoms against the stop and move the gun over the tubesheet surface to check alignment, using the tip of the locator as guide. The welding gun should be allgned with the tubosheet to be welded within .005 inches. 
3. Electrode Projection

Projection of the electrode from the shielding gas nozzle must be set at .200 inch with a gauge, prior to adjusting arc length. The electrode projection must be checked frequently and maintained at the proper length during the welding operation.

4. Arc Length Adjustment

a. Place the locator Into a tube to be welded.

b. Move the gun down until the tungsten electrode just touches the tubesheet.

c. Set the dial indicator to zero.

d. Move the gun up until the desired are length is obtained.

e. Set the stop on the vertical travel.

NOTE: Extreme care should be exercised in performing step "b". If too much pressure is exerted as the electrode touches the tubesheet, the electrode can move within the collet - or the positioning arm can be moved upward and an incorrect adjustment will be obtained. After setting the dial indicator to the zero position, repeat step "b" without observing the dial indicator while the adjustment is being made, until at least three consecutive adjustments produce the same results. 


\section{WELDING CONDITIONS}

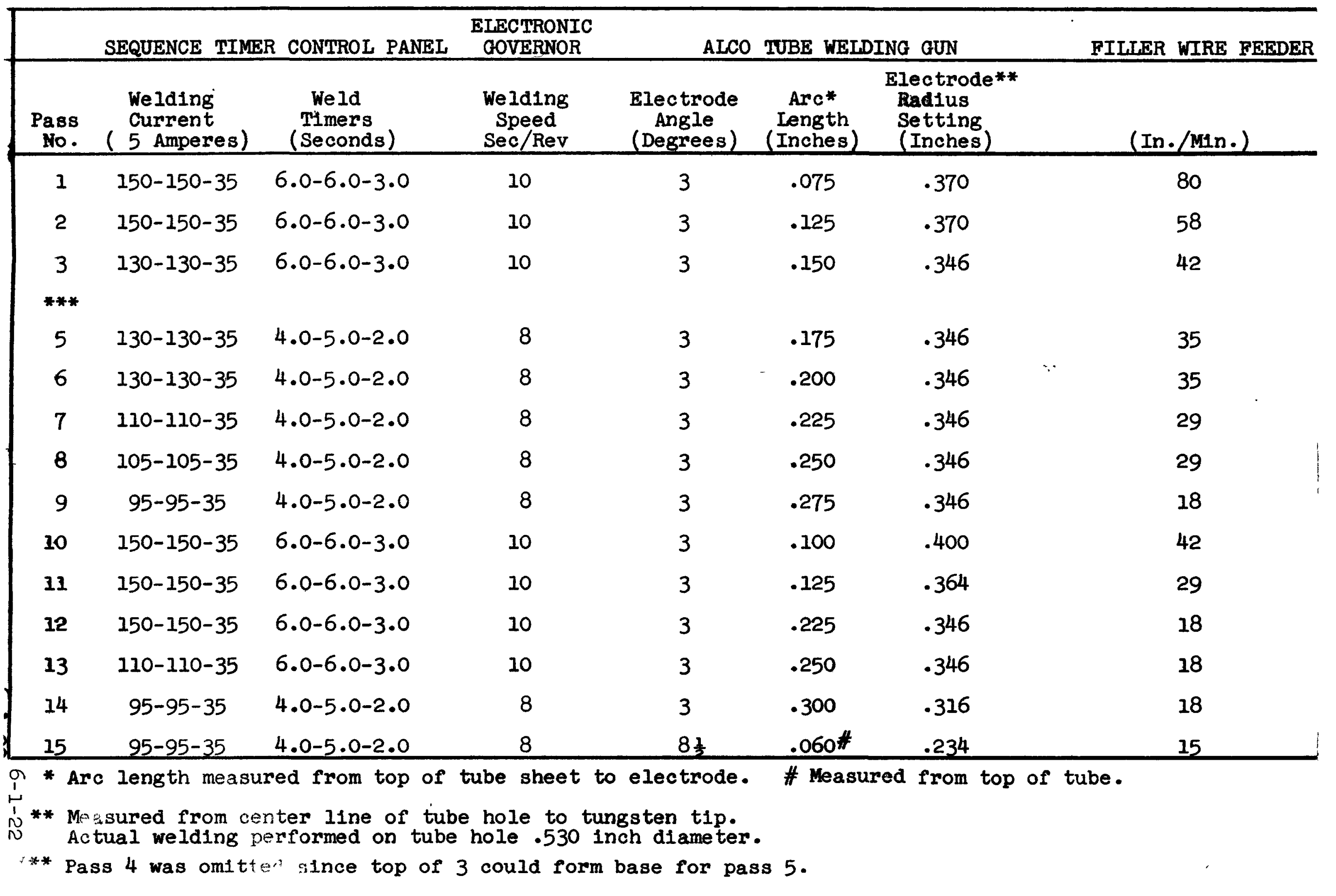




\section{SECTION 7}

\section{DRAWINGS AND MATERIAI IIST}

\section{INCLUDED DRAWINGS}

Page

F-42207-I-I-E Outline and General Assembly

$7-1-1$

F-42207-1-2-F Shell and Tube Sheet Details

$7-1-2$

F-42207-1-3-D Upper Channel Head Details

F-42207-1-4-F Baffle Assembly Deta1ls

F-42207-1-5-E Tubes - Layout, Welding and Bending Deta1ls

F-42207-1-6-D Shielding Details

F-42207-1-9-B Lower Channel Head Detalls

D-42207-1-21 Thermocouple Upper End Wiring Deta11

$7-1-3$

$7-1-4$

$7-1-5$

$7-1-6$

$7-1-7$

$7-1-8$

H-42207-1-22-C Instrument Orientation, Complete

$7-1-9$

Material Data Sheet - 42207 Page 1

Material Data Sheet - 42207 Page 2

$7-2-1$

$7-2-2$

Mater1al Data Sheet - 42207 Page 3

$7-2-3$

Materlal Data Sheet - 42207 Page 4

Materlal Data Sheet - 42207 Page 5

Material Data Sheet - 42207 Page 6

Materlal Data Sheet - 42207 Page 7

Material Data Sheet - 42207 Page 8

DRAWINGS NOT INCLUDED IN THIS REPORT

Temp. Recorder (G58 \& G59) Top Cover

Clips for Thermocouples

Temp. Recorder Igths. \& Arrg't.-Bundles (Tube Sheets)

Temp. Recorder Loths. \& Arrg't. of Bundles

Ordering Drawing- Iower Tube Sheet

Ordering Drawing- Upper Tube Sheet

12 " Nozzle - Ordering Drawing

Ordering Drawing for 7 " Channel Nozzles

Machining Details for Shell Nozzle Body (Nozzle H \& J)

Machining Detalis for Shell Nozzle Body (Nozzle G)

Detail Instrument Orientation (VIew $Y-Y$ )

$B-42207-1-10$

B-42207-1-11

B-42207-1-12

C $-42207-1-20$

C-42207-1-50

C-42207-1-51

C-42207-1-55

C-42207-1-57

Ordering Details - Lower \& Upper Head Detalls

D-42207-1-7

D-42207-1-8

D-42207-1-21

D-42207-1-58 


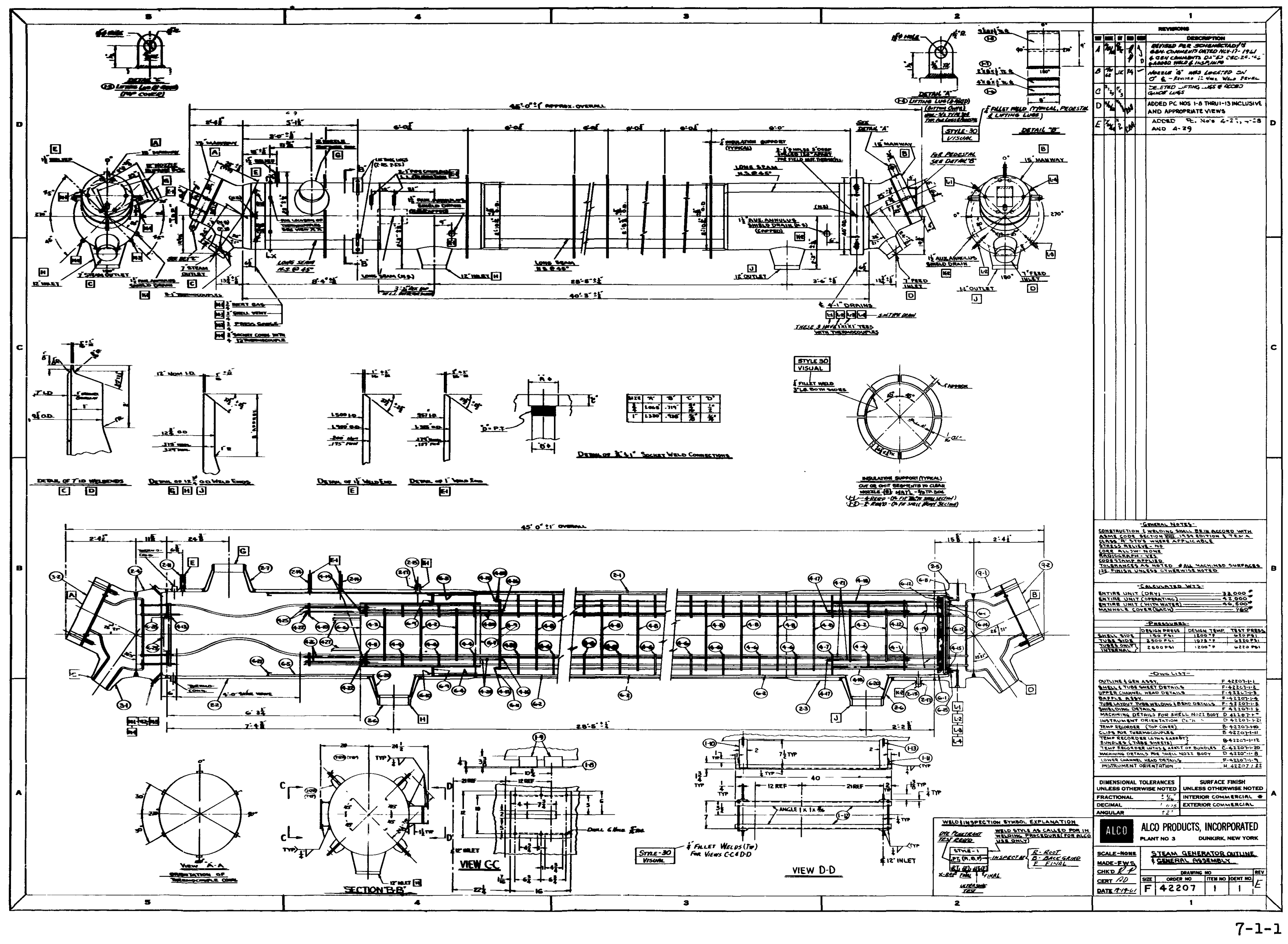




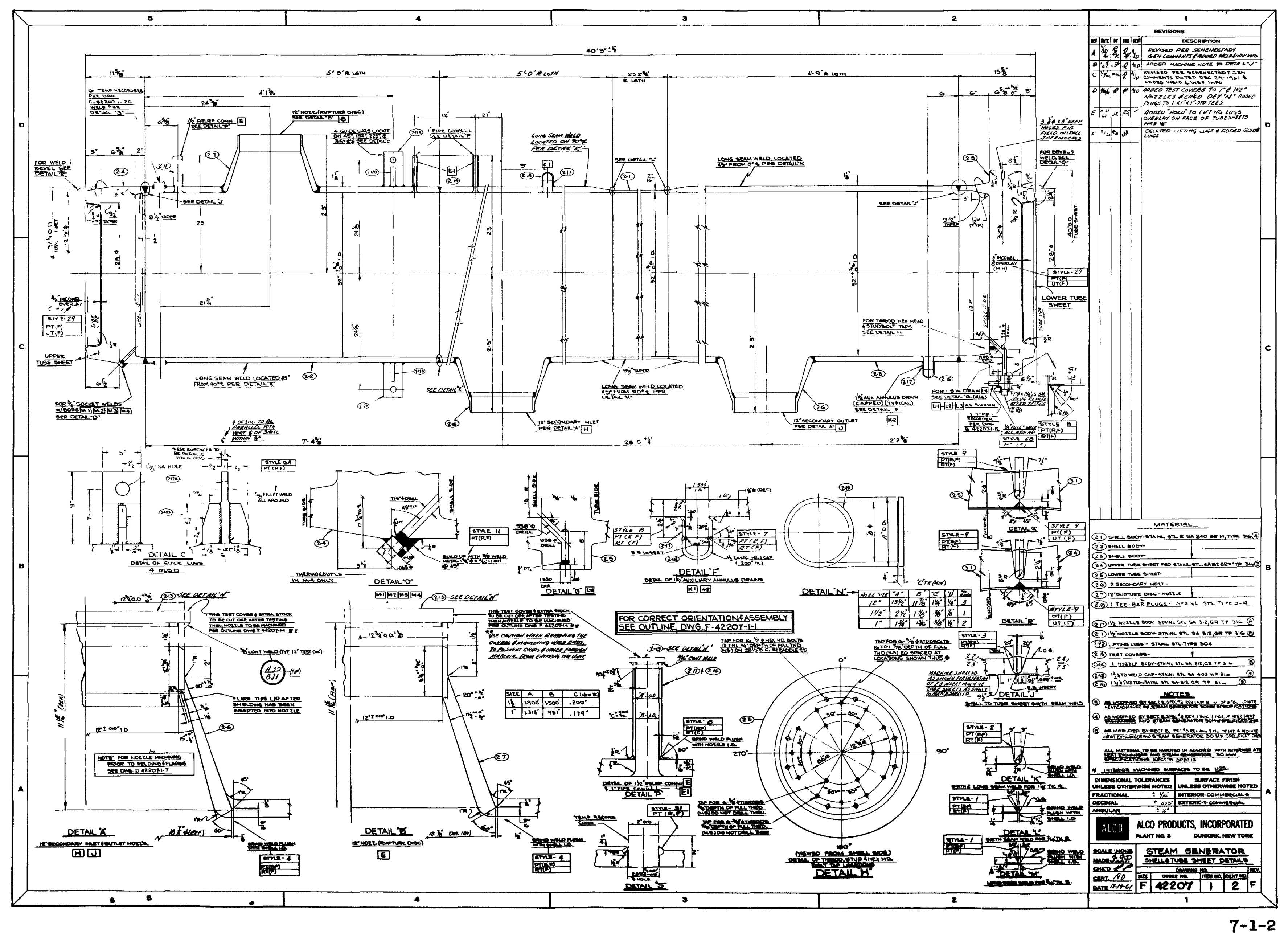




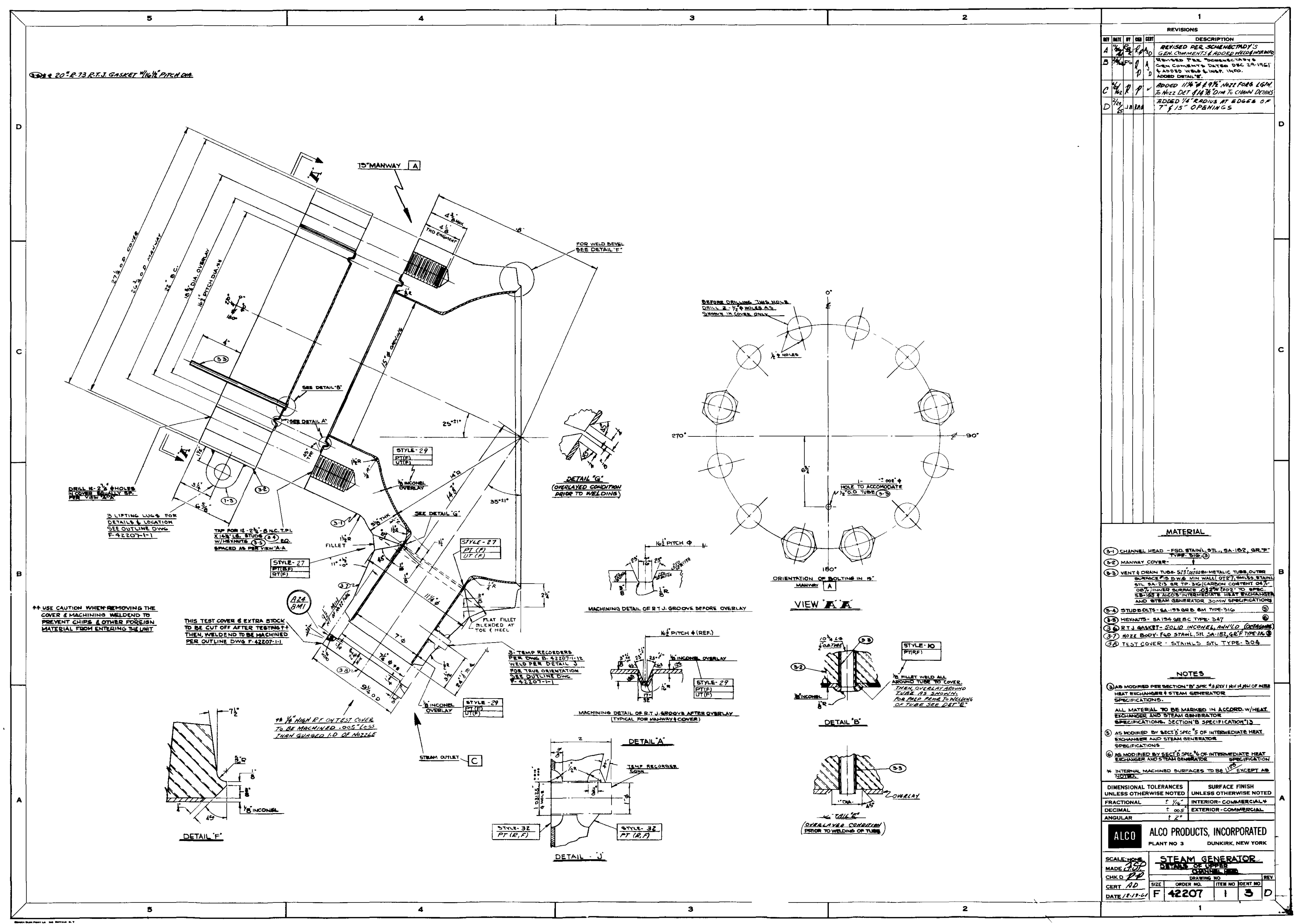




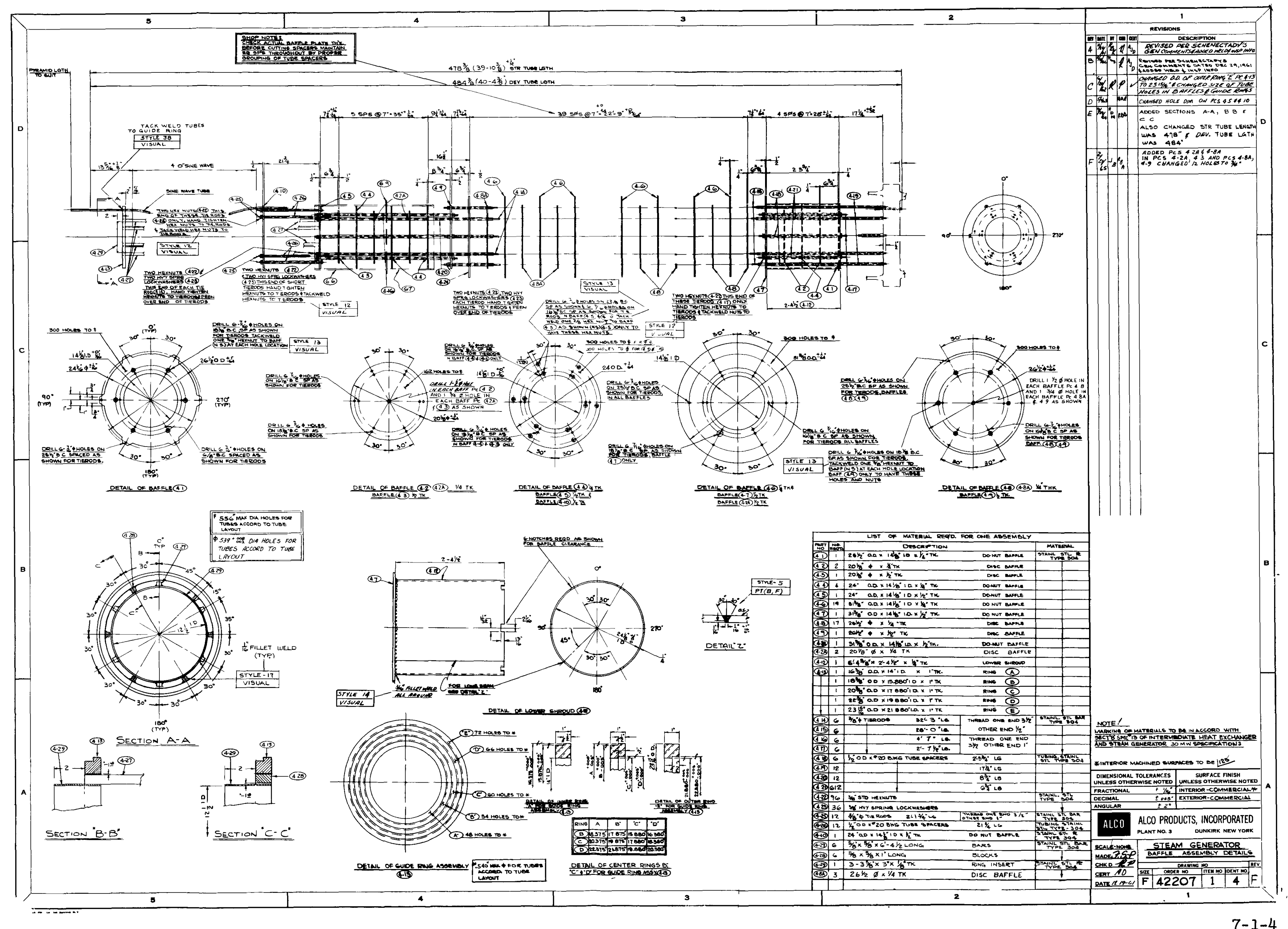




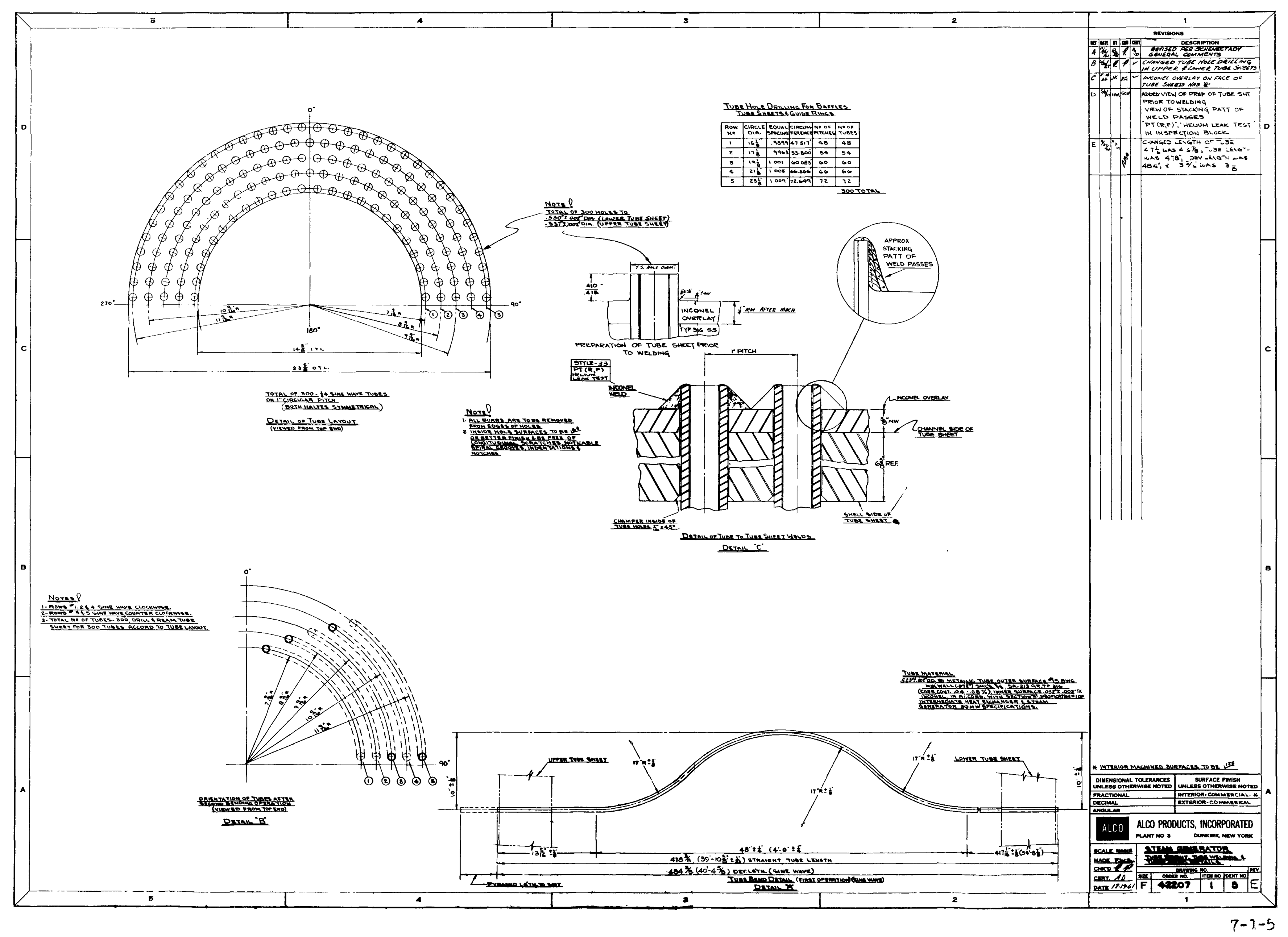




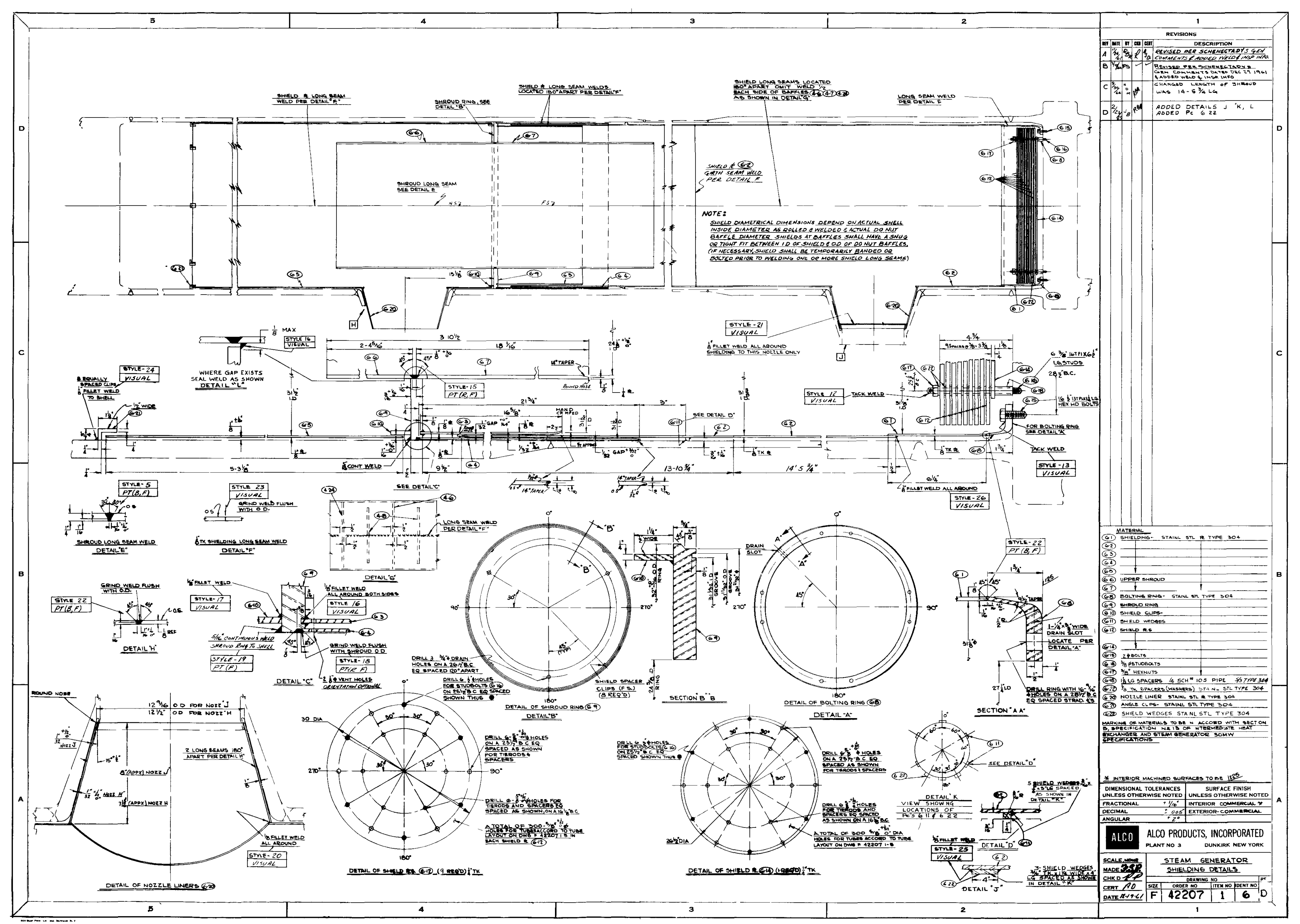




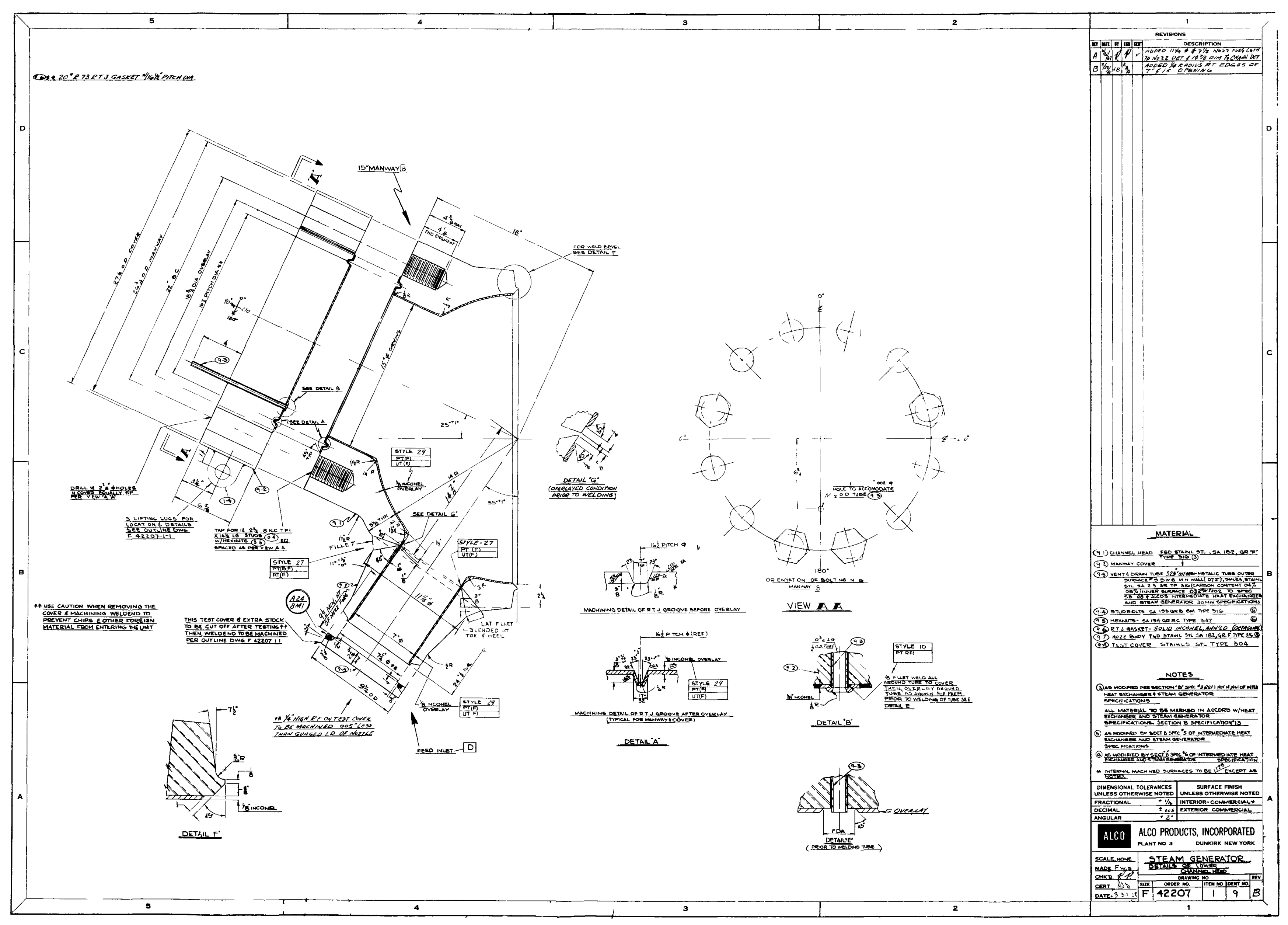




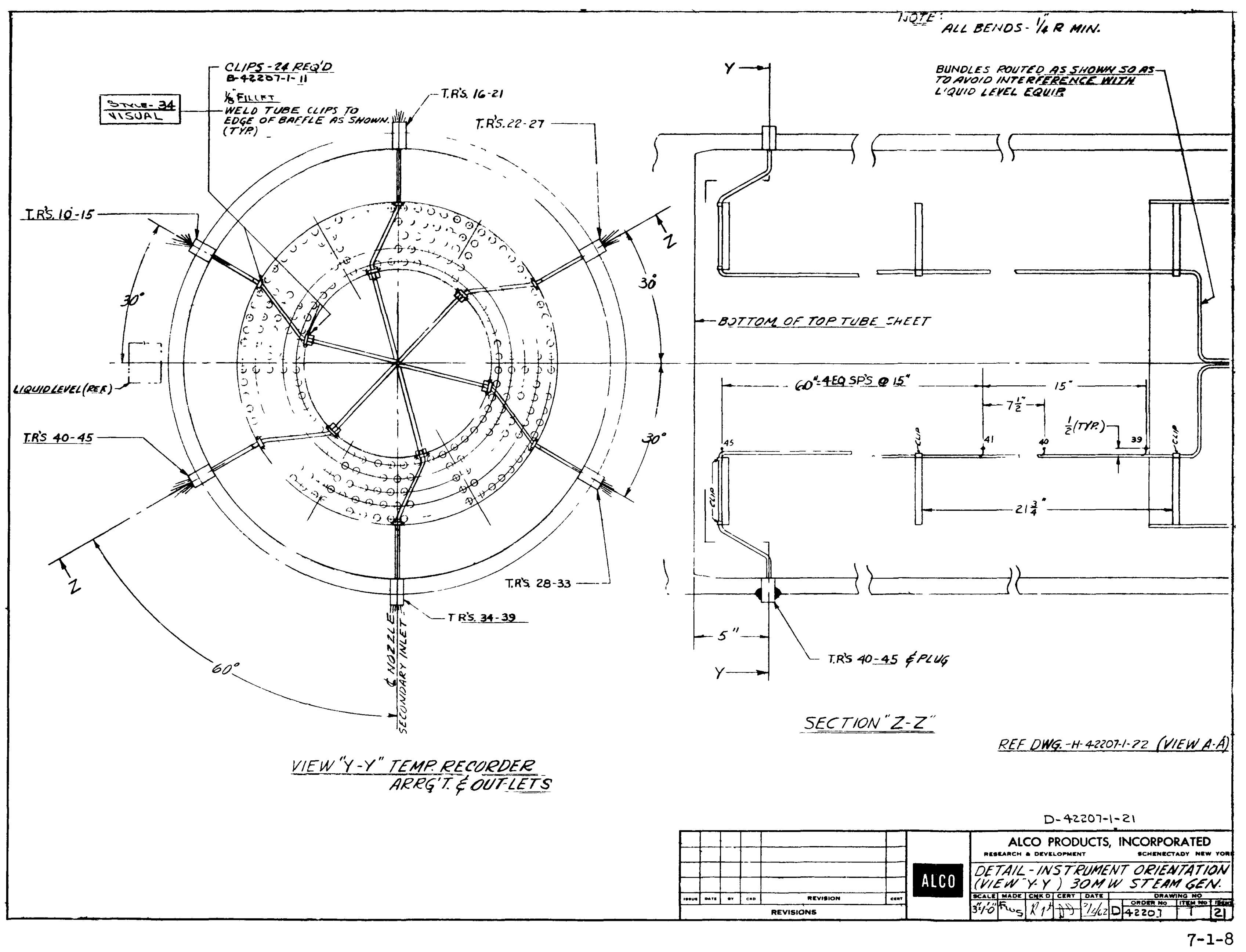




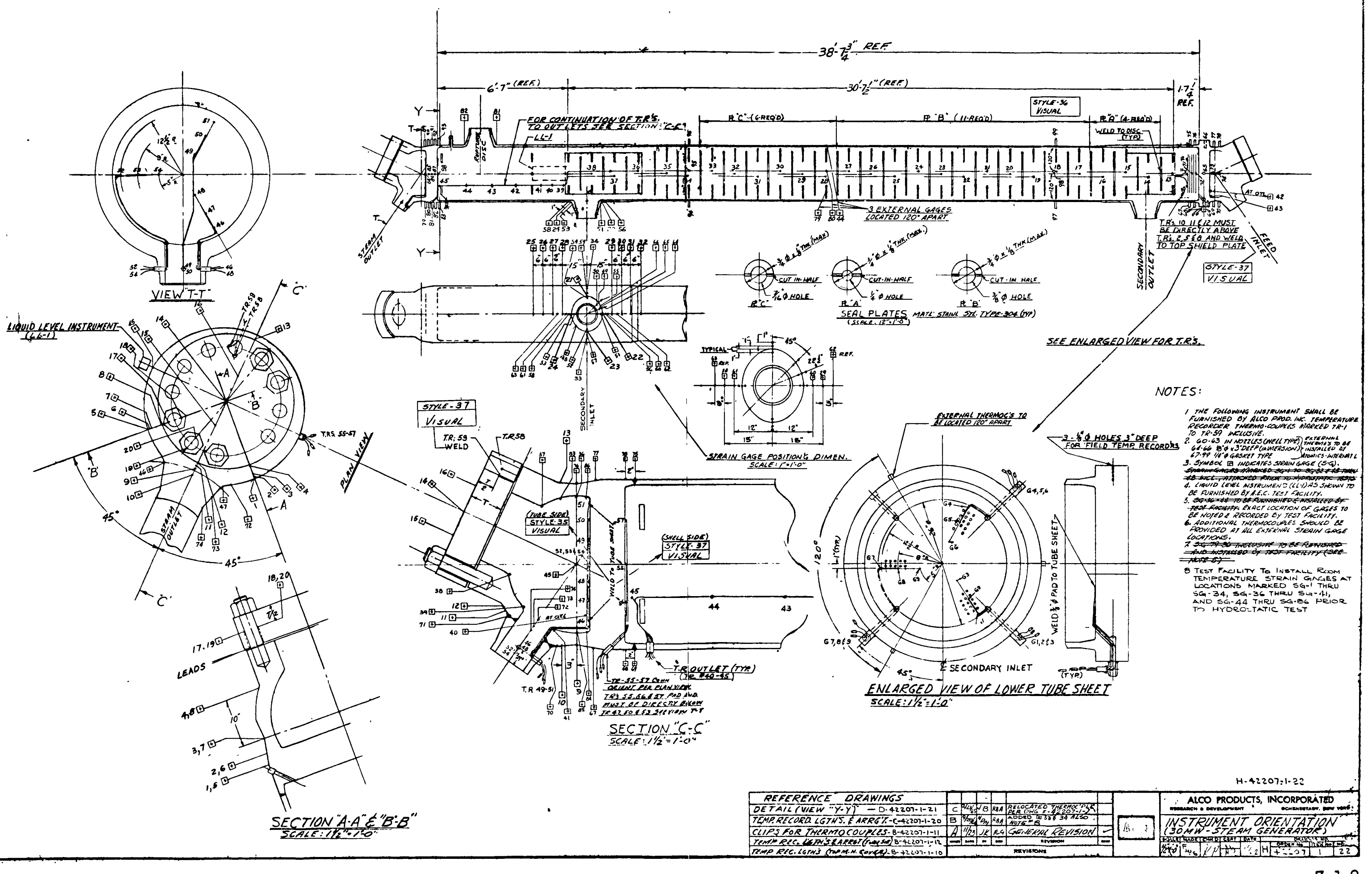


ALCO PRODUCTS, INCORPORATED

EXCHANGER CONSTRUCTION and MATERIAL DATA SHEET

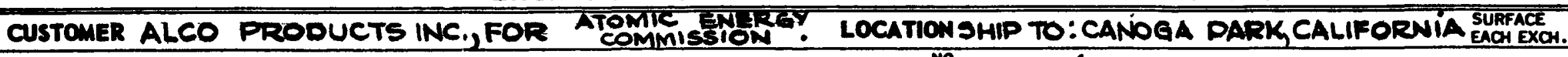

REO.D(I) ONE SIZE SPECIAL. TYPE SPECIAL.

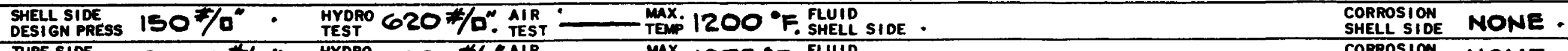

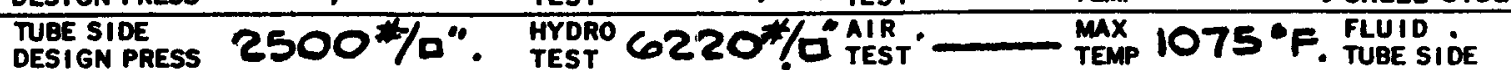

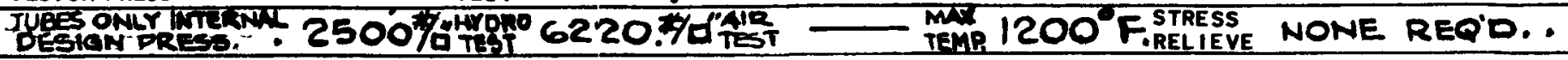

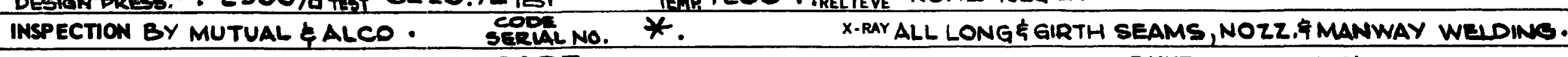

REMARKS * CODE STAMP BY MUTUAL . CODE SEE LINES 1,2 \& 3 .

PANT NONE REQD.

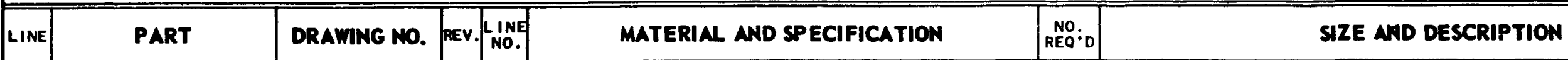

1 CONSTRUCTIONE WELDINE TO BE IN ACCORD. WITH A.S.M.E. CODE, SECTION YIII,

21959 EDITION \& TEMA \&L: R" STDS. WHERE APPLICABLE. - ALCO'S"INTERMEDIATE HEAT EXCHANGER AND

3 STEAM GENERATOR $30 \mathrm{NW}$ SRECIFICATIONS ALSO APPLY.

4 MATERIAL NQTES-

5 NOTE I! AS MODIFIED BY SECTION "B"; SPECIFICATION NO. 1, REV. AUG. 9, 1961, OF INTERMEDIATE HEAT

6 EXCHANGER \$ STEAM GENERATOR 30 MW SPEKIFICATIONS.

7 NOTE-3! AS MODIFIED BY \$ECTION "B", SPECIFICATION N0.3 REV.I NOV.14,1961, OF INTERMEDIATE HEATEXCH. \&STEAM

8 GENERATOR zOMW SPECIFICATIONS.

10 NOTE-4! AS MODIFIED \&Y SECTION 'B;, SPECIFICATION N0.4 REV.I NOV. 14,1961 OF INTERMEDIATE HEATEXCH. \& STEAMI

11 GENERATOR 3ONIW SPECIFICATIONS.

13 NOTE-5! AS MODIFIED BY SEETION "B", SPECIFICATION NO.S OF INTERIMEDIATE HEAT EXCHANGER AND STEAM

14 GENERATOR BOMN SPECIFICATIONS.

16 NOTE-6! A\$ MODIFIED BY SECTION "B", SPECIFICATION N0.6 OF INTERMEDIATE HEAT EXCHANGER AND STEAM

17 GENERATOR jO MU SPECIFICATIONS.

18 NOTE-8!

19 ULTRASONIC INSPECTION TO BE IN ÁCCORD. WITH SECTION "B', SPECIFICATION No. 8 , REV. AU G. 9 , 1961, OFINTER. HEAT

20 EXCHANGER AND STEAM \$ENIERATOR $30 \mathrm{MW}$ SPECIFICATIONS.

21 MARKING NoIE-

22 ALL MATERIALS TO BE MARKED IN ACCORD. WITH SECTION "B", SPECIFICATION"I3 OF INTERMEDIATE HEAT

23 EXCHANGER AND STEAM GENERATOR 3O MW SPECIFICATIONS.

24 .

\begin{tabular}{|l|}
25 \\
\hline 26
\end{tabular}
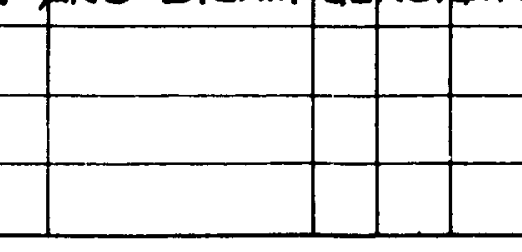

\begin{tabular}{|l|}
\hline \\
\hline
\end{tabular}

$+$

-

\begin{tabular}{l|l|l|l|l|l} 
& & & & & \\
\hline & & & & & \\
& & & & &
\end{tabular}

I




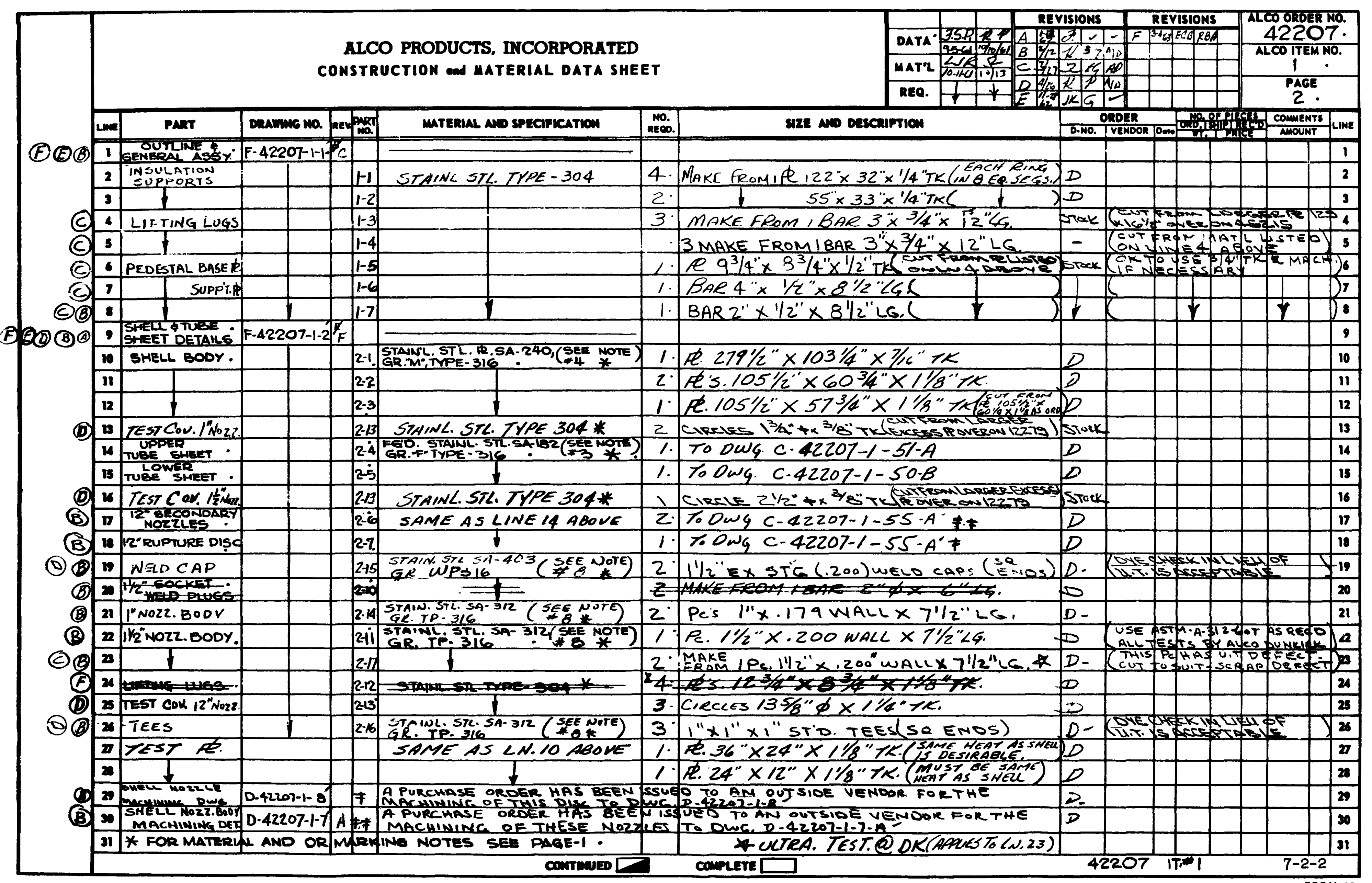


ALCO PRODUCIS, INCORPORATED

CONSTRUCTION on MATERIAL DATA SHEET

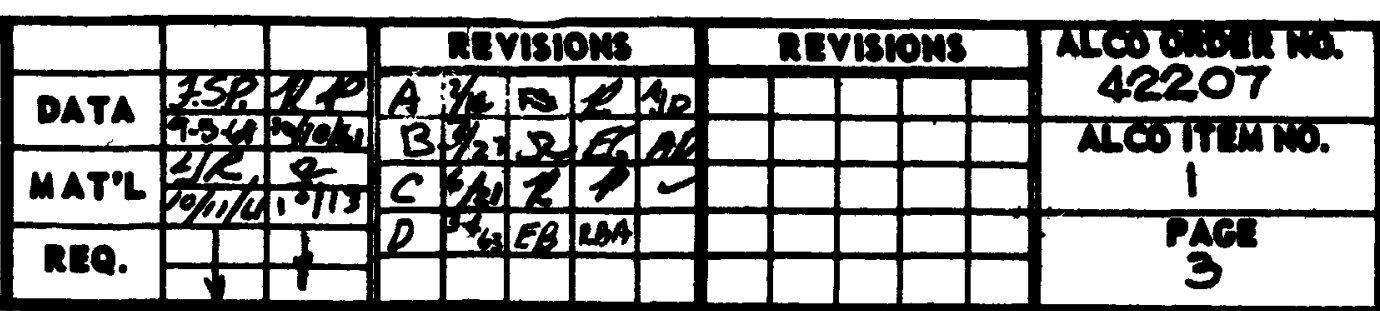

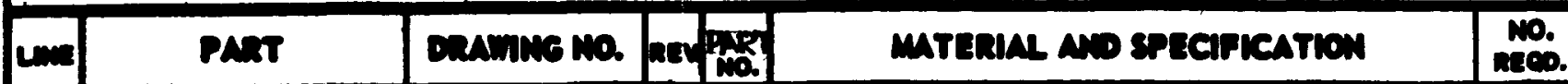

eze ano orscalption

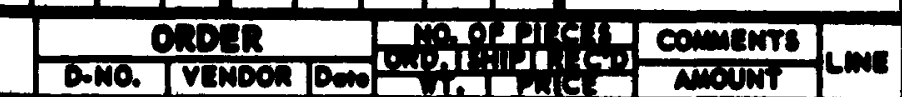

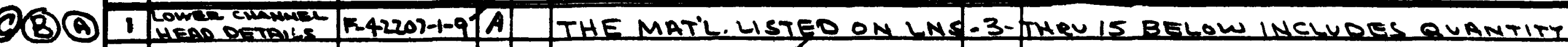

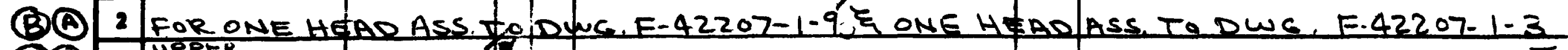

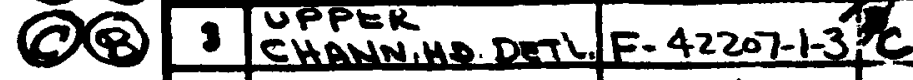

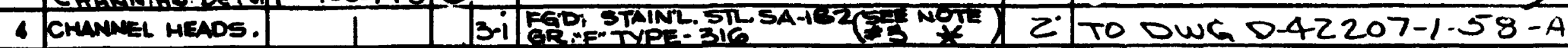

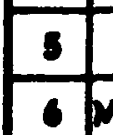

\begin{tabular}{|c|c|c|c|c|}
\hline & $3-i$ & 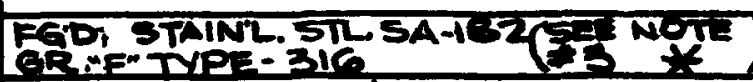 & 2 & TO OWG $0.42207-1.58-A$ \\
\hline & & & & \\
\hline & $3-2$ & & $2^{\circ}$ & 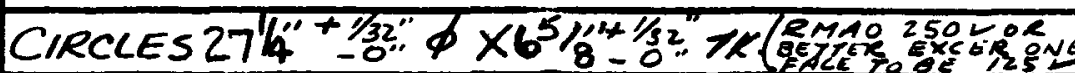 \\
\hline
\end{tabular}

7 TEST COVER

3-2

. TYPE 304 2 CIRCLE: 93/8'\$X29/16'MINTK.

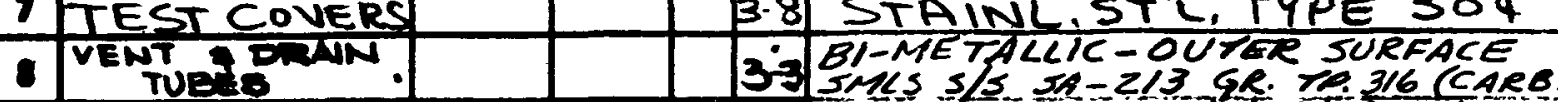

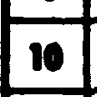

Tha ST

SUKFACE $\$ .032$ t.00L" TA: INAILE SURFACE BY INTERMEDIATE HEAT EXCHANGER .

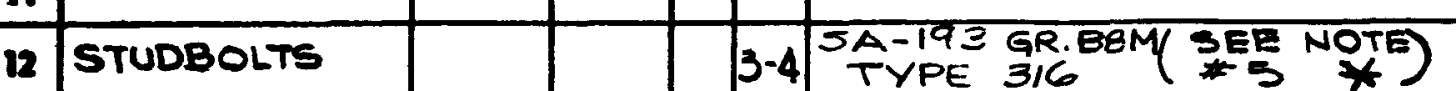

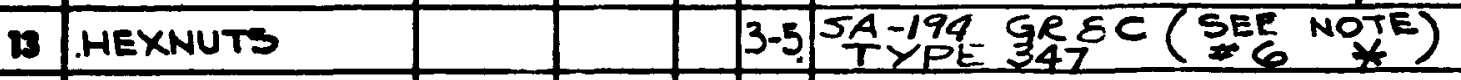

$2423 / 4 " \phi \times 141 / 4 " L G .8 T P /-1 / L$

\begin{tabular}{l|l}
\hline HEXNUTS \\
\hline R.T.J. GASKET
\end{tabular}

IS NOZZLE

$24.23 / 4$ AM. $570 \cdot 11$ NY. SER. 8TPI

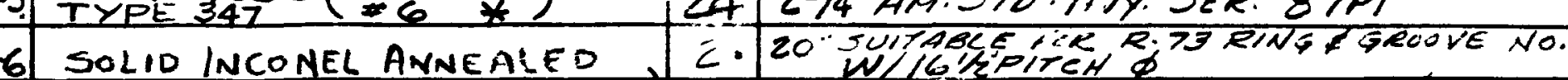

16 Baffle Assembirf F-42207-1-4

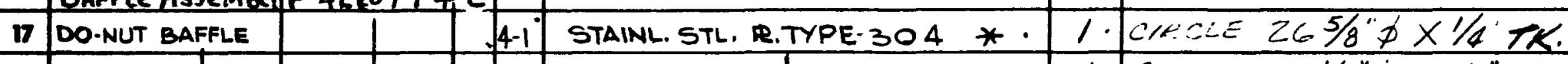

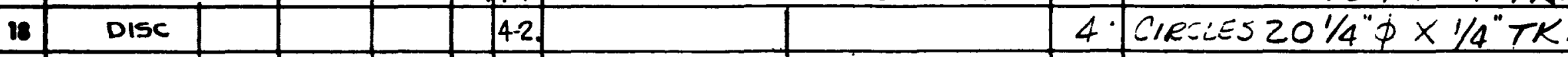

\begin{tabular}{l|l|l|l|l|l|l|l|l}
19 & DISC & & & & & & & \\
\hline
\end{tabular}

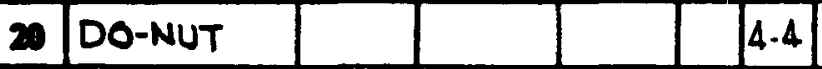

21 DONUT

2 DO-NUT

23 DONUT

\begin{tabular}{|l|l|l|}
\hline 24 & DisC \\
\hline 25 & DisC
\end{tabular}

25 DISC \begin{tabular}{|l|l|}
\hline 26 & DO-NUT \\
\hline
\end{tabular}

(E)

20 LOWER SHROUD

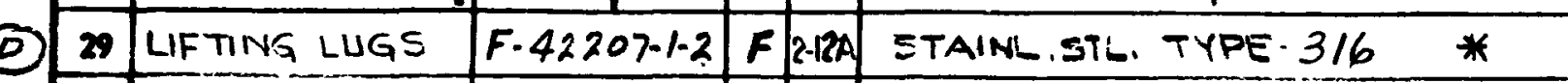

(e) 30 LIFTING LUGS F-42207-1-2 F RRB STAINL, STL. TYPE-3/6 *

31 * FOR MATERIAL AND, OR MARKING NOTES SEE PAGE-1

4 CIRCLES $241 / 8 \phi \times 1 / 4$ TK.

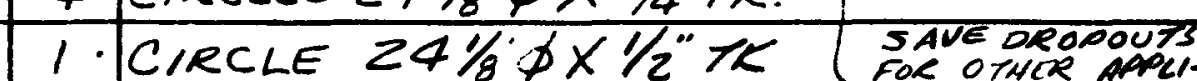

19. CIRCLES 3/1/2" $\phi X 1 / 4$ "TK. CAIIONS-TNIS JOX.

1. CIRCLE $3 / 1 / 2 " \phi \times 1 / 2 " T K$.)

20.CIRCLES $265 / 8^{\prime \prime} \phi \times 1 / 4 " T K$.

1 CIRCLE $265 / 8 " \phi \times 1 / 2 " 1 K$.

1. CIRCLE 3I/2" $\phi \times 1 / 2 " 1 K$ :

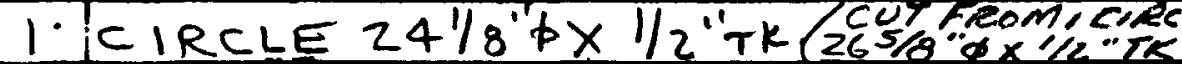

1. R. 773/4" X 291/4" $\times 1 / 4 " T K$.

4 '它 $9^{\prime \prime} \times 5^{\prime \prime} \times 11 / 4$ THK

8 Q'S $53 / 4 \times 31 / 4 \times 1 \frac{1}{8}$ THK COROM FROM OROPOUTS

$\$$

\begin{tabular}{ll|l|l|l|l|l|l|}
\hline & & & & & & & \\
\hline
\end{tabular}

\begin{tabular}{ll|l|l|l|l|l|l|l|}
\hline & & & & & & & & 3 \\
\hline
\end{tabular}

D

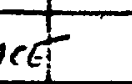




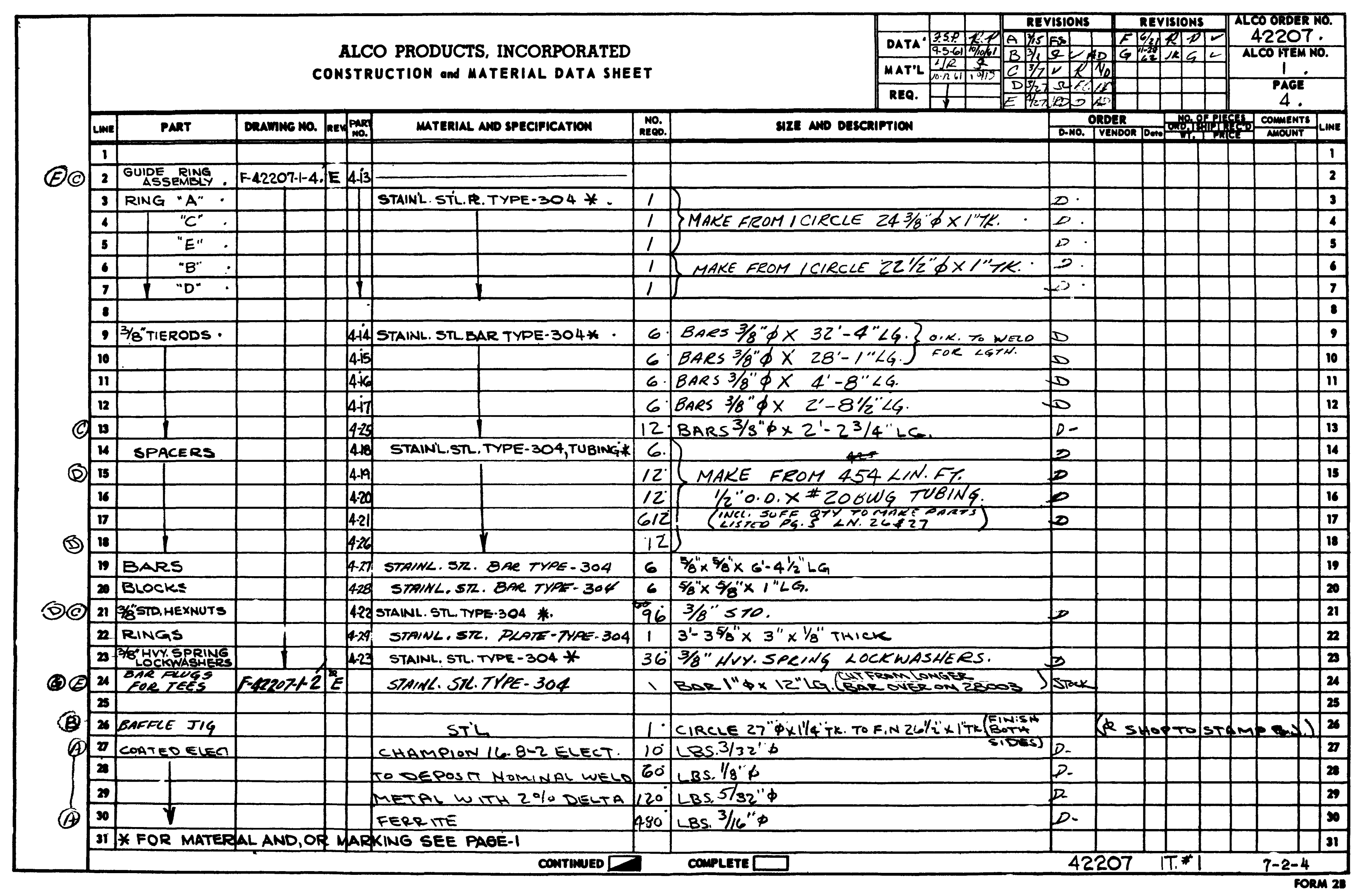


ALCO PRODUCTS, INCORPORATED CONSTRUCTION and MATERIAL DATA SHEET

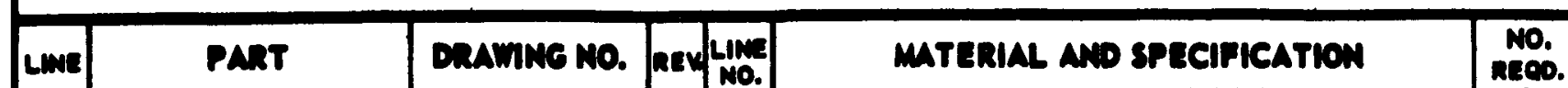

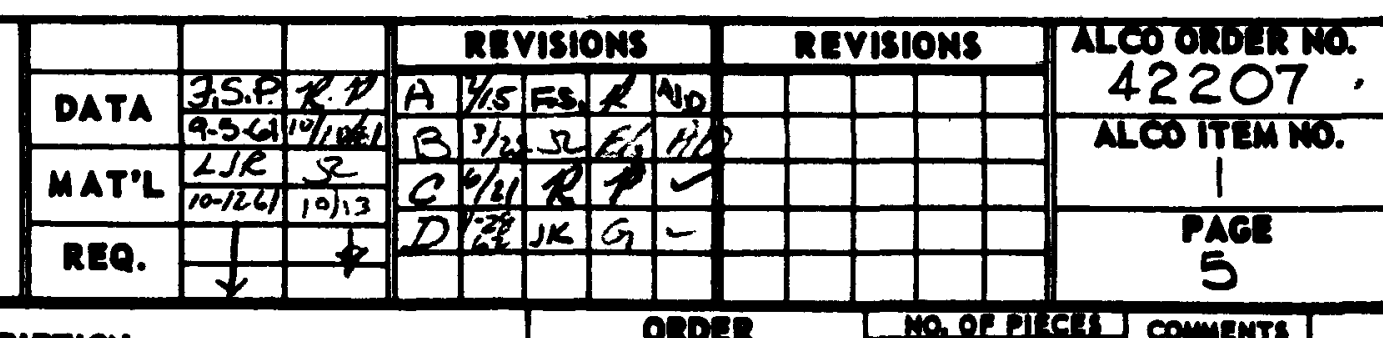

SIE ano orscription

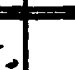

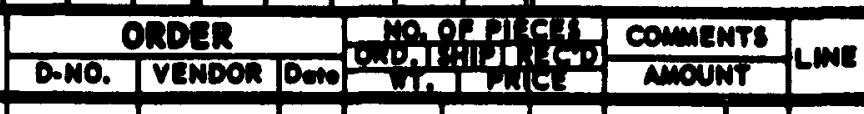

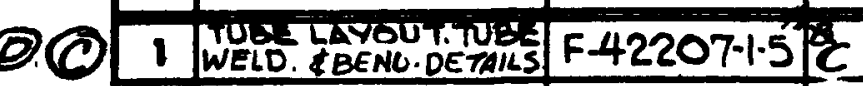

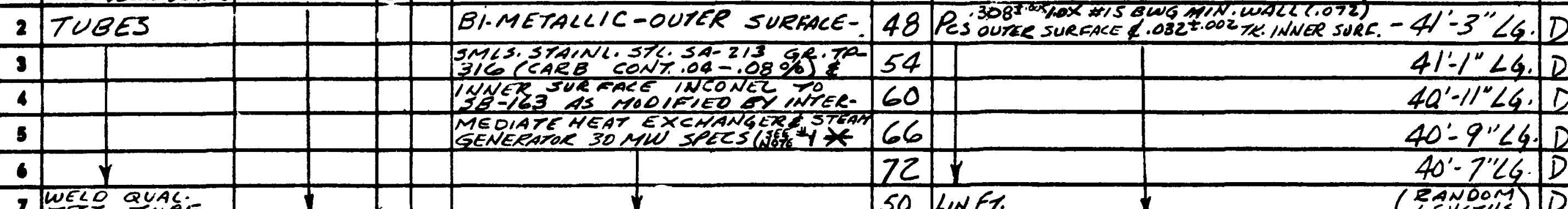

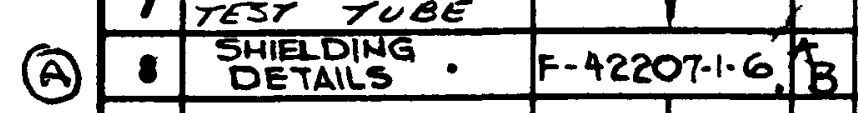
SHIELING

(Q)

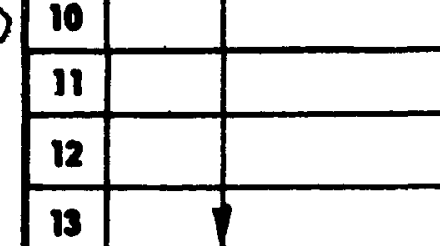
50 LIN FA.

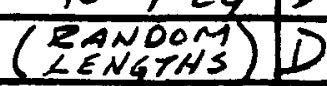

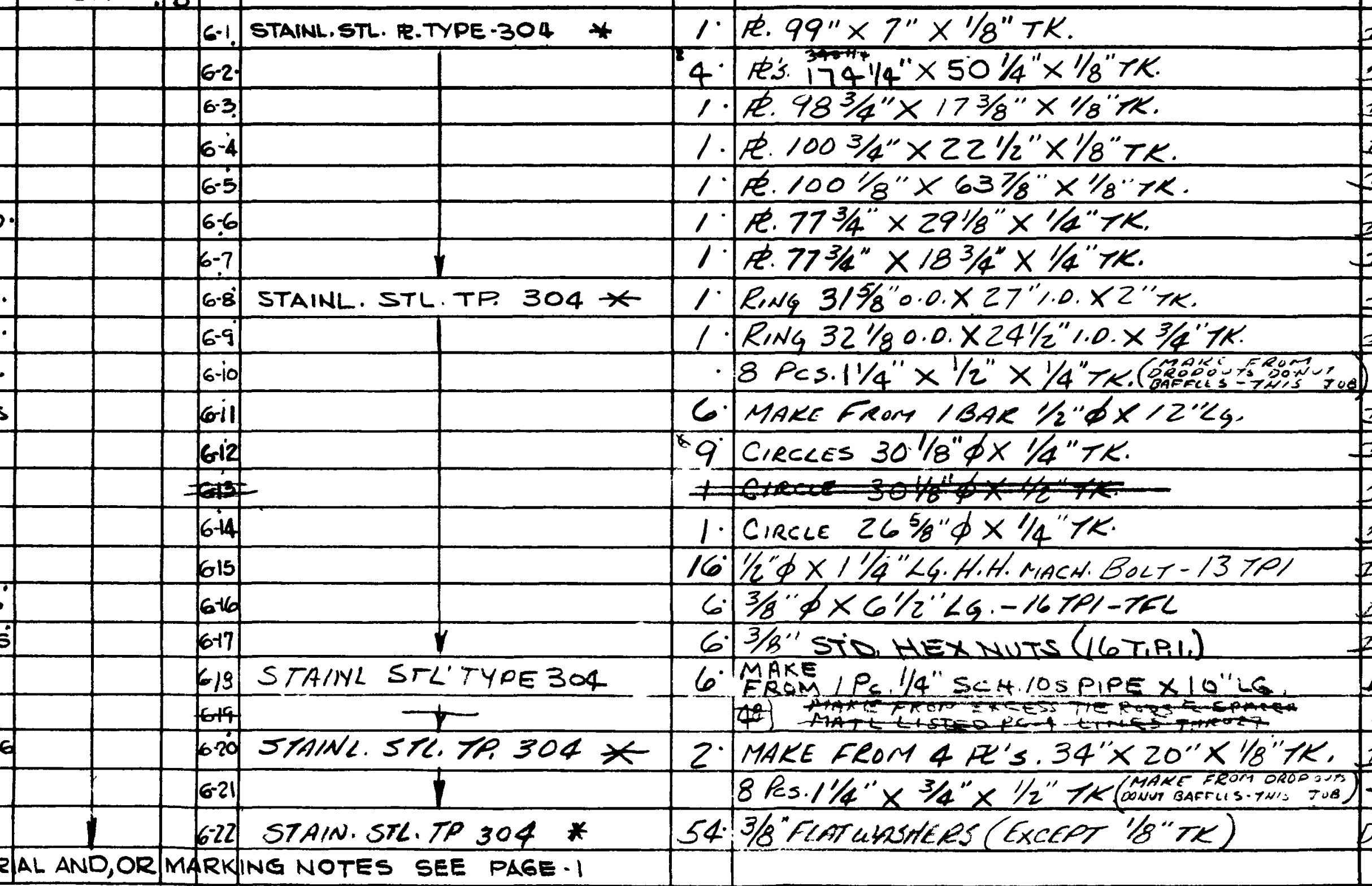

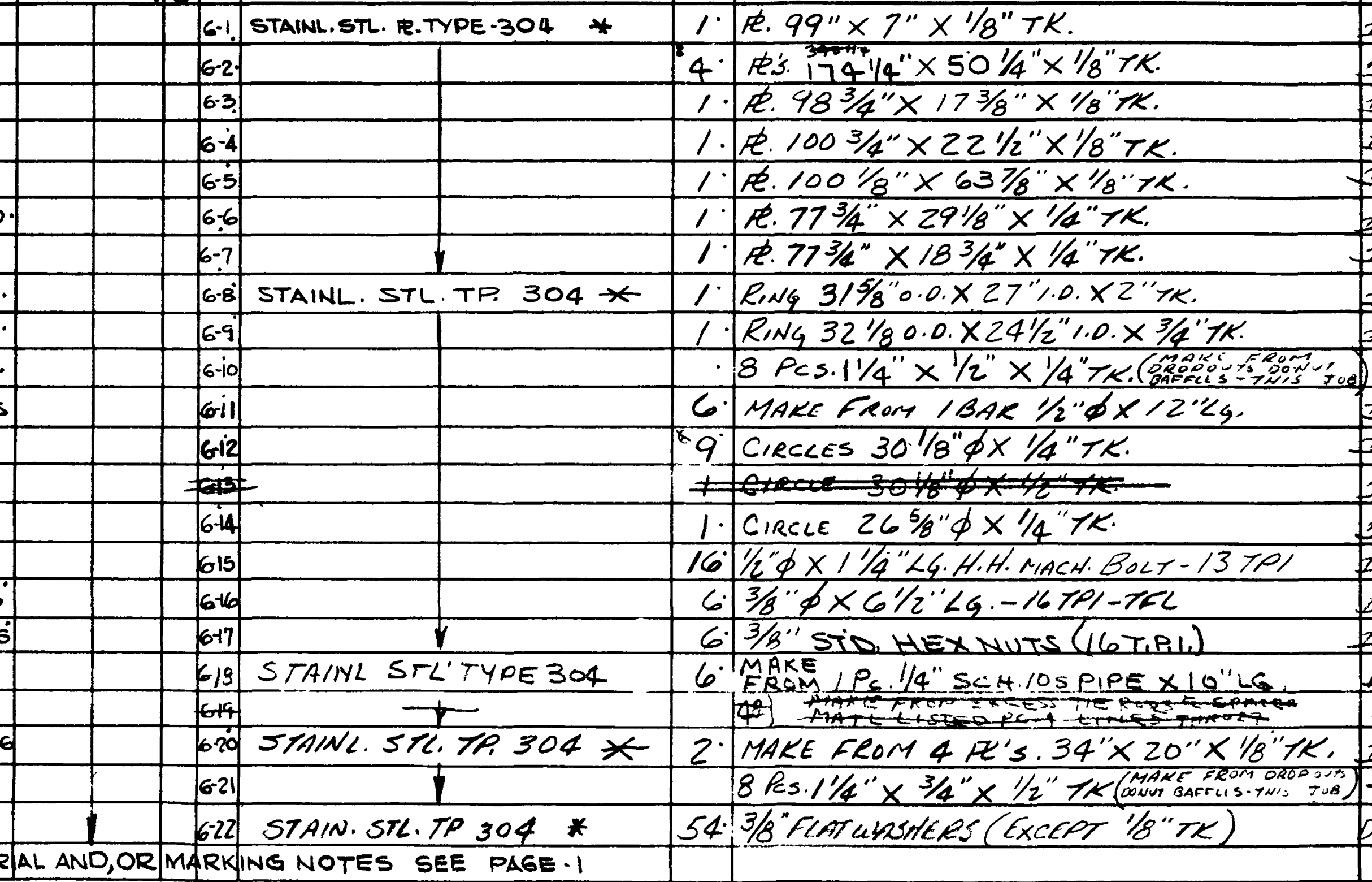
CONTINUED
COMPLETE

D.w.

D.

$D$.

\begin{tabular}{llllllll}
$D \cdot$ & & & & & & & 4 \\
\hline
\end{tabular}

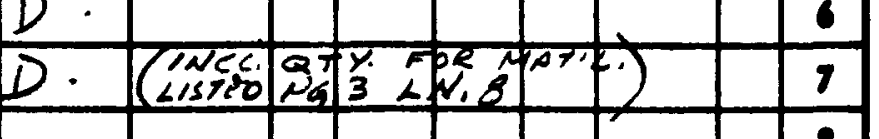

14 UPPER SHROUD

I5

16 BOLTING RING

17 SHROUD RING

18 SHIELD CLIPS

19 SHIELO NEDGES

(B) 20 SHIELD R'S

(B) $21 \quad \exists$

(B)

23 1/2" $\$$ BOLTS -

$247 / 8$ " $\$$ STUDBOLTS

(B) 25 (8TD.HEXNUTS

25 7/8 STD. HEXNUTS

(B) 27 //4" spacers .

28 NOZZ. SHIELDINE

29 ANGLE CLIPS.

(a) 30 WASHERS 31 * for mater al and, or marking notes see page - 


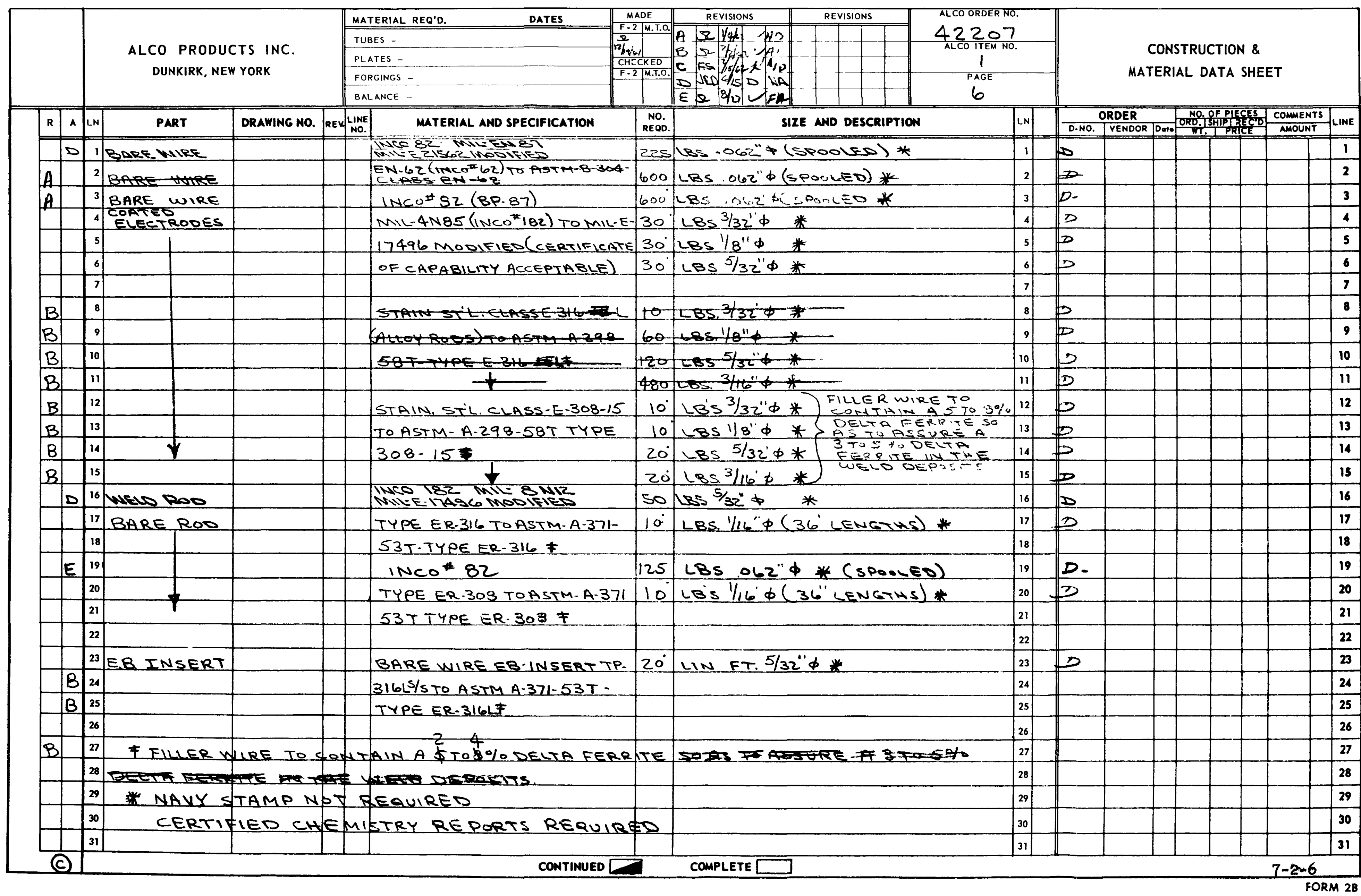


ALCO PRODUCTS, INCORPORATED CONSTRUCTION and MATERIAL DATA SHEET

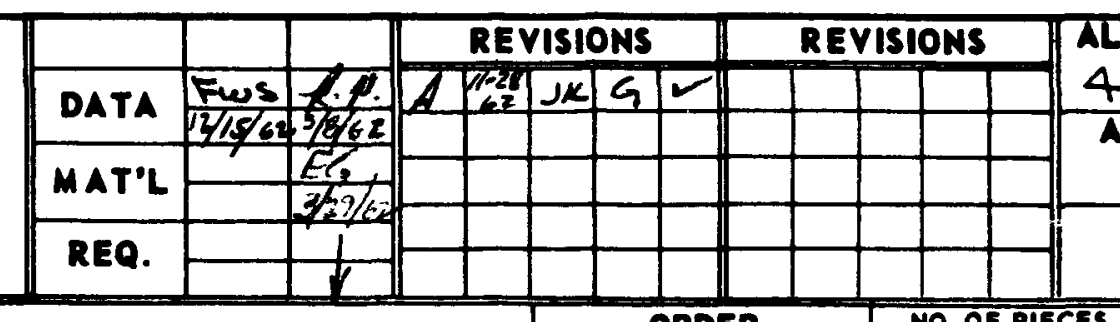

\begin{tabular}{|c|c|c|c|c|c|c|c|c|c|c|c|}
\hline \multirow[t]{2}{*}{ Line } & PART & DRAMMG NO. & \begin{tabular}{l|l|l|} 
REV & LMOE. \\
\end{tabular} & \multirow[t]{2}{*}{ MATERIAL AND SPECIFICATION } & \multirow[t]{2}{*}{$\begin{array}{l}\text { NO. } \\
\text { REOO: } \\
\end{array}$} & SIZE AND DESCRIPTION & \multicolumn{2}{|c|}{ ORDER } & 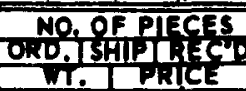 & $\begin{array}{l}\text { COMMENTS } \\
\text { MOUNT }\end{array}$ & \multirow{2}{*}{$\begin{array}{l}\text { LINE } \\
1\end{array}$} \\
\hline & $\begin{array}{l}\text { IASTROMENT } \\
\text { ORIENTATIOA }\end{array}$ & $H-42207-1-22$ & \begin{tabular}{|l|l|l|}
$A$ & \\
\end{tabular} & & & & & & & & \\
\hline 2 & SEAL KA "A" & & & STAINL. STL. TYPE-304 & 4 & LMAKE FROM IBAE $=14^{\prime \prime} \Rightarrow \times 19^{\prime \prime} L G$ & & & & & 2 \\
\hline 3 & $\mid E^{\prime \prime}$ & & & & 11 & $\sum$ & & & & & 3 \\
\hline 4 & $c^{\circ}$ & & & 1 & 6 & & & & & & 4 \\
\hline 5 & STRAN GAGES & & & & & LATPM & & & & & 5 \\
\hline 6 & E.L.INSTRUM. & $y$ & & FURNCSHED BY A.E.C. & & ANO CHARE $=$ P.O HAS BEEN & D- & & & & 6 \\
\hline 7 & & & & & & ISSUED TOA.E.C. FORTHIS PART & & & & & 7 \\
\hline 8 & DET.INST:0RIRAT & $D-42207 \cdot 1-21$ & & REF. & & & & & & & 8 \\
\hline 9 & & & & & & & & & & & 9 \\
\hline 10 & & & & & & & & & & & 10 \\
\hline 11 & & & & & & & & & & & 11 \\
\hline 12 & $\begin{array}{l}\text { TEMP RECORD. } \\
\text { LGTH'S. LARR'G'T }\end{array}$ & $B-42207-1-12$ & & $=$ & & A NO CHARSE PURCHASE & P- & & & & 12 \\
\hline 13 & SHEATHS GITHRUG-G & & & STAINL. STL. TYPE- $3 / 6$ & & oroer has beEN ISSUED & & & & & 13 \\
\hline 14 & \begin{tabular}{|l|l|} 
ESS.CONN. & \\
\end{tabular} & & & & & TO ALCO, SCHENECTAOY FOR & & & & & 14 \\
\hline 15 & $\begin{array}{l}\text { BANDSE } \\
\text { WECOAPAD Y }\end{array}$ & & & 1 & & THESE PARTS & & & & & 15 \\
\hline 16 & 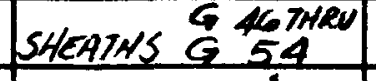 & & & INCONEL B-163 & & & & & & & 16 \\
\hline 17 & \begin{tabular}{|l|l|} 
VESS,CONN, & \\
\end{tabular} & & & & & & & & & & 17 \\
\hline 18 & BANDS & & & 4 & & & & & & & 18 \\
\hline 19 & WELO PAD 1 & & & $\angle N C O N E L B \cdot 168$ & & & & & & & 19 \\
\hline 20 & & & & & & & & & & & 20 \\
\hline 21 & $\begin{array}{l}\text { TUPS FOR } \\
\text { THERMOCOUPLES }\end{array}$ & $B-42207-1-11$ & & STAINL. STL. TYPE 304 & $\begin{array}{ll}A S \\
\text { REOD }\end{array}$ & 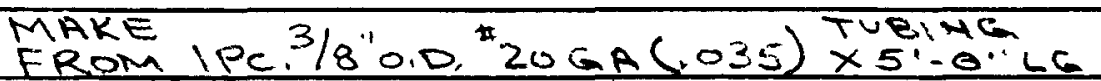 & D_ & & & & 21 \\
\hline 22 & & & & & & & & & & & 22 \\
\hline 23 & $\begin{array}{l}\text { TEMP.RECORD. } \\
\text { JOA COVER }\end{array}$ & $B-422071-10$ & & - & & ANO CHEM IE PURCHASE OROER & D- & & & & 23 \\
\hline 24 & SHEHTH G 6252 & & & STHUNG. STE. TYPE $3 / 6$ & & HAS BEEN ISSUED TOALCO, & & & & & 24 \\
\hline 25 & PAD i & $\perp$ & & 1 & & SCHEN FOK THESE PARTS & & & & & 25 \\
\hline 26 & & & & & & & & & & & 26 \\
\hline$\cdot \boldsymbol{n}$ & 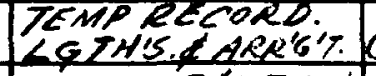 & $c=42207.20$ & & $=$ & & A NO CHAREE PURCHASE & $0-$ & & & & 27 \\
\hline 28 & SHEATH G\% THE & & & STHINL. STL. TYPE 316 & & I ORDER HAT EEEH! ISSIED TO & & & & & 28 \\
\hline 29 & \begin{tabular}{|l|l|} 
Kess.Coner & \\
\end{tabular} & & & & & 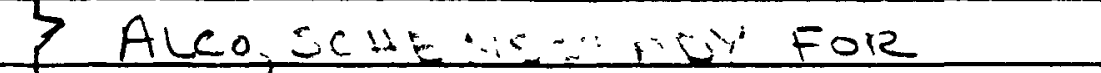 & & * & & & 29 \\
\hline 30 & BANOS & & & & & THESE PHWT: & & & & & 30 \\
\hline 31 & HKLOPRO.G:10\%1/12] & 1 & & & & & & & & & 31 \\
\hline & & & & CONTINUED & & COMPLETE $\square$ & & 42 & $-207=1$ & $7-2-7$ & \\
\hline
\end{tabular}


SECTION 8

FABRICATION PHOTOGRAPHS

\begin{tabular}{|c|c|}
\hline & Page \\
\hline 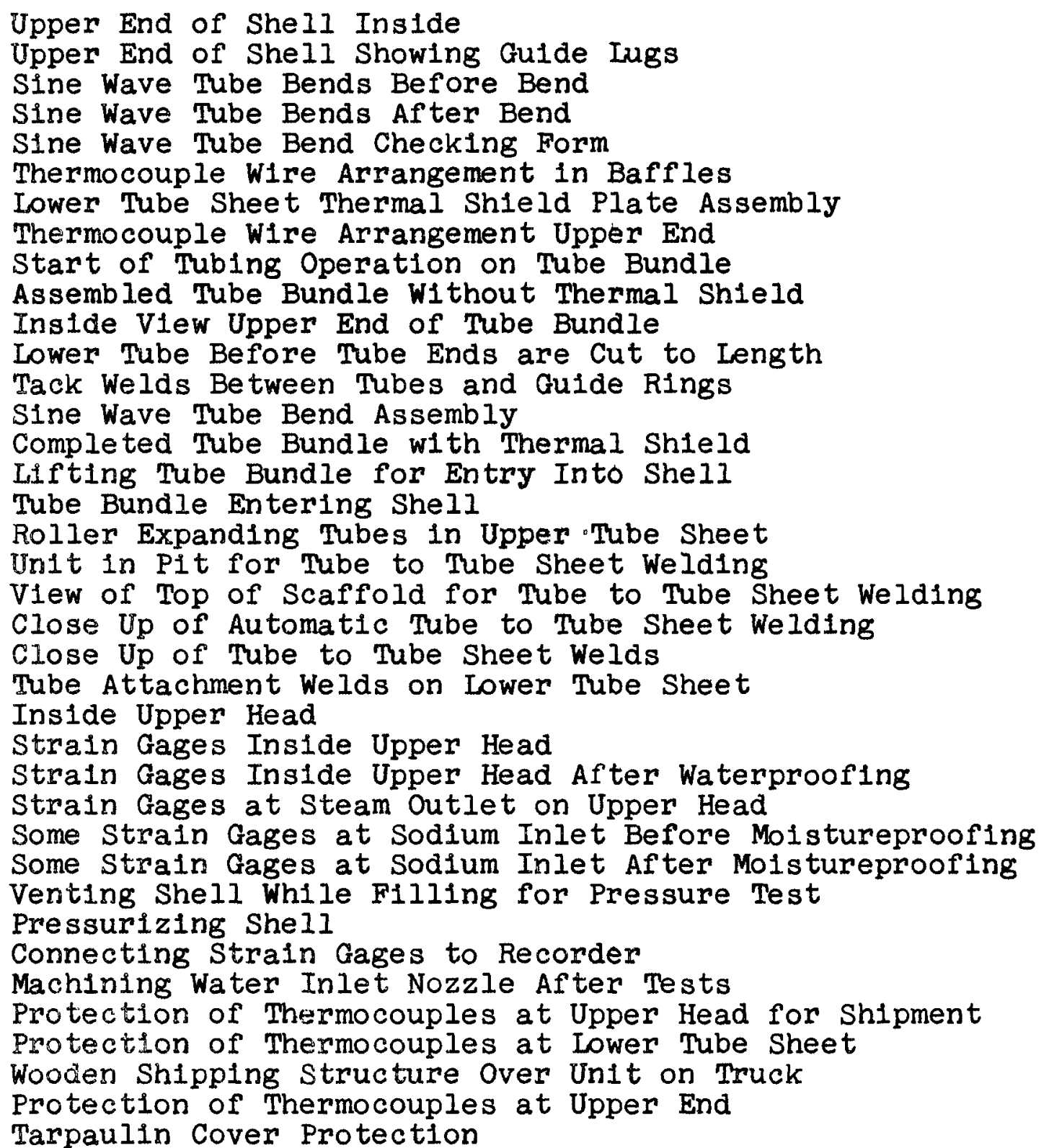 & \\
\hline
\end{tabular}




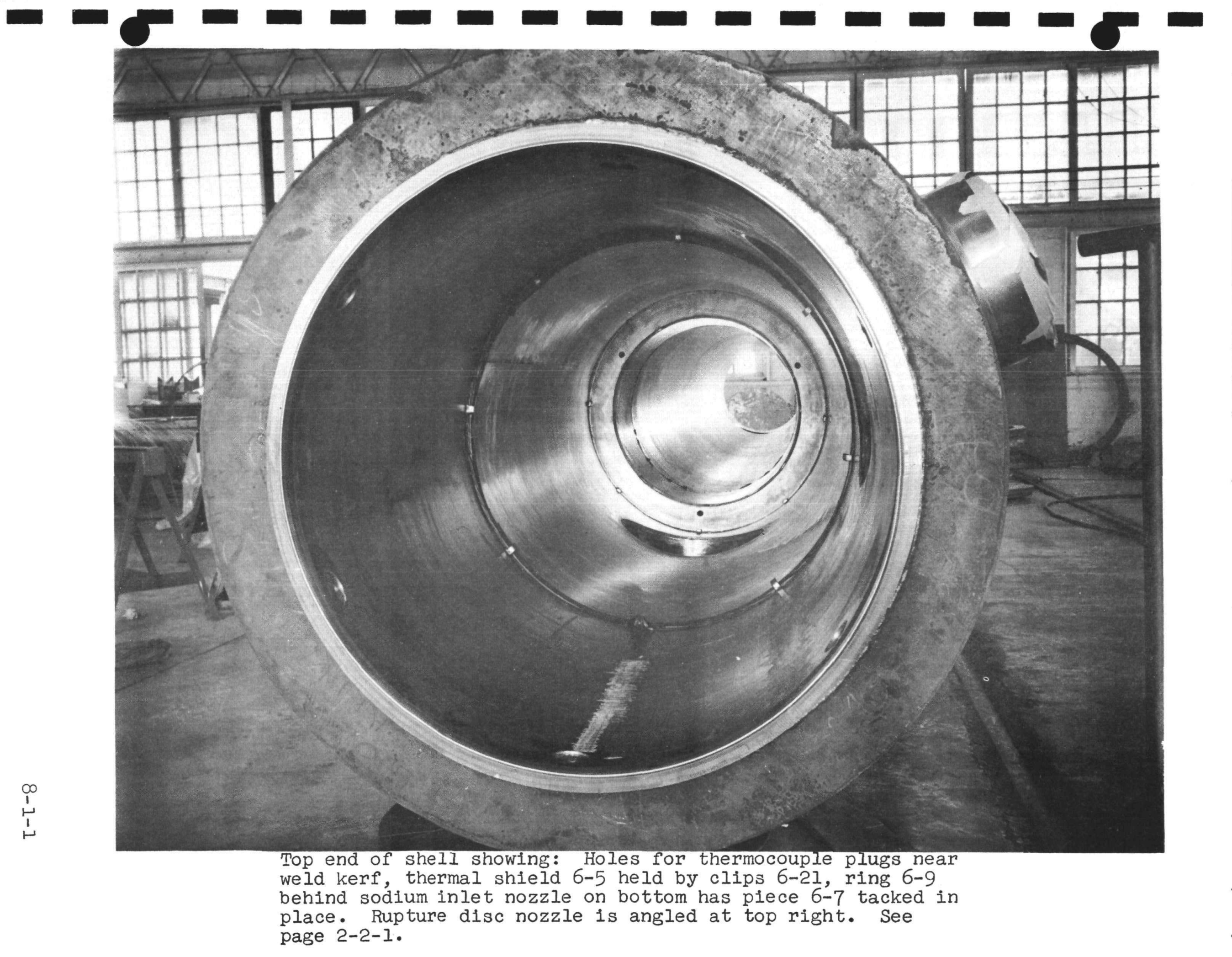




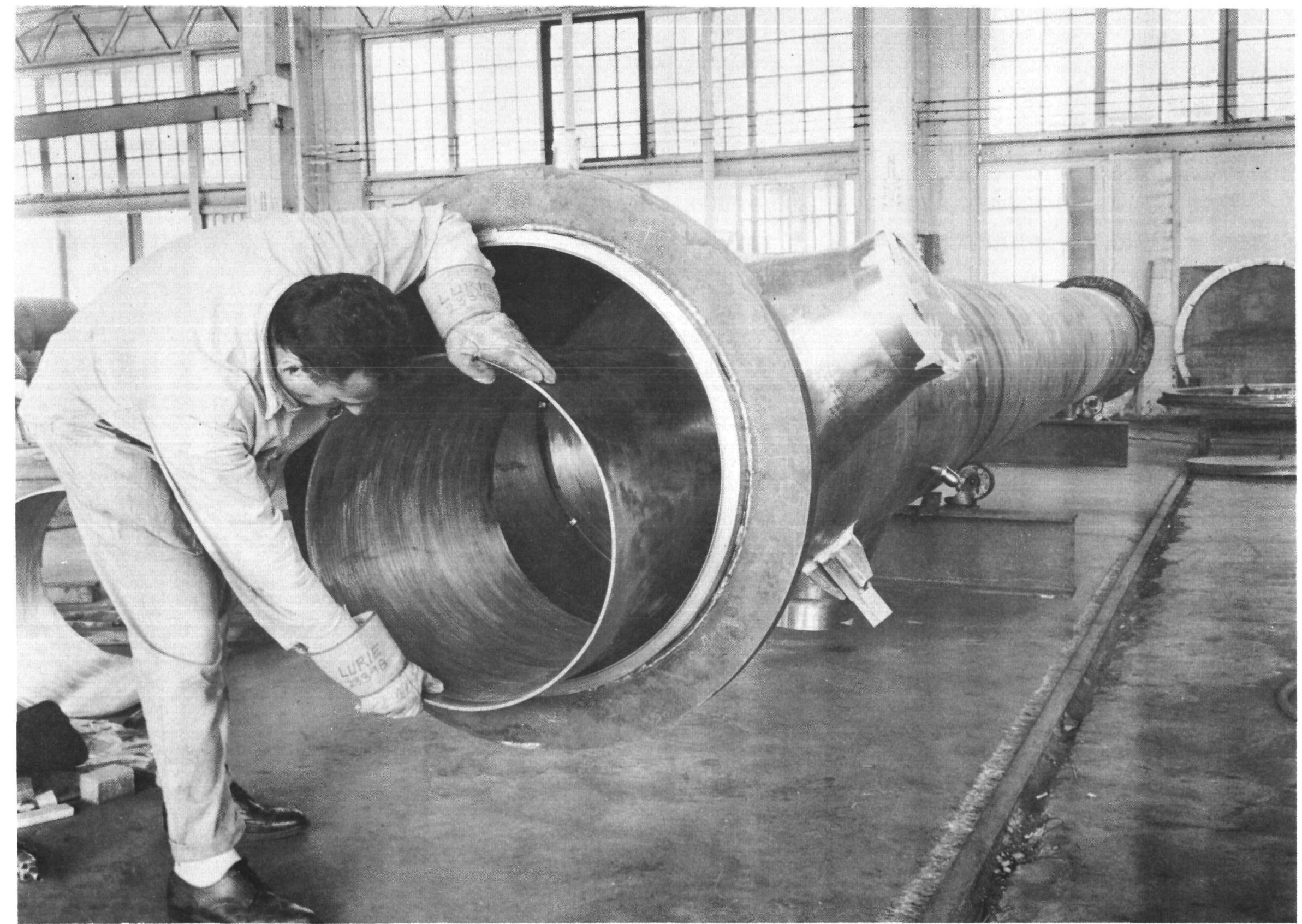

Entering piece 6-6 into shell. Carbon steel rings at each end are used to hold shell round. See page 2-1-1. 


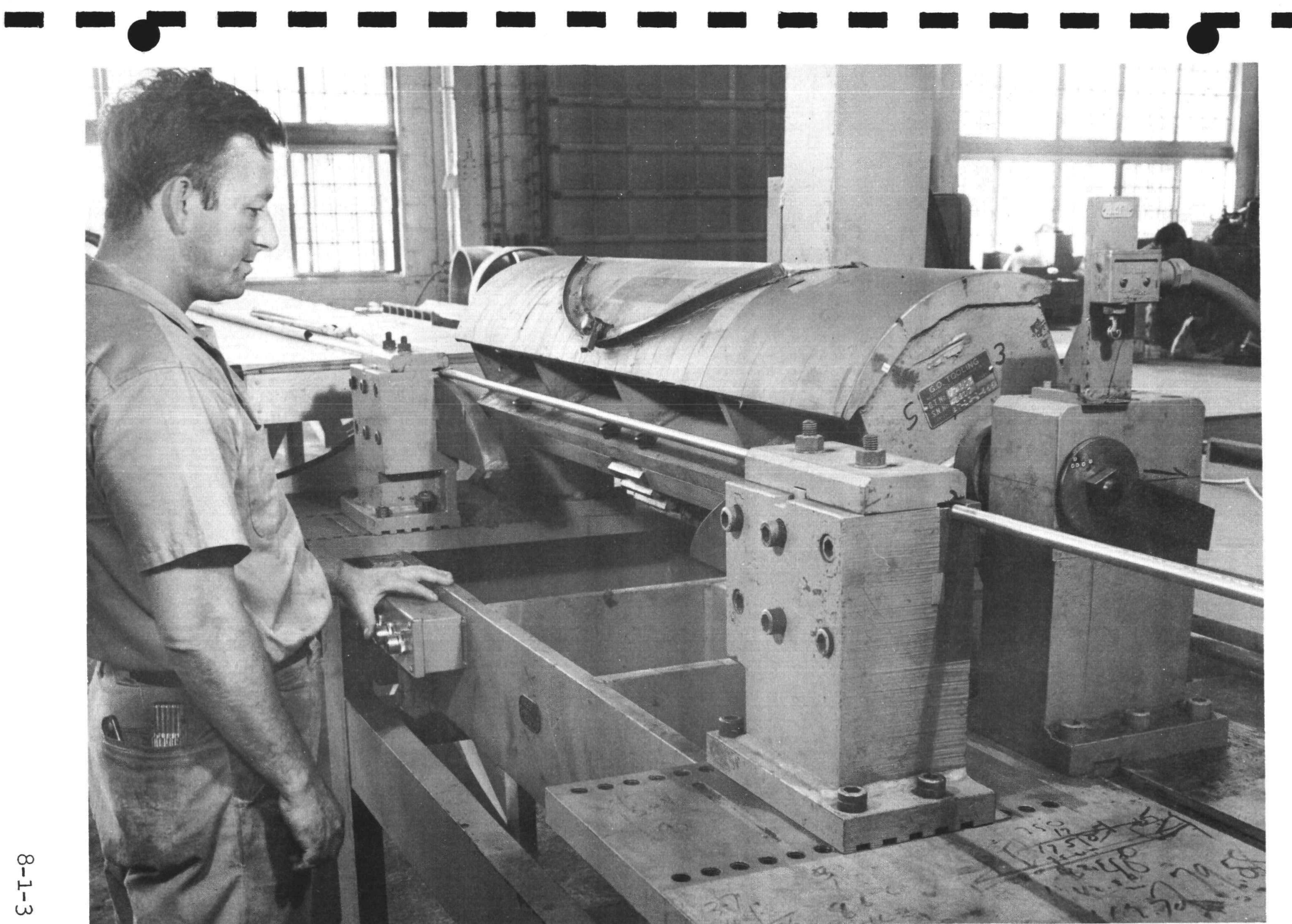

Sine wave tube bending machine with tube clamped in place ready to bend. 


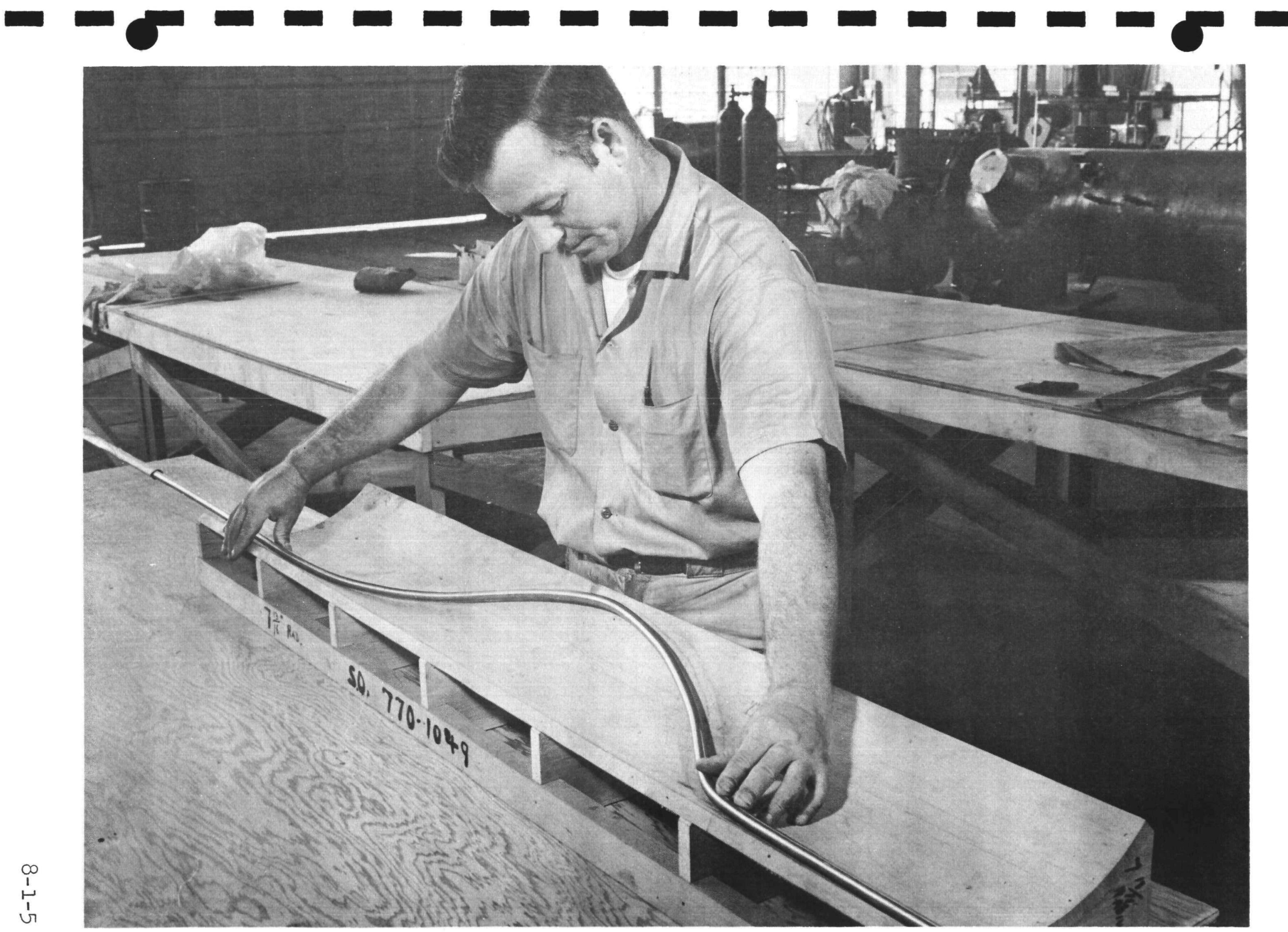

Sine wave tube bend checking form. 


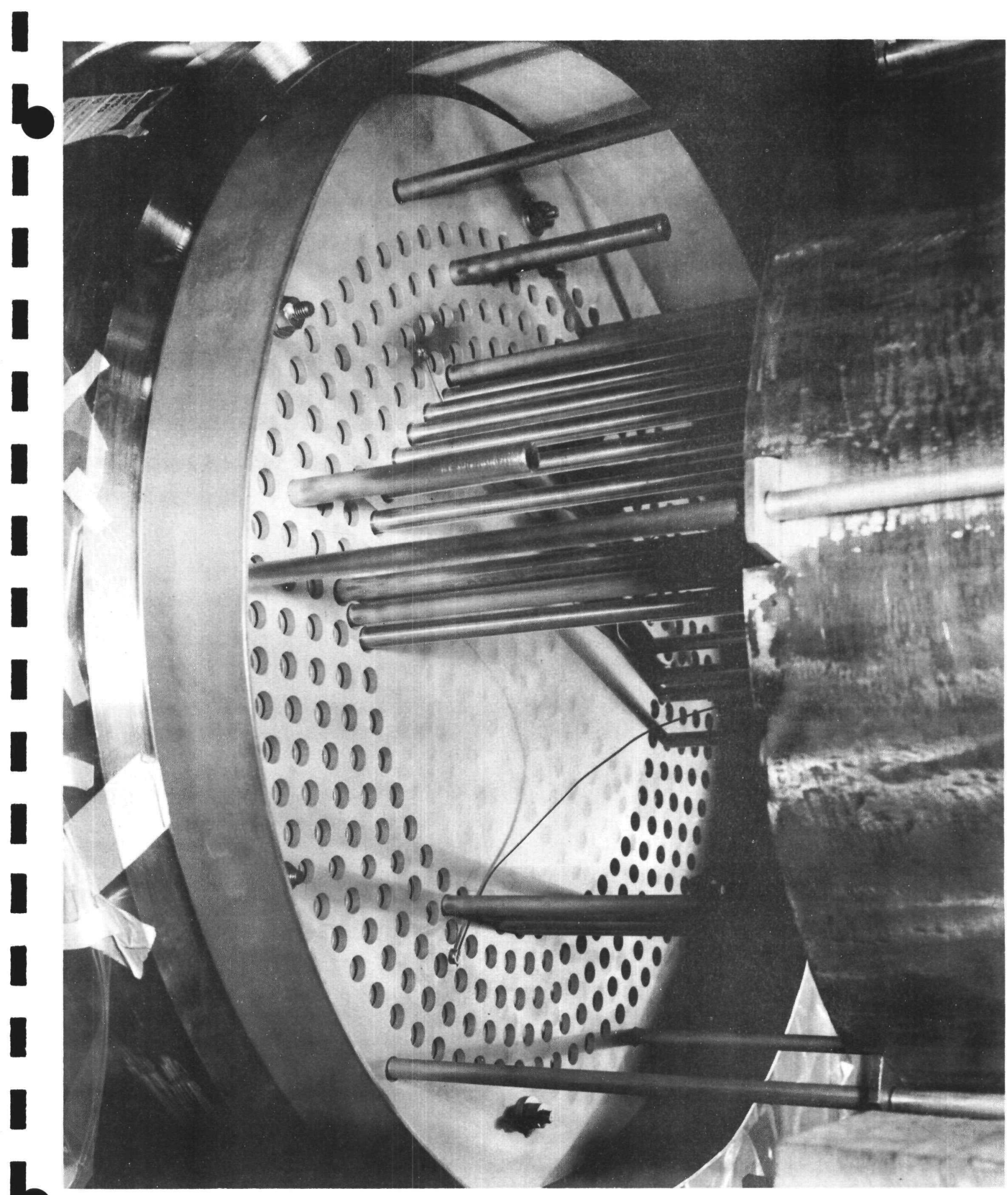

Thermocouples welded to thermal shield plate 6-12 inside thermal shield ring 6-1. Shroud 4-12 is on top. See page 3-1-2. 


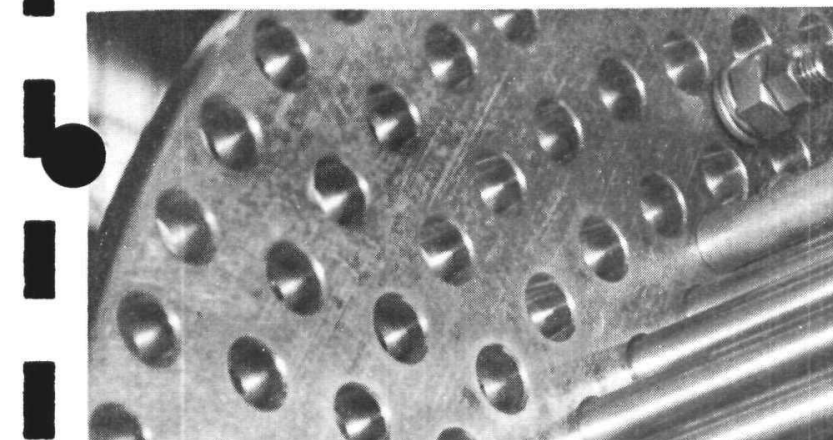

1009

1383

130

3.

$128=\frac{20}{20}$ - $\theta 0 \%$

- $\theta \theta \theta$

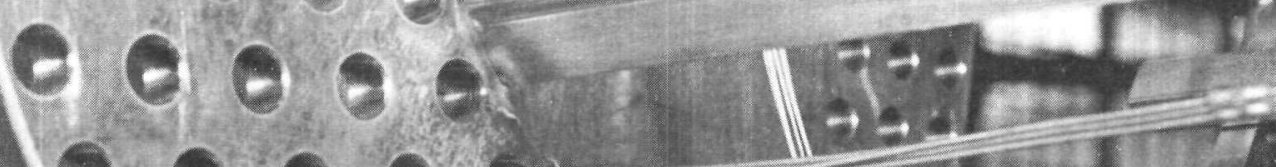

C $\theta \theta 0=$

c $\theta \theta \theta^{\circ}$ $\theta-\theta e \theta \operatorname{ercta}$

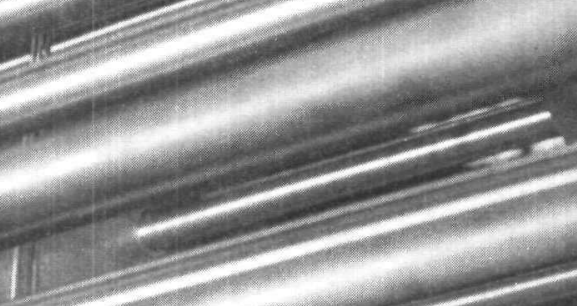




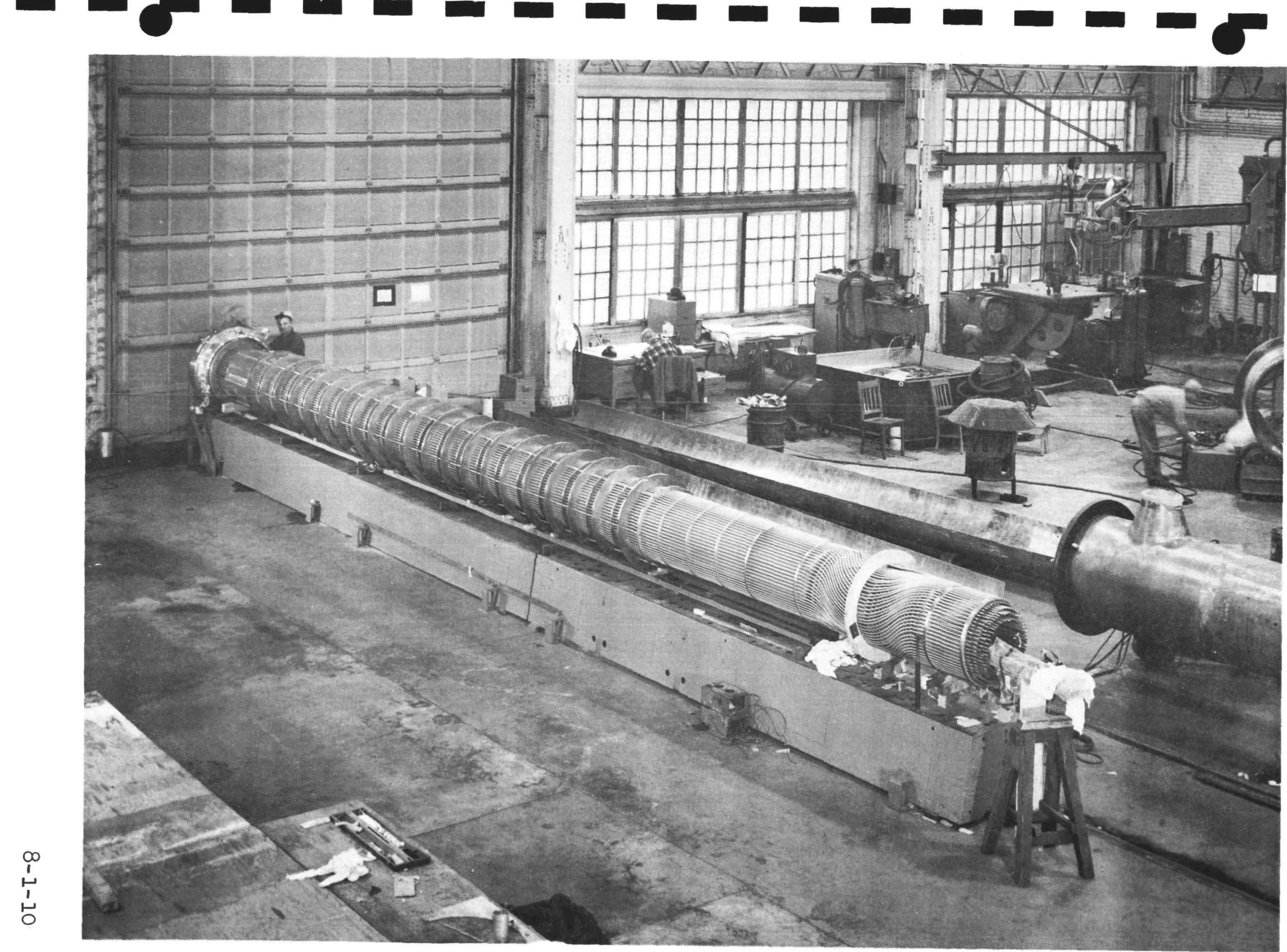

Assembled tube bundle before adding thermal shield piece 6-2. Wooden ring at sine wave bends is bend positioning fixture. 


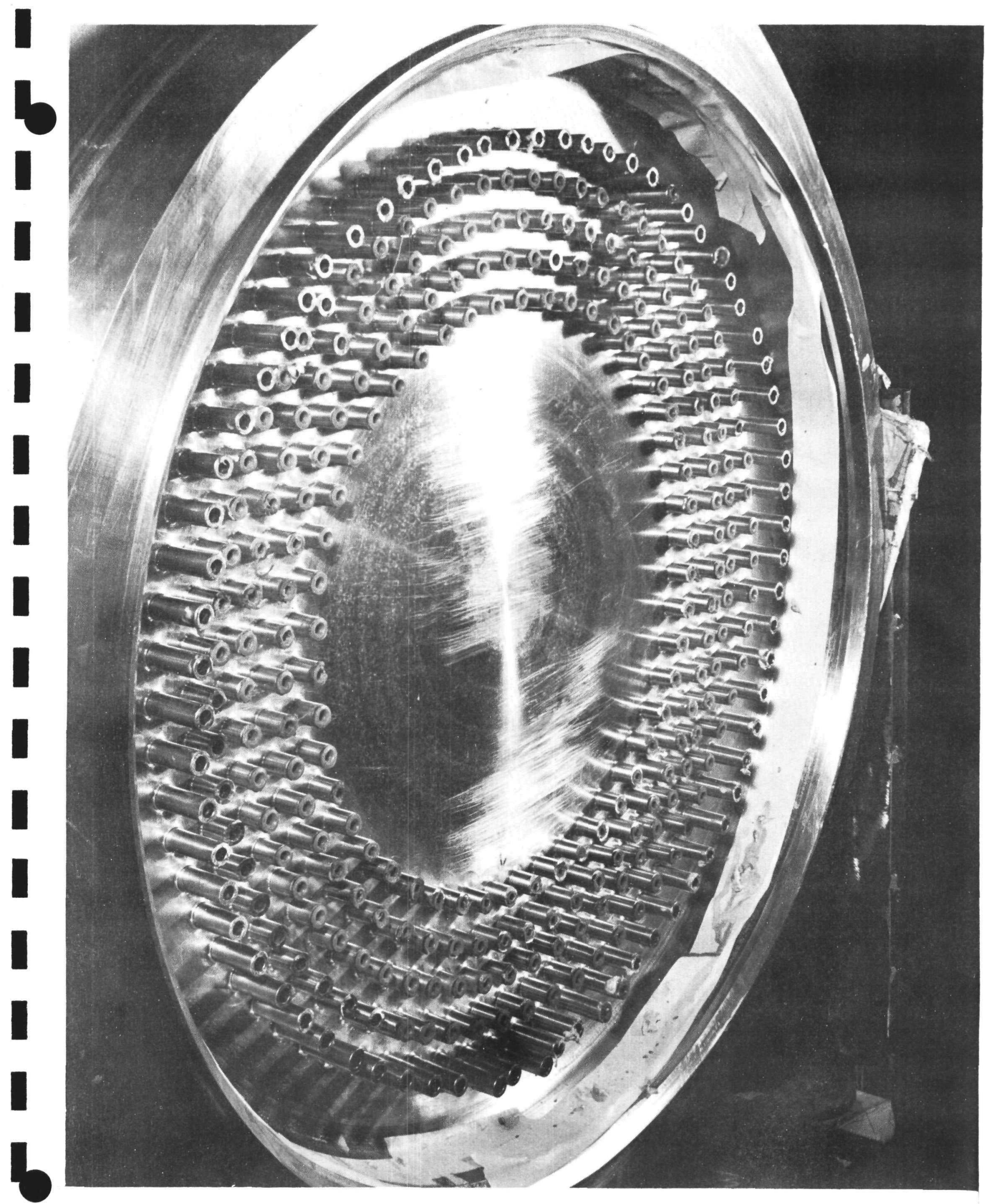

Lower tube sheet outer row of tubes not cut to length before. Plastic caps are inserted in inner rows for cleanliness. Grease on some outer rows is for roller expander lubrication. 


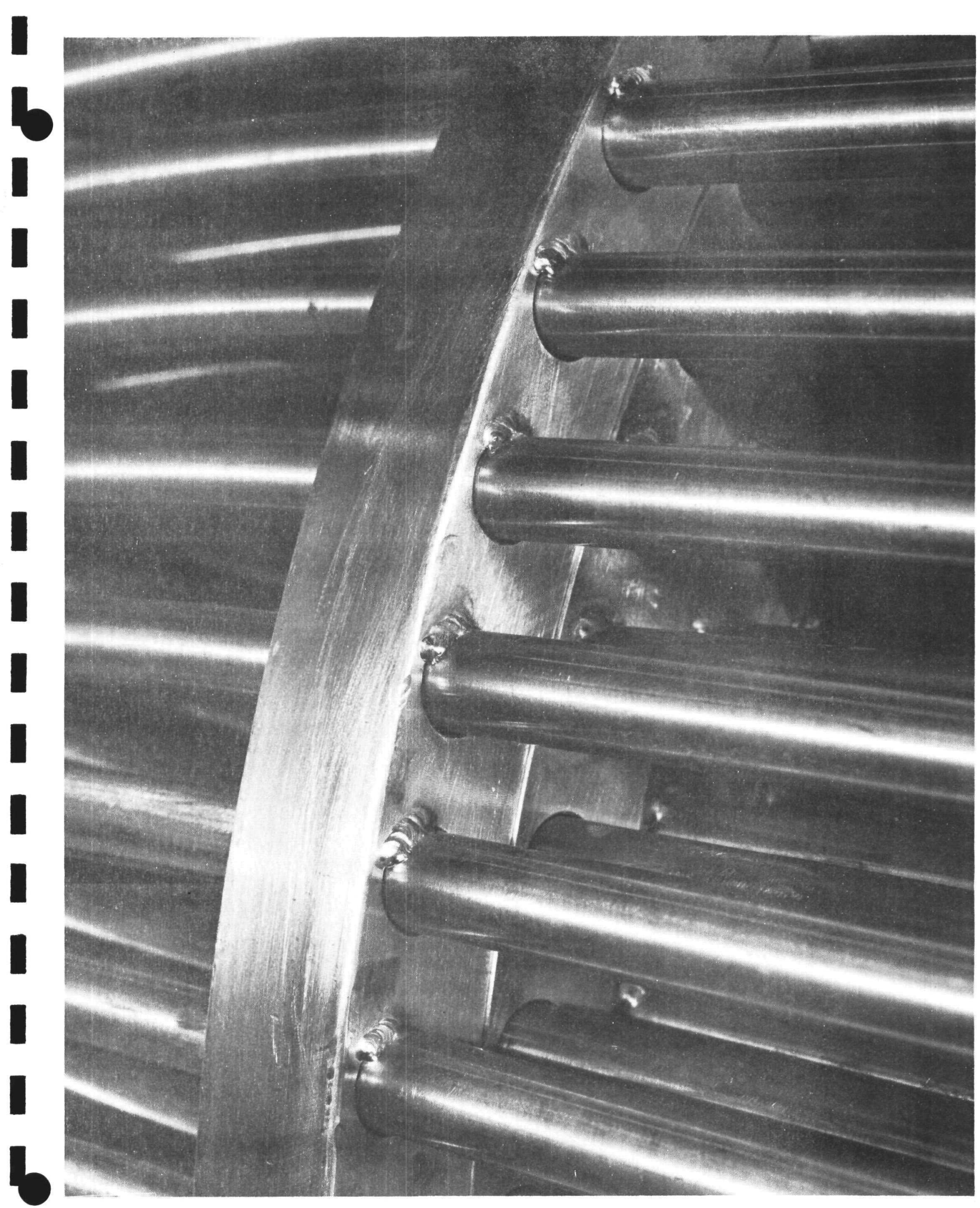

Close up of tack welds between outer row of tubes and guide ring piece 4-13E. 


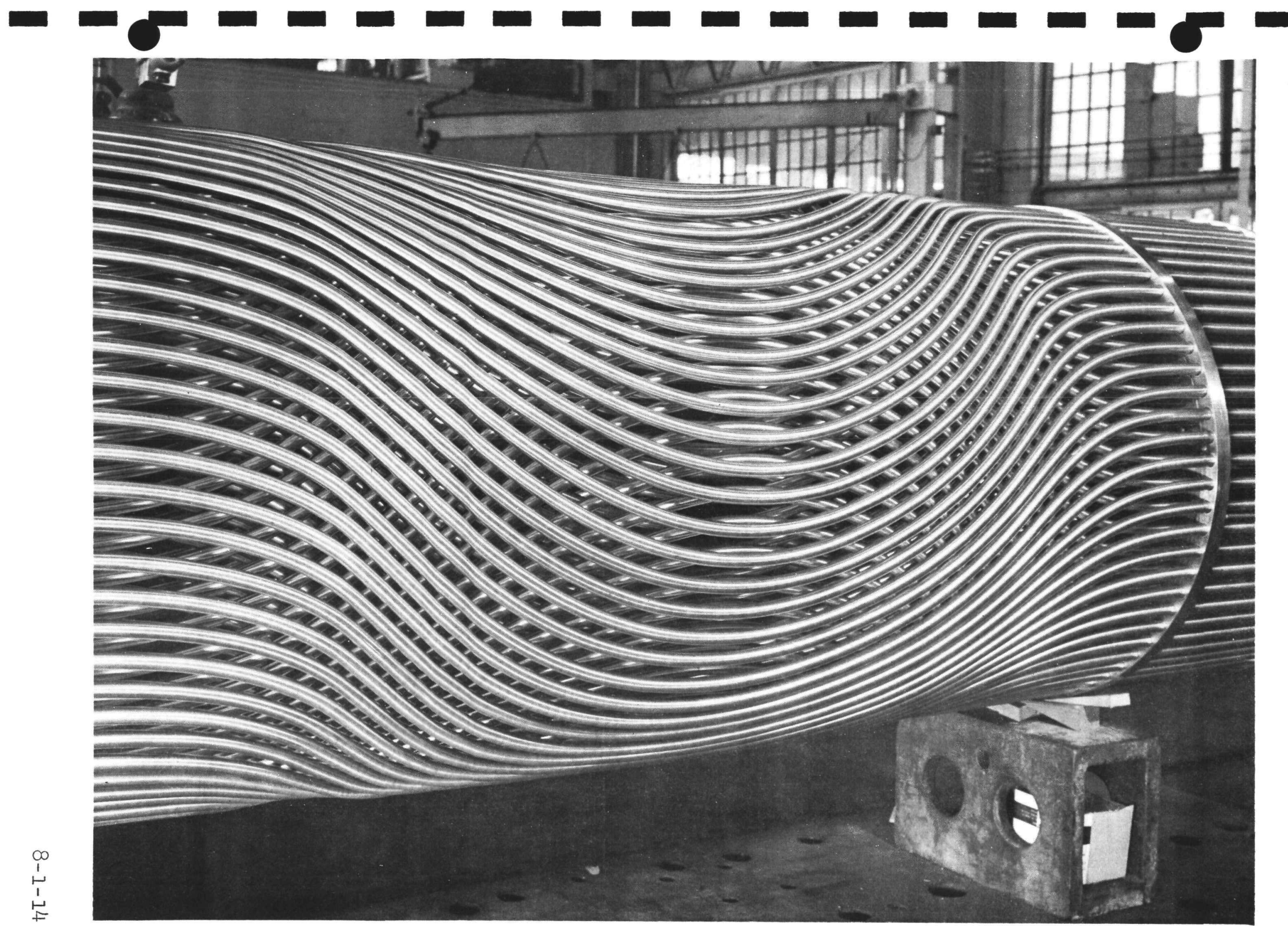

General view of assembled sine wave bends. The tube bends are alternated in direction of rotation from row to row. 


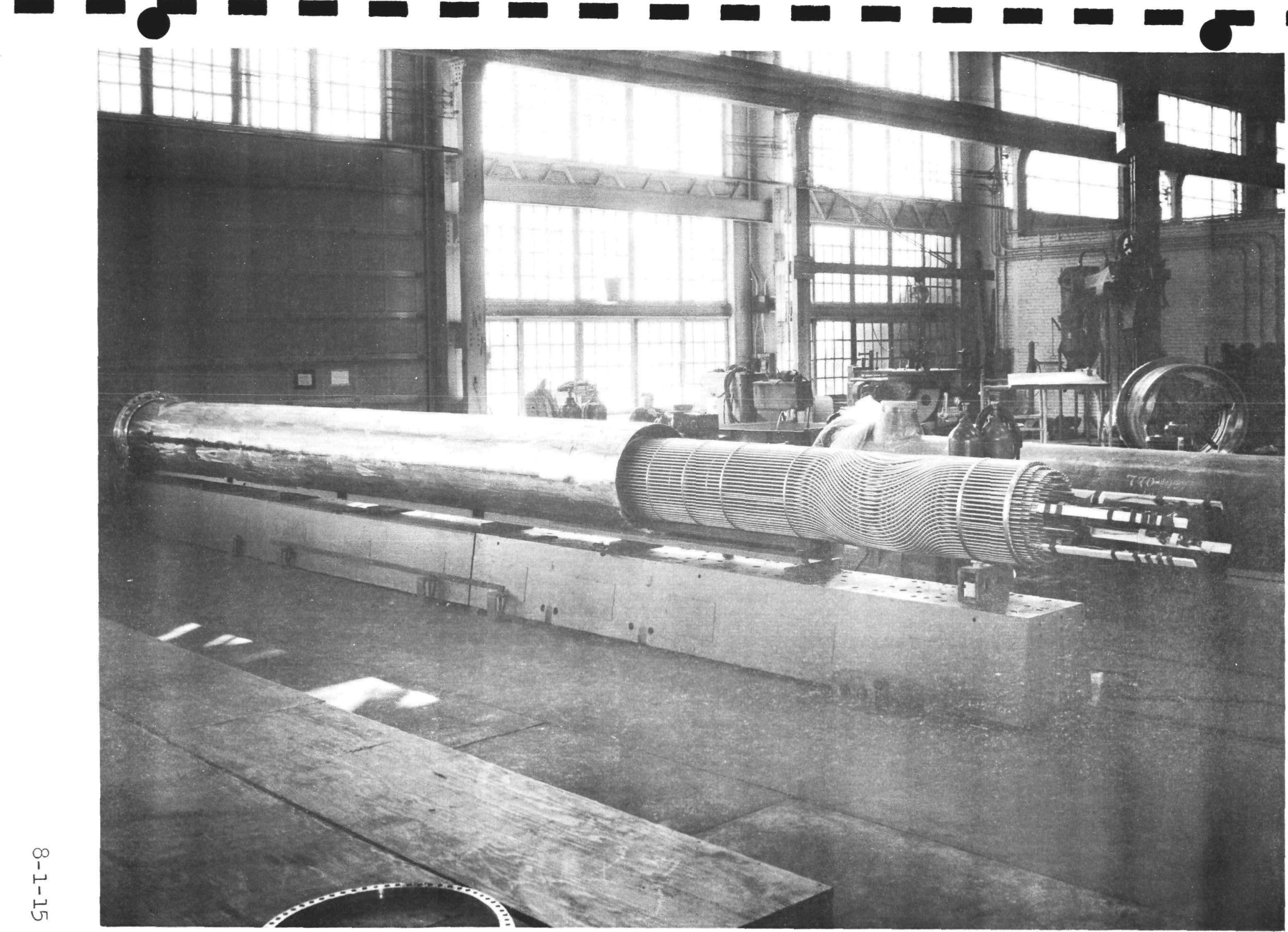

Completed tube bundle with thermal shield in place. Wooden supports at right carry thermocouple wires and plugs. 


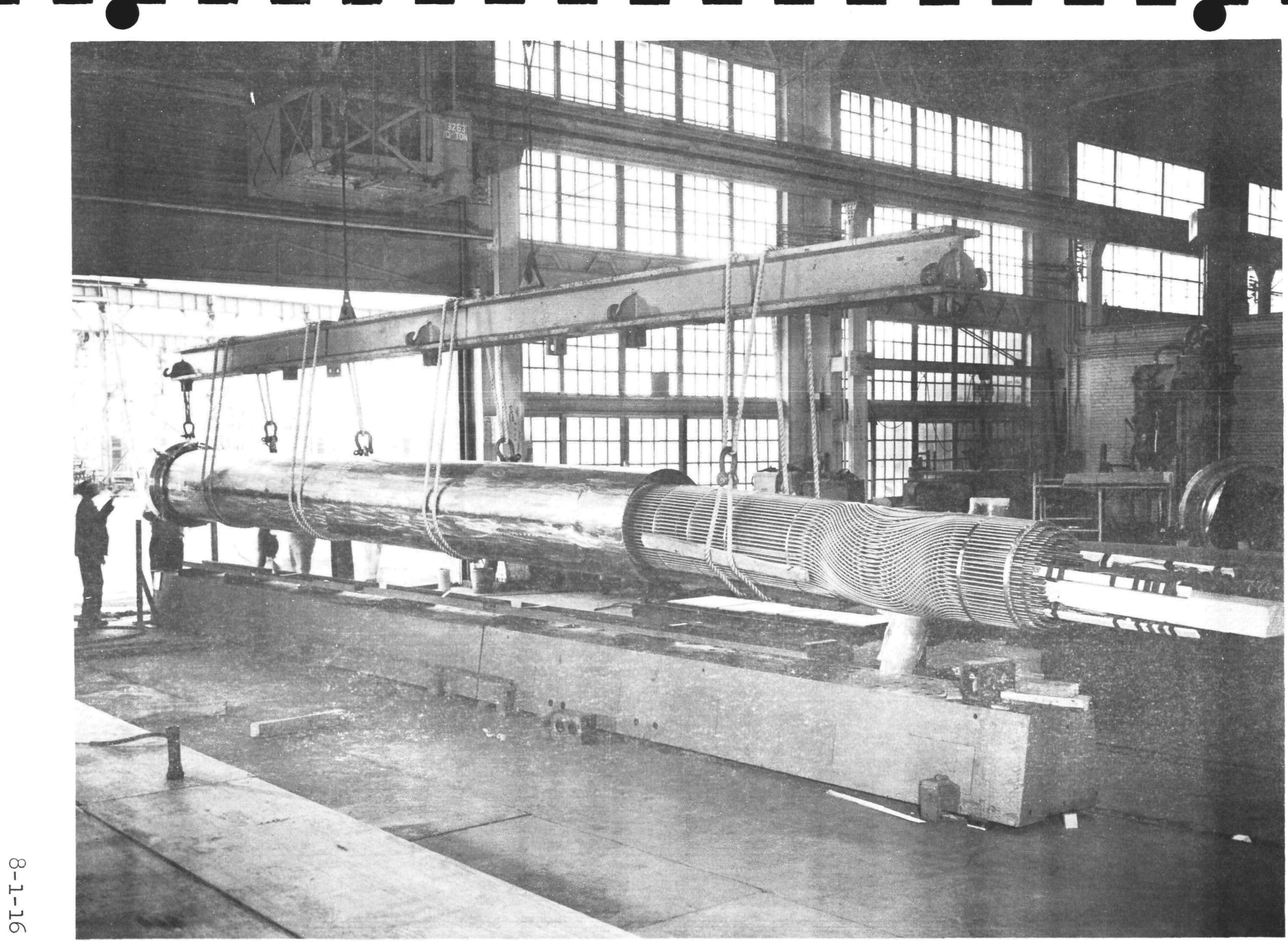

Lifting tube bundle for entry into shell. Note wooden supports over exposed baffles and taped wooden beam at right. See pages 3-1-4 and 3-2-1. 

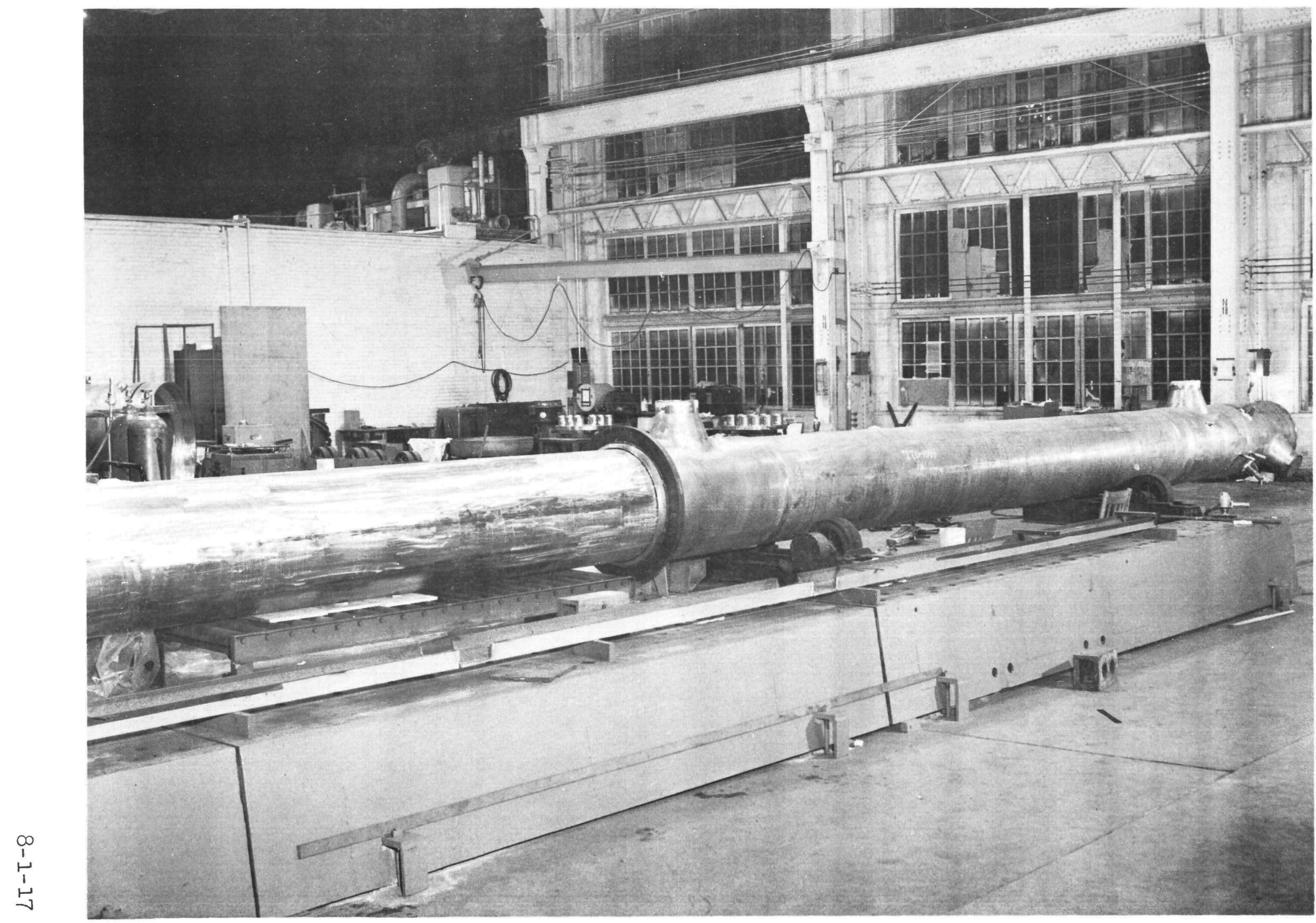

View of tube bundle entering shell with roller bed support under bundle. See page 3-2-1. 


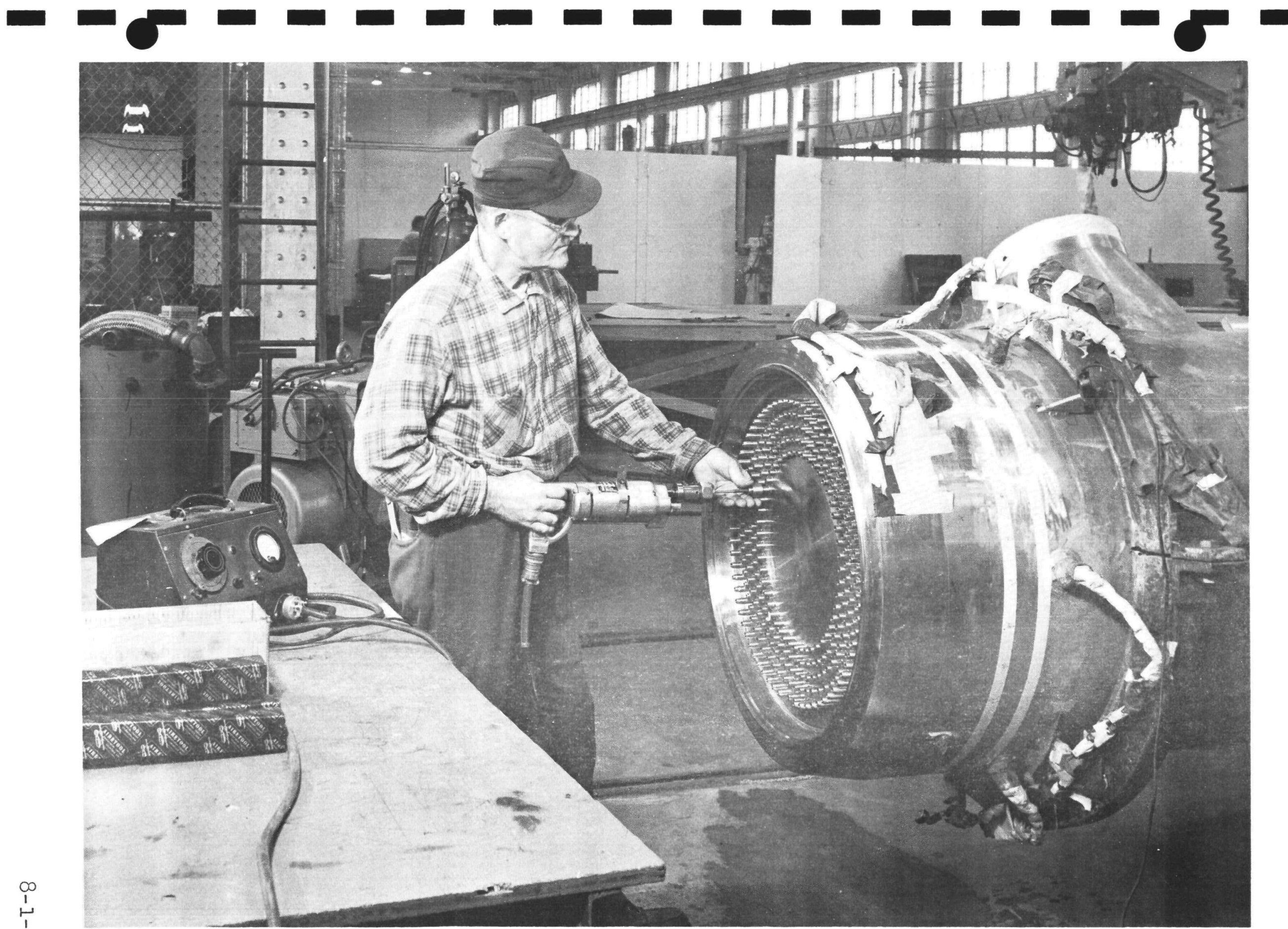

$\stackrel{\leftrightarrow}{\infty}$

Roller expanding tubes into upper tube sheet with electronically controlled torque expander. Thermocouple wires are taped to tube sheet assembly guide ring. See page 3-3-1 and 3-5-1. 


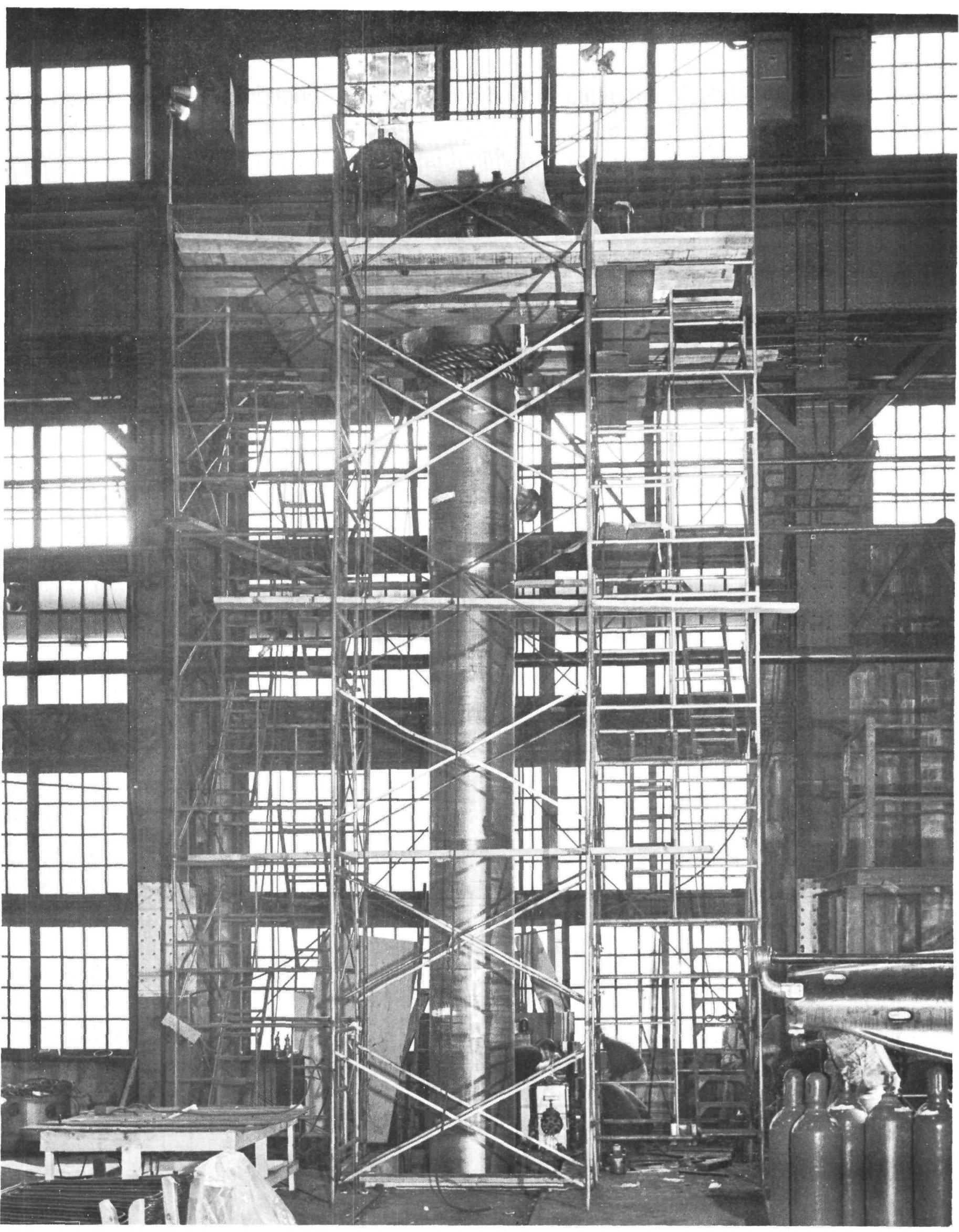

Unit vertical in pit with scaffolding to upper tube sheet for tube to tube sheet welding. Large ring at top is fixture for holding welding gun. 


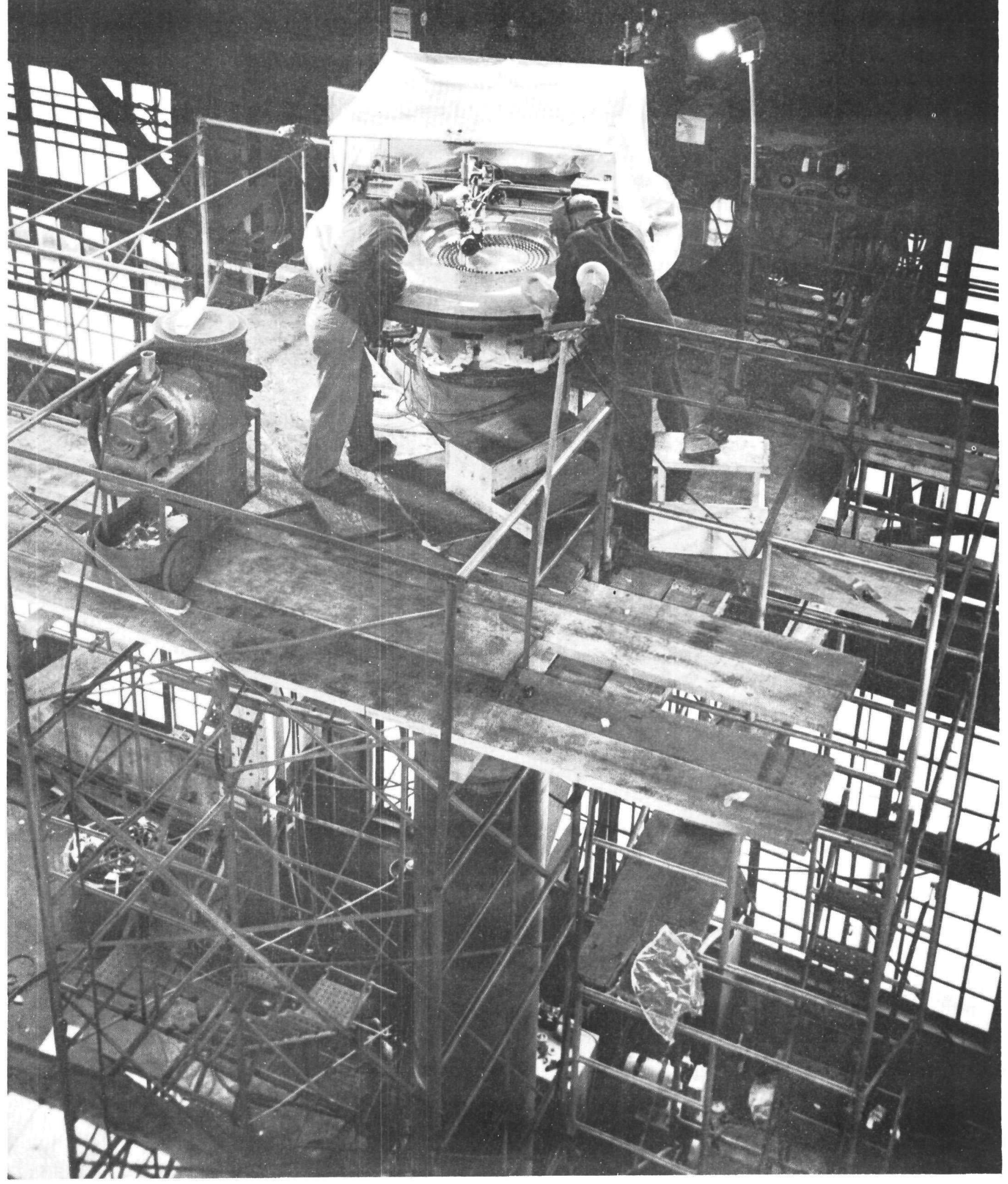

View of top with welding of tube to tube sheet attachments with automatic T.I.G. with inconel wire feed. Plastic housing keeps drafts from disturbing inert gas weld shield. 


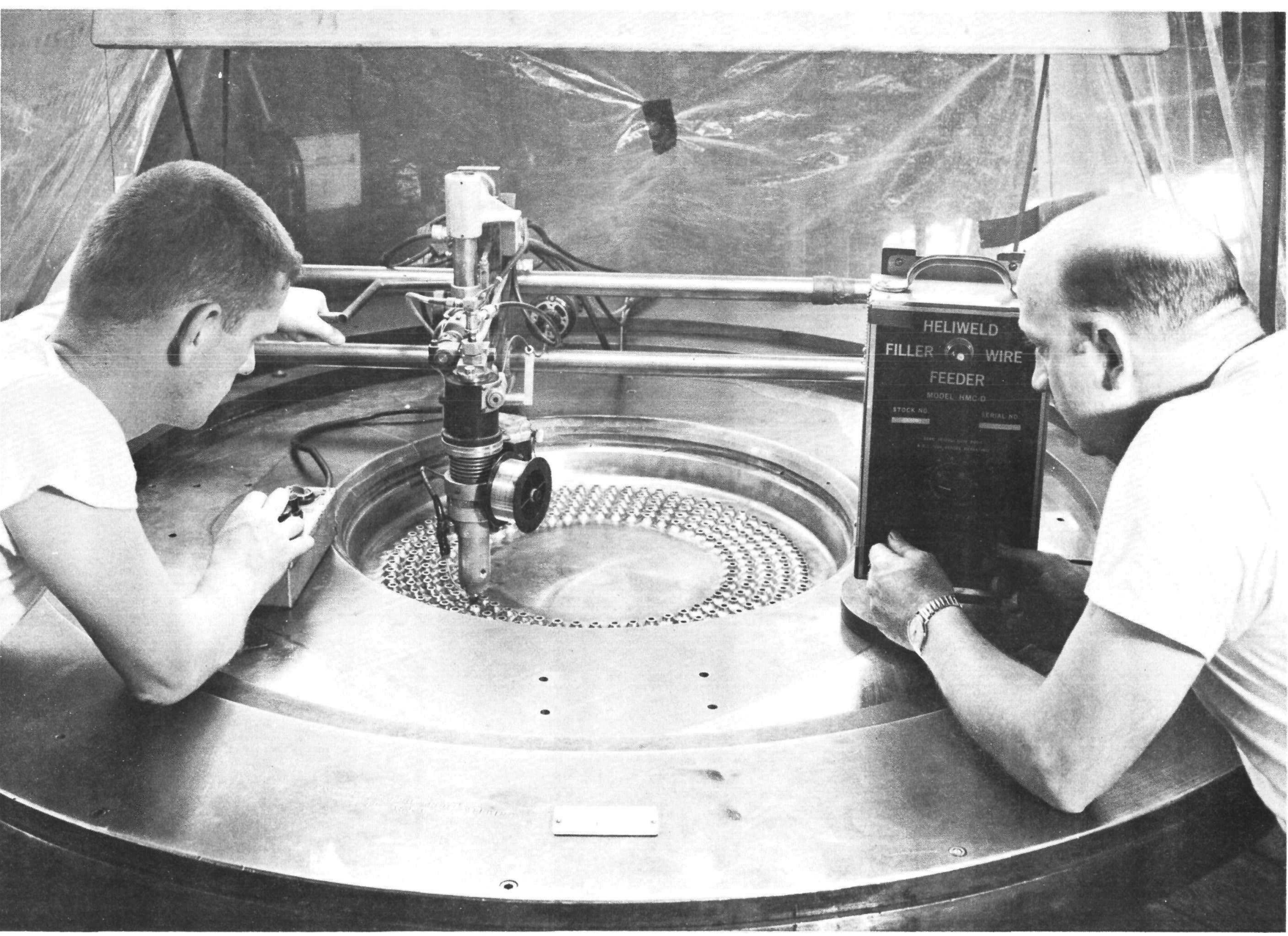

Close up of automatic T.I.G. With wire feed tube to tube sheet welding gun supported on special ring fixture as upper tube joints are welded. 


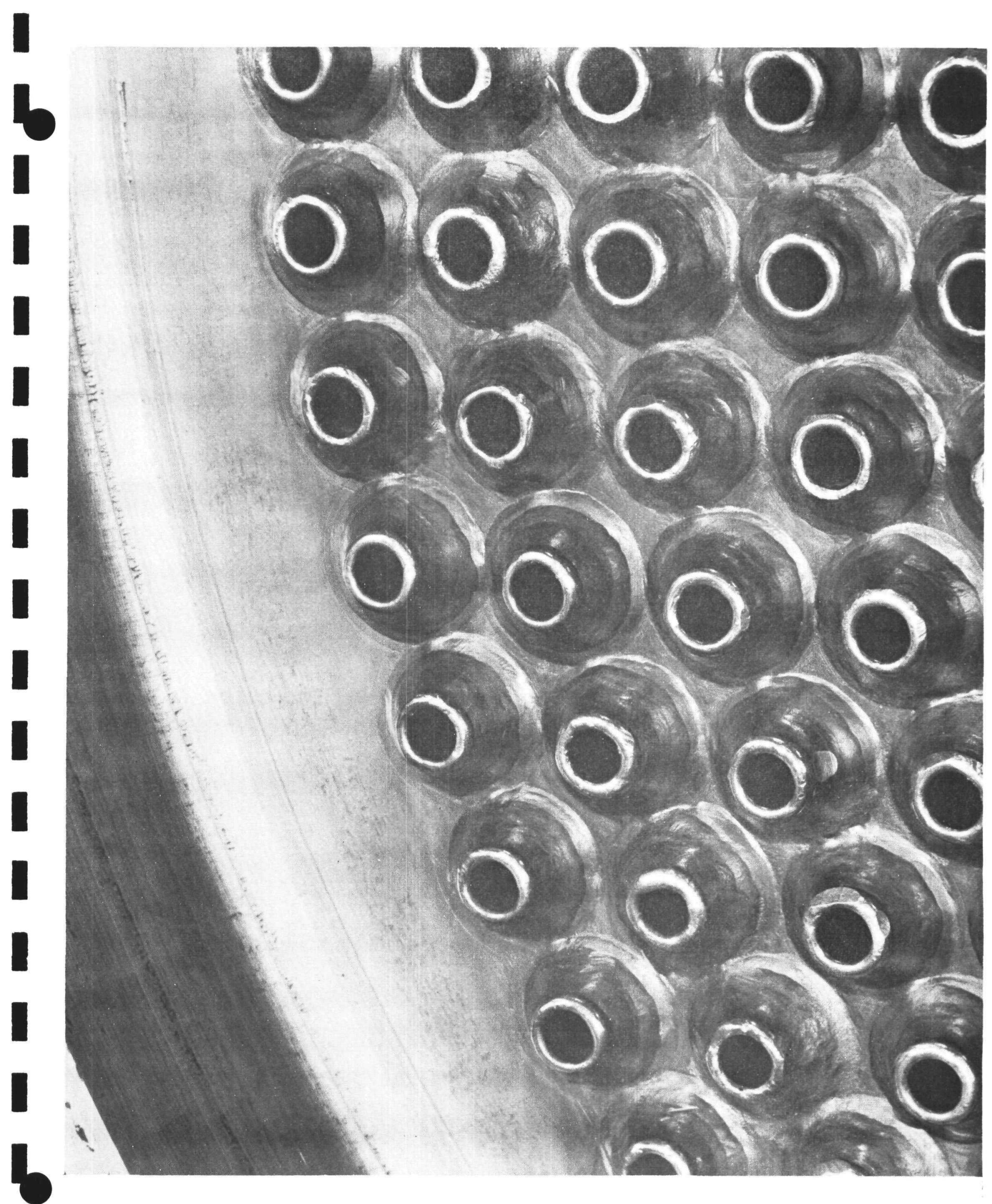

Close up of tube to tube sheet welds. 


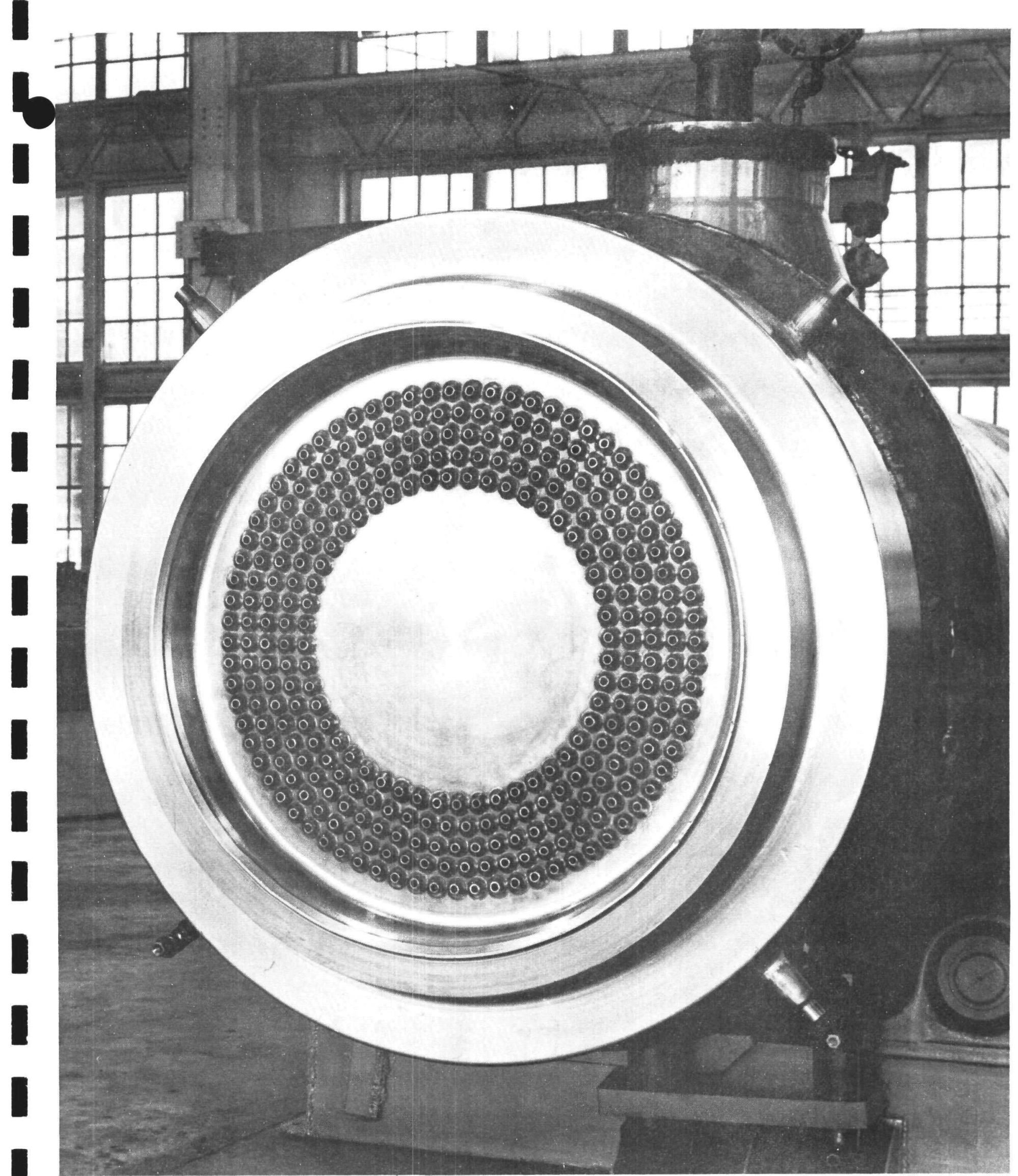

View of lower tube sheet after tube to tube sheet welding. 


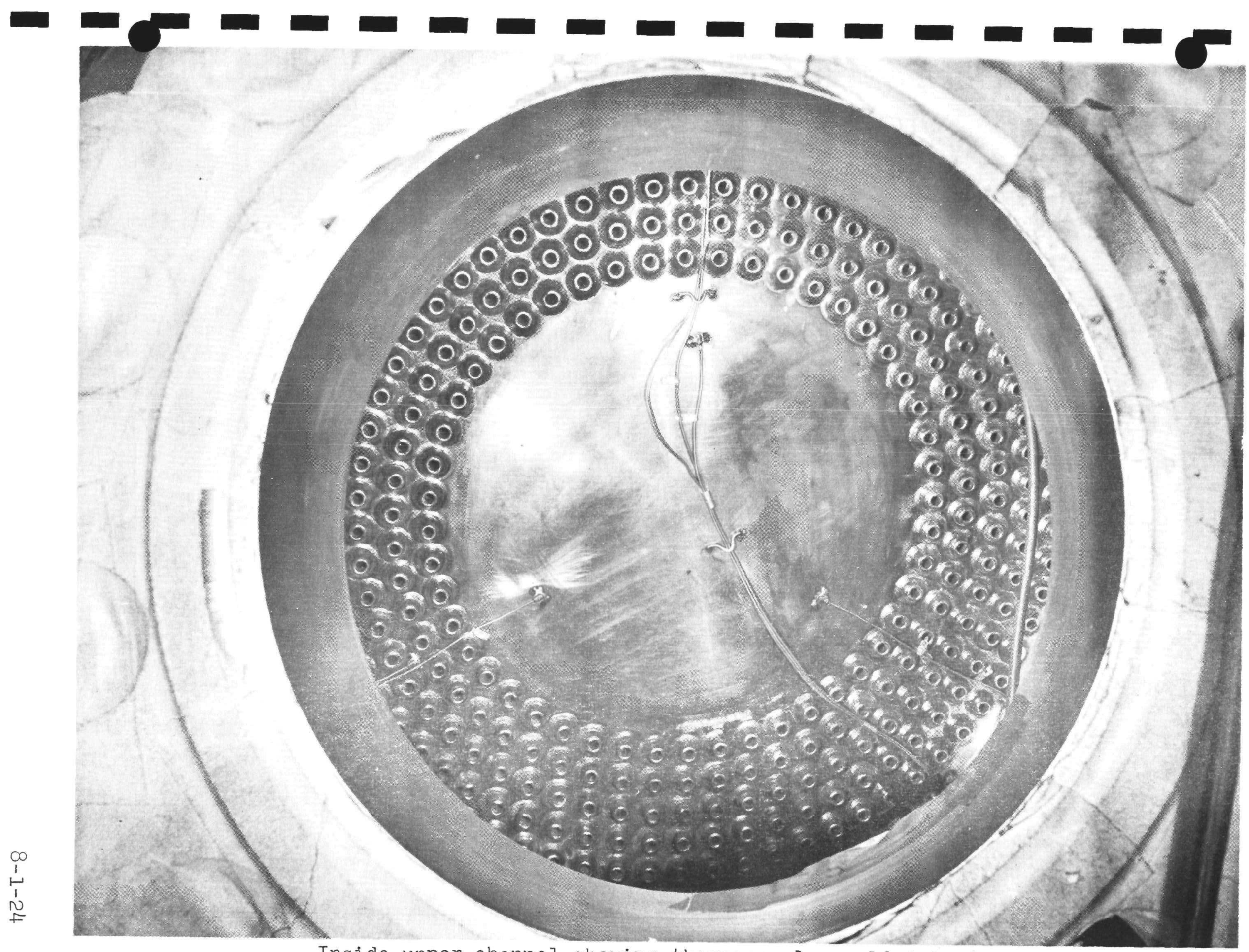

Inside upper channel showing thermocouples welded to face of tube sheet. 


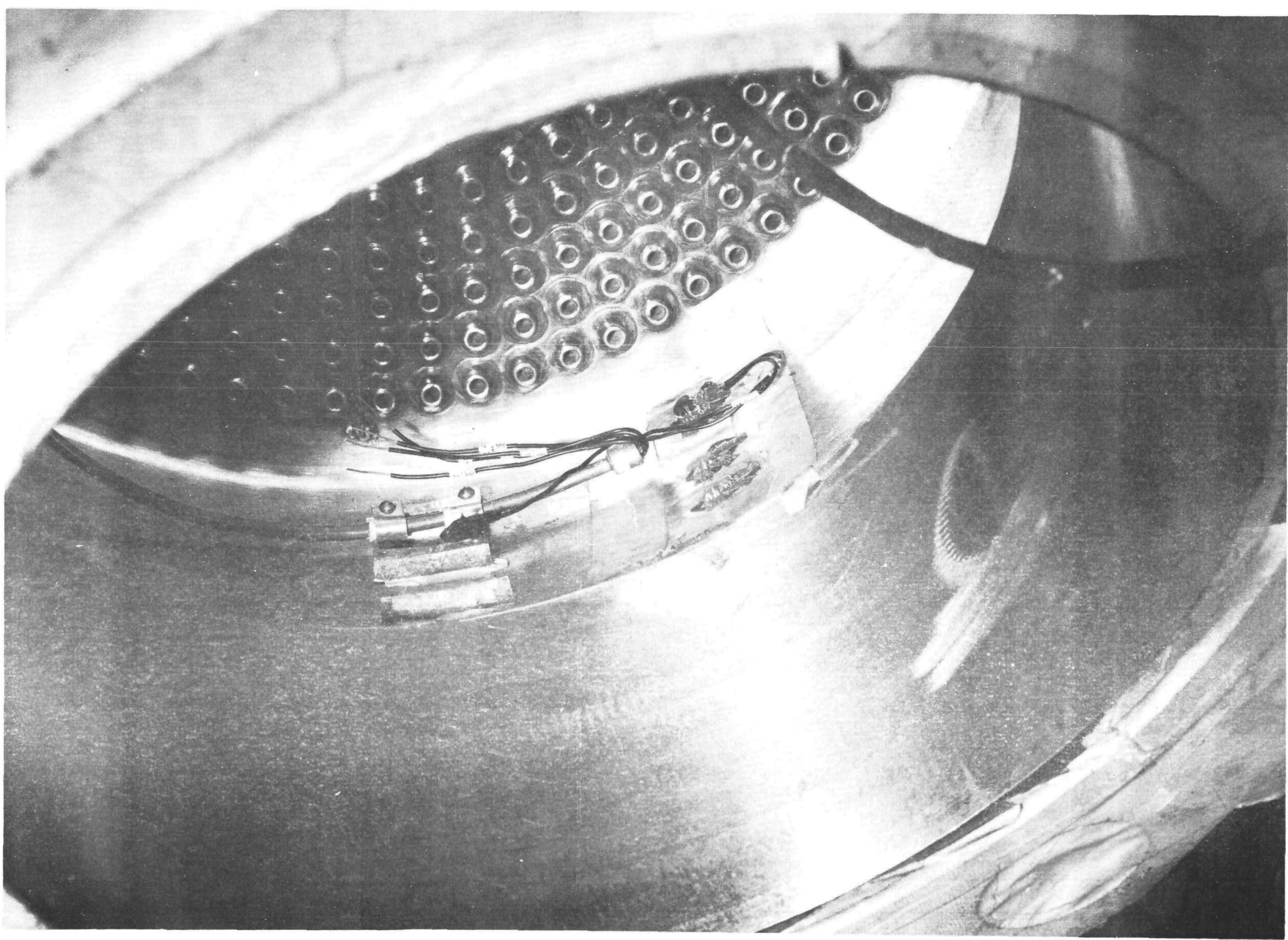

Strain gages inside upper head before waterproofing showing one lead partially connected. 


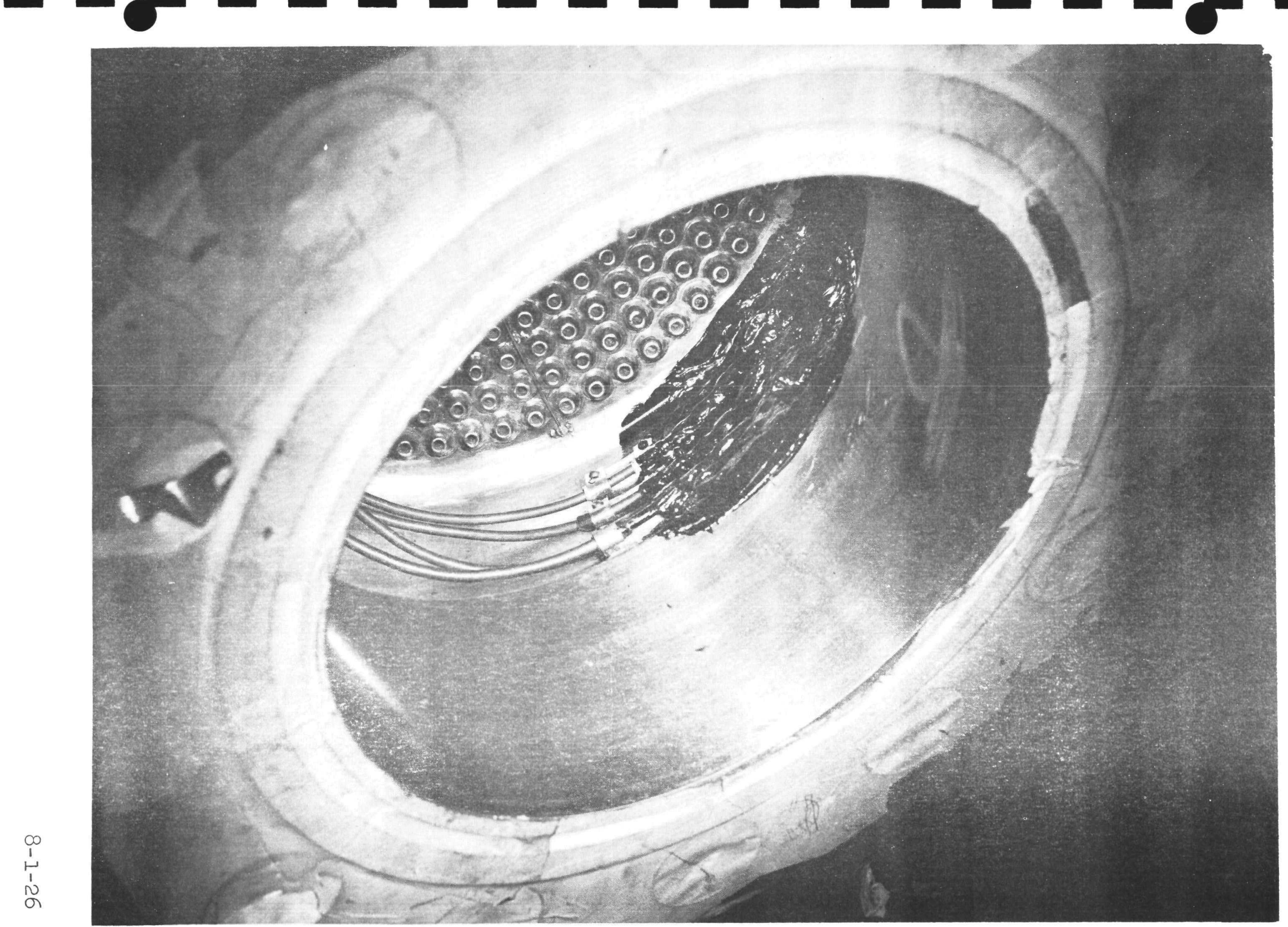

Strain gages inside upper head after leads were connected and all is waterproofed. 


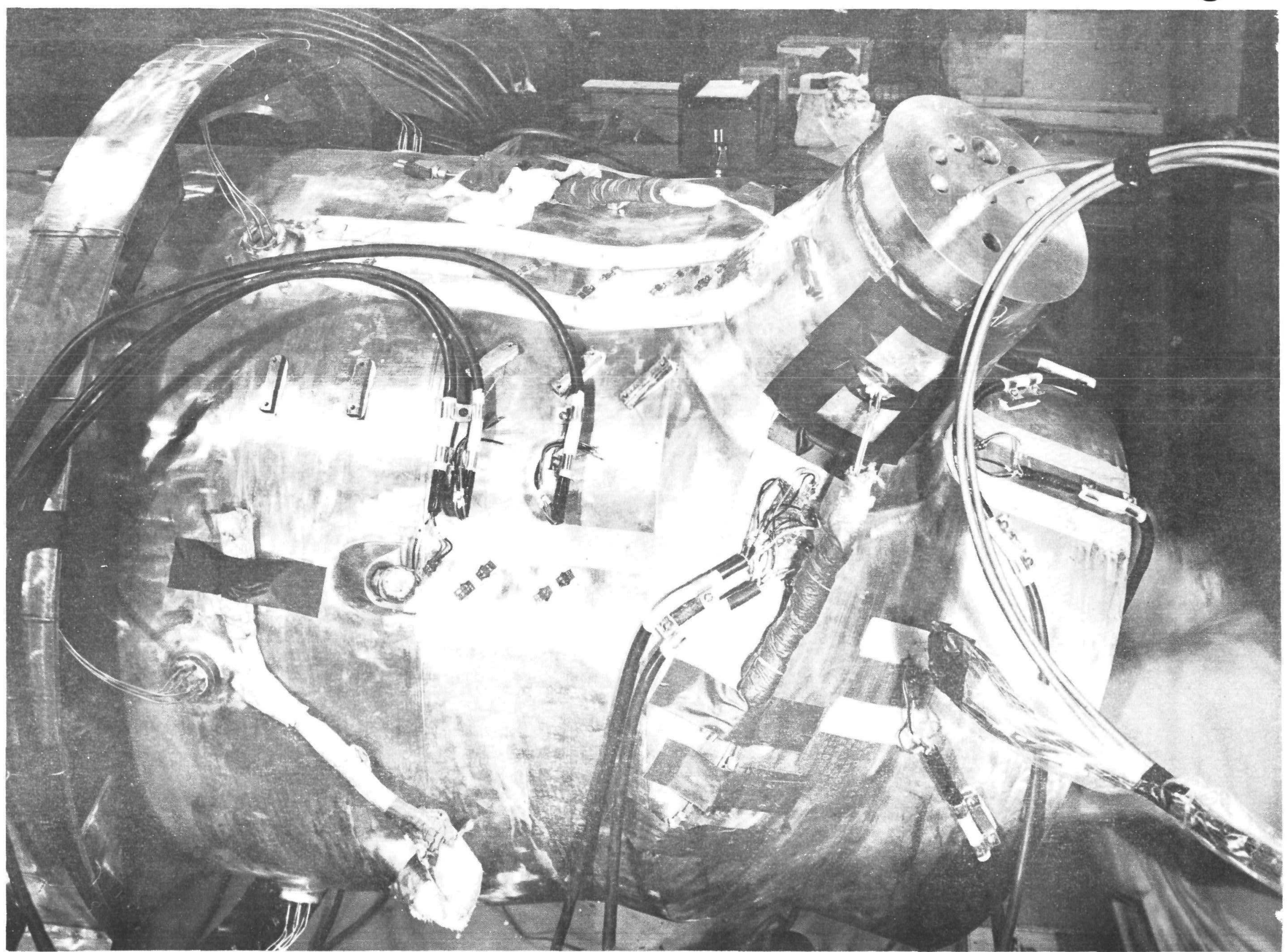

Strain gages around upper head and steam outlet nozzle partially connected before moisture proofing. 


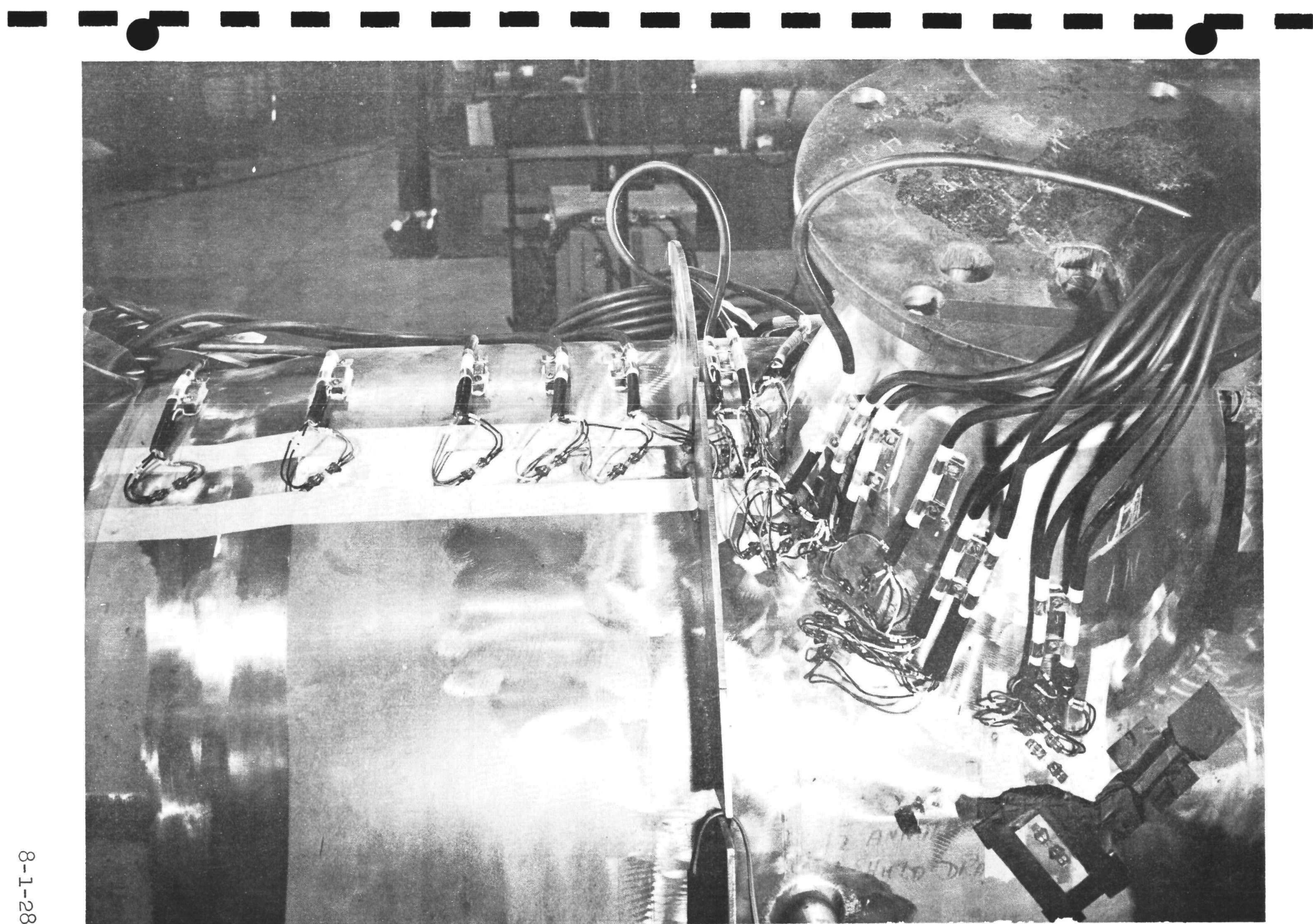

Some of strain gages around sodium inlet nozzle before moisture proofing. 


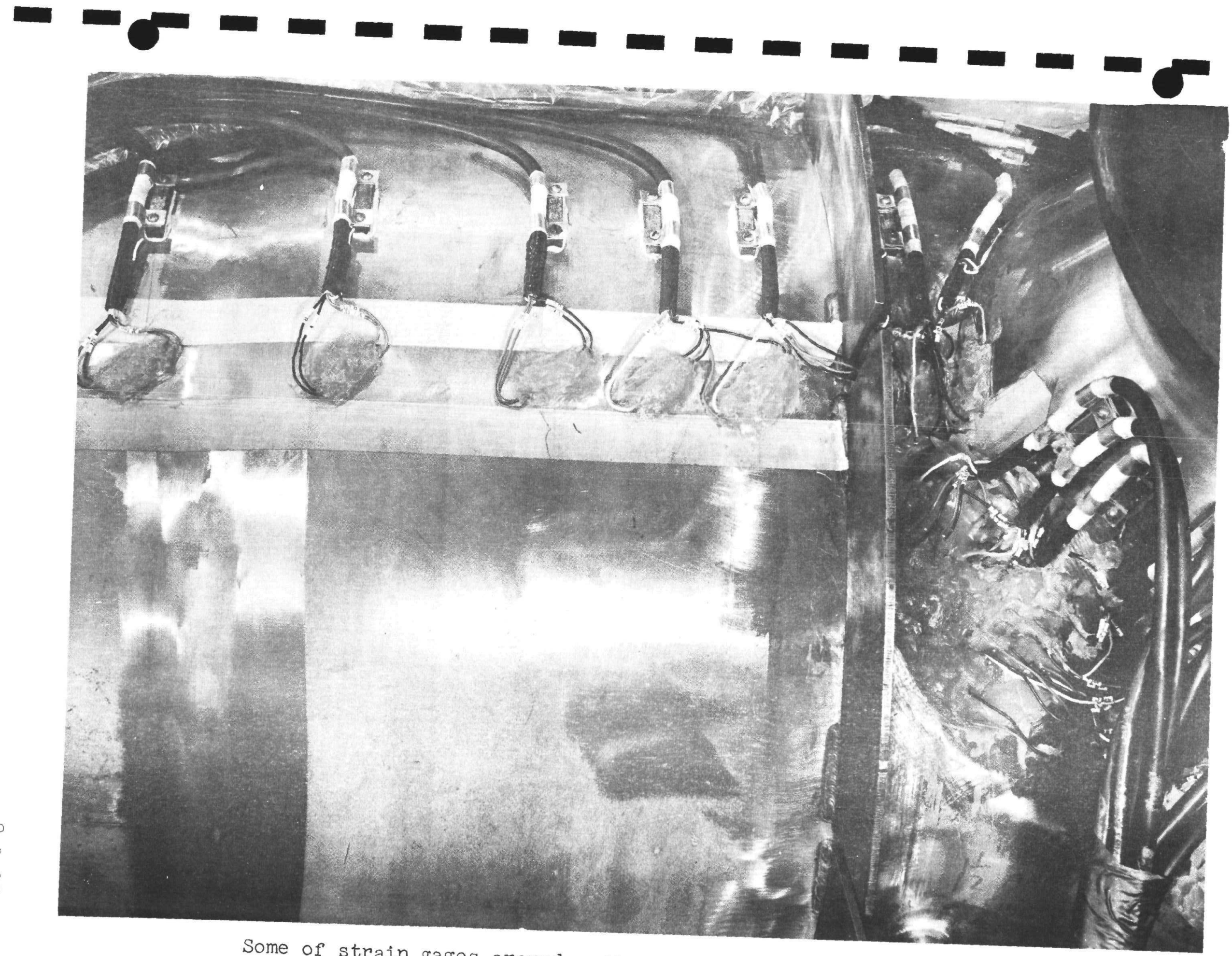

waterproofing. 


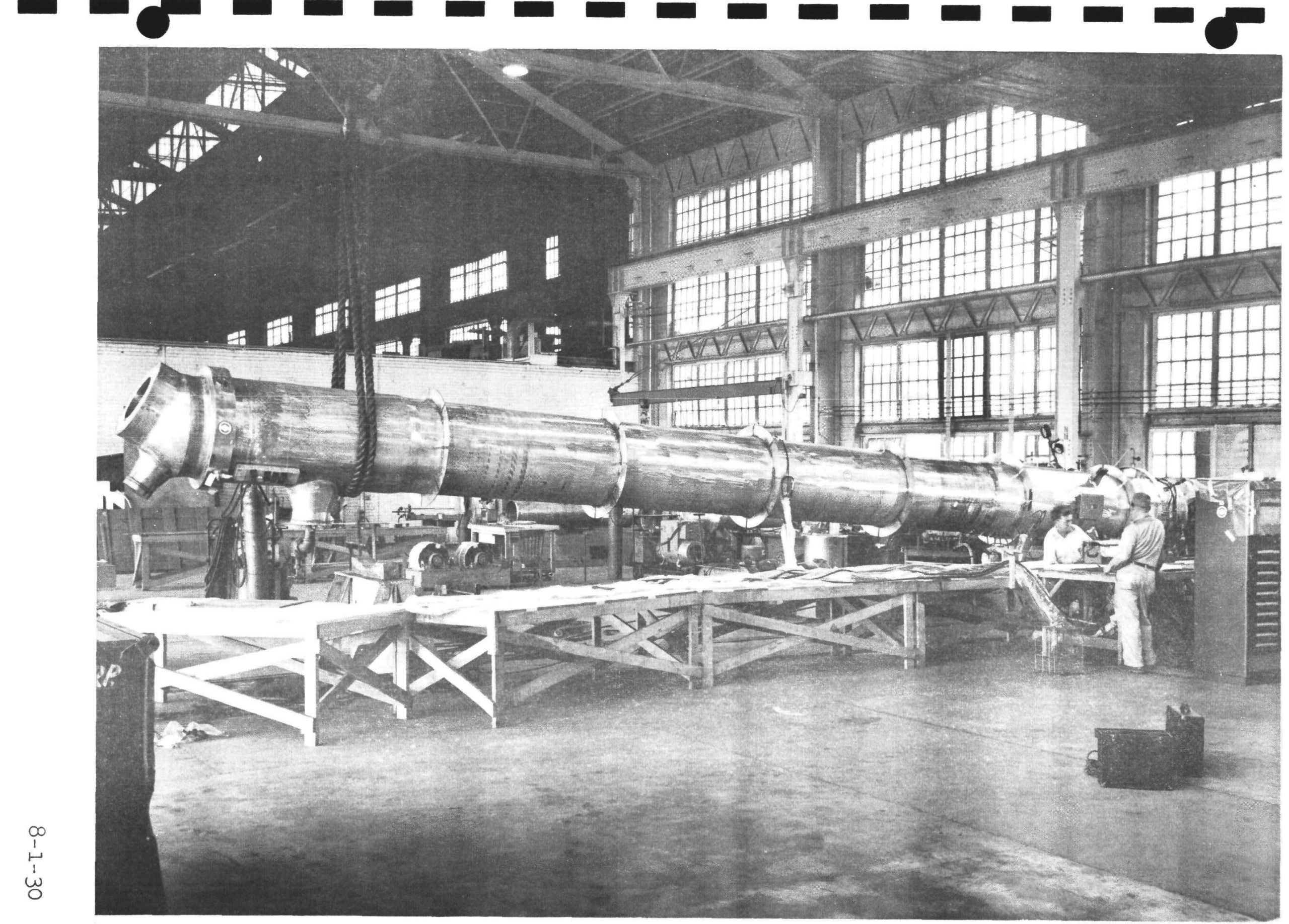

Shell raised at lower tube sheet end to vent air while filling with distilled water for hydrostatic pressure and strain gage tests. 


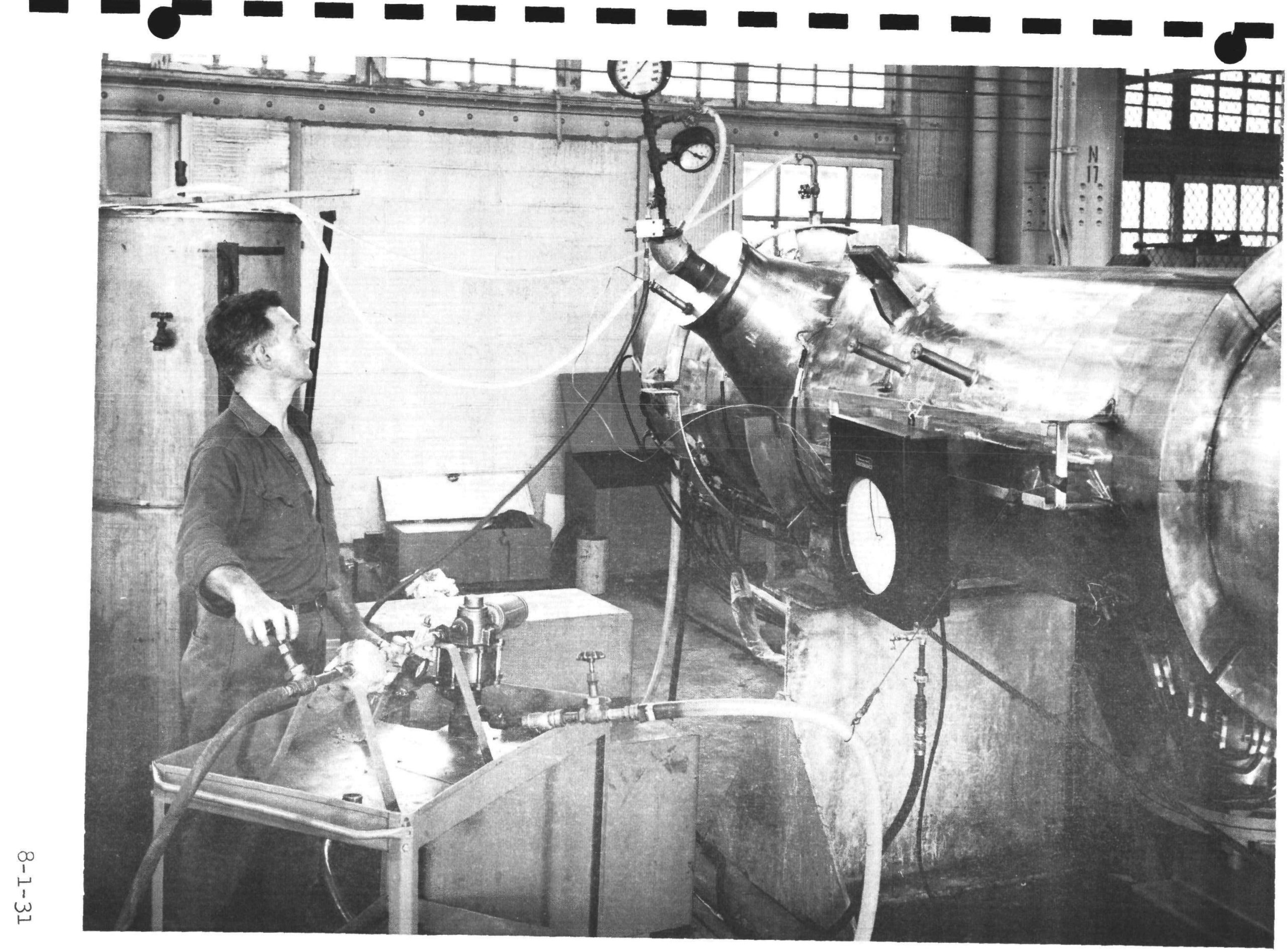

Pressurizing shell double pressure gages on nozzle and recording pressure gage on pedestal. 


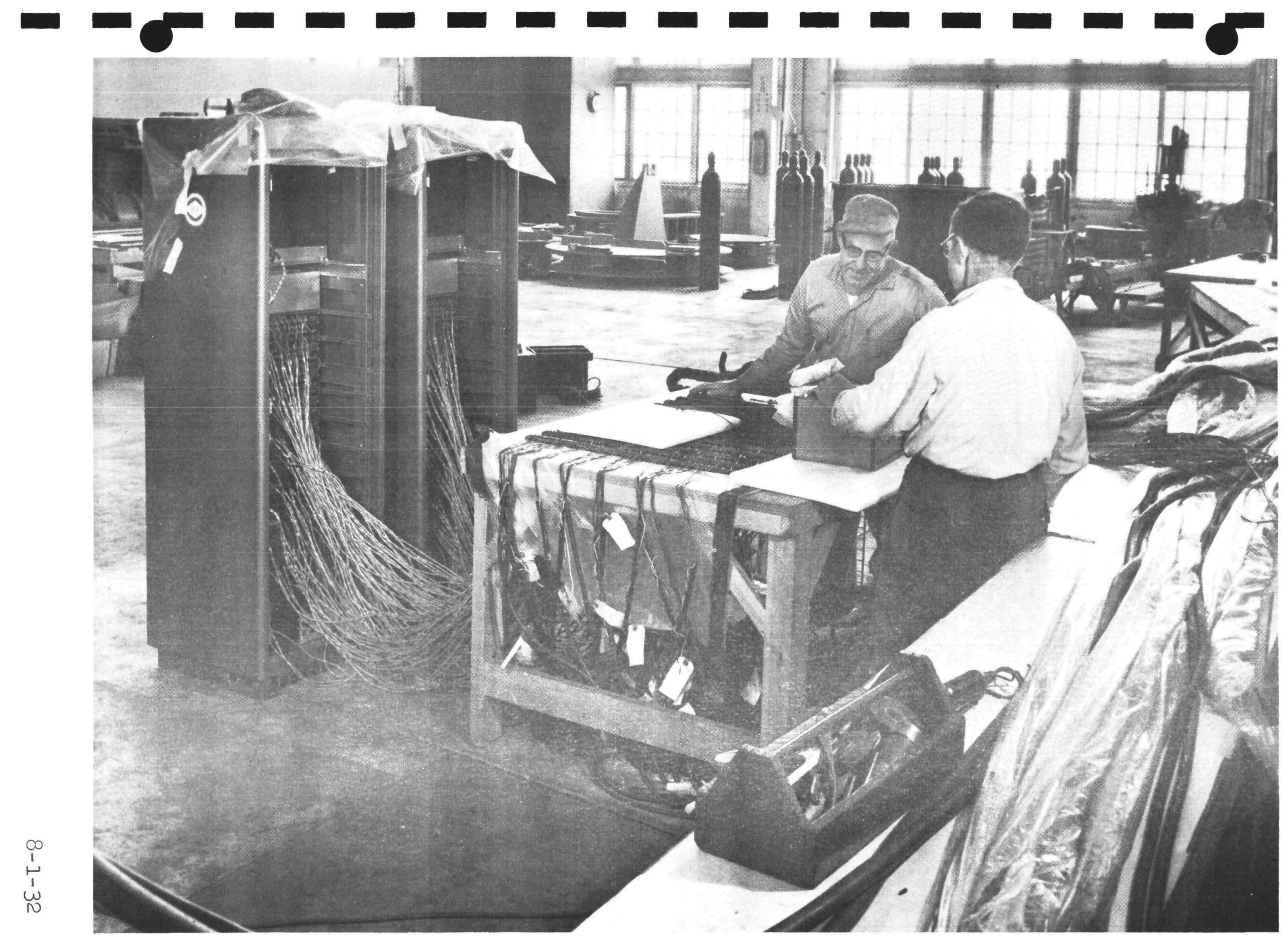

Connecting strain gages to terminal table and table to recorders at left. 


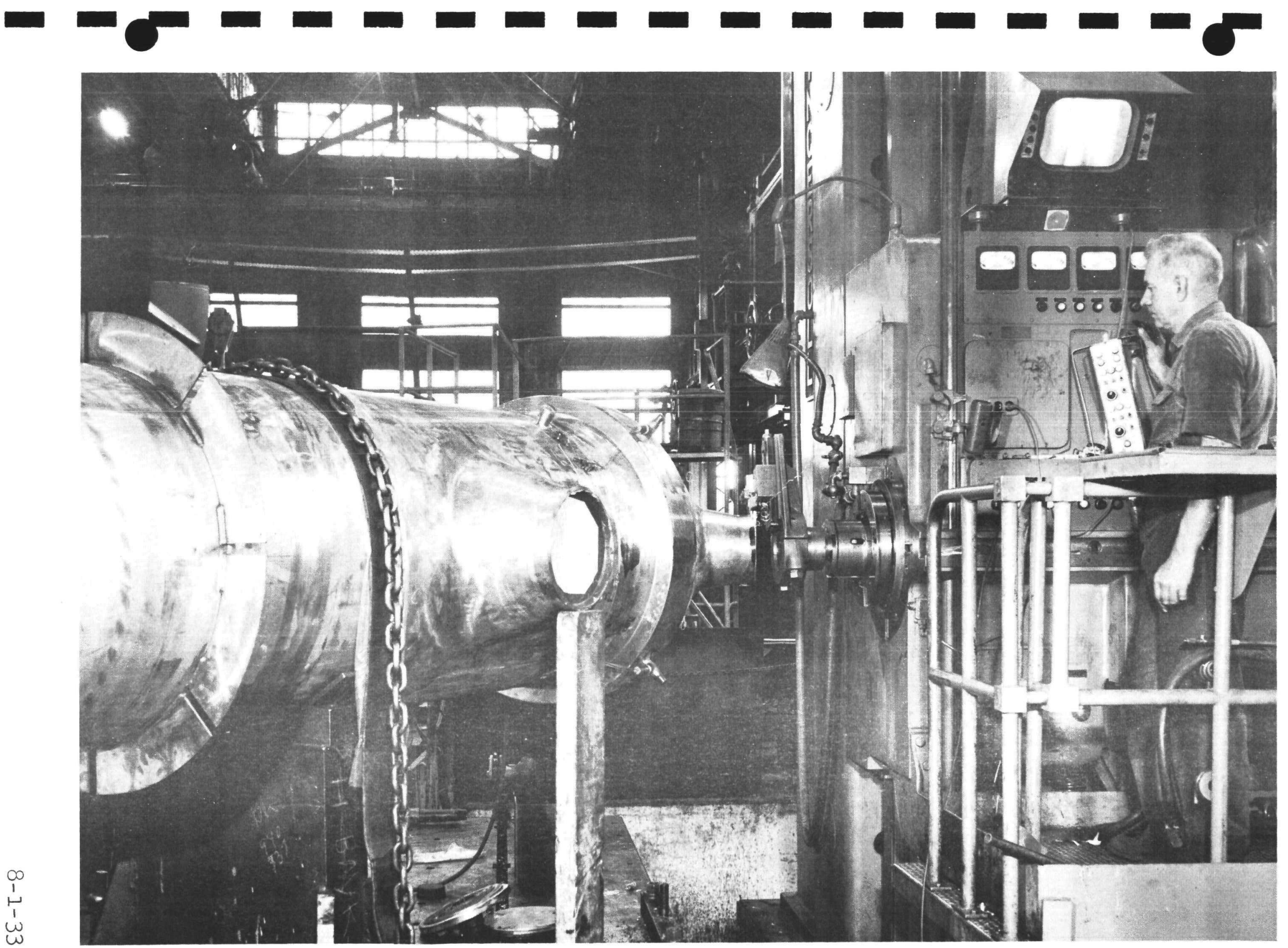

Machining off test covers and finishing weld kerf on water inlet nozzle after tests. 


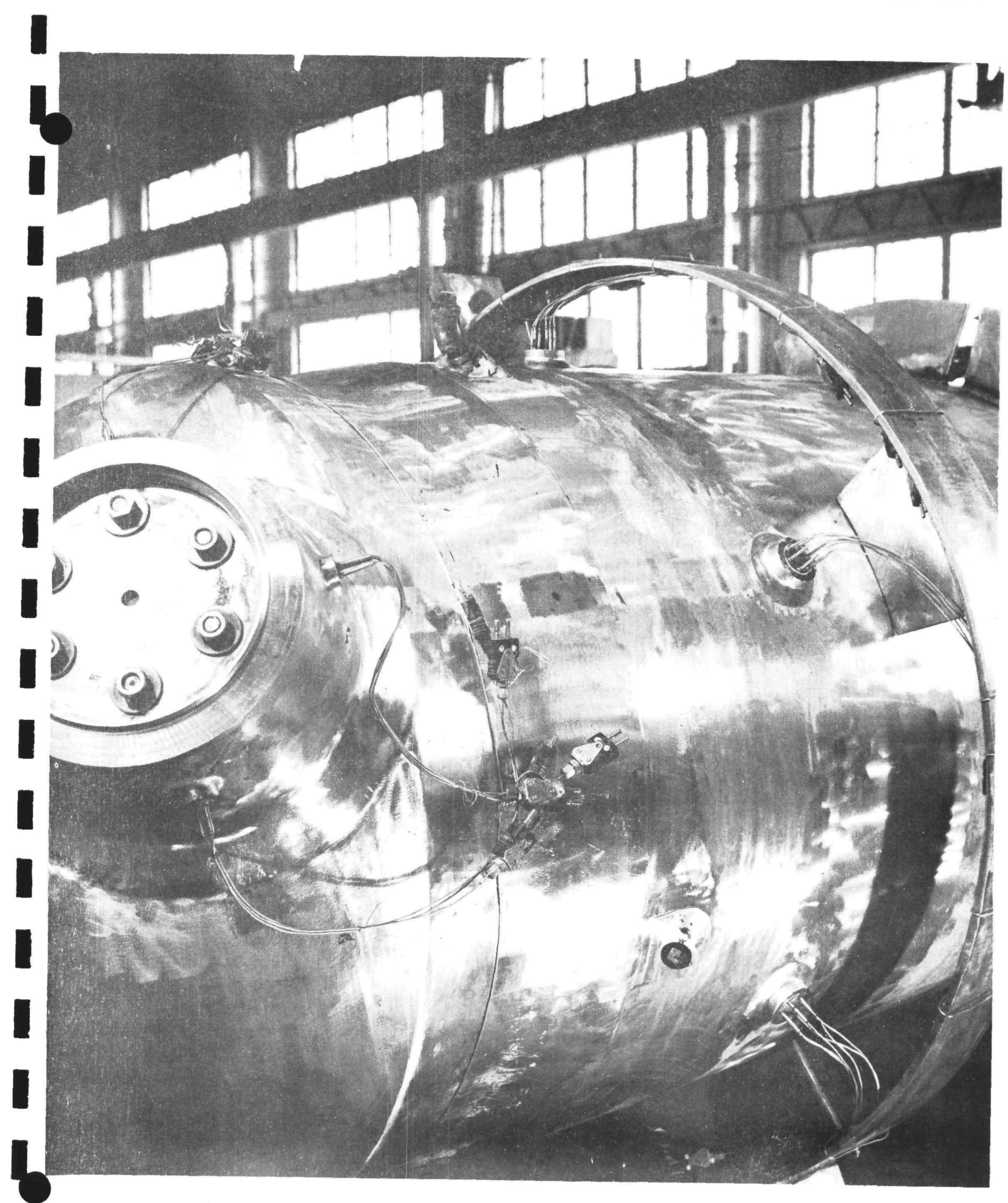

Upper head steam nozzle with expanded plug seal. Thermocouple wires wired to head and to a shipping ring to prevent breakage. 


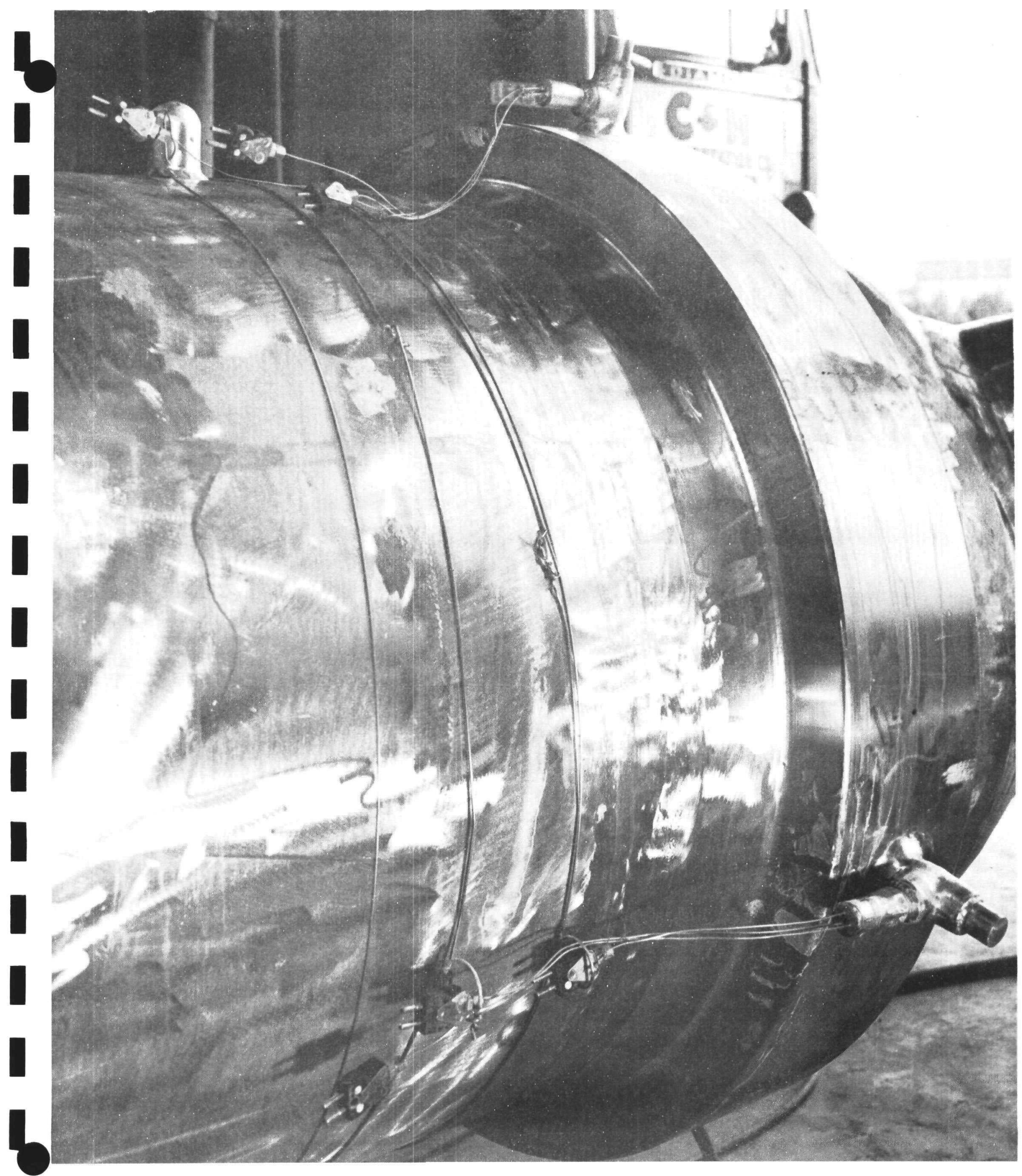

Lower tube sheet thermocouple wires wired to shell. 


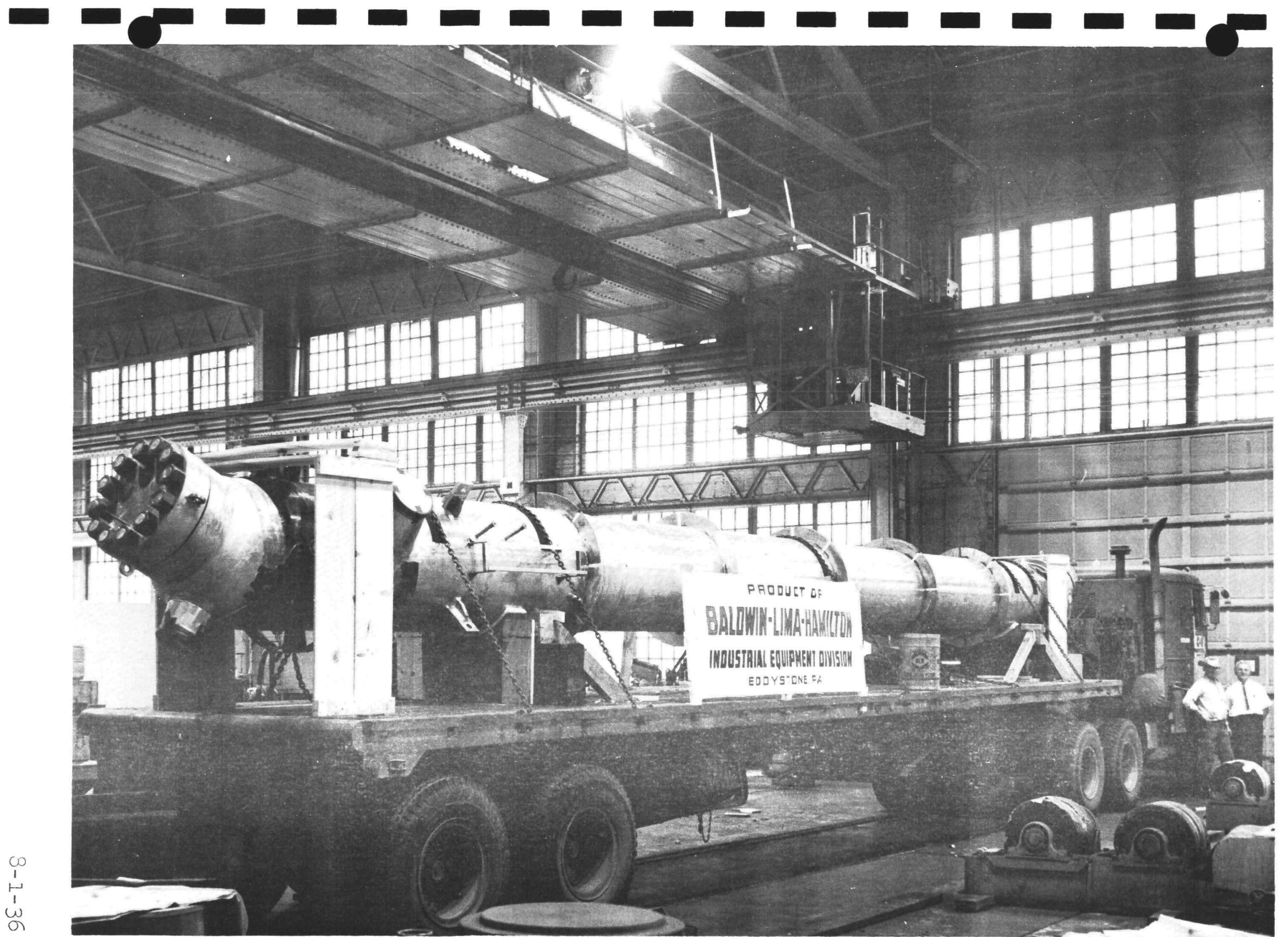

Unit mounted on truck with protective wooden structure at each end. 


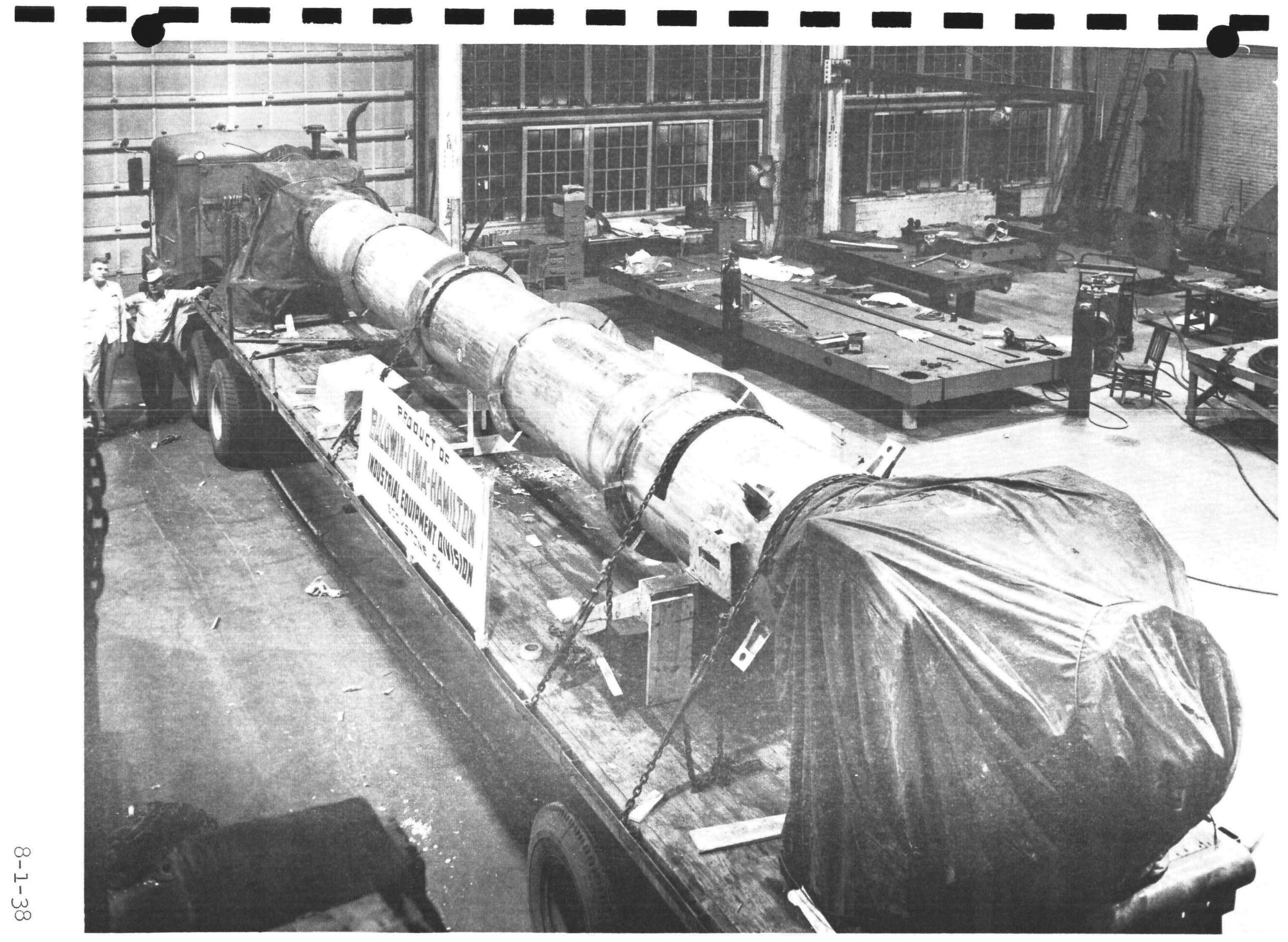

Tarpaulin covers at each end protect thermocouples. 